\title{
Research styles in virus studies in the twentieth century : controversies and the formation of consensus
}

Citation for published version (APA):

van Helvoort, A. A. F. J. (1993). Research styles in virus studies in the twentieth century : controversies and the formation of consensus. [Doctoral Thesis, Maastricht University]. Rijksuniversiteit Limburg. https://doi.org/10.26481/dis.19930402ah

Document status and date:

Published: 01/01/1993

DOI:

10.26481/dis.19930402ah

Document Version:

Publisher's PDF, also known as Version of record

Please check the document version of this publication:

- A submitted manuscript is the version of the article upon submission and before peer-review. There can be important differences between the submitted version and the official published version of record.

People interested in the research are advised to contact the author for the final version of the publication, or visit the DOI to the publisher's website.

- The final author version and the galley proof are versions of the publication after peer review.

- The final published version features the final layout of the paper including the volume, issue and page numbers.

Link to publication

\footnotetext{
General rights rights.

- You may freely distribute the URL identifying the publication in the public portal. please follow below link for the End User Agreement:

www.umlib.nl/taverne-license

Take down policy

If you believe that this document breaches copyright please contact us at:

repository@maastrichtuniversity.nl

providing details and we will investigate your claim.
}

Copyright and moral rights for the publications made accessible in the public portal are retained by the authors and/or other copyright owners and it is a condition of accessing publications that users recognise and abide by the legal requirements associated with these

- Users may download and print one copy of any publication from the public portal for the purpose of private study or research.

- You may not further distribute the material or use it for any profit-making activity or commercial gain

If the publication is distributed under the terms of Article $25 \mathrm{fa}$ of the Dutch Copyright Act, indicated by the "Taverne" license above, 
RESEARCH STYLES IN VIRUS STUDIES

IN THE TWENTIETH CENTURY

Controversies and the Formation of Consensus 


\section{RESEARCH STYLES IN VIRUS STUDIES IN THE TWENTIETH CENTURY \\ Controversies and the Formation of Consensus}

\section{PROEFSCHRIFT}

ter verkrijging van de graad van doctor

aan de Rijksuniversiteit Limburg te Maastricht, op gezag van de Rector Magnificus, Prof. Mr. M. J. Cohen, volgens het besluit van het College van Dekanen,

in het openbaar te verdedigen

op vrijdag, 2 april 1993 om 16.00 uur

door

Antonius Adrianus Franciscus Joseph van Helvoort geboren te Eindhoven 


\section{Promotor}

(Thesis advisor)

Prof. Dr. L. Boon, Rijksuniversiteit Limburg

\section{Co-promotor}

(Thesis co-advisor)

Dr. R. P. W. Visser, Rijksuniversiteit Utrecht

\section{Beoordelingscommissie}

(Examining board)

Prof. Dr. H. Beukers (voorzitter), Rijksuniversiteit Leiden

Prof. Dr. H. A. M. J. ten Have, Katholieke Universiteit Nijmegen

Prof. Dr. A. van Kammen, Landbouwuniversiteit Wageningen

Prof. Dr. J. van der Noordaa, Universiteit van Amsterdam

Dr. R. C. Olby, University of Leeds (United Kingdom) 
"Science is not just thinking or just theorizing. It also involves doing. Therefore, part of an epistemic style is the way in which scientific work is done at any given time for any given individual or group of individuals; and sometimes it is also localized in a given place. But it is more than that, too. An epistemic style involves commitments as to what one seeks as the outcome of science, as to what count as appropriate procedures for gathering knowledge, and as to how to know when one has achieved knowledge at all."

"In order to capture what is important in science we must cast our historical and philosophical nets more widely. Indeed, we must come to understand both the nature and significance not only of schools and traditions in science but also of styles, and in particular epistemic styles."

From Jane Maienschein, 'Epistemic Styles in German and American Embryology',

Science in Context, vol. 4 (1991), p. 410 \& p. 426, respectively (published November 1992).

\section{Cover illustration:}

Visual representation of the difference between multiplication of bacteria in a cell by binary fission (upper scheme) and the reproduction of viruses in a cell via its eclipse as an infectious entity (lower scheme). The recognition of this difference was fundamental for the establishment of virology as a separate scientific discipline.

Figure taken from F. Macfarlane Burnet, 'Virology as an Independent Science', Medical Journal of Australia, vol. 40 (1953), p. 842 


\section{Ton van Helvoort}

Department of Health Ethics and Philosophy

University of Limburg

P.O. Box 616

NL-6200 MD Maastricht, The Netherlands

Druk: Sneldruk, Enschede

(C) 1993, A. A. F. J, van Helvoort, Beek (L.), The Netherlands.

No part of the material protected by this copyright notice may be reproduced or utilized in any form or by any means, electronic or mechanical, including photocopying, recording or by any information storage and retrieval system, without written permission from the copyright owner. 


\section{PREFACE}

This dissertation is a compilation of papers which have recently been published in international journals or are in press. Perhaps this suggests that these articles are the result of research done during the last few years. However, this is not the case: the first studies included in this dissertation date from the first half of the 1980 s.

In 1982 I was awarded a one-year contract from the Ministry of Social Services and Employment (the so-called 'TAP-regeling') which was supervised by Dr. Willem Hornix, lecturer in the History of Chemistry at the Catholic University in Nijmegen, the Netherlands. Dr. Hornix and his colleagues of the project on 'The Development of the Dye Industries', Ernst Homburg and Henk van den Belt, were very helpful in formulating my first research problems. In the course of several years I was allowed to make use of the infrastructure and facilities of their project.

In addition, Prof. Peter Boskma ( $\dagger$ ) of 'De Boerderij' (at present the Department of Philosophy of Science and Technology) of the Technical University Twente was willing to support my first steps in the field of science studies. Dirk Stemerding, staff member at 'De Boerderij' and specialising in the history of biology, was also cooperative in reformulating my historical material so that it would fit mainstream science studies.

After the decease of Prof. Boskma in 1986, Prof. Louis Boon of the Department of Health Ethics \& Philosophy (HE\&P) of the University of Limburg offered me the opportunity to continue my studies on the history of virus research in a part-time function as researcher at that university. Within the Department of HE\&P Harry Smit in particular acted as a sounding board for my search for a theoretical framework for my historical studies, while Prof. Gerard de Vries from the Department of Philosophy also showed much interest. Prof. Paul Thung (HE\&P) went to great lengths to examine a large part of an early version of my dissertation. His critical comments were always an incentive to rethink what I had written or to revise it completely. 
Every article in this dissertation has gone through numerous versions. Therefore, I am much obliged to my advisor Prof. Louis Boon and co-advisor Dr. Rob Visser (Institute for the History of Science, University of Utrecht) for the energy with which they reviewed all those reformulations of the same basic material. Although they must at times have had their doubts about the feasibility of my undertaking, they continued to stimulate me.

I must also express my thanks to the (anonymous) referees of the journals to which I have sent my contributions. The effects of their comments and suggestions are not recognizable in the text, but I have used their help with gratitude.

Besides the gratitude I owe to those mentioned above for their support with regard to the contents of my research, many others have contributed more practically to the present dissertation. This is especially true of my colleagues at the Department of Health Ethics \& Philosophy, who have always shown great interest in the progress of my work. The secretaries of the department have always been very helpful in organisational matters. As will be clear from the documentation of the case-studies, I am also obliged to the staff of the university libraries in Nijmegen, Maastricht and especially Utrecht. Their customer-oriented services were always excellent.

The somewhat esoteric character of my study means that I am addressing myself largely to an international audience. It became clear at a very early stage that in the end the results of my study would, therefore, have to be published in English. As I found it too strenuous to write directly in English, I wrote each paper first in Dutch and translated it myself. Godelieve van Heteren and John O'Kane helped to correct Chapter 3 . The remaining chapters were competently revised by Jan Klerkx; his language intuition and his knowledge of the biomedical sciences preserved me from many mistakes. It goes without saying that all flaws which remain in the text are entirely my responsibility.

Last but not least, I want to thank Beatrice Dingemans for allowing me to complete this study. Although by now she knows how to interpret my claims that this or that paper or chapter was 'now really finished', I want to make one last attempt, with this book in hand, to convince her on this point.

Beek (Limburg), The Netherlands January 1993 
PREFACE $\mathbf{v}$

CONTENTS vii

CHAPTER 11

Research styles in virus studies in the twentieth century controversies and the formation of consensus: an introduction

1.1 Virology as an independent science 2

1.2 Filterable viruses 6

1.3 An antithesis in virus research $\mathbf{8}$

1.4 Research styles in virus studies $\mathbf{1 3}$

1.5 Research styles, controversies and continuity $\mathbf{1 6}$

1.6 The selection of case studies $\mathbf{1 8}$

\section{CHAPTER 221}

What is a virus? The case of tobacco mosaic disease

2.1 The discovery of a filterable agent $\mathbf{2 4}$

2.2 Early chemical and bacteriological studies 27

2.3 The isolation of tobacco mosaic virus $\mathbf{3 1}$

2.4 A physicochemical approach 34

2.5 A biochemical approach $\mathbf{3 9}$

2.6 TMV and the modern concept of virus 44

2.7 Diversity revisited $\mathbf{4 8}$

2.8 Conclusion: plurality of concepts $\mathbf{5 2}$

Adapted from

Studies in History and Philosophy of Science, vol. 22 (1991), pp. 557-588. 
CHAPTER $3 \quad \mathbf{5 7}$

A bacteriological paradigm in influenza research

in the first half of the twentieth century

3.1 Introduction: filterable viruses $\mathbf{5 8}$

3.2 Pfeiffer's bacillus $\mathbf{6 0}$

3.3 The influenza pandemic of $1918 \quad \mathbf{6 2}$

3.4 Filterable influenza virus $\mathbf{6 5}$

3.5 Manipulating the influenza virus $\mathbf{6 7}$

3.6 The bacteriological paradigm 69

3.7 Emancipation from the bacteriological paradigm $\quad 74$

Adapted from

History and Philosophy of the Life Sciences, vol. 15 (1993), in press.

\section{CHAPTER 477}

Bacteriological and physiological research styles in the early controversy on the nature of the bacteriophage phenomenon

4.1 'Discovery' of the bacteriophage phenomenon $\mathbf{8 1}$

4.2 Priority dispute and reification of bacteriophagy $\mathbf{8 4}$

4.3 D'Hérelle's interpretation further criticized $\mathbf{8 9}$

4.4 Félix d'Hérelle and the bacteriophage: a bacteriological style 93

4.5 Following in Louis Pasteur's footsteps 97

4.6 Jules Bordet, transmissible bacterial lysis and immunity $\mathbf{1 0 0}$

4.7 Jules Bordet and the bacteriophage: a physiological style $\mathbf{1 0 5}$

4.8 The constraining force of research styles $\mathbf{1 1 1}$

Adapted from

Medical History, vol. 36 (1992), pp. 243-270.

CHAPTER $5 \quad 115$

The controversy between John $H$. Northrop and Max Delbrück on the formation of bacteriophage: bacterial synthesis or autonomous multiplication?

5.1 Winner takes all $\mathbf{1 1 6}$

5.2. The study of bacteriophage in a chemical context 119

5.3. Northrop, bacteriophage, and the problem of protein synthesis $\mathbf{1 2 4}$

5.4. Delbrück, the 'Riddle of Life', and bacteriophage $\mathbf{1 2 8}$

5.5. Delbruick, bacteriophage, and the bacterium as a "black box" $\mathbf{1 3 3}$

5.6. Northrop and Krueger versus Delbrück in the early 1940 s 138

5.7. Northrop, Delbrück, and biochemistry in the late 1940s 142

5.8. Conclusion: clashing research styles $\mathbf{1 4 7}$

Adapted from

Annals of Science, vol. 49 (1992), pp. 545-575. 
CHAPTER $6 \quad 151$

The construction of bacteriophage as bacterial virus:

linking endogenous and exogenous thought styles

6. I Introduction $\mathbf{1 5 2}$

6.2 Attempts to link exogenous and endogenous thought styles 154

6.3 The 'modern concept of phage' $\mathbf{1 6 2}$

6.4 'Infectious heredity' revisited $\mathbf{1 7 0}$

6.5 Construction of bacteriophage as bacterial virus $\mathbf{1 7 4}$

Second part of an essay to be published in

Journal of the History of Biology, vol. 26 (1993), in press.

\section{CHAPTER $7 \quad 179$}

Controversies and the formation of consensus:

\section{conceptual continuity through discontinuity}

7.1 Research styles in virus studies $\mathbf{1 8 0}$

7.2 The concept of 'filterable virus': an anomaly to the bacteriological paradigm? 184

7.3 The deconstruction of the "unity" amongst filterable viruses 187

7.4 The construction of the domain of 'virus diseases' 191

7.5 The 'modern concept of virus': from multiplication to replication 198

7.6 The 'modern concept of virus' and the history of virology 203

7.7 Conceptual continuity through discontinuity 207

Adapted from

'History of virus research in the 20th century: the problem of conceptual continuity', History of Science, accepted for publication.

Samenvatting [Summary in Dutch] 213

Curriculum Vitae 223 
CHAPTER 1

Research Styles in Virus Studies in the Twentieth Century -

Controversies and the Formation of Consensus: An Introduction

CONTENTS

1.1 Virology as an independent science 2

1.2 Filterable viruses 6

1.3 An antithesis in virus research 8

1.4 Research styles in virus studies $\mathbf{1 3}$

1.5 Research styles, controversies and continuity $\mathbf{1 6}$

1.6 The selection of case studies $\mathbf{1 8}$ 


\section{CHAPTER 1}

\section{Research Styles in Virus Studies in the Twentieth Century - Controversies and the Formation of Consensus: An Introduction}

\subsection{VIROLOGY AS AN INDEPENDENT SCIENCE}

In the 1950 s and 1960 s the biomedical sciences saw a revolution which was characterized by one historian as The eighth day of creation. 'To a large extent this breakthrough took place as a result of the elucidation of the role of nucleic acid as the carrier of hereditary information and of the process by which this information is 'translated' in the synthesis of proteins. Institutionally, this led to the establishment of a new domain within science, viz. molecular biology. This branch of science was a hybrid of elements from different disciplines such as genetics, biochemistry, crystallography, bacteriology and virus research, and it soon gained great popularity. ${ }^{2}$ In turn these events were to be the prelude for the development of recombinant DNA techniques with which organisms could be genetically modified. ${ }^{3}$

Besides the molecular biologists-to-be, there was in the 1950s another group of researchers who claimed an independent domain for themselves: the virologists. While molecular biology was in fact a hybrid between many disciplines, virology in a certain sense occupied a scientific domain which can be seen to have a predecessor. In the 1930s many textbooks were published which addressed viruses and virus diseases but, for most investigators, the study of such diseases was only a part of their normal duties. In the 1930 s and 1940 s viruses were studied from the point of view of

1. H. F. Judson, The eighth day of creation: makers of the revolution in biology (London, 1979).

2. For the history of molecular biology see, for instance, also R. Olby, The path to the double helix (London, 1974); R. Olby, "The molecular revolution in biology", in R. C. Olby, G. N. Cantor, J. R. R. Christie and M. J. S. Hodge (eds), Companion to the history of modern science (London, 1990), pp. 503-20

3. For the bistory of the development of recombinant DNA technology see, for instance, J. D. Watson and J. Tooze, The DNA story: a documentary history of gene cloning (San Francisco, 1981); S. Krimsky, Genetic alchemy: the social history of the recombinant DNA controversy (Cambridge, Mass., 1982). 
pathology, bacteriology, immunology, serology, biochemistry, hygiene and epidemiology.

Around the middle of the 20th century important theoretical and social changes took place in virus research. These were reflected in the publication of books and the launching of several new periodicals which specifically centered upon virus research. In 1953 Salvador E. Luria's General virology was published, followed two years later by Macfarlane Burnet's Principles of animal virology. ${ }^{4}$ In 1939 the German Archiv für die gesamte Virusforschung (continued as Archives of virology) was started and for more than a decade this would be the sole journal which explicitly addressed viruses and virus diseases. The 1950 s showed a boom in the number of publications, initiated by the start of the annual serial Advances in virus research in 1953, and followed by new periodicals like Virology (1955), Voprosy virusologii [Problems in virology] (1956), Acta virologica (1957), Progress in medical virology (1958) and Perspectives in virology (1959).5 The establishment of institutes focussing on virus research gained momentum in the 1950s. In 1952 at the University of California in Berkeley, Wendell M. Stanley set up the "Virus Laboratory' which has since been named after him. Two years later, the 'Max-PlanckInstitut für Virusforschung' in 'Tübingen (Germany) was inaugurated. ${ }^{6}$

The establishment of virology as an independent discipline was based upon a new definition of viruses which was formulated in the 1950s. This 'modern concept of virus' rested on two assumptions. In the first place, that hereditary information of living organisms is encoded in nucleic acid, i.e. in the sequence of the building

4. S. E. Luria, General virology (New York, 1953); F. M. Burnet, Principles of animal virology (New York, 1955); F. M. Burnet and W. M. Stanley (eds), The viruses: biochemical, biological, and biophysical properties; Vol. I: general virology; Vol. II: plant and bacterial viruses; Vol. III: animal viruses (New York, 1959).

5. See "History and scope of virology", in R. Nicholas and D. Nicholas, Virology: an information profile (London, 1983), pp. 3-20. To a large extent, the exponential growth of the scientific enterprise after World War II certainly also contributed to the establishment of independent scientific disciplines in the 1950 s and 1960s. See, for instance, D. J. de Solla Price, Litlle science, big science ... and beyond (New York, 1986); J. Ben-David. Scientific growth: essays on the social organization and ethos of science, ed. G. Freudenthal (Berkeley, 1991).

6. See, for instance, H. L. Fraenkel-Conrat, "The impact of Wendell M. Stanley on the biochemical sciences", Welch Foundation conferences on chemical research, xx (1977), 253-61; A Butenandt, "The historical development of modern virus research in Germany, especially in the Kaiser-Wilhelm-Max-Planck-Society, 1936-1954", Medical microbiology and immunology, cixiv (1977), 3-14. 
blocks of nucleic acid, the nucleotides. Secondly, the claim that viruses reproduce in such a way that this can be used as a criterion to distinguish them from other microorganisms. Whereas micro-organisms (and cells in general) multiply by binary fission, it became accepted in the 1950s that viruses cannot grow but exclusively reproduce through their genetic material. It was assumed that, instead of undergoing a process of multiplication by growth and division, the virus particle passes through a so-called eclipse, that is to say, it temporarily disappears as an infectious entity.

The concept of virus which was formulated in the 1950s was in essence a definition in chemical terms. In 1957 André Lwoff, a member of the Institut Pasteur in Paris, proposed the following definition: "viruses are infectious, potentially pathogenic, nucleoproteinic entities possessing only one type of nucleic acid, which are reproduced from their genetic material, are unable to grow and to undergo binary fission, and are devoid of a Lipmann system." Because a virus could, on the basis of its infectivity, be distinguished from other genetic material, Lwoff concluded that "viruses should be considered as viruses because viruses are viruses."

Viruses can be considered as living entities because they have genetic continuity and undergo mutations. They show no intrinsic mobility, do not respond to stimuli and, as was stated above, do not grow in the same manner as other micro-organisms and cells of higher organisms. Because they lack a 'Lipmann system' which, in living cells, provides energy for growth and reproduction, viruses are dependent on the metabolic processes of their host cells. I will designate the definition of a virus described here as the 'modern concept of virus'. It formed the basis of the new classification on which virology became established:

$[T]$ he mechanism by which viruses reproduce is unique in biology. This seems to be true whether one is talking about a virus of green plants, bacteria, mushrooms, algae, insects, higher animals, or humans. In all cases, during the reproductive cycle the genetic material of the virus becomes a functional part of the cell it has infected. The genes added to the cell by the virus cause the infected cell either to produce more virus particles, with cell death usually the end result, or to become changed and acquire new characteristics. ${ }^{8}$

7. A. Lwoff, "The concept of virus: the third Marjory Stephenson memorial lecture", Journal of general microbiology, xvii (1957), 239-53, esp. p. 246 and p. 252, respectively. A 'Lipmann system' for the formation of peptide bonds can be defined as an integrated oxidation-reduction system consisting of enzymes (conjugated proteins in the oxidized or reduced state) that, in turn, react with specific electron donors and electron acceptors, with free energy being released at every step of the electron transport. For a recent exposé on viruses see, for instance, A. J. Levine, Viruses (New York, 1992). 
The mechanism by which a virus is reproduced was claimed to be independent of the type of organism which it had infected and was described as genetic parasitism at the cost of the integrity of the host cell. The concept of virus which was formulated in the 1950 s provided a basis for classifying a large number of agents which infected a wide variety of cells (bacteria, cells of plants or animals) as belonging to only one category. This gave virus researchers an important argument to claim an independent status for their research field, thus emancipating virology from bacteriology. 9

However, the 'modern concept of virus' contained yet another element which was to extend the area of consensus. The above quotation shows that a virus infection can proceed in two directions. In the first option, it can result in replication of the virus and, more often than not, death of the infected host cell. In the second process, the virus is not reproduced, but the genetic information of the virus is incorporated into the cell, modifying certain properties of the latter. Experimental evidence for the thesis that a virus infection can follow this mechanism was obtained particularly from the study of bacterial viruses (bacteriophages). If the genetic information of a bacterial virus is incorporated in a bacterium, a so-called 'lysogenic' bacterium results, i.e. a bacterium which is able to multiply while the bacteriophage cannot be shown to be present. However, under certain circumstances the bacteriophage can be induced and is then produced, under lysis of the bacterial host cell. The 'built-in' genetic information of the bacterial virus is named probacteriophage (or prophage) and it has been shown that this incorporation changes some of the characteristics of the (lysogenic) bacterium. The lysogenic bacterium and the prophage would become a model for the phenomena of 'virus masking' and 'latent viruses', which were observed, but not understood, in the 1930 s and 1940s. The mechanism of lysogeny was to become an important metaphor in the study of cell-transformation by oncogenic viruses. Thus, the 'modern concept of virus' not only unified infectious diseases in bacteria, plants and animals but also brought in cancer under the same heading. ${ }^{10}$

8. C. R. Goodheart, An introduction to virology (Philadelphia, 1969), p. 1; cited in S. S. Hughes, The virus: a history of the concept (London, 1977), p. ix.

9. See, for instance, F. M. Burnet, "Mathison memorial lectures: virology as an independent science", Medical journal of Australia, xl (1953), 841-5. For the history of virus research see, for instance, R. Doert, "Die Entwicklung der Virusforschung und ihre Problematik", in R. Doerr and C. Hallauer (eds), Handbuch der Virusforschung (Vienna, 1938), pp. 1-125; F. M. Burnet, "An historical introduction to animal virology", in Burnet, op. cit. (ref. 4), pp. 1-32; Hughes, op. cit. (ref. 8); A. P. Waterson and L. Wilkinson, An introduction to the history of virology (Cambridge, 1978).

10. Burnet and Stanley, op. cit. (ref. 4); L. Gross, Oncogenic viruses (Oxford, 1961). 
The institutionalisation of virology was founded on these insights and in the 1950 s the 'modern concept of virus' transformed not only the concept of 'virus' but also the conceptions of 'life' and 'cancer'.

\subsection{FILTERABLE VIRUSES}

When virology was institutionalised in the 1950s this new discipline, unlike molecular biology, had a predecessor. Not in the sense that there was a specific professional group in the first half of the 20th century, but in the cognitive sense that there had been a category of 'filterable viruses'. Broadly speaking it can be claimed that those infectious agents which are currently classified as viruses used to be designated as the filterable viruses, a point of view which is normally defended in the historiography of virology.

In 1892 it was reported for the first time that an infectious agent could pass through ultrafilters which were thought to be impervious to bacteria. This agent, causing mosaic disease in tobacco plants, would soon be named tobacco mosaic virus. Around the turn of the century, other infectious agents, like those of foot-and-mouth disease and yellow fever, were also found to be ultrafilterable. The infectious diseases for which filterability of the etiological agent was observed involved plants as well as animals. In a short time, many reviews were published on this particular subject, designating them as 'filterable' or 'invisible' viruses. ${ }^{11}$ The adjective filterable was added as a consequence of the 19th century convention to designate all infectious agents as 'viruses', including, e.g., protozoa and bacteria. ${ }^{12}$

In 1917 the term 'bacteriophage' was proposed for a filterable lytic principle which seemed to multiply at the cost of bacteria. When bacteriophage was added to a fresh bacterial culture the bacteria were found to be lysed (dissolved) after a short time,

11. See, for instance, E. Roux, "Sur les microbes dits 'invisibles'", Bulletin de l'Institut Pasteur, i (1903), 7-12 and 49-56; P. Remlinger, "Les microbes filtrants", idem, iv (1906), 337-45 and 385-92; J. M'Fadyean, "The ultravisible viruses", Journal of comparative pathology and therapeutics, xxi (1908), 58-68, 168-75 and 232-242; S. B. Wolbach, "The filterable viruses, a summary", Joumal of medical research (N.S.), xxvii (1912), I-25.

12. For the history of bacteriology see, for instance, W. Bulloch, The history of bacteriology (New York, 1938, repr. 1979); W. W. Ford, Bacteriology (New York, 1939); R. N. Doetsch (ed.), Microbiology: historical contributions from 1776 to 1908 (New Brunswick, N. J., 1960); T. D. Brock (ed.), Milestones in microbiology (Englewood Cliffs, N. J., 1961); W. D. Foster, A history of medical bacteriology and immunology (London, 1970); H. A. Lechevalier and M. Solotorovsky, Three centuries of microbiology (New York, 1965, repr. 1974); P. Collard, The development of microbiology (Cambridge, 1976). 
while the bacteriophage had multiplied. Félix d'Hérelle, who coined the name for this principle, was convinced that bacteriophage was a virus of the bacterium, a point of view which was heavily criticised. For those who interpreted bacteriophage as a bacterial virus the category of 'filterable viruses' contained infectious agents with three different types of organisms as hosts: animals, plants and bacteria. An example of a textbook with such a classification is the book Filterable viruses, published in 1928 and edited by Thomas M. Rivers, which included a chapter on bacteriophage. However, Rivers' inclusion of bacteriophage in a book on viruses was to be criticised, especially by virus researchers from England. ${ }^{13}$

In general, the size of the infectious agents, as indicated either by their filterability or by their microscopical invisibility, was used as an operational criterion to delineate the research domain of the filterable infectious agents. Some interpreted the dependence of the multiplication of a filterable virus on a host cell as a specific property of the filterable viruses, but others regarded this as a mere technical problem. The latter were convinced that with further development of the experimental methods and the knowledge of the filterable viruses it would, in the end, be possible to cultivate these agents on lifeless inert nutrient media. However, Thomas M. Rivers held the opinion that this non-cultivability was a fundamental characteristic of the filterable viruses. In 1932 he suggested that viruses were characterized "by three negative properties, namely, invisibility by ordinary microscopic methods, failure to be retained by filters impervious to well-known bacteria, and inability to propagate themselves in the absence of susceptible cells." 14 But Rivers' definition did certainly not meet with general consensus.

With the concept of 'filterable viruses', a category of infectious agents was claimed to exist which could be distinguished from other infectious agents and at the same time shared a common property among themselves. In the 1920s and 1930 s research on the nature of the filterable viruses argued against the classification of bacterial, plant and animal viruses as one category. The filterable viruses infecting animals, plants or bacteria appeared to consist of a highly heterogeneous set of agents. Physicochemical and biochemical research led to the conclusion that filterable viruses infecting animal

13. T. M. Rivers (ed.), Filterable viruses (London, 1928); S. Benison, Tom Rivers: reflections on a life in medicine and science (Cambridge, Mass., 1967), p. 438.

14. T. M. Rivers, "The nature of viruses", Physiological reviews, xii (1932), 423-52, esp. p. 423. This definition makes it clear that the concept of the 'filterable virus' originated in anomalies observed with respect to the bacteriological paradigm. Besides these three negative properties, the filterable viruses were of course characterised by a positive one, viz. infectivity. 
cells were much more complex than plant viruses. The crystallisation of tobacco mosaic virus (TMV) in 1935 by Wendell M. Stanley constituted a weighty argument for considering this virus as a chemical (macro)molecule. Initially, Stanley thought he was dealing with a pure protein, but later he recognized the presence of nucleic acid in his preparations. TMV and many other plant viruses could be purified with physicochemical methods and appeared to be nucleoproteins. In the electrophoresis apparatus and the ultracentrifuge these viruses behaved as molecules. On the other hand, viruses infecting animals were found to be much more complex and to contain, in addition to proteins, lipids and antigenic components originating from the host cell. Although in the 1930 s consensus was achieved that filterable viruses were metabolically inert, it was claimed in the early 1940 s that at least some of the animal viruses possessed enzymatic activity.

Generally, those who studied animal viruses concluded that a virus could best be viewed as an ultramicrobe, as a "midget of the microbial world", a view which was inspired by an analogy with bacteriology. However, useful metaphors for the nature of plant and bacterial viruses were suggested by many other disciplines, such as physical chemistry (suggesting a macromolecular nature) and biochemistry and physiology (seeing them as endogenous chemical products of the host cell). The theory of heredity was also a source of inspiration for interpretations and in the early 1920 s it was suggested that TMV could be a particle of chromatin or a gene, and similar ideas were also proposed for the nature of bacteriophage.

During the first half of the 20th century the research on (filterable) viruses was thus characterized by a proliferation of interpretations concerning the nature of these agents. ${ }^{15}$ This conclusion emphasizes the power of the 'modern concept of virus' to unify these various notions in the 1950 s and to stimulate consensus.

\subsection{AN ANTITHESIS IN VIRUS RESEARCH}

In the 1930s and 1940s many suggestions were made about the nature of 'viruses', which eventually led to the deconstruction of the concept of the 'filterable virus'. An important change was that many researchers began to interpret bacteriophage not as a bacterial virus but as a product of the bacterium. As will be apparent from the case studies to be discussed in the next chapters, the interpretations of the nature of viruses

15. In the rest of this study I will often use the term 'virus' although the use of the term. 'filterable virus' was current far into the 1930s. Therefore, it should be noted that I always use the term 'virus' in the narrower sense (unless otherwise indicated) and not in the broad sense of every infectious agent, as was usual around the turn of the century. 
can be divided into two opposing notions. According to the first interpretation a virus was an exogenous and autonomous agent, which was confronted by the notion that a virus was a product of the host cell, i.e. an endogenous product.

The exogenous interpretation was a direct consequence of the context in which the filterable viruses were discovered, viz, as an anomaly (filterability) with regard to the contemporary bacteriological paradigm at the end of the 19 th century. In the first two decades of the twentieth century, the view that filterable viruses were ultramicrobes was the most popular, both for viruses infecting animals and for those infecting plants. The acceptation of the ultramicrobial (organismal) nature of viruses resulted in a number of important presuppositions with regard to the behaviour of the viruses. First, it was thought probable that viruses multiplied in the same way as bacteria do, viz. by a process of binary fission. A second assumption concerned the relationship between viruses and the cells they infected. As was stated above, many researchers took it for granted that the non-cultivability of viruses on inert media was only a technical problem, which would be solved as more knowledge was gained in this new field of study.

Culturing bacteria on inert media had been very advantageous for the development of bacteriology, especially since solid nutrient media had made it possible to isolate bacteria in pure culture. ${ }^{16}$ It was known that certain bacteria could only be grown in the presence of specific growth factors. For instance, the bacterium Haemophilus influenzae, discovered in 1892, depended for its growth on the presence of hemoglobin in the medium (see Chapter 3). Therefore, it seemed plausible to accept that a filterable virus was to be characterized as an ultramicrobe which depended on the host cell because the latter supplied the virus with one or more substances necessary for its growth. If these growth factors could be identified, it would become possible to culture filterable viruses on inert nutrient media by adding these substances. It will be clear that the 'modern concept of virus' described earlier denied precisely these two presuppositions, i.e. virus multiplication by binary fission and dependence on the host cell only because of the lack of certain growth factors.

The exogenous conception of the nature of viruses came to be opposed by an endogenous notion which claimed a virus to be a product of the infected cell. This notion had many adherents, especially among those who studied the bacteriophage

16. For the technical aspects of these bacteriological methods see, for instance, R. Koch, "Zur Untersuchung von pathogenen Organismen", Mittheilungen aus dern Kaiserlichen Gesundheitsamte, i (1881), 1-48. Cf. T. D. Brock, Robert Koch: a life in medicine and bacteriology (Madison, WI, 1988). 
phenomenon. It should be added at once that most of those who conceived of bacteriophage as a product of the bacterium did not classify it as a virus.

The endogenous interpretation of the bacteriophage phenomenon had marked repercussions for virus research in general, as is apparent from the following quotation from the Dutch bacteriologist Paul C. Flu in 1940:

In none of the great handbooks or monographs published before 1920 does one find another notion of the nature of the virus [than that of a living entity]. If now and then a deviant opinion was voiced, critics were only too eager to contest this forcefully. After 1920 a surprising change is to be noted in the views of a large number of microbiologists, including some of the leading figures. The numbers of those who, with hindsight, want to see every virus, or at least some types, as non-living, as unorganised and as a product of the living cell, are increasing. The reason for this change has to be sought, at least to a large extent, in a remarkable discovery, viz. that of the bacteriophage, by d'Hérelle. ${ }^{17}$ [My translation.]

The endogenous interpretation of the nature of viruses was suggested from a physiological or biochemical context and was especially popular within bacteriophage research and less so in the research of plant viruses. According to the endogenous notion, virus production was caused by a disturbance of the metabolism of the host cell and the virus had to be conceived of as a lifeless product. For such a lifeless and chemical principle there were also models and analogies available which could explain the 'multiplication' of the agent. In this case researchers thought in terms of autocatalytical processes known from physiology, but comparisons were also made with the growth of crystals.

The case studies in Chapters 2-6 will show that for half a century, the antithesis between exogenous and endogenous interpretations played an important part in virus research. However, this dichotomy is too superficial a subdivision, because the exogenous interpretation of the nature of a virus can be divided further into a number of notions derived from different disciplines, which have already been mentioned. Within the first approach viruses were regarded as ultramicrobes. This notion had the largest number of adherents, but some emphasized other characteristics and studied viruses either by genetic methods or from an ecological point of view. In contrast to these organismal notions, there was within the exogenous conception yet another approach, which was inspired by the crystallisation of tobacco mosaic virus and was mainly restricted to the research on plant viruses. This physicochemical approach

17. P. C. Flu, "Een facet van het virusprobleem", Acta Leidensia scholae medicinae tropicae, $x \vee(1940), 1-24$, esp. p. 9. 
combined the notion of a virus being exogenous and autonomous with the notion of a virus as a precisely defined chemical (macro)molecule. As in the endogenous interpretation of a virus, the models of autocatalysis and crystal growth were central in the exogenous physicochemical interpretation of the 'multiplication' of (lifeless?) viruses. Thus, I hope to show in this study that virus research in the first half of the 20 th century can be divided into an exogenous approach, within which physicochemical, bacteriological, genetic and ecological research styles can be distinguished, and endogenous approaches.

It will be clear from my terminology that these various interpretations of the nature of viruses were associated with the disciplinary backgrounds of the researchers involved. In 1952 Christopher H. Andrewes, a British researcher of animal viruses, expressed this relationship as follows:

It is my experience that those who have studied viruses from the widest point of view, including not only their intrinsic properties but their reactions with the cell they infect and the host they infect, are more apt to consider them as organisms while others who have looked at them from perhaps a more restricted point of view - chemists, physicists, geneticists - are more apt to toy with other hypotheses. 18

The disciplinary angles from which the virus problem was approached played a role not only in the interpretation of the results but also in the choice of experimental techniques, the research objects used, etcetera. In my analysis of virus research in the 20 th century it is assumed that the experimental techniques, experiments and theories are all interwoven and together make up a particular approach. To express this interrelatedness I use the term research style. ${ }^{19}$

This view is related to the Duhem-Quine thesis, according to which a scientist can never subject an isolated hypothesis to experimental test, but only a whole group of hypotheses. Pierre Duhem argued that the physicists' predictions are not based on any single hypothesis but, instead, on several or even many assumptions and rules of inference. These are, for instance, inherent in the use of scientific apparatus and

18. C. H. Andrewes, "Viruses as organisms", in Poliomyelitis: papers and discussions presented at the second international poliomyelitis conference (Philadelphia, 1952), pp. 3-5, esp. p. 3.

19. The terms of 'paradigm' and 'disciplinary matrix', introduced by Thomas S. Kuhn, are attempts to express the interrelatedness of theory and experiment. See, for instance, T. S. Kuhn, The structure of scientific revolutions, 2 nd edn, (Chicago, 1970); T. S. Kuhn, The essential tension: selected studies in scientific tradition and change (Chicago, 1977). 
techniques. Willard V. O. Quine's thesis, which is more radical than Duhem's, claims that any statement can be held true if sufficiently drastic adjustments are made elsewhere in the system. Quine stated that only science as a whole was empirically testable, which leads to a holistic view of science. ${ }^{20}$

In this study an analysis is made of the processes by which the various interpretations of viruses were construed. Because concepts, theories and experiments must be seen as belonging to a holistic scientific view (viz. a research style), a basic assumption in this study will be that an experiment never merely confronts a theoretical statement with nature but always intertwines it with other theoretical presuppositions. This links my study to the current interest of philosophers and sociologists of science in the role of experiment. On the basis of the Duhem-Quine thesis, Timothy Lenoir rightly concluded that an "experiment is simply theory conducted by other means". ${ }^{21}$

The multiplicity of hypotheses proposed in relation to the nature of viruses in the first half of the 20th century, and the controversies which arose, constitute a first theme in the present study. The way in which consensus was reached between these conflicting interpretations in the 1950 s is the second central topic. A third issue of this study concerns the relation between the impression of conceptual continuity on the one hand and the discontinuous development of the two distinct virus concepts formulated since the last decade of the 19 th century on the other. That is to say, the formation of the concept of the 'filterable virus', the deconstruction of this concept and, subsequently, the acceptation of the 'modern concept of virus'. In other words: by what mechanisms was conceptual continuity which can be recognized in virus research when, at the same time, there were so many diverging research styles and,

20. See P. Duhem, La théorie physique: son objet et sa structure (Paris, 1906) translated as The aim and structure of physical theory (Princeton, 1954); W. V. O. Quine, From a logical point of view (Cambridge, Mass., 1953). See also the collection of essays by philosophers and historians of science in S. G. Harding (ed.), Can theories be refuted? Essays on the Duhem-Quine thesis (Dordrecht, 1976).

21. T. Lenoir, "Practice, reason, context: the dialogue between theory and experiment", Science in context, ii (1988), 3-22, esp. p. 4. The interest in 'experiments' as a topic in historical studies of science is evident from the voluminous literature over the last decade. See, for instance, G. N. Gilbert and M. Mulkay, "Experiments are the key: participants' histories and historians' histories of science", Isis, Ixxv (1984), 105-25; D. Batens and J. P. van Bendegem (eds), Theory and experiment: recent insights and new perspectives on their relation (Dordrecht, 1988); J. L. Sturchio (ed.), "A special issue on artifact and experiment", Isis, lxxix (1988), 369-476: D. Gooding, T. Pinch and S. Schaffer (eds). The uses of experiment: studies in the natural sciences (Cambridge, 1989). 
consequently, so many controversies?

\subsection{RESEARCH STYLES IN VIRUS STUDIES}

The various interpretations of the nature of viruses were to a large extent influenced by the disciplinary backgrounds of the researchers. The importance of these disciplinary contexts is related to the theme of 'conservation and innovation' which is central to the work of Thomas S. Kuhn. This historian of science expressed the dilemma between conservation of accepted knowledge and the claims of new knowledge as the essential tension within scientific research: "only investigations firmly rooted in the contemporary scientific tradition are likely to break that tradition and give rise to a new one." If the interpretation of a new observation is to be successful, i.e. accepted by the scientific community, the new knowledge claim has to be interpreted in terms of accepted knowledge, that is to say, existing disciplines. ${ }^{22}$ For instance, the filterability of a particular infectious agent which was observed at the turn of the century was generally interpreted from the point of view of the most relevant discipline, i.e. bacteriology. An exception was the concept formulated by Martinus W. Beijerinck for tobacco mosaic virus, which he described as a contagium vivum fluidum (see Chapter 2). This linking of the idea of a living agent with the concept of 'fluidity' was regarded as too revolutionary and fell on deaf ears. However, with the 'modern concept of virus' as accepted knowledge, Beijerinck's hypothesis can be interpreted as an important precursor, since it regarded a virus as different from other micro-organisms.

A whole gamut of terms is available to describe a domain of existing knowledge, such as discipline, domain, field, paradigm or 'specialty'. With regard to the activities of researchers in such domains, terms like research programme, research school or research style are useful. ${ }^{23}$ In this study I will designate the complex of theoretical

22. T. S. Kuhn, "The essential tension: tradition and innovation in scientific research", in Kuhn (1977), op. cit. (ref. 19), pp. 225-39, esp. p. 227. In Fleck's comparative epistemology the concept of 'thought style', with the affiliated concept of 'thought constraint', represents another attempt to describe the conservation of knowledge. For the work of Ludwik Fleck see T. J. Trenn and R. K. Merton (eds), Ludwik Fleck: genesis and development of a scienific fact (Chicago, 1979); L. Fleck. Entstehung und Entwicklung einer wissenschaftlichen Tatsache (Frankfurt am Main, 1980); L. Schäfer and T. Schnelle (eds), Ludwik Fleck: Erfahrung und Tatsache (Frankfurt am Main, 1983); R. $\mathrm{S}$. Cohen and T. Schnelle (eds), Cognition and fact: materials on Ludwik Fleck (Dordrecht, 1986). In his 'Empirical programme of relativism' Harry Collins also emphasized that most old knowledge has to be conserved if new knowledge is to be accepted. See H. M. Collins. Changing order: replication and induction in scientific practice (London, 1985), p. 132. 
notions and experimental techniques of a virus researcher by the concept of 'style' or 'approach', terms which are intended to be interchangeable.

Following Alistair C. Crombie, Ian Hacking proposed the idea of a 'style of reasoning', of which he distinguishes the following forms: "(a) the simple postulation and deduction in the mathematical sciences, (b) experimental exploration, (c) hypothetical construction of models by analogy, (d) ordering of variety by comparison and taxonomy, (e) statistical analysis of regularities of populations, and ( $f$ ) historical derivation of genetic development". ${ }^{24}$ Louis Boon's study De list der wetenschap ["The cunning of science"] uses the concept of methodological style. Illustrated by the discovery of the structure of DNA in the early 1950s, it is argued in his study that there are two competing methodological styles. Rosalind Franklin worked along a direct, empirical approach, which was strongly influenced by the work of John D. Bernal. In this inductive approach, the application of X-ray diffraction was used to elucidate the structure of DNA. On the other hand there were Francis Crick and James D. Watson, who worked along deductive lines in which priority was given to speculative theorizing, the use of models and the derivation of testable statements. ${ }^{25}$

However, the research styles I describe in this study are not methodological styles but a combination of styles (b) and (c) in the classification by Crombie and Hacking. The different styles I have distinguished in virus research did not originate in different rational methods but as a result of different analogies and different models which were felt to be relevant. Emphasizing the holistic character of scientific knowledge it has to be stressed that each approach gave rise to a specific conceptual network, which must be analysed in its totality. These networks resulted in the study of research objects from different angles, using different experimental techniques, but also led to

23. With regard to research schools and research styles see, for instance, S. R. Mikulinskij, M. G. Jarosevskij, G. Kröber and H. Steiner (eds), Wissenschaftliche Schulen; Band I (Berlin, 1977); G. L. Geison, "Scientific change, emerging specialties, and research schools", History of science, xix (1981), 20-40; J. S. Fruton, Contrasts in scientific style: research groups in the chemical and biochemical sciences (Philadelphia, 1990).

24. I. Hacking. The taming of chance (Cambridge, 1990), p. 6. See A. C. Crombie, "Philosophical presuppositions and shifting interpretations of Galileo", in J. Hintikka, D. Gruender and E. Agazzi (eds), Theory change, ancient axiomatics, and Galileo's methodology (Dordrecht, 1981), pp. 271-86, esp. p. 284. Cf. I. Hacking, "Language, truth and reason", in M. Hollis and S. Lukes (eds), Rationality and relativism (Oxford, 1982), pp. 48-66.

25. L. Boon, De list der wetenschap - variatie en selectie: vooruitgang zonder rationaliteit (Baarn, 1983). However, X-ray analysis was also used in a deductive approach by, for instance, Linus Pauling, who used this methodology to elucidate the basic structure of proteins, i.e. the alpha-helix. 
different definitions of the objects of study. ${ }^{26}$ Anticipating the case studies a single example may illustrate the impact of different research styles.

In the 1940s a controversy arose between the physicist Max Delbrück and the biological chemist John H. Northrop. While Delbrück studied bacteriophage as a simple model for the multiplication of a gene, Northrop used bacteriophage as a model for the study of protein synthesis. These contrasting notions resulted not only in different experimental techniques but especially in different demarcations with respect to the phenomena which were relevant for their research. To Northrop, lysogeny was a crucial phenomenon, while Delbrück doubted the validity of such observations. We will see that in all case studies the controversies were not only pursued at a theoretical level, but were also strongly embedded in conflicts about how experiments had to be performed and what could be regarded as a valid object of study.

The concept of 'research style' can be operationalised in several ways. One method is to give a description in terms of the theoretical and experimental activities of the researchers, and this is the method which will be used in the present study. A sociological characterisation would imply distinguishing a research style by identifying social and institutional relations between researchers. This can be achieved by studying personal networks, training, institutions, professional and disciplinary organisations, journals, etcetera. ${ }^{27}$ It will be clear that if it is claimed that a research style can be characterized in theoretical and experimental terms, one must also be able to identify a social dimension which is specific for this style. The medical philosopher Ludwik Fleck stressed this point by arguing that a 'thought style' is carried by a 'thought collective'. ${ }^{28}$ However, in this study I will limit myself to the theoretical and experimental dimensions of the research styles to be identified.

26. For the importance of a certain style in dealing with anomalies and the use of models and metaphors see, for instance, D. Bloor, "Some determinants of cognitive style in science", in Cohen and Schnelle, op. cit. (ref. 22), pp. 387-97; Boon, op. cit. (ref. 25). An interesting case of an object (a virus-infected mosquito) being construed into different research objects (into a vector by Carlos Finlay and into a host by Walter Reed, respectively) is described in F. Delaporte. The history of yellow fever: an essay on the birth of tropical medicine (Cambridge, Mass., 1991).

27. Such an analysis has been made for the 'Phage Group'; see N. C. Mullins, "The development of a scientific specialty: the Phage Group and the origins of molecular biology", Minerva, $\mathrm{x}$ (1972), 51-82. However, the history of phage research cannot be restricted to the 'Phage Group', as is shown in Chapters 4, 5 and 6 of this study. For an overview of the sociological literature on the growth and decline of scientific disciplines and 'specialties' see H. Zuckerman, "The sociology of science", in N. J. Smelser (ed.), Handbook of sociology (Newbury Park, 1988), pp. 51 1-74.

28. See literature on Fleck in reference 22. 
The identification of specific approaches and research styles will be based upon the techniques, experiments, models, metaphors and theories employd by the researchers involved. It will be shown that the interpretation of the research on viruses and virus diseases occurred along the lines of the various disciplines involved, such as bacteriology, biochemistry, physical chemistry, genetics and epidemiology. These diverse disciplinary interpretations resulted in quite different answers to the question of the nature of a virus as well as that of the nature of a virus disease.

As was indicated above, one finding of the present study is that in the first half of the 20th century, an antithesis can be recognized between an exogenous and an endogenous interpretation of viruses and virus diseases. In the first approach, a virus was seen as an entity, whereas in the second a virus disease was interpreted as a disturbance of the physiology of the host cell. The exogenous interpretation encompassed physicochemical, bacteriological, genetic as well as ecological research styles. Since the antithesis between the endogenous and exogenous interpretations is a recurrent element in the various case studies, it seems legitimate to describe them as two generalized thought styles. ${ }^{29}$ The presence of this antithesis in virus research suggests a parallel with the role of themata and antithemata as identified by Gerald Holton in the history of physics. ${ }^{30}$

\subsection{RESEARCH STYLES, CONTROVERSIES AND CONTINUITY}

In the history of virus research, two concepts can be recognised, separated in time, which functioned as stabilizing points within virus research. In the beginning of the 20th century this was the concept of the 'filterable virus', while in the 1950s it was the 'modern concept of virus' which provided consensus. This leads to the question how the formation of consensus in these two cases was achieved and how the first concept transformed into the second, while at the same time maintaining conceptual continuity.

In the standard view of science, the growth of scientific knowledge is projected as a continuing and accumulating process, in which more and more is learned about 'nature'. Normally, the history of virus research is described in such a way as the progressive uncovering of kowledge about nature, i.e. viruses. Thus, conceptual

29. An example of such a generalized thought style is formulated in $\mathrm{H}$. van den Belt and $\mathrm{B}$. Gremmen, "Specificity in the era of Koch and Ehrlich: a generalized interpretation of Ludwik Fleck's 'serological' thought style", Studies in history and philosophy of science, xxi (1990), 463-79.

30. G. Holton, Thematic origins of scientific thought; Kepler to Einstein (Cambridge, Mass., 1973, revised edition, 1988). Cf. H. Kragh, An introduction to the historiography of science (Cambridge, 1987). 
continuity is thought to be caused by the existence of viruses as real objects belonging to this natural category. Such a realistic interpretation of 'viruses' was, for instance, advocated by André Lwoff in 1957 when he claimed that a virus has to be considered a virus because it is a virus. ${ }^{31}$ A similar position was defended by Anthony $P$. Waterson when he wrote in the preface of An introduction to the history of virology that the history of virology is "the story of the progressive unveiling of the nature of the virus particle." 32 In such realistic notions of viruses, the reason for the formation of consensus is presented as originating in 'nature'.

Bruno Latour and Steve Woolgar argued in Laboratory life that a scientific fact is constructed during a process of 'splitting-and-inversion', involving the scientific knowledge claim on the one hand and 'nature' on the other. Experiments, observations and theories are used to construe 'nature' in the establishment of a 'scientific fact', during which the knowledge claim is detached from its modalities. Latour and Woolgar argued that with the presentation of the results of scientific research, this construction process is inversed and a scientific 'fact' is presented as if it is a consequence of objective 'nature'. ${ }^{33}$ The acceptation of the model of 'splitting-andinversion' implies that we cannot present 'nature' as the argument to explain the formation of consensus: we know things about nature because this is the result of the formation of consensus. In his Science in action, Bruno Latour described the same problem in a "rule of method" which states that since the "settlement of a controversy is the cause of Nature's representation, not its consequence, we can never use this consequence, Nature, to explain how and why a controversy has been settled." 34 [Italics in the original.] André Lwoff's answer to the question why a virus is a virus and Waterson's recapitulation of the history of virus research as "unveiling of the nature of the virus particle" are therefore to be rejected. The consensus on the "modem concept of virus' was arrived at because this definiton gave an acceptable answer to pathologists, phytopathologists, bacteriologists, biochemists, physicochemists, geneticists and epidemiologists to questions about the nature of viruses and the process of virus multiplication.

31. Lwoff, op. cit. (ref. 7), p. 252

32. A. P. Waterson, "Aims, possibilities and objectives", in Waterson and Wilkinson, op. cit. (ref. 9), pp. ix-xiii, esp. p. xii.

33. B. Latour and S. Woolgar, Laboratory life: the construction of scientific facts, (Princeton, N. J., 1986); S. Woolgar, Science: the very idea (Chichester, 1988).

34. B. Latour, Science in action: how to follow scientists and engineers through society (Milton Keynes, 1987), p. 258. 
If we accept the model of 'splitting-and-inversion' for the construction of a scientific fact, it is understandable that once a scientific fact has been constructed and included in the repertoire of scientific facts ('ready-made science'), it is difficult to determine how this fact was constructed, i.e. stripped of its modalities. Therefore, Bruno Latour argued that if one wants to analyse the formation of a scientific fact, it is best to study 'science in the making'. ${ }^{35}$ In the following chapters I will follow this advice by concentrating on controversies which were abundantly present in virus research in the 20 th century. The formation of consensus which was obtained in the concept of 'filterable virus' and the 'modern concept of virus' will also be addressed.

\subsection{THE SELECTION OF CASE STUDIES}

The formation of consensus, for instance about the 'modern concept of virus', will be analysed by describing the processes by which the actors underpin their knowledge claims. In the selection of the developments in the history of virus research in the 20th century which are to be analysed, retrospective elements have been incorporated in two ways. Firstly, in that I discuss case studies of viruses infecting one of the three main groups of host organisms (animals, plants and bacteria) as they are now perceived. Secondly, because I discuss bacteriophage research by scientists who argued that bacteriophage was not to be characterized as a virus. Since, according to present consensus, bacteriophage can be characterized as a bacterial virus, these scientists may be included among the predecessors of virus research, even though the scientists themselves denied the interpretation of bacteriophage as a bacterial virus.

Since the construction processes of scientific facts are most visible during controversies, the case studies will concentrate on such controversies. Five essays present analyses of research on tobacco mosaic virus, influenza viruses and bacterial viruses (bacteriophages) in the 20th century.

Chapter 2 describes the study of mosaic disease in tobacco. Tobacco mosaic virus (TMV) was the first etiological agent which was found to be filterable and it has ever since played a prominent part in virus research. For more than half a century the nature

35. Latour, op. cit. (ref. 34). The study of scientific controversies is a useful lever for studying 'science in the making', an approach which has also been central to other programmes in science studies such as the 'Empirical programme of relativism'. See H. M. Collins (ed.), "Knowledge and controversy: studies of modern natural science", Social studies of science, xi (1981), 1-158. Cf. E. McMullin, "Scientific controversy and its termination"; E. Mendelsohn, "The political anatomy of controversy in the sciences", in H. T. Engelhardt, Jr. and A. L. Caplan (eds), Scientific controversies: case studies in the resolution and closure of disputes in science and technology (Cambridge, 1987), pp. 49-91 and pp. 93-124, respectively. 
of TMV was a subject of discussion, which in the 1930s and 1940s meant the opposition between a physicochemical and a biochemical approach. Within each of these interpretations, totally different answers were given to the question of the nature of tobacco mosaic virus.

Chapter 3 presents an analysis of the research on influenza and its presumed etiological agent, as an example of research on animal viruses. In the first two decades of the 20th century it was thought likely that the bacterium Haemophilus influenzae was the cause of influenza. However, this presupposition became less likely when this bacterium could not be unambiguously indicated as the cause of influenza during the influenza pandemic of 1918-1920. Then, in 1931, a filterable virus was isolated from swine, followed by the isolation of a filterable agent in patients with influenza in 1933. In this case study it is argued that the research on the etiological agent of influenza was characterized by a bacteriological paradigm until far into the 1940s. This conclusion is based on the finding that, although the agent was identified as a filterable virus, the influenza virus was conceived of as a microbe.

The third type of virus research concerns the bacteriophage and this is the type analysed most thoroughly in the present study. Chapters 4 and 5 describe two controversies on the bacteriophage phenomenon, one in the 1920s and another in the 1940s. In Chapter 6 it is analysed how consensus on the nature of bacteriophage was constructed in the 1950s. This consensus was to make an important contribution to the articulation of the 'modern concept of virus', which was fundamental to the establishment of virology as an independent scientific discipline.

Finally, Chapter 7 presents an overview of the research styles traced in the case studies and of the contributions made by the various styles to the "modern concept of virus'. Furthermore, it is described how the existence of controversies can be consistent with the conceptual continuity which appears to be present in the transition from the concept of 'filterable virus' to the 'modern concept of virus'. From this analysis it will be concluded that the process by which conceptual continuity was reached in virus research corresponds with the dynamics of concepts in the history of the research of the cell and that of genetics. 36

36. For the historiography of biomedical disciplines related to virology see, for instance, $\mathrm{W}$. Bechtel, "The evolution of our understanding of the cell: a study in the dynamics of scientific progress", Studies in history and philosophy of science, xv (1984), 309-56; R. Falk, "What is a gene?", idem, xvii (1986), 133-73: R. E. Kohler, "The history of biochemistry: a survey". Journal of the history of biology, viii (1975), 275-318; R. E. Kohler, From medical chemistry to biochemistry: the making of a biomedical discipline (Cambridge, 1982). 

CHAPTER 2

What is a Virus? The Case of Tobacco Mosaic Disease

CONTENTS

2.1 The discovery of a filterable agent $\mathbf{2 4}$

2.2 Early chemical and bacteriological studies $\mathbf{2 7}$

2.3 The isolation of tobacco mosaic virus $\mathbf{3 1}$

2.4 A physicochemical approach $\mathbf{3 4}$

2.5 A biochemical approach 39

2.6 TMV and the modern concept of virus $\mathbf{4 4}$

2.7 Diversity revisited $\mathbf{4 8}$

2.8 Conclusion: plurality of concepts $\mathbf{5 2}$

Adapted from

Studies in History and Philosophy of Science, vol. 22 (1991), pp. 557-588. 


\section{CHAPTER 2}

\section{What is a Virus? The Case of Tobacco Mosaic Disease}

At the end of the nineteenth century researchers, remembering the success of bacteriology, discovered that some of the agents causing infectious diseases could pass through ultrafilters. Such filters were thought to be impervious to corpuscular or 'organized' agents. Soon many agents of infectious diseases of plants, animals and man were found to be (ultra)filterable. Despite incertitudes about borderline cases, the first decade of the twentieth century saw the rise of a category of infectious agents typified as 'invisible microorganisms' or 'filterable viruses'. At the end of the nineteenth century, the term 'virus' was used for any agent of infectious disease, while by the 1930s it was only used for those that could be filtered, thus making the adjective 'filterable' obsolete. ${ }^{1}$

In creating the category of 'filterable virus' (or 'virus') researchers were implicitly confronted with the question: What is a Virus? In fact, this question was answered in two ways. On the one hand, it was defined operationally, namely as an agent which was filterable and invisible with light-microscopic techniques. ${ }^{2}$ On the other hand, the question arose as to the nature of these filterable agents. The answers to this query were divergent, and ranged from an ultramicrobe, a globulin and a colloid to a 'free gene'.

Mosaic disease of the tobacco plant was the first contagious disease whose etiological agent was passed through an ultrafilter. Ever since that moment, the agent, tobacco mosaic virus or TMV, has remained in the forefront of virus research. Hence a description of the history of TMV research provides an adequate survey of the history of the concept of virus in the twentieth century. ${ }^{3}$

1. The development of virology is described in, for instance, R. Doerr, 'Die Entwicklung der Virusforschung und ihre Problematik', in R. Doerr and C. Hallauer (eds), Handbuch der Virusforschung (Wien: Julius Springer, 1938), pp. 1-125; F. M. Burnet, 'An Historical Introduction to Animal Virology', in his Principles of Animal Virology (New York: Academic Press, 1955), pp. 1-32; S. S. Hughes, The Virus: A History of the Concept (London: Heinemann Educational Books, 1977); A. P. Waterson and L. Wilkinson, An Introduction to the History of Virology (Cambridge: Cambridge University Press, 1978)

2. See, for instance, T. M. Rivers, 'The Nature of Viruses', Physiological Reviews 12 (1932), 423-452, p. 423. See also Chapter 7 of the present study. 
As will be argued in this essay, most of the interpretations of the nature of tobacco mosaic virus up to the mid-1930s can be regarded as belonging to one of two approaches. The first interpreted the agent as a small microbe or ultramicrobe, the second regarded it as a chemical product, probably produced by the plant itself, or multiplying by some kind of autocatalytic mechanism. The crystallization of TMV in 1935, a hallmark in virus studies, combined elements of both approaches, viz. the autonomy of the virus and a chemical nature. But again different points of view developed, this time between a physicochemical approach of TMV and a biochemical approach, a division which lasted for more than two decades. It will be argued that these diverging approaches gave different answers to the question What is the virus of tobacco mosaic disease? The late 1950s showed the emergence of a consensus on the nature of viruses, defining them as nucleic acid surrounded by protein. But less than ten years later, new concepts were proposed which broke up the newly achieved consensus.

Thus, it will be argued that the major interpretations of TMV which were suggested in the twentieth century can be ordered into research styles. I will not give a sociological delineation of these research styles, but will articulate them by analyzing the publications of influential researchers within the scientific domain of plant virus studies. Nor does the scope of the present essay allow an elaboration of the question whether these different approaches gave rise to research schools. ${ }^{4}$ The aim of the

3. Historiographical material on the history of research on tobacco mosaic virus and plant viruses in general can be found in F. C. Bawden, Plant Viruses and Virus Diseases (Leiden: Chronica Botanica Company, 1939); M. T. Cook, Viruses and Virus Diseases of Plants (Minneapolis: Burgess, 1947); M.K. Corbett, 'Introduction', in M. K. Corbett and H. D. Sisler (eds), Plant Virology (Gainesville: University of Florida Press, 1964), pp. 1-16; L. Wilkinson, "The Development of the Virus Concept as Reflected in Corpora of Studies on Individual Pathogens: 3. Lessons of the Plant Viruses - Tobacco Mosaic Virus', Medical History 20 (1976), 111-134; G. C. Ainsworth, Introduction to the History of Plant Pathology (Cambridge: Cambridge University Press, 1981); H. Fraenkel-Conrat, 'Portraits of Viruses: Tobacco Mosaic Virus', Intervirology 15 (1981), 177-189; M. A. Lauffer, 'Contributions of Early Research on Tobacco Mosaic Virus', Trends in Biochemical Sciences 9 (1984), 369-371; L. E. Kay, 'W. M. Stanley's Crystallization of the Tobacco Mosaic Virus, 1930-1940', lsis 77 (1986), 450-472. The articles of Mayer (1886), Ivanovski (1892), Beijerinck (1898) and Baur (1904) on tobacco mosaic disease and variegation (vide infra) are included in English in J. Johnson (ed.), Phytopathological Classics Number 7 (Ithaca, N.Y.: Cayuga Press, 1942). Excerpts of the articles of Mayer (1886). Beijerinck (1898), Holmes (1929), Stanley (1935), Fraenkel-Conrat \& Williams (1955) and Gierer \& Schramm (1956) on tobacco mosaic disease and virus (vide infra) are reprinted in English with comments in $\mathrm{N}$. Hahon (ed.), Selected Papers on Virology (Englewood Cliffs, N.J.: Prentice-Hall, 1964). 
essay is to show that different approaches in TMV research existed over more than half a century.

In the history of virus research the controversies between different approaches were regularly commented on from the point of view of a 'perspective explanation'; two examples are cited here. In 1947 the plant pathologist Starr Chester wrote: "The biologist, who regards the viruses as living, studies them in living hosts where they behave as organisms; the chemist, who considers them chemicals, studies them in the test tube where he sees only their chemical and physical properties." ${ }^{5}$ Expressing the same, the plant virologist Heinz Fraenkel-Conrat wrote, in 1981: "Just as the five blind men may describe an elephant differently, so plant pathologists, virologists, tobacco-growers, and biochemists surely see TMV differently."6 It will be argued that this explanation of the existence of different approaches as views from different perspectives, is a mistaken metaphor. The different approaches resulted in different research objects as an answer to the question What is a virus?

\subsection{THE DISCOVERY OF A FILTERABLE AGENT}

In the last decades of the nineteenth century, tobacco plants of Dutch tobacco growers were plagued by a devastating disease. Adolf Mayer, an agricultural chemist of German origin and director of the Agricultural Experimental Station at Wageningen (Holland) took up the study of this disease in 1879. He published his results seven years later. ' To prevent confusion with other diseases, he suggested replacing local names like 'bunt', 'rust' and 'smut' by 'tobacco mosaic disease'. By sucking the emulsion of a ground diseased tobacco leaf into a capillary glass tube and injecting this into a large leaf vein of a healthy plant, Mayer was able to transmit the disease in nine out of ten cases. He concluded that the disease was infectious, but was unable to isolate a bacterial cause with the bacteriological techniques available. Since he observed that the agent in the emulsion was held back by a double layer of filtration paper, Mayer concluded that the agent was 'organized'; an 'unorganized ferment' could be excluded as the cause of the disease.

In the mid-1880s, Martinus Beijerinck was a colleague of Mayer's at Wageningen

4. For literature on research styles and research schools see Chapter 1 of the present study.

5. K. S. Chester, Nature and Prevention of Plant Diseases (Philadelphia: Blakiston, 19472), p. 313

6. H. Fraenkel-Conrat, op. cit, note 3, pp. 185-186.

7. A. Mayer, 'Die Mosaikkrankheit des Tabaks', Die landwirtschaftlichen Versuchs-Stationen 32 (1886), 451-467. 
and hence knew of the results of the latter's studies on tobacco mosaic disease. In 1887 Beijerinck looked for anaerobic bacteria as the cause of the disease, but without result. Ten years later, Beijerinck was given the opportunity to work in a new bacteriological laboratory at the Polytechnical School at Delft, where he resumed the study of tobacco mosaic disease. He found that the infectious agent could pass through a porcelain ultrafilter, and to extend his findings he performed a diffusion experiment in which the emulsion was placed on a layer of agar. He tested the question "whether the contagium was actually capable of diffusion and, accordingly, had to be considered as soluble in water, or if not capable of diffusion, therefore, as extremely minutely distributed, yet as corpuscular, that is, as contagium fixum." 8

From his observation that the agent moved a few millimeters into the agar, Beijerinck concluded that the virus should be considered as not corpuscular, thus being liquid or soluble. A second property that he attributed to the agent was that it reproduced itself: a plant could be inoculated with only a very small amount of the filtered emulsion, after which a small quantity of the filtered sap of the newly infected plant could cause the disease in another healthy plant. Such a serial transmission was thought to be indicative of the multiplication of an agent, which therefore had to be living. For the agent of tobacco mosaic disease, Beijerinck combined the properties of living and non-corpuscular, and suggested a new category of contagium vivum fluidum.

Stating that the diffusion into agar points to the fluid nature of the agent of mosaic disease may seem like jumping to conclusions. In the historical literature this unconventional step of Beijerinck is linked to his friendship with the first Nobel Prize winner for chemistry, Jacobus van 't Hoff. Furthermore, the possibility that filterable viruses could be non-particulate was ridiculed. ${ }^{9}$ It must be pointed out, however, that what was at stake in the early decades of the research of filterable viruses was not whether they were material particles or not. In fact, the debates centred on the relation with the Pasteurian view that infectious diseases were caused by living microbes that were thought of as organized, which was equated with corpuscular. Although

8. M. W. Beijerinck, 'Über ein Contagium Vivum Fluidum als Ursache der Fleckenkrankheit der Tabaksblätter', Verhandelingen der Koninklijke Akademie van Wetenschappen te Amsterdam 65 (1898), 3-21; translated in J. Johnson (ed.), op. cit., note 3, pp. 33-52, see p. 35. For biographical material on Beijerinck see G. van Iterson, Jr., L. E. den Dooren de Jong and A. J. Kluyver, Martinus Willem Beijerinck: His Life and Work (The Hague: Martinus Nijhoff, 1940).

9. L. Wilkinson, op. cit, note 3, p. 117: A. P. Waterson, op. cit, note 1, pp. 27-30, esp. p. 27, note 1 and p. 28 , note 3 . 
Beijerinck did not continue his research on TMV, he maintained all his life the view that life is not limited to 'structural' entities. In 1913 he stated that "the criteria of life ... are also compatible with the fluid state." And in 1922 he stated, in a Dutch article 'Pasteur and Ultramicrobiology', that the size of bacteriophage (at present conceived of as bacterial virus) was of the same order as a protein molecule and that the name contagium vivum fluidum expressed this similarity. ${ }^{10}$

Beijerinck's paper was published in 1898 in a Dutch journal, and in 1899 an abridged paper appeared in the Centralblatt für Bakteriologie, which soon provoked a comment from Dmitri Ivanovski. The latter argued that he had already shown the filterability of the agent of tobacco mosaic disease through a Chamberland filter several years earlier and that testing the diffusability of the agent in agar, although very clever, was only more of the same. Ivanovski criticized Beijerinck's interpretation of the nature of the agent. Because Ivanovski had been able to transmit the disease via bacterial colonies, he claimed that it could not be doubted that the contagium could be classified as belonging to the bacteria."

The dichotomy that structured the discussion on the nature of tobacco mosaic virus for many decades can be discerned in the position of Beijerinck. On the one hand, there was the interpretation that TMV was a living agent and therefore 'organized' and corpuscular. Had the great Louis Pasteur not written that "every virus is a

10. Van Iterson, Jr., op, cit., note 8, p. 120; M. W. Beijerinck, 'Pasteur en de Ultramicrobiologie', Chemisch Weekblad 19 (1922), 525-527, p. 527. The question why Beijerinck did not continue his work on tobacco mosaic virus is not answered in his biography (see Van Iterson, Jr., op. cit, note 8, pp. 118-121). To me, a reason seems to be that in the second phase of Beijerinck's scientific career "the plate culture was his proper field of operations." (ibid., p. 38) Hence it may be that the very impossibility of cultivating TMV in artificial media made further experimentation infeasable for him.

11. M. W. Beijerinck, 'Über ein Contagium Vivum Fluidum als Ursache der Fleckenkrankheit der Tabaksblätter', Centralblatt für Bakteriologie, Parasitenkunde und Infektionskrankheiten, Abt. II, 5 (1899), 27-33; D. Ivanovski, 'Über die Mosaikkrankheit der Tabakspflanze', ibid., Abt. II, 5 (1899), 250-254. Ivanovski referred to D. Iwanowski, 'Über die Mosaikkrankheit der Tabakspflanze', Bulletin de l'Académie Impériale des Sciences de St. Pétersbourg, n.s. 3 (35) (1894), 67-70. This paper was presented on 12 February, 1892 to the scientific academy of St. Petersburg but was only published in 1894.

Based on the differences in interpretation that Beijerinck and Ivanovski gave to the nature of tobacco mosaic virus, Thomas Rivers and Louis Kunkel differed on who was the real founder of virus research. Kunkel gave priority to Ivanovski while Rivers reserved this honour for Beijerinck. See S. Benison. Tom Rivers: Reflections on a Life in Medicine and Science (Cambridge, Mass.: MIT Press, 1967). pp. 115-116. 
microbe"? ${ }^{2}$ This interpretation belonged to the paradigm of bacteriology, a science which was established in the second half of the nineteenth century. The second interpretation was that the virus was an inert chemical product and thus belonged to the domain of chemistry.

Adherence to the latter chemical notion confronted researchers with the problem of how to explain the multiplication of the agent. Within the chemical paradigm it was generally assumed that the filterable agent was a product of the infected host cell and thus endogenous. But there were also defenders of the notion that the chemical product could reproduce itself, Beijerinck being one of them. The position of Beijerinck was atypical for both background sciences in that he combined the properties of life and 'unorganized'. More conventional explanations of the reproduction of a chemical substance referred for instance to the phenomenon of autocatalysis. Jules Bordet, who worked on bacteriophage from the early 1920s, argued that an autocatalytic process was, for instance, known in the formation of thrombin. ${ }^{13}$ Such processes offered an analogy for the reproduction of chemical substances. In the next section we will see that the abovementioned two notions, i.e. the bacteriological and the chemical, constituted the paradigmatical contexts of the research on tobacco mosaic virus in the first decades of the twentieth century.

\subsection{EARLY CHEMICAL AND BACTERIOLOGICAL STUDIES}

In 1899 Albert Woods published studies on the discoloration of chlorophyl, the substance which gives a plant its green color. Woods suggested that the browning of leaves in autumn could be ascribed to the action of oxidizing enzymes. In certain disorders, like tobacco mosaic disease, where degradation of chlorophyl was manifest, the enzymes oxidase and peroxidase could be the cause of the disease. Although Woods could not pass these two enzymes through an ultrafilter, they did migrate into agar. Therefore, he was convinced that the cause of tobacco mosaic disease was to be found in the plant itself and not in an exogenous agent. He observed that when rapidly growing tobacco plants were cut back, newly-grown leaves developed mosaic-like appearances: "The young shoots grew very rapidly and were invariably mottled and often distorted exactly as in the mosaic disease."14

12. L. Pasteur, 'Rabies', New Review 1 (1889), 505-512 and 619-630, p. 506.

13. See, for instance, J. Bordet, 'Croonian Lecture - The Theories of Bacteriophage', Proceedings of the Royal Society of London, Ser. B, 107 (1931), 398-417, pp. 405-406. See also Chapter 4 of the present sludy.

14. A. F. Woods, 'The Destruction of Chlorophyll by Oxidizing Enzymes', Centralblatt fuir 
The spontaneous generation of infectious microbial disease was a notion banished from bacteriology since the work of Louis Pasteur. To Woods, his experience with the artificial creation of a mosaic disease suggested the endogenous origin of tobacco mosaic disease. He suggested that the disease was a disturbance of the normal physiological activity of the cells, possibly caused by enhanced activity of the enzymes peroxidase and oxidase. ${ }^{15}$ Similar ideas were defended in the thesis 'Contagiöse Pflanzenkrankheiten ohne Mikroben' by Kurt Heintzel. This scientist argued that tobacco mosaic disease was caused by an oxidase which became more active or was produced in abnormally large quantities. ${ }^{16}$

The endogenous origin of tobacco mosaic disease was also defended by Friedrich Hunger, although he rejected the Woods-Heintzel hypothesis that sought the cause in oxidizing enzymes. According to Hunger, this hypothesis could not explain the serial transmissibility, and his observations on filtration also contradicted such an explanation. Hunger found the agent of mosaic disease to be filterable through 'Diffusionshulzen', whereas the oxidizing enzymes were not. Hunger interpreted tobacco mosaic disease as a metabolic disease caused by a toxin normally present in the cell but inactive. In a state of extreme metabolism the toxin would accumulate and result in a perturbation of metabolism. The option that mosaic disease was caused by a bacterium was rejected by Hunger, because no microorganism was isolated that could be put forward as the cause of the disease. Furthermore, he had observed that in field experiments the disease was not infectious so the etiological agent could not be a 'living substance'. He supposed that the disease could be transmitted artificially because the toxin was able in normal cells to exert a physiological contactual action with the result "dass sich dort sekundär dasselbe Toxin bildet, mit andern Worten das Mosaikkrankheitstoxin besitzt die Eigenschaft, physiologisch-autokatalytisch zu wirken."17

As it did for Hunger, the limited transmissibility of certain infectious diseases also Bakteriologie, Parasitenkunde und Infektionskrankheiten, Abt. II, 5 (1899), 745-754, p. 751.

15. A. F. Woods, 'Observations on the Mosaic Disease of Tobacco', United States Department of Agriculture Bureau of Plant Industry, Bulletin 18 (1902); cited in M. K. Corbett, op. cit., note 3 , p. 3.

16. K. G. E. Heintzel, Contagiöse Pflanzenkrankheiten ohne Mikroben - Unter besonderer Berücksichtiging der Mosaikkrankheit der Tabaksblätter (Inaug. Diss. Friedrich Alexander Universität, Erlangen, 1900); cited in F. W. T. Hunger, 'Untersuchungen und Betrachtungen über die Mosaikkrankheit der Tabakspflanze', Zeitschriff für Pflanzenkrankheiten 15 (1905), 257-311, see p. 269 and p. 310.

17. F. W. T. Hunger, op. cil., note 16, p. 296. 
prompted Erwin Baur to call in question the strict parasitic nature of these diseases. Baur studied infectious variegation or chlorosis of Abutilon and noticed that in Europe variegated and non-variegated plants grew side by side without any proof of the transmissibility of the disease. As the disease could be transferred by the artificial route, Baur concluded that there were infectious diseases which were not caused by a living organism. Therefore, for a thorough understanding of the etiology of such infectious diseases - including tobacco mosaic disease - the "old dogma of the unconditionally parasitic nature of all infectious diseases seems to me [Baur] to be only an obstruction." 18

A chemical interpretation of the problem of the nature of tobacco mosaic virus was also defended in the mid-1920s. Maurice Mulvania studied the inoculation of tobacco mosaic virus in animals, the effect of bacteria on the virus, the possibility of dialysing the virus and the effect of light and heat on the agent. ${ }^{19}$ These studies attempted to decide the question whether TMV was a living entity or belonged to the colloids. His observations contradicted the properties of a living agent, which was supposed to consist of complex protoplasm and a reasonable quantity of protein. Mulvania concluded that TMV was more like a colloid. But accepting the colloidal nature of TMV, Mulvania had to explain the multiplication of a lifeless substance. He suggested that two hypotheses could reasonably explain this. The first one assumed the autocatalytical production of TMV as a product of metabolic activity of the plant. Virus, produced by another plant, would cause the production of new virus material in the newly infected cell. Examples which he suggested could be used as analogies were the enzymatic transformation in the endosperm of germinating grain and the multiplication of bacteriophage. The second hypothesis formulated by Mulvania was that tobacco mosaic virus had a place in the evolutionary development from dead to living substances. It was suggested that tobacco mosaic virus could show a property of ']ife' (i.e. multiplication) without the other properties that marked 'life' (e.g. nourishment, response and adaptation) in later stages of evolutionary development. Mulvania did not opt unambiguously for one of the two alternatives, but he expressed his opinion on the nature of TMV. His results were in conformity to the colloidal nature of fowl plague virus as was suggested in the studies by Mrowka (1912) and P. Andriewsky (1914).

18. E. Baur, 'Zur Ätiologie der infektiösen Panachierung', Berichte der deutschen botanischen Gesellschaft 22 (1.904), 453-460; translated in J. Johnson (ed.), op. cit, note 3, pp. 55-62, see p. 62

19. M. Mulvania, 'Studies on the Nature of the Virus of Tobacco Mosaic', Phytopathology' 16 (1926), 853-871, p. 862 . 
Mulvania concluded that TMV could best be thought of as "a non-living thing, possibly a very simple colloid, possibly also of protein nature and having enzymatic characteristics." 20

In contrast to these interpretations of TMV as a chemical substance, probably of endogenous origin, other researchers interpreted tobacco mosaic disease within the paradigm of bacteriology which, after all, was the conventional context of infectious diseases. Cornelis Koning studied the stability of the virus of tobacco mosaic disease in the soil, its susceptibility to glycerin, alcohol, heat, etc. On the basis of these experiments, Koning concluded that TMV was a multiplying, living poison and that it had to be classified as a microorganism. ${ }^{21}$

That tobacco mosaic disease was indeed caused by an ultramicroscopic parasite was, after extensive investigations, also defended by Harry Allard. ${ }^{22} \mathrm{He}$ confirmed earlier claims of the filterability of the virus through Berkefeld filters and showed that the disease could be caused by very small quantities of the virus. The virus was thought to be 'foreign' ('extraneous') to the protoplasm of a healthy plant and, once introduced into a healthy plant, to multiply very rapidly. Furthermore, Allard observed that when TMV was purified, no correlation was found between the infectious agent and peroxidase or catalase activity. Albert Woods' hypothesis became, according to Allard, untenable. His own experiences indicated that "there is every reason to believe that it is an ultramicroscopic parasite of some kind." According to the English plant virus researcher Frederick Bawden, Allard's work was very influential and for a long time it was believed that TMV was an organism. ${ }^{23}$ But in addition to the possibilities of the virus being a microorganism or a chemical substance, a third option was defended, especially by Benjamin Duggar and Joanne Karrer (Armstrong). These

20. M. Mulvania, op. cit., note 19, p. 870; Mrowka, 'Das Virus der Hühnerpest ein Globulin', Centralblatt für Bakteriologie, Parasitenkunde und Infektionskrankheiten, Abt. I, Orig., 67 (1912), 249-268; P. Andriewsky, 'L'Ultrafiltration et les Microbes Invisible', ibid., Abt. I, Orig., 75 (1914), 90-93.

21. C. J. Koning, 'Die Flecken- oder Mosaikkrankheit des holländischen Tabaks', Zeitschrift für Pflanzenkrankheiten 9 (1899), 65-80.

22. H. A. Allard, 'Effect of Dilution upon the Infectivity of the Virus of the Mosaic Disease of Tobacco', Journal of Agricultural Research 3 (1915), 295-299; H. A. Allard, 'Some Properties of the Virus of the Mosaic Disease of Tobacco', ibid, 6 (1916), 649-674; H. A. Allard, 'Effects of Various Salts, Acids, Germicides, etc. upon the Infectivity of the Virus Causing the Mosaic Disease of Tobacco', ibid., 13 (1918), 619-637.

23. H. A. Allard (1916), op. cit, note 22, p. 672; F. C. Bawden, Plant Viruses and Virus Diseases (New York: Ronald Press, 19644), p. 5. 
scientists suggested that the causal agent of tobacco mosaic disease could be a product of the host cell, something like chromatin or a gene. ${ }^{24}$

\subsection{THE ISOLATION OF TOBACCO MOSAIC VIRUS}

Since the 1880 s standard techniques for the isolation and culturing of pure microbial disease causing agents had been available. Culturing bacteria on solid media was found to be especially successful in the isolation and characterization of pathogenic microbes. ${ }^{25}$ Culturing filterable viruses appeared to be much more difficult and by the 1920 s there was some consensus that the filterable viruses could not be cultured on inert media at all. By that time, the obligatory dependency of virus growth on living host cells was more or less accepted as typical for the filterable viruses.

As was shown in the previous section, it was suggested in many studies that TMV should be considered an endogenous product and possibly of a colloidal nature. If that was true, it had to be possible to apply the chemical techniques that had proved so useful in the study of proteins, antigens and antibodies. Because of the similar properties of fowl plague virus and colloids, Mrowka used the methods and techniques of the study of antigens and antitoxines in his study on the fowl plague virus. He concluded that in such a study the 'Basic Principle of Bacteriology' had to be abandoned and he resorted to the use of the chemical and physical methods that had been used so effectively in the study of bacterial antigens. However, Mrowka warned that the 'vital moment' of the virus should not be interfered with. ${ }^{26}$

Likewise, Harold McKinney concluded that the 'pure culture' techniques from bacteriology were useless for the virus of tobacco mosaic disease. Therefore, he continued his research using the chemical and physical methods of purification. McKinney purified TMV by precipitating heavy suspended particles with the use of a centrifuge, without diminishing the infectivity of the supernatant. Further purification and isolation steps used heat-coagulation and further centrifugation. ${ }^{27}$ That the

24. B. M. Duggar and J. L. Karter, 'The Sizes of the Infective Particles in the Mosaic Disease of Tobacco', Annals of the Missouri Botanical Garden 8 (1921), 343-356; B. M. Duggar and J. Karrer Armstrong, 'Indications Respecting the Infective Particles in the Mosaic Disease of Tobacco', ibid., 10 (1923), 191-212.

25. See, for instance, T. D. Brock, Robert Koch: A Life in Medicine and Bacteriology: (Madison: Science Tech Publishers, 1988).

26. Mrowka, op. cit., note 20 , p. 250 and p. 253, respectively.

27. H. H. McKinney, 'Quantitative and Purification Methods in Virus Studies'. Journal of Agricultural Research 35 (1927), 13-38; cf. H. H. McKinney. 'Factors Affecting Certain Properties of a Mosaic Virus', ibid., pp. 1-12. 
chemical techniques known from immunity studies could be used for TMV research was also made plausible by the studies on the antigenic properties of another mosaic virus. Mayme Dvorak produced antisera in rabbits against a mosaic virus isolated from potatoes. These antisera were not completely specific, but the homologous reaction with infected sap was much stronger than that with sap of a non-infected plant. Helen Beale (née Purdy) reported extensive studies on the antigenic properties of tobacco mosaic virus. Beale observed that antiserum contained an antibody that was strongly specific for the sap of virus infected plants, and that this specific antiserum could neutralize the infectivity of TMV. ${ }^{28}$ Such studies constituted a rationale for the study of TMV with the chemical armamentarium.

Important progress in the isolation of tobacco mosaic virus was made by Carl Vinson of the Boyce Thompson Institute for Plant Research at Yonkers (New York). In 1927 Vinson published a new technique for the preparation of infected cell sap. Freshly cut diseased tobacco leaves were frozen, which meant that the cells were broken up. The material was then thawed and subjected to high pressure and the application of centrifugation and precipitation techniques resulted in increasingly pure preparations. The isolation of pure tobacco mosaic virus was also attempted elswhere. ${ }^{29}$

The work on the isolation of mosaic virus was seriously handicapped by the laborious method of estimating the numbers of virus particles. This was usually achieved by inoculation of a sample into a plant, in which systemic infection was the indicator for the presence of the virus. ${ }^{30}$ Quantifying tobacco mosaic virus was made much easier by a technique developed by Francis Holmes of the Boyce Thompson

28. M. Dvorak, 'The Effect of Mosaic on the Globulin of Potato', Joumal of Infectious Disease 41 (1927), 215-221. H. A. Purdy, 'Immunologic Reactions with Tobacco Mosaic Virus', Proceedings of the Society for Experimental Biology and Medicine 25 (1928), 702-703; H. A. Purdy, 'Inmunologic Reactions with Tobacco Mosaic Virus', Journal of Experimental Medicine 49 (1929), 919-936; H. P[urdy] Beale, 'Specificity of the Precipitin Reaction in Tobacco Mosaic Disease', Contributions from Boyce Thompson Institute for Plant Research 3 (1931), 529-539.

29. C. G. Vinson, 'Precipitation of the Virus of Tobacco Mosaic', Science 66 (1927), 357 358; C. G. Vinson and A. W. Petre, 'Mosaic Disease of Tobacco: 1. Progress in Freeing the Virus of Accompanying Solids', Botanical Gazette 87 (1929), 14-38; C. G. Vinson and A. W. Petre, 'Mosaic Disease of Tobacco: II. Activity of the Virus Precipitated by Lead Acetate', Contributions from Boyce Thompson Institute for Plant Research 3 (1931), 131-145; E. Barton-Wright and A. M. McBain, 'Possible Chemical Nature of Tobacco Mosaic Virus', Nature 132 (1933), 1003-1004; J. Caldwell, 'Possible Chemical Nature of Tobacco Mosaic Virus', Nature 133 (1934), 177.

30. H. H. McKinney, op. cit., note 27, pp. 13-38. 
Institute. In 1928 Holmes published a method in which virus was inoculated into leaves of Nicotiana tabacum by means of needle pricks. When tobacco mosaic virus infected the leaf through such a needle prick, a local lesion developed. Within a few days a mosaic structure developed which was a sign of systemic infection. As local lesions were not always very clear, Holmes studied the effect of the new method of inoculation in other host plants. In Nicotiana glutinosa local lesions developed very rapidly, in some cases even within 30 hours after inoculation. Furthermore, even the needle pricks were not necessary in this host plant. The sample could be taken up in cheese cloth, which was used to rub the leaf once after which it was rinsed with water. If virus was present, local lesions developed within 4 to 5 days. These were found to be proportional to the concentration of the virus in the inoculum. Undiluted samples of a mosaic infected tobacco plant resulted in 300-600 lesions in the test plant. Holmes made it clear that with this quantitative method a substitute had been found for the impossibility of culturing the virus on artificial media: "A standardized method for using $N$. glutinosa as a test plant for measuring the concentration of mosaic virus gives as rapid and as accurate results as the determination of bacterial numbers by plating methods." 31

In 1935 Science published an article by Wendell Stanley, in which he claimed the crystallization of tobacco mosaic virus. Stanley was recruited in 1931 by Louis Kunkel, the head of the newly established Division of Plant Pathology of the Princeton branch of the Rockefeller Institute (New Jersey). Stanley made use of Vinson's freezing method and Holmes' local lesion technique. By studying the preservation of infectivity under widely diverging conditions (changes in $\mathrm{pH}$, salt concentrations), Stanley developed a procedure of purifying TMV. After several steps, Stanley obtained a colorless preparation, from which a 'globulin' could be crystallized by the addition of half saturated ammonium sulphate in $5 \%$ acetic acid. In this way he obtained needles with a length of $0.03 \mathrm{~mm}{ }^{32}$

The crystallization of TMV set the seal on the chemical approach to the isolation of tobacco mosaic virus. The result was shocking. A virus, with its property of multiplication, a fundamental property of 'life', was found to be crystallizable and thus

31. F. O. Holmes, 'Accuracy in Quantitative Work with Tobacco Mosaic Virus', Boranical Gazette 86 (1928), 66-81; F. O. Holmes, 'Local Lesions in Tobacco Mosaic', ibid., 87 (1929), 39-55, also published in Contributions from Boyce Thompson Institute 1 (1929), 504-520; reprinted in N. Hahon (ed.), op. cit., note 3, pp. 124-137, see p. 136.

32. W. M. Stanley, 'Isolation of a Crystalline Protein Possessing the Properties of TobaccoMosaic Virus', Science 81 (1935), 644-645. 
belonged to the domain of chemistry. In the popular press Stanley's finding was widely acknowledged in newspaper articles with headings like 'Crystals isolated at Princeton believed unseen disease virus', 'Life in the making', 'Invisible virus held link between life and death', and 'Virus apparently made visible at last'. 33 But most importantly, there now was absolute certainty that the virus of tobacco mosaic disease itself could be advantageously studied with physicochemical methods. As Francis Holmes had explained, the "behavior of the virus under experimental conditions, such as filtration, purification by chemical processes, and contact with disinfectants has always been judged by its reinoculation into living plants." 34 Now that TMV was isolated and with the rise in the 1930s of advanced techniques like the ultracentrifuge, the electrophoresis apparatus, X-ray diffraction analysis and, in the 1940s, the development of the electron microscope, one could study the intrinsic properties of the virus. The British plant virus researcher Kenneth Smith commented on this in 1948: "The isolation of tobacco mosaic virus by Stanley in 1935 ... was the key which opened the door to the study of the virus itself, quite apart from the disease it may cause." 35 However, we will see in a later section that the relevance of the physicochemical approach of studying TMV was not shared by everyone.

\subsection{A PHYSICOCHEMICAL APPROACH}

The crystallization of TMV by Stanley was a glorious success for the physicochemical approach to the study of the processes of life at the Princeton branch of the Rockefeller Institute. This institute had become a centre of excellence for the isolation and study of enzymes. The key figure in this reputation was John Northrop, who became famous for the isolation and crystallization of enzymes like pepsin and trypsin. Besides these epoch-making achievements, Northrop's studies on the criteria of purity were based on high theoretical standards. His solubility studies in particular were the ultimate touchstone of purity at the time. ${ }^{36}$

Northrop and his co-workers also isolated so-called precursors of enzymes, e.g. chymotrypsinogen, trypsinogen and pepsinogen, which could be transformed into the active enzymes chymotrypsin, trypsin and pepsin, respectively. This was interpreted by Northrop as a process by which enzymes, or proteins in general, could be formed.

33. See L. E. Kay, op. cit., note 3, pp. 465-466.

34. F. O. Holmes. op cit., note 3I, in N. Hahon (ed.), p. 135.

35. K. M. Smith, 'Plant Virus Research at Cambridge', Nature 161 (1948), 776-777, p. 777.

36. See, for instance, J. H. Northrop, 'Isolation and Properties of Pepsin and Trypsin', Harvey Lectures 30 (1936), 229-270. 
In the case of trypsin and pepsin, the formation of the active enzyme from an inactive precursor was catalyzed by the end product, thus illustrating the existence of an autocatalytic process. ${ }^{37}$

Stanley published his research on tobacco mosaic virus in this context of physicochemical studies of enzymes, the biological catalysts thought to belong to the fundamentals of life. The crystallization of TMV clearly showed that viruses were "at the edge of life': some of their properties, such as multiplication, mutation and adaptation, placed these 'midgets of life' within living nature, while at the same time they apparently belonged to the chemical domain of substances which could be purified and crystallized. Stanley's crystallization of TMV had an enormous impact on the debate about the question What is Life? It is all the more remarkable that in the first two or three years after 1935 such an influence was not noticeable on the theory of the gene. As has been stated by Robert Olby and Lily Kay, the virus-gene analogy was not elaborated by the Northrop School in the mid 1935s. ${ }^{38}$

This virus-gene analogy is generally placed in the context of the "enzyme theory of life' which was elaborated by, among others, Leonard Troland and Hermann Muller. In historical literature it is often claimed that Muller in particular was very influential because of his proclamation of the virus-gene analogy. Elof Carlson stated that in 1922 Muller recognized the "utility of viruses for genetic research ..." ${ }^{39}$ However, it is important to note that Muller's contribution is wrongly interpreted in all cases. The quotation that is usually cited as evidence for the virus-gene analogy runs like this:

[I]f these d'Hérelle bodies were really genes, fundamentally like our chromosome genes, they would give us an utterly new angle from which to attack the gene problem. They are filterable, to some extent isolable, can be handled in test-tubes ... perhaps we may be able to grind genes in a

37. See, for instance, J. H. Northrop, 'Chemical Nature and Mode of Formation of Pepsin, Trypsin and Bacteriophage', Science 86 (1937), 479-483; J. H. Northrop, 'The Formation of Enzymes', Physiological Reviews 17 (1937), 144-152. See also L. E. Kay, op. cit, note 3, and T. van Helvoort. 'The Controversy between John H. Northrop and Max Delbrück on the Formation of Bacteriophage: Bacterial Synthesis or Autonomous Multiplication?', Annals of Science 49 (1992), 545-575; included as Chapter 5 of the present study.

38. R. Olby, The Path to the Double Helix (London: Macmillan, 1974), p. 151; L. Kay, op. cit, note 3, p. 459, esp. note 28.

39. E. A. Carlson, 'An Unacknowledged Founding of Molecular Biology: H. J. Muller's Contributions to Gene Theory, 1910-1936', Journal of the History of Biology 4 (1971), 149-170, p. 162; R. Olby, op. cit., note 38, p. 151; A. W. Ravin, 'The Gene as Catalyst; the Gene as Organism', Studies in the History of Biology 1 (1977), 1-45, p. 28. 
mortar and cook them in a beaker after all. 40

Muller was speaking of d'Hérelle bodies and d'Hérelle substances which were called bacteriophages by their discoverer, Félix d'Hérelle. It is important to note that Muller did not use the term (bacterial) virus for these bodies and did not identify himself with the interpretation d'Hérelle gave to the nature of bacteriophage, viz. as a virus. A further reason why the analogy of viruses with genes was not elaborated at Princeton was that Northrop regarded bacteriophage as a product of the bacterium and not as a bacterial virus. ${ }^{41}$ But let us return to TMV.

By the work of Stanley tobacco mosaic virus was transferred to a new scientific domain which was reflected in the change in the audience to which Stanley addressed himself. His extensive report on the isolation and crystallization of TMV was published (like five earlier studies) in Phytopathology. ${ }^{42}$ But subsequent studies — an improved method of isolation of TMV, the extension of his research to aucuba mosaic virus, further physicochemical studies on TMV and the influence of time on the infectious process - appeared in the Journal of Biological Chemistry. The study of tobacco mosaic virus was liberated from the effect of the virus in a host, i.e. the context of pathology.

The isolation of TMV as crystals of globulinous material meant to Stanley that TMV could be characterized as a molecule. The multiplication of the virus could be a process of autocatalysis: "Tobacco-mosaic virus is regarded as an autocatalytic protein which, for the present, may be assumed to require the presence of living cells for multiplication." 43 The next and logical step was that the new physicochemical research methods, such as the ultracentrifuge and electrophoresis apparatus, were applied to the newly isolated preparations. ${ }^{44}$ The result of these studies was that for tobacco mosaic virus and possibly for plant viruses in general, the interpretation that

40. H. J. Muller, 'Variation Due to Change in the Individual Gene', American Naturalist 56 (1922), 32-50, p. 48.

41. T. van Helvoort, op. cit., note 37.

42. W. M. Stanley, 'Chemical Studies on the Virus of Tobacco Mosaic: VI. The Isolation from Diseased Turkish Tobacco Plants of a Crystalline Protein Possessing the Properties of Tobaccomosaic Virus', Phytopathology 26 (1936), 305-320

43. W. M. Stanley, op. cit, note 32, p. 645.

44. B. Elzen, Scientists and Rotors: The Development of Biochemical Ultracentrifuges (Enschede: Thesis University of Twente, 1988); L. E. Kay. 'Laboratory Technology and Biological Knowledge: The Tiselius Electrophoresis Apparatus, 1930-1945', History and Philosophy of the Life Sciences $10(1988), 51-72$. 
these viruses could be like small microbes or ultramicrobes was abandoned. One assumption within the ultramicrobial notion of TMV was that they multiplied like bacteria, that is in a process of growing and then dividing into to two identical daughter cells. This process was also called binary fission, and as a consequence of such a process, the sizes of the individual organisms in a culture of multiplying organisms had to show a continuous distribution. This was falsified by the results of the physicochemical studies. A first investigation that pointed to the discrete distribution of the sizes of tobacco mosaic virus was the work performed by The Svedberg and Inga-Britta Eriksson-Quensel with the ultracentrifuge on tobacco mosaic virus material isolated by Stanley.

Because the Rockefeller Foundation had helped to finance the expensive equipment in Svedberg's laboratory in Uppsala (Sweden), this laboratory was in close contact with the Rockefeller Institute. The question which Eriksson-Quensel and Svedberg tried to answer was whether TMV had to be seen as a "living being with the faculty of propagation or a high-molecular compound with the property of multiplication by autocatalysis". Although these authors observed some inhomogeneity in the preparation, they did not exclude the possibility that the virus in its 'native state' could be homogeneous. The hypothesis which they rejected on the basis of their results was that the virus could be a kind of bacterium. The chemical homogeneity observed could not be explained if it were assumed, as would be the case if the virus were of bacterial nature, that various TMV particles were in different stages of growth. They thought their results could best be explained by the assumption that the virus is "a chemically well-defined protein, probably homogeneous with regard to molecular weight (17 millions) in the plant."45 In June 1937, at the fourteenth Colloid Symposium at Minneapolis (Minnesota), Wendell Stanley claimed that the macromolecules had been extended by a new group, namely the virus proteins. This presented opportunities for a "new experimental approach to the general problem of the nature of viruses." 46

What were the techniques that were used within the physicochemical approach? The testing of homogeneity in relation to velocity of sedimentation in the ultracentrifuge and electrochemical behaviour under electrophoresis have already been

45. I.-B. Eriksson-Quensel and T. Svedberg, 'Sedimentation and Electrophoresis of the Tobacco Mosaic Virus Protein', Journal of the American Chemical Society 58 (1936), 1863-1867, p. 1863 and p. 1867, respectively; cf. A. S. McFarlane, 'The Plant Virus Proteins', in T. Svedberg, K. O. Pedersen, et al., The Ultracentrifuge (Oxford: Clarendon Press, 1940), pp. 391-395. The particle weight of TMV was later estimated as about 40 million.

46. W. M. Stanley, 'Virus Proteins - A New Group of Macromolecules', Joumal of Physical Chemistry 42 (1938), 55-70, p. 69. 
mentioned. In addition, fractional crystallization, ultracentrifugation under different chemical conditions, solubility studies, correlation studies between absorption and destruction spectra and studies of partial inactivation were also part of the (physico)chemical test arsenal. Serological experiments comprised the precipitin test, the complement fixation test and in vivo and in vitro anaphylactic tests. Biological tests were used to estimate virus activity of the fractions obtained. ${ }^{47}$

The research into the nature of viruses centred on two problems: what was a virus? and what was the mechanism of the process of virus multiplication? As was mentioned above, Stanley suggested in his 1935 Science article that multiplication of TMV might involve a process of autocatalysis. In 1937 Stanley withdrew this suggestion, for two reasons. The first one was that it had not proved possible to isolate a precursor from which active virus could be made. His second reason was that multiplication of TMV was only observed in living cells, whereas Northrop et al. had shown that the activation of trypsinogen to trypsin could be performed in vitro. As virus multiplication in a process of binary fission could be excluded on the basis of the homogeneity of the virus material, he looked for a different analogy for the process of virus multiplication. Stanley argued that the process could be analogous to the growth of cells, which was not to be confused with their multiplication by binary fission. Stanley suggested that a fruitful analogy could be seen in the action of surface-forces, as suggested by Irving Langmuir. Growth or crystallization could take place because of the presence of a pattern. In this hypothesis the cell was viewed as a depository of substances, in which the virus protein constituted a stable form and functioned as a pattern for the further organization of component parts, analogous to crystal growth. Not only virus proteins could be produced in such a process, the growth of protoplasm could also be conceived of in this manner. ${ }^{48}$

The research by Stanley, the physicochemical approach in the study of tobacco mosaic virus, can be seen as bridging the bacteriological and chemical approaches of the previous decades. Some elements of both approaches were taken up, other discarded. The physicochemical approach combined the notion of TMV as an autonomous entity, borrowed from the bacteriological approach, and the chemical nature of TMV, derived from the chemical approach. The ultramicrobial nature and the endogenous origin were elements that were thought of as not applicable.

Stanley's work meant that neither of the two abovementioned approaches won a

47. W. M. Stanley, 'The Reproduction of Virus Proteins', American Naturalist 72 (1938), 110-123, p. 113 .

48. W. M. Stanley, op. cir., note 47, p. 122. 
total victory: a new position was created. According to Stanley, tobacco mosaic virus could be characterized as an autonomous chemical macromolecule. The association of autonomy and a chemical nature was established as the result of the crystallization of TMV and the physicochemical studies that followed this accomplishment. However, the endogenous origin of TMV would soon find support from another side. This was not because TMV could be characterized as a simple chemical product and multiplication therefore had to be explained by referring to host cell metabolism, as was done in the chemical approaches until 1935. The physicochemical approach of Stanley et al. was to be criticized by scientists who were concentrating on the pathology of the virus disease. According to this criticism, expressed by two English scientists, virus multiplication originated in the disruption of the physiological metabolism of the host cell. Although this criticism was inspired by pathological and physiological observations, it was worked out according to a biochemical approach in the 1940 s and I will use the latter designation to characterize their approach to the problem of (plant) virus multiplication.

\subsection{A BIOCHEMICAL APPROACH}

The publication by Stanley in Science was to be criticized by phytopathologist Frederick Bawden and biochemist Bill Pirie. These English researchers had been studying plant viruses for some time when Stanley's article appeared. After Bawden moved from the Potato Experimental Station at Cambridge to Rothamsted, they had the opportunity to study tobacco mosaic virus. Within a few weeks they prepared 'liquid crystalline' TMV substances. The chemical analyses of the preparations they isolated differed from the data reported by Stanley. The latter had reported a nitrogen content of $20 \%$ and the absence of phosphorus and carbohydrates (sugars). Bawden and Pirie, however, came up with $0.5 \%$ phosphorus and $2.5 \%$ carbohydrate, which could be isolated as ribonucleic acid after denaturation of the material. They therefore designated their material as nucleoproteins. ${ }^{49}$ Later on, Pirie repeatedly claimed that Stanley had gradually assimilated these controversial data, thus avoiding the need of revoking his early claim that he really had isolated TMV in 1935. By 1938 Stanley acknowledged that TMV contained nucleic acid and thus had to be designated as a

49. F. C. Bawden, N. W. Pirie, J. D. Bernal and I. Fankuchen, 'Liquid Crystalline Substances from Virus Infected Plants', Nature 138 (1936), 1051-1052; F. C. Bawden and N. W. Pirie, 'The Isolation and Some Properties of Liquid Crystalline Substances from Solanaceous Plants Infected with Three Strains of Tobacco Mosaic Virus', Proceedings of the Royal Society of London, Ser. B, 122 (1937), 274-320. 
nucleoprotein, and not as a globulin as he had done in 1935.50

But in addition to their disagreement over the chemical characterization of TMV, Stanley on the one hand and Bawden and Pirie on the other also differed on the question of what tobacco mosaic virus was. As was shown in the previous section, Stanley argued that TMV was a homogeneous macromolecule which he based on his physicochemical studies. In 1938 Stanley expressed this as follows: "[A]ll of the data available at present indicate that the virus proteins fulfill the accepted chemical definition of a molecule as the smallest weight which cannot be subdivided without a complete change in the properties." Contrary to this, Bawden et al. questioned, from their first article onwards, whether the material they had isolated was the virus as it was present in the infected plant. They stated in 1936: "[W] feel that it is still not proved, nor is there any evidence that the particles we have observed exist as such in infected sap." 51

Bawden and Pirie incorporated into their 1936 article X-ray diffraction studies which had been performed by Pirie's friend J. D. Bernal. It may be thought that this particular technique fitted in better with the physicochemical approach of Stanley and might contradict the biochemical approach of the other camp. However, because of the paracrystalline nature of the TMV preparations, only the width of the particles was given, not their length. Pirie calculated that even in the most dilute inoculum that could cause infection many thousands of particles were present. Therefore the X-ray studies left the possible heterogeneous nature of Bawden and Pirie's virus preparations open. 52

In an extensive report on their TMV studies, Bawden and Pirie talked about infectious nucleoproteins. In a discussion on the question whether it was justified to call the isolated nucleoproteins the virus, they stated that, although there were strong indications for such an identity, there were also important arguments against this point of view. They argued that in the isolation of tobacco virus material precisely that property of viruses was lost that distinguished a virus from a bacterium: "During the processes of purification ... the virus undergoes a change that is not readily reversed,

50. N. W. Pirie, 'Retrospect on the Biochemistry of Plant Viruses', Biochemical Society Symposia 30 (1970), 43-56, p. 48; N. W. Pirie, 'Purification and Crystallization of Proteins', Annals of the New York Academy of Sciences 325 (1979), 21-34, p. 24; N. W. Pirie, 'Recurrent Luck in Research', in G. Semenza (ed.), Selected Topics in the History of Biochemistry: Personal Recollections: II (Amsterdam: Elsevier, 1986), pp. 491-520, see pp. 502-504.

51. W. M. Stanley, op. cit., note 46, p. 57; F. C. Bawden (1936), op. cit., note 49, p. 1052.

52. See N. W. Pirie (1986), op. cit, note 50, pp. 501-502. 
and loses completely the property that first distinguished tobacco mosaic virus as a new type of disease agent, namely, that it should pass fine filters." Furthermore, they had indications that TMV was present in the plant cell in the form of insoluble complexes. Therefore, they argued, it was very well possible that in making extracts of infected leaves - i.e. separating virus, leaf tissue and cell debris - some part of the virus was lost. ${ }^{53}$

These objections of Bawden and Pirie against the idea that the isolated 'crystalline' preparation was pure tobacco mosaic virus, were interpreted by the physicochemists as casting doubt on the claim that TMV is a particle of definite size. The physicochemists felt this point of criticism to be refuted by later studies on the dimensions of TMV. ${ }^{44}$ However, until well into the 1950s, Pirie would defend that tobacco mosaic virus was pleomorphous. ${ }^{55}$ The argument that is crucial to the point to be made in the present essay is that Bawden and Pirie used another definition of the nature of virus disease and of virus than was current within the physicochemical approach. In the latter context, a virus disease was interpreted as the result of virus multiplication or the formation of an autocatalytic virus particle, while Bawden and Pirie viewed a virus infection as a physiological disturbance of the metabolism of the host.

For those who presupposed the autonomy of the virus, the host was only a medium for the multiplication of the virus, which supplemented certain growth factors and the like, which the virus lacked. The symptoms of an infected host plant would be the result of a metabolic exhaustion provoked by the continuing conversion of host components into virus material. In his textbook Plant Viruses and Virus Diseases, published in 1939, Frederick Bawden criticized this view of virus multiplication. The severity of the symptoms, he argued, are seldom a guiding principle for the amount of virus present in an infected cell. It therefore appeared very unlikely to him that the symptoms of a virus infection are the result of the multiplication of the virus. ${ }^{56}$

53. F. C. Bawden (1937), op. cit., note 49, p. 311.

54. M. A. Lauffer, op. cit, note 3; S. S. Cohen, 'Frederick Charles Bawden', in F. L. Holmes (ed.), Dictionary of Scientific Biography; Suppl. II (New York: Scribner, 1990), pp. 58-61; S. S. Cohen, 'Wendell Meredith Stanley', in ibid., pp. 841-848.

55. N. W. Pirie, 'Material in Virus Preparations Not Necessary for the Manifestation of Characteristic Virus Properties', in G. E. W. Wolstenholme and E. C. P. Millar (eds), Ciba Foundation Symposium on the Nature of Viruses (London: Churchill, 1957), pp. 56-64, see p. 57.

56. Bawden expressed his approval of the notion of Jules Bordet, who defended that the multiplication of bacteriophage was the result of a change in the behaviour of cells which meant that, instead of normal metabolic products, phage was produced. Cf. F. C. Bawden, op. cit, note 3, pp. 262-264. 
For many years Stanley et al. on the one hand and Bawden and Pirie on the other would answer the question on the nature of virus and virus disease in a fundamentally different way. Two publications, both published in 1946, are typical in revealing the differences in approach of the two research groups. In that year Wendell Stanley, together with John Northrop and James Sumner, received the Nobel prize for chemistry for his isolation and purification of tobacco mosaic virus. In his speech at the Nobel ceremony, Stanley concluded that electron microscopic pictures of TMV, taken at three different places in the world, had shown that most TMV particles had a length of $280 \pm 8.6 \mathrm{~nm}$, a value which was in good agreement with the results obtained with other physirochemical methods. ${ }^{57}$

In the approach of Bawden and Pirie, plant viruses were considered as nucleoproteins, which meant they were not different from normal components produced by the host cell. They argued that, for this very reason, physicochemical methods were of no use in distinguishing between virus and host material. Only by using biological methods could one distinguish between infectious and non-infectious substances. Pirie stated that viruses could only be recognized by "their ability to bring about defined physiological changes in the host and not by their own intrinsic properties." Using physicochemical methods, Bawden and Pirie had observed that the process of isolation caused aggregation of particles. As they had observed that the mean length of particles in a virus preparation was determined by the "past history and present environment of the preparation", it did not seem reasonable to them that a particular physicochemical method would result in the virus particle. ${ }^{58}$

The physiological or biochemical approach of Pirie and Bawden was based on the presupposition that a virus infection could best be seen as a disturbance of host metabolism. This basic assumption had some important consequences, of which the impossibility of characterizing a specific particle as the virus was only the first. A second, related, consequence was that a plant virus infection led to the formation of

57. W. M. Stanley, "The Isolation and Properties of Crystalline Tobacco Mosaic Virus", in Nobel Lectures Chemistry 1942-1962 (Amsterdam: Elsevier, 1964), pp. 137-159, see p. 149.

58. N. W. Pirie, 'The Viruses', Annual Review of Biochemistry 15 (1946), 573-592, p. 574 and p. 584, respectively. Two articles which were finished after Bawden's death also point to the complexity of plant virus infections. See F. Bawden and N. W. Pirie, 'Factors Affecting the Amount of Tobacco Mosaic Virus Nucleic Acid in Phenol-Treated Extracts from Tobacco Leaves', Proceedings of the Royal Society of London, Ser, B, 182 (1972), 297-318; and idem, 'The Inhibition, Inactivation and Precipitation of Tobacco Mosaic Virus Nucleic Acid by Components of Leaf Extracts', ibid., pp. 319-329. 
many other products. These belong to the process of virus infection, but need not be infectious by themselves. In his article A Biochemical Approach to Viruses, Pirie argued that a real understanding of virus infection would require studying "all of the anomalous nucleoprotein". He emphasized that the structural specificity that was observed in the action of drugs and hormones may not hold true for viruses. 59

What can be said about intellectual influences on Pirie who, until 1940, worked at the Biochemical Laboratory, established by Frederick Hopkins, at Cambridge? In an autobiographical essay, Pirie stated that he was indebted to two teachers, Hopkins and G. F. C. Searle; after his graduation, J. B. S. Haldane was important. As far as Pirie's work on plant viruses is concerned, more particularly his biochemical approach, direct links between these teachers and Pirie's work cannot be traced. However, in a biographical essay on Hopkins, Pirie wrote:

The distinction between the approaches to phenomena of chemists and biochemists, i.e. between the study of the structure of a substance and of its function or metabolism, was made in many of Hopkins' articles. ... During the period when his [Hopkins'] Department was most productive (about 1925 to 1939) this attitude [having acute biological instincts] influenced almost all our work. ... He subtly directed our interests towards processes rather than substances. The word subtly should be stressed. He did not direct research but influenced it by his obvious interest in some aspects rather than others. ${ }^{60}$ [Italics in the original.]

It was an inherent factor in the biochemical approach of the virus problem that Bawden and Pirie paid much attention to the metabolism or physiology of the host. But here the influence of Bawden, the phytopathologist, also showed itself. Bawden stated that if one wanted to quantify the susceptibility of a plant to a virus, the characteristics of the plant were very important. The quantification of the virus was, for instance, dependent on the leaf surface and the volume of the sap, and therefore dependent on environmental factors. The defence mechanism of the host plant was also dependent on its physiological condition. The conclusion drawn by Bawden from

59. N. W. Pirie, 'A Biochemical Approach to Viruses', Nature 166 (1950), 495-496. Contrary to what Pirie thought possible, structural specificity was found in viruses: the virus is duplicated as a replica of the sequence of nucleotides in the virus genome.

60. Furthermore, Pirie was influenced by the work of his wife, 'Tony' Pirie, who worked on Rous sarcoma virus and then on bacteriophage. Those circumstances meant that Bill Pirie had many conversations with William Gye who worked on 'viruses and cancer' (see also Chapter 7 of the present study). See N. W. Pirie (1986), op. cit., note 50, pp. 493-494 and p. 501; N. W. Pirie, 'Sir Frederick Gowland Hopkins (1861-1947)', in G. Semenza (ed.), Selected Topics in the History of Biochemistry - Personal Recollections: I (Amsterdam: Elsevier, 1983), pp. 103-128 
these observations was that the virulence of a virus is not an intrinsic property of that virus, but "only a reflexion of a host-parasite interaction". Ten years later Bawden expressed himself more forcefully when he stated that the genetical constitution of a plant virus and that of the plant must permit an infection, but "nurture comes only a little behind nature in determining what happens when the two are brought together."61

\subsection{TMV AND THE MODERN CONCEPT OF VIRUS}

As was shown above, Bawden and Pirie's research on plant viruses in the 1940s had been very much influenced by their emphasis on the physiology of the host. In their view virus multiplication was interlinked with host cell metabolism. In the early $1950 \mathrm{~s}$ they reformulated this characterization and stated that virus multiplication is a special case of the synthesis of (nucleo)protein by the host. ${ }^{62}$ Whether a virus infection in bacteria, plants or animals was being considered, these could best be viewed as "metabolic disturbances of the host, which produce, among other things, more

61. F. C. Bawden, 'Some Effects of Host-Plant Physiology on Resistance to Viruses', Proceedings of the Royal Society of London, Ser. B, 135 (1948), 187-195, p. 188; F. C. Bawden, 'The Establishment and Development of Infection', in C. S. Holton et al. (eds), Plant Pathology: Problems and Progress 1908-1958 (Madison: University of Wisconsin Press, 1959), pp. 503-510, see p. 508. The question whether susceptibility to an infection is innate or is dependent on the environment is of course related to the wider nature/nurture controversy in society and, for instance, to the Lysenko affair in the U.S.S.R. Because of the friendship of Bill Pirie with marxists like J. D. Bernal and J. B. S. Haldane, one is tempted to ask whether the position of Bawden and Pirie in the late 1930s on the nature of tobacco mosaic disease was influenced by Lysenkoist biology. I cannot answer this question. On the political activities of Bernal, Haldane and Pirie see G. Werskey, The Visible College (London: Allen Lane, 1978). In this book, Bawden is not indexed.

Pirie argued that the susceptibility of plants to environmental conditions was disadvantageous if standard conditions were required. But if one wanted to study the influences of factors that regulate the reaction between host and infectious agent, this characteristic of environmental susceptibility was extremely useful. Such factors included the influence of the seasons; variations in light, temperature and food; the influence of chemical substances; the influence of an infection on the host metabolism; etc. Cf. N. W. Pirie, 'Frederick Charles Bawden 1908-1972', Biographical Memoirs of Fellows of the Royal Society 119 (1973), 19-63, p. 46.

62. F. C. Bawden and N. W. Pirie, 'Physiology of Virus Diseases', Annual Review of Plant Diseases 3 (1952), 171-188; F. C. Bawden and N. W. Pirie, 'Virus Multiplication Considered as a Form of Protein Synthesis', in P. Fildes and W. E. van Heijningen (eds), The Nature of Virus Multiplication - Second Symposium of the Society for General Microbiology (Cambridge: Cambridge University Press. 1953), pp. 21-45. 
material that can induce similar metabolic disturbances in other hosts." The emphasis that Bawden and Pirie, since their early work, had laid on the multiplicity of products as a result of virus infection fitted in nicely with this new concept. As a virus infection was a rearrangement of protein synthesis, a sharp demarcation between infectious and non-infectious virus material was unjustified. ${ }^{63}$

According to Bawden and Pirie the effect of a virus infection on a host was not so much the exhaustion of protein and nucleic acid precursors, but the extent to which the normal enzymatic processes in the cell were disturbed. The hypothesis which they forcefully rejected was that virus disease is the result of the multiplication of the virus particle. They rejected both notions which considered virus multiplication as the result of reproduction of autonomous entities: "[W] suggest that virus multiplication is comparable neither with the growth of a bacterium in a culture medium nor with the direct conversion of a precursor into an enzyme. Rather, it is a metabolic disturbance, which in any detail, primarily involves nucleoprotein metabolism." 64

Tobacco mosaic virus played a key role in the formulation of what Francis Crick called the 'Sequence Hypothesis'. This hypothesis states that the genetic information of an organism is encoded in the nucleic acid, with the sequence of bases of the nucleotides coding for the sequence of amino acids in a protein. ${ }^{65}$ The suggestion that nucleic acid carried the genetic information - thus excluding any role for protein in this matter - was a hypothesis that gained more and more adherents in the 1950 s. Clues which pointed in this direction were to be found in the studies on the Transforming Principle, on bacteriophage and on plant viruses. 66

63. F. C. Bawden (1952), op. cit, note 62, pp. 171-172.

64. Ibid., p. 185.

65. F. H. C. Crick, 'On Protein Synthesis', Society of Experimental Biology Symposia 12 (1958), 138-163. The second hypothesis postulated by Crick in this article is the famous 'Central Dogma'. As was emphasized by Crick [Nature 227 (1970), 561-563] the Central Dogma states that "once 'information' has passed into protein it cannot get out again." [Italics in the original.] In general, the term 'Central Dogma of Molecular Biology' is used for the flow of information from DNA to RNA to protein. The catchphrase 'Central Dogma' is not only used in this sense in Jim Watson's Molecular Biology of the Gene (New York: W. A. Benjamin, 1965, 1970²) but also in recent literature. See for instance H. Fraenkel-Conrat and P. C. Kimball, Virology (EnglewoodCliffs, N.J.: Prentice-Hall, 1982), p. 381

66. Former plant virologist Arthur Knight presented the following summary of essential contributions to the notion that nucleic acid is the carrier of genetic information: (a) bacterial transformation is caused by DNA (1944); (b) analysis of spontaneous mutants of TMV seemed to suggest a role for RNA (1947); (c) particles of turnip yellow mosaic virus without nucleic acid were 
With the acceptance of the genetic role of nucleic acid, the physicochemical research style defined a virus as a piece of nucleic acid, carrier of genetic information, surrounded by inert protein that functioned as a protective coat. ${ }^{67}$ The formulation of this structural model for viruses was very much stimulated by some observations on TMV. In the mid-1950s, a method was developed to dissociate TMV into subunits in an acid or weakly alkaline environment, whereby the addition of phenol or the detergent SDS prevented degradation of the ribonucleic acid. In the absence of RNA the subunits could aggregate, but the complex appeared to be non-infectious. It was only when RNA was present that reconstitution of active TMV was obtained. 68 Furthermore, undegraded RNA appeared to be infectious and to induce the formation of complete, protein-containing, virus particles. This experiment was interpreted as direct evidence for the role of RNA as the carrier of the genetic information of tobacco mosaic virus. ${ }^{69}$ In another experiment, nucleic acid and protein of different TMV strains were reconstituted together which, after infection, resulted in a TMV of which the protein was found to be characteristic for the virus from which the RNA was derived 70

The hypothesis that the genetic information was only carried in the nucleic acid and that this coded for the protein could also explain a finding in a study by Stanley et al. from the mid-1940s. Stanley and his co-workers regarded TMV, as a chemical molecule, and the problem of virus multiplication became in their hands the problem of how the molecular pattern of the virus was reproduced. To solve this question, they treated TMV preparations with chemicals which produced 'mutants'. After an infection found to be non-infectious (1949); (d) the infection of bacteria by certain coliphages appeared to be the result of the injection of viral DNA into the bacterial cells (1952); (e) the genetic role of RNA from tobacco mosaic virus could be shown directly (1956). See C. A. Knight, Molecular Virology (New York: McGraw-Hill, 1974), pp. 61-64. Cf. R. Olby, op. cit., note 38.

67. F. H. C. Crick and J. D. Watson, 'Structure of Small Viruses', Nature 177 (1956), 473475.

68. H. Fraenkel-Conrat, op. cit., note 3; H. Fraenkel-Conrat and R. C. Williams, 'Reconstitution of Active Tobacco Mosaic Virus from its Inactive Protein and Nucleic Acid Components', Proceedings of the National Academy of Science 41 (1955), 690-698.

69. A. Gierer and G. Schramm, 'Infectivity of Ribonucleic Acid from Tobacco Mosaic Virus', Nature 177 (1956), 702-703. Cf. H. Fraenkel-Conrat, "The Role of Nucleic Acid in the Reconstitution of Active Tobacco Mosaic Virus', Journal of the American Chemical Sociery 78 (1956), 882-883.

70. H. Fraenkel-Conrat and B. Singer, 'Virus Reconstitution: II. Combination of Protein and Nucleic Acid from Different Strains', Biochimica Biophysica Acta 24 (1957), 540-548. 
with such modified TMV molecules 'native' tobacco mosaic virus was always obtained. In 1948 Stanley concluded from this that either "the chemical derivatives were converted into ordinary virus following their introduction into the cells of the plant, or, more probably, that the infecting molecules may not necessarily function as exact patterns for reproduction." 11 With the hypothesis that genetic information was carried solely in nucleic acid and not in protein, Stanley's results could be explained by the assumption that the chemical modifications had only changed the latter and not the former. The reproduction of the virus on the basis of undamaged nucleic acid could explain why the progeny consisted of native virus. However, it is to be noted that the acceptance of the genetical role of nucleic acid, and the exclusion of such a role for protein, grew very slowly and was only completed in the late $1950 \mathrm{~s} \mathrm{~s}^{72}$

The consensus on the nature of viruses that was established in the middle of the 1950s was articulated in the definition of virus proposed by André Lwoff in 1957. According to Lwoff's definition, viruses are strictly intracellular and potentially pathogenic entities with an infectious phase. They meet the following criteria: (1) viruses have only one kind of nucleic acid; (2) they multiply in the form of their genetic material (nucleic acid); (3) they do not grow nor show binary fission; (4) they do not have a 'Lipmann system', the system of enzymes which convert the potential energy of foodstuffs into the high energy bonds which are needed for biological synthesis. ${ }^{73}$ This definition will here be designated as the modem concept of 'virus'.

In accordance with this modern definition of a virus, tobacco mosaic virus could be characterized as follows:

... TMV is a giant nucleoprotein molecule with a molecular weight of $40 \times 10^{6}$. It is composed of a single RNA sub-molecule with a molecular weight of about $2 \times 10^{6}$, the infectious unit, and over 2000 identical coat protein molecules, each with a molecular weight of $17493 . \ldots$ TMV is a molecule whose RNA component carries all the genetic information for replication and whose protein coat protects the RNA from a hostile environment. ${ }^{74}$

71. W. M. Stanley, 'Achievement and Promise in Virus Research', American Scientist 36 (1948), 59-68, p. 67.

72. Cf. C. A. Knight and D. Fraser, 'The Mutation of Viruses', Scientific American 193 (July) (1955), 74-78; C. A. Knight, 'Some Recent Developments in the Chemistry of Virus Mutants', in G. E. W. Wolstenholme and E. C. P. Millar (eds), Ciba Foundation Symposium on the Nature of Viruses (London: Churchill, 1957), pp. 69-78.

73. A. Lwoff, 'The Concept of Virus - The Third Marjory Stephenson Mernorial Lecture', Journal of General Microbiology 17 (1957), 239-253, p. 246. For a recent restatement of this definition see R. Hull, F. Brown and C. Payne, Virology: Directory \& Dictionary of Animal. Bacterial and Plant Viruses (London: Macmillan, 1989), p. 240. 
Lwoff's proposition formed a bridge between the exogenous and endogenous approaches that had influenced TMV research for many decades. Since the mid-1930s the physicochemical approach had viewed TMV as an autonomous macromolecule. In the new definition, a virus was indeed regarded as more complex than a single macromolecule, but this term could be used to designate the character of the nucleic acid which was the most important part of the virus. The regularity that was shown by physicochemical methods was explained by the regularity of the arrangement of the identical protein molecules that surrounded the nucleic acid. The dependence of virus multiplication on the physiology or metabolism of the host cell was in the modern concept of 'virus' explained by the dependence of virus multiplication on energyproviding host enzymes.

\subsection{DIVERSITY REVISITED}

Within the physicochemical approach, a virus disease was seen as the result of the multiplication of the virus, considered as an autonomous entity. This presupposition can be traced back to the germ theory of disease and the bacteriology of the second half of the nineteenth century. In Stanley's research group it was not doubted that TMV had to be characterized as a chemical molecule, but in the beginning the experimental evidence for this assumption was only meagre. This is clear from the following quotation from Max Lauffer, who in the early 1940s worked at the Princeton branch of the Rockefeller Institute:

That the virus rod is a molecule of definite dimensions and molecular weight was an article of faith motivating many in Stanley's laboratory. ... The shorter fragments, however, were worrisome. Were they merely broken rods, or were they the true virus molecules? This question was not answered for several years. ... Finally, Williams and Steere (1951), then at the University of Michigan, demonstrated beyond reasonable doubt that the short particles resulted from mechanical breakage of the fundamental unit. 75

For others, the electron microscopic photographs of tobacco mosaic virus constituted the evidence that TMV was a particle with a length of about $300 \mathrm{~nm}$. Heinz

74. M. A. Lauffer, op. cit., note 3, p. 371. Lauffer's use of the term 'molecular weight' here is incorrect; viruses (with the exception of viroids) have a particle weight. See $\mathrm{H}$. Fraenkel-Conrat, op. cit., note 3, p. 180.

75. M. A. Lauffer, op. cit., note 3, p. 370; the reference is to R. C. Williams and R. L. Steere. 'Electron Microscopic Observations on the Unit of Length of the Particles of Tobacco Mosaic Virus', Joumal of the American Chemical Society 73 (1951), 2057-2061. 
Fraenkel-Conrat remembered the

excitement Stanley created among us young scientists when he showed the first electron micrographs of TMV at a protein symposium at Stanford University in 1941 (...). The actual dimensions [of TMV] were derived from various physicochemical parameters in the late 1930s. However, seeing is believing, and we saw them first 40 years ago, $300 \mathrm{~nm}$ long cigarette-shaped rods. ${ }^{76}$

Within the physicochemical research style, the smaller particles in TMV preparations were thought of by most workers as breakage products, resulting from the process of isolation. Bawden and Pirie, however, maintained their position that virus disease could not be viewed as the result of multiplication of a specific virus entity. In 1966 Frederick Bawden clearly formulated the position which had been defended by him and Pirie for more than three decades: "For many years now the old idea has been untenable of virus multiplication being the direct replication of the infecting particles, giving a single end-product resembling the initial inoculum (...)."77 According to these scientists, virus multiplication resulted in a diversity of metabolic end products, differing in size, form and activity. So it was in line with Bawden and Piries' research that two 'models' for viruses were to be suggested that departed from the conventional concept of a virus being a singular infectious entity. These divergent ideas can be designated as the concepts of satellite viruses and divided genome viruses.

In 1938 Pirie had studied preparations of nucleoproteins from plants with tobacco necrosis. From 1941 to 1957 Bawden and Pirie published several articles on this disease. One of their results was that they could isolate a crystalline preparation that was not infectious and at the same time an infectious preparation that could not be crystallized. They suggested that the crystalline material could be a breakdown product of the amorphous infectious material, but could also be merely a specific disease product. ${ }^{78}$ Heterogeneity of the fractions was to Bawden and Pirie an essential element of their conception of virus disease. The complexity of the fractions they isolated confirmed their opinion that virus production was best explained as a distur-

76. H. Fraenkel-Conrat, op. cit, note 3, p. 179.

77. F. C. Bawden, 'Some Reflexions on Thirty Years of Research on Plant Viruses', Annals of Applied Biology 58 (1966), 1-11, p. 9.

78. F. C. Bawden and N. W. Pirie. 'Further Studies on the Purification and Properties of a Virus Causing Tobacco Necrosis', British Joumal of Experimental Pathology 26 (1945), 277-285; cf. B. Kassanis, 'Satellitism and Related Phenomena in Plant and Animal Viruses', Advances in Virus Research 13 (1968), 147-180; N. W. Pirie, op. cit, note 61, pp. 43-44. 
bance of host nucleoprotein metabolism.

In 1959 Basil Kassanis took over Bawden and Pirie's study of the tobacco necrosis virus. The methodological rules which Kassanis forced himself to obey were: (a) the isolation of viruses with the use of the 'single lesion' technique; (b) the utmost care in preventing contagion; (c) the distinction of the specific types of lesions which are caused by the different isolates; (d) the correlation of the infectivity of a preparation and the type of lesion, using the electron microscope. ${ }^{79}$ In 1960 Kassanis and Nixon published their experimental findings, which they interpreted with the concept of 'satellite virus'. The complexity of the isolated preparations from a plant with tobacco necrosis could be explained by assuming that the production of tobacco necrosis virus (TNV) was often accompanied by the production of another virus, i.e. the TNVsatellite virus (TNV-SV). This satellite virus depended for its multiplication on the presence of tobacco necrosis virus. When TNV multiplied in the presence of satellite virus, this usually resulted in a reduction in the quantity of TNV produced.$^{80}$

The concept of a satellite virus, however, was strictly speaking, not an anomaly to the assumption that viruses could be seen as singular entities, although a satellite virus is not an independent entity. In fact, TNV and its satellite virus were regarded as two viruses. The concept of 'divided genome viruses', on the other hand, did present such an anomaly to the unitary assumption. The prototype of the divided genome viruses is tobacco rattle virus (TRV), the study of which was pioneered by Richard Lister. According to Lister, the diversity in virus preparations was commonly seen as "representing faults in virus synthesis, stages in the synthesis of 'whole' particles, or degradation in the plant or as a result of purification." 81 For potato ring necrosis virus (PRNV), Colin Cadman had found that the presence of infectivity did not correlate with the severity of symptoms (cf. the work of Bawden and Pirie). Furthermore, in some cases no infectious virus could be isolated from plants which were clearly diseased. Such poorly transmissible viruses were called 'non-multiplying' viruses (NM-types), while virus from infectious sap was called the M-type. Around 1960, Lister and Cadman succeeded in isolating infectious material from NM-type preparations with the help of phenol, assuming that the chemical protected the RNA against destruction by nucleases. Furthermore, it had been known since 1955 that isolates of

79. B. Kassanis, 'Portraits of Viruses: Tobacco Necrosis Virus and its Satellite Virus', Intervirology 15 (1981), 57-70, pp. 63-66.

80. B. Kassanis and H. L. Nixon, 'Activation of One Plant Virus by Another', Nature 187 (1960), 713-714.

81. R. M. Lister, 'Tobacco Rattle Virus', Intervirology 26 (1986), 61-73, pp. 61-62. 
tobacco rattle virus contained two components, i.e. a short and a long particle (later on PRNV proved to be identical to tobacco rattle virus). In 1965 Lister was able to confirm his hypothesis that the short particles from TRV isolates determined whether infection by the long particles resulted in infection of the NM- or the M-type. The stable variant of the M-type was only obtained when long particles were accompanied by short particles. ${ }^{82}$

The findings for tobacco rattle virus would later on be generalized to the concept of 'divided genome viruses'. In such viruses the genetic information or genome is segmented, that is to say, divided over different particles. This division of the genome over two or more particles, which could be separated by physical means, implied that the conventional idea of viruses had to be abandoned. Plant virologist Ab van Kammen recognized the impact of the concept of a divided genome virus on the traditional concept of virus:

\begin{abstract}
Discovery of plant viruses with a divided genome has changed the concept of the nature of viruses. The classical concept implied that the mature virus, the ultimate phase of viral development, was a single particle, the virion, containing the genome of the virus. This is of course still true for many plant viruses, but no longer for all. ${ }^{83}$
\end{abstract}

Hence, the new concepts more or less contradict the notion that a virus infection could be thought of as the multiplication of a singular virus entity, as was then thought within the physicochemical approach. That a virus infection is more complex than the multiplication or replication of a single entity was in this approach easily countered by pointing out that TNV and TRV were not standard viruses. However, in the case of tobacco mosaic virus too it was revealed that the development of an infection was more complex than just multiplication. The emphasis on the diversity of the materials produced in virus disease, advocated for many years by Bawden and Pirie, was revived in the mid-1960s.

In $1965 \mathrm{H}$. Hulett and Hubert Loring performed experiments from which it was

82. R. M. Lister, 'Possible Relationships of Virus-Specific Products of Tobacco Rattle Virus', Virology 28 (1966), 350-353, p. 352; R. M. Lister, op. cit., note 81. In 1965, after reading an article by Bawden on the nature of viruses, Lister wrote to Bawden about his results which corroborated Bawden's ideas; see Lister, op. cit., note 81, pp. 69-70. Cf. F. C. Bawden, 'Speculations in the Origins and Nature of Viruses', in M. K. Corbett and H. D. Sisler (eds), Plant Virology (Gainesville: University of Florida Press, 1964), pp. 365-385, see p. 371.

83. A. van Kammen, 'Plant Viruses with a Divided Genome', Annual Review of Phytopathology 10 (1972), 125-150, p. 125. 
concluded that the infectivity of TMV was enhanced when smaller particles than those presumed exclusively to be infectious, were present. The mechanism they suggested for the observed increase in infectivity was that the smaller particles could provide coding information necessary for infectivity: "[T]he RNA's from the shorter viral units could serve as templates for some of these, supplementing the information carried by the standard particles and thus increasing their infectivity." $84 \mathrm{R}$. Francki also published research on the relation between infectivity and particle length. He too concluded that particles shorter than $300 \mathrm{~nm}$ could enhance the infectivity of particles of $300 \mathrm{~nm}$ or longer. His results indicated that "virus preparations are more infectious than would be expected if all short particles were incapable of infection." 85 In a general discussion on the role of non-infectious particles in virus infections (so-called 'defective interfering' or DI particles) Alice Huang and David Baltimore concluded that such particles could play an important role in the course of an infectious process:

... DI particles may be important determinants of the course of acute, self-limiting viral infections and of persistent, slowly progressing viral diseases. In addition, many host reactions may alter the production of DI particles and thus influence the outcome of viral infections. ${ }^{86}$

If we remember the presuppositions in the work of Bawden and Pirie it is remarkable how precisely these scientists had characterized the nature of virus infection. The emphasis on the complexity and diversity of this process in Bawden and Pirie's biochemical approach is clear in the following quotation of Pirie in 1970, a restatement of the approach they followed for many decades: "[T] the virus is the most relevant in any study of the details of virus multiplication and it is unwise to assume that anything removable from a virus preparation, without loss of infectivity, is an impurity." 87

\subsection{CONCLUSION: PLURALITY OF CONCEPTS}

At the beginning of the twentieth century filterable viruses, now named viruses, were studied within the context of late nineteenth century bacteriology. In this bacterio-

84. H. R. Hulett and H. S. Loring, 'Effect of Particle Length Distribution on Infectivity of Tobacco Mosaic Virus', Virology 25 (1965), 418-430, p. 429.

85. R. I. B. Francki, 'Some Factors Affecting Particle Length Distribution in Tobacco Mosaic Virus Preparations', Virology 30 (1966), 388-396, p. 395.

86. A. S. Huang and D. Baltimore, 'Defective Viral Particles and Viral Disease Processes', Nature 226 (1970), 325-327, p. 327.

87. N. W. Pirie (1970), op. cit., note 50, p. 53 
logical paradigm infectious diseases were thought of as caused by living organisms, microbes, which were thought to be singular and autonomous entities.

The fact that some infectious agents could be passed through ultrafilters constituted an anomaly in this common knowledge, for which several explanations were offered. The first answer suggested an ad hoc modification of the bacteriological paradigm and assumed the existence of ultramicrobes, i.e. small, living microbes. ${ }^{88}$ An alternative explanation, one that was especially influential in the case of tobacco mosaic disease, was suggested from a chemical context: the virus was presumed to be a protein or colloid. Within this suggestion the multiplication of the virus was thought to be the result of the metabolism of the host cell and thus TMV was regarded as an endogenous product. A third possibility that was suggested was a 'hybrid' between the other two: a chemical agent, but one which possessed one property of living nature, that of reproduction. Beijerinck put forward such a suggestion and created a new category for such an agent: a contagium vivum fluidum.

The bacteriological and chemical interpretations of tobacco mosaic virus would for more than three decades be the archetypes for explanations of the nature of TMV. The crystallization of TMV in the mid-1930s was the glorious start of a successful physicochemical approach or research style in plant virus research. A new 'hybrid' was to be formed between the bacteriological and chemical interpretations: TMV was supposed to be an autonomous chemical macromolecule. Within this interpretation it was difficult to explain the multiplication of TMV, although several hypotheses, based on processes of 'growth' that occurred in the chemical domain (autocatalysis and crystal growth), were offered.

The assumption that tobacco mosaic virus could be seen as an autonomous chemical macromolecule stimulated physicochemical studies of the processes of life and, in exchange, the research style justified the chemical interpretation of the nature of TMV. ${ }^{89}$ Nevertheless, the physicochemical approach came under attack from. scientists who studied virus diseases in plants from the point of view of plant pathology and the physiology of the host. Bill Pirie formulated the basic principle that guided his and Bawden's research as follows:

88. The enduring influence of a bacteriological paradigm in a particular case of virus research is argued in T. van Helvoort, 'A Bacteriological Paradigm in Influenza Research in the First Half of the Twentieth Century', History and Philosophy of the Life Sciences 15 (1993), in press; included as Chapter 3 of the present study.

89. Stanley and his co-workers also applied the physicochemical approach to the study of animal viruses, viz. influenza virus; see T. van Helvoort, op. cit, note 88. 
Bawden worked on the assumption that viruses could more properly be thought of as being made by the host than as multiplying in the host, not because he thought that we had demonstrated that they were particularly simple, but because of his extensive knowledge of the processes of infection and the differences between virus infection and infection by bacteria and funguses. 90 [Italics mine.]

We have seen that enquiries into the nature of tobacco mosaic virus were inherently linked with questions like What is a virus disease? and How does tobacco mosaic virus multiply? The contrasts between the physicochemical and the biochemical research styles stand out clearly when each answers the question on the nature of a plant virus. Stanley strongly defended the macromolecular nature of tobacco mosaic virus, while Pirie argued that it was complex and probably pleomorphous. I do not think that in the late 1950 s Pirie's position on this point was followed by many scientists. It seems probable that the majority of virus researchers supported the modern concept of virus expressed by André Lwoff in 1957. This definition was based on the division between the functions of nucleic acid and protein; the dependence of viruses on the metabolism of the host was interpreted as the dependence of the virus on the energy-providing system of the host cell. The modern concept of virus brought together the exogenous and endogenous approaches which had inspired TMV research for many decades. In the 1960 s work was published which again emphasized the complex nature of a TMV infection; or in other words, the new results denied the view that TMV infection is only produced by identical infectious TMV particles.

In my opinion the above has shown that for more than half a century several approaches existed in the research of tobacco mosaic disease. As was stated in the beginning of this article, the sociological dimensions of the establishment of such research styles could not be elaborated here. It will be clear that factors like leadership, access to graduate students and publications, the institutional setting, etc. were important. The case of Stanley especially seems to prove that the impact of leadership is very marked.91 What has been shown is that hypotheses and explanations fitted into research styles which were 'constructed' out of specific experimental set-ups, methodologies, scientific apparatus, analogies, etc.

There is, however, one important aspect of the conclusion of the present study that

90. N. W. Pirie, op, cit, note 61, p. 46.

91. On the influence of Stanley in the establishment of a 'school' on molecular virology (later on changed to molecular biology) see H. L. Fraenkel-Conrat, 'The Impact of Wendell M. Stanley on the Biochemical Sciences', Welch Foundation Conferences on Chemical Research 20 (1977), 254- 
needs further comment. Different research styles are normally regarded as the result of different positions with respect to the object studied. This then results in different descriptions or different pictures of the object under study. As is argued in this essay, the research styles distinguished here resulted in different definitions of the object of study. According to Bawden and Pirie a virus infection could be studied in two ways. The first was to record the response of a host to the virus. Characteristic reactions of the plant were its appearance and behaviour, its macroscopic and microscopic symptoms, or just the opposite: the form of resistance of the plant against a second infection. The second approach to the study of plant virus diseases was the demonstration of material that carried the infectivity, and the serological and physicochemical properties associated with the viruses studied. In 1952, Bawden and Pirie stated that

\footnotetext{
the two methods give essentially different types of information. The first tells how many plants, and approximately what proportion of each plant, have been affected; the second tells how much anomalous material can be extracted by the methods used. There is no general relationship between the two. ${ }^{92}$ [Italics mine.]
}

But if there is such a large gap between the research styles that they each have their own methodology, results and object of study, how could it be agreed that they both studied tobacco mosaic disease? How was communication between these research styles achieved? The answer to this question seems to me to be that the definition of TMV within each particular research style could exist alongside other definitions that were dominant in other research styles. Although these different conceptions could give rise to fierce discussions, they were understood by the adherents of the opposing research style, although of course the relevance of those conceptions was disputed.

The existence, side by side, of diverse definitions is recognized in the case of the gene. In the words of Philip Kitcher: "What we learn from molecular biology is the possibility of many different concepts of the gene, generated by different decisions about the phenotypic level. These concepts may be useful for different areas of research." 93 (Italics in the original.) By analogy with Kitcher's observation it can be stated that decisions on the level of the diseased plant resulted in different conceptions of the virus. In the case of the gene, Muriel Lederman argued that such different conceptions can even be used by one and the same scientist, and even in the same experiment, without leading to problems in consistency: "Biologists often employ

92. F. C. Bawden (1952), op. cit., note 62, p. 173.

93. P. Kitcher, 'Genes', British Journal for the Philosophy of Science 33 (1982), 337-359, pp. 355-356. 
different concepts of the gene at the same time and address different concepts of the gene simultaneously in the same experiment. Biologists have internalised a great many concepts of 'gene' and can restrict the gene concepts they discuss or employ in a particular context."94 (Italics in the original.) Such an internalisation of different concepts of the virus is, for instance, illustrated by the quotation given above in which Bawden and Pirie accepted Stanley's methodology as it was. 95

The co-existence, or plurality, of different conceptions of tobacco mosaic virus is also exemplified by the very reason why during the twentieth century scientists agreed upon the existence of something like tobacco mosaic disease. The definition of a disease of tobacco plants on the basis of a particular clinical picture, which could be transmitted by an ultrafiltrate, was another conception of TMV that existed side by side with the conceptions of the research styles discussed. The definition of tobacco mosaic virus as an infectious ultrafiltrate was, and still is, the very basis of our speaking of tobacco mosaic disease. The 'growing' knowledge of the nature of tobacco mosaic virus - ultramicrobe, macromolecule, disturbance of host metabolism, the role of DIparticles - was added to the definition of TMV that was proposed at the end of the nineteenth century. New knowledge did not replace at least one of the older definitions.

94. M. Lederman, "Genes" Amplified', British Journal for the Philosophy of Science 38 (1987), 56I-566, p. 561 .

95. The chasm between a physicochemical and a biochemical approach possibly also played a role in the discussion between Robert Gallo et al. and Peter Duesberg on the question whether the Human Immunodeficiency Virus is the cause of AIDS. See H. Rubin, 'Is HIV the Causative Factor in AIDS?: Nature $\mathbf{3 3 4}$ (1988), 201 
CHAPTER 3

\section{A Bacteriological Paradigm in Influenza Research in the First Half of the Twentieth Century}

CONTENTS

3.1 Introduction: filterable viruses $\mathbf{5 8}$

3.2 Pfeiffer's bacillus $\mathbf{6 0}$

3.3 The influenza pandemic of 191862

3.4 Filterable influenza virus $\mathbf{6 5}$

3.5 Manipulating the influenza virus 67

3.6 The bacteriological paradigm 69

3.7 Emancipation from the bacteriological paradigm $\mathbf{7 4}$

Adapted from

History and Philosophy of the Life Sciences, vol. 15 (1993), in press. 


\section{CHAPTER 3}

\section{A Bacteriological Paradigm in Influenza Research in the First Half of the Twentieth Century}

\subsection{INTRODUCTION: FIL TERABLE VIRUSES}

The germ theory of infectious disease entertains the notion that a living agent is the specific causal factor in a whole range of infectious diseases. The agent is an environmental factor, normally external to the body, without which there would be no disease. In the late 19 th century it was discovered that some infectious agents could pass through very fine filters, known as ultrafilters. The extremely small size was attributed to the tobacco mosaic virus by Ivanovski in 1892 in his filtration experiment and again in 1898 by Beijerinck in his diffusion test. Likewise in 1898 Friedrich Loeffler and Paul Frosch reported the etiological agent of foot-and-mouth disease to be filterable. These reports were soon to be followed by a plethora of publications about other so-called filterable viruses. ${ }^{2}$

Besides filterability, two other properties were apparently shared by most of filterable viruses. Firstly, these agents were invisible under the normal light microscope. Secondly, these filterable viruses did not seem open to cultivation in artificial culture media. The use of solid media was considered important for isolating and typing the various bacterial strains, as well as for obtaining pure bacterial cultures. ${ }^{3}$ The impossibility of growing filterable viruses in artificial media imposed serious limitations on the study of such infectious agents.

1. On the history of the germ theory in general and bacteriology in particular see P. A. Richmond, 'The Germ Theory of Disease', in Times, Places, and Persons: Aspects of the History of Epidemiology, edited A. M. Lilienfeld, Baltimore, Johns Hopkins University Press, 1980, pp. 8493; see also the literature on the history of bacteriology in footnote 12 of Chapter 1 of the present study

2. S. S. Hughes, The Virus: A History of the Concept (London, Heinemann Educational Books, 1977) p. 76. See also Selected Papers on Virology, edited N. Hahon, Englewood Cliffs, N.J., Prentice-Hall, 1964 and Chapter 7 of the present study.

3. In the second half of the 19 th century Robert Koch introduced important basic techniques for studying bacteria. For instance, the use of solid culture media and 'hanging drop' culture methods, coloring techniques and photomicroscopy; see T. D. Brock, Robert Koch: A Life in Medicine and Bacteriology, Madison, WI, Science Tech Publishers, 1988 
The general fact that the filterable viruses seemed to resist cultivation in vitro was confronted with incidental successes. These ambiguous results fostered years of discussion about whether parasitism is obligatory for filterable viruses or not. Growing bacteria in lifeless media had taught that success depended on the use of the proper media with the necessary nutrients. If filterable viruses could not be grown in vitro, this could always be blamed on a lack of adequate techniques. In 1902 Eugenio Centanni could not grow the filterable virus of fowl plague in artificial media and he commented: "The present failure was natural since we have been confronted with an until now unknown world, for which the technique still has to be created. ' 4

But the properties of being filterable and invisible were not the self-evident general properties of a new category of infectious agents such as one might have hoped. Filtration appeared to be dependent on several factors: the pore size of the filter, the filter's absorption properties, the amount of extraneous material in the suspension, the duration of the filtration, the pressure employed, and the temperature at which the filtration was carried out. Some agents could pass through coarse ultrafilters but were retained by fine ones. Moreover, with the introduction of the ultra-violet microscope large filterable agents could be made visible.

Despite the uncertainties that surrounded this research, generally speaking, in the 1920 s and 1930 s filterable viruses were characterized by three properties. To cite Thomas M. Rivers, the Nestor of American virology: 'Viruses are usually characterized by three negative properties, namely invisibility by ordinary microscopic methods, failure to be retained by filters impervious to well-known bacteria, and inability to propagate themselves in the absence of susceptible cells. ${ }^{5}$ With the properties of being filterable and invisible, and because they could not be grown in vitro, filterable viruses were distinguished from other infectious agents. Furthermore they were distinguished from lifeless disease causing agents (e.g. toxins) by their ability to multiply themselves when they invade a susceptible organism. Consequently

4. E. Centanni, 'Die Vogelpest. Beitrag zu dem durch Kerzen Filtrierbaren Virus', Central. blatt für Bakteriologie, Parasitenkunde und Infektionskrankheiten, Abt. I, Orig.. 31 (1902) 145152,182-201:187. (Fowl plague virus is now classified with human influenza viruses as orthomyxoviruses, In a discussion on filterable viruses John M'Fadyean wrote in 1908: 'Assuming that these viruses are bacterial in their nature, one has great difficulty in understanding. why this [the resistance to be grown in artificial media] should be so, for one does not see why the ability of a bacterium to grow under artificial conditions should in any degree be dependent upon its size, 'See J. M'Fadyean. 'The Ultravisible Viruses', Journal of Comparative Pathology and Therapeutics, 21 (1908) 58-68,168-75,232-242:240-241.

5. T. M. Rivers, 'The Nature of Viruses', Physiological Reviews, 12 (1932) 423-452:423. 
it appeared that filterable viruses constitute a separate category within nature.

However, that filterable viruses could theoretically be distinguished from bacteria by certain properties did not mean that they were studied in a different way. In my opinion the filterable viruses which infect man and animals were considered to be small bacteria or 'ultrabacteria' and this presupposition had a great influence on how research was carried out. ${ }^{6}$

To begin with, I will describe the quest for the etiological agent of human influenza. This is followed by a description of the research that led to the claim that in influenza a filterable agent is involved. I will argue that for years after the discovery of the filterable human influenza virus in 1933, until well into the 1940 s, research on influenza virus was performed in accordance with a paradigm derived from bacteriology. I will then go on to demonstrate how the accumulation of anomalies vis-à-vis the bacteriological paradigm for animal viruses in general and the influenza virus in particular, in the late 1940 s led to the articulation of the "modern concept of virus". Regretfully the research that established these anomalies can only be discussed briefly. ${ }^{7}$

\subsection{PFEIFFER'S BACILLUS}

For centuries influenza has been an important cause of death and disease. In Western Europe for the following years severe influenza epidemics were recorded, some of which raged on a pandemic scale: 1562, 1580-1582, 1675, 1733, 1743, 1782, 1833, $1847,1890-1893,1918-1919,1957$ and 1968. Deaths around the world during the influenza pandemic of 1918-1919, following the slaughter of the First World War, are estimated at anywhere between twenty and one hundred million. ${ }^{8}$ The scientific and practical results of bacteriology had impressed the world with Louis Pasteur, Robert

6. Current opinion that viruses can be distinguished from other organisms as well as genetic material leads easily to the conclusion that the filterable viruses were studied as a separate category since their recognition in the late 19th century. Cf. Chapter 7 of the present study.

7. The new concept of vins would become the basis for the differentiation between viruses on the one hand and other organisms and genetic material on the other. An explicit expression of the 'modern concept of virus' was formulated by André Lwoff in 1957 in A. Lwoff, 'The Concept of Virus. The Third Marjory Stephenson Memorial Lecture', Journal of General Microbiology, 17 (1957) $239-253$

8. K. D. Patterson, Pandemic Influenza 1700-1900. A Study in Historical Epidemiology, Totowa, N. J., Rowman \& Littlefield, 1986; F. M. Burnet, 'Portraits of Viruses: Influenza Virus A', Intervirology, 11 (1979) 201-214; A. W. Crosby, America's Forgotten Pandemic: The Influenza of 1918 (first published as Epidemic and Peace, 1918). Cambridge, Cambridge University Press, 1989. 
Koch and Joseph Lister being well-known pioneers of this (medical) science. ${ }^{9}$ Given the high esteem this new science was held in, it is not surprising to find the world during the pandemic of 1890-1893 cherishing high hopes that the dreadful disease with its potentially high mortality rate might be beaten.

The first problem that confronted bacteriologists during that influenza pandemic was to track down the etiological agent of the disease. As a method for pursuing such a quest, one normally subscribed to "Koch's postulates". In a recent biography of Robert Koch it is stated that these 'postulates' were formulated for the first time as three compulsory requirements by Friedrich Loeffler in December 1883:

If diphtheria is a disease caused by a microorganism, it is essential that three postulates be fulfilled. The fulfillment of these postulates is necessary in order to demonstrate strictly the parasitic nature of a disease: 1) The organism must be shown to be constantly present in characteristic form and arrangement in the diseased tissue. 2) The organism which, from its behavior appears to be responsible for the disease, must be isolated and grown in pure culture. 3) The pure culture must be shown to induce the disease experimentally. ${ }^{10}$

However, applying these 'rules' in tracing an etiological agent is much more complex than these simple statements suggest. " Some typical difficulties encountered were: (a) it is not at all evident how to decide who is ill and who is healthy; (b) often the presence of a microbial agent is used as the criterium to decide whether a person has the disease, but this makes the first 'postulate' tautological; (c) there can be carriers of a microbe who do not show disease symptoms; (d) the technique of culti-

9. See, for instance, E. Metchnikoff, The Founders of Modern Medicine: Pasteur, Koch, Lister, New York, Walden Publications, 1939; Microbiology: Historical Contributions from 1776 to 1908, edited R. N. Doetsch, New Brunswick, Rutgers University Press, 1960; T. D. Brock, Milestones in Microbiology, Englewoods Cliffs, N. J., Prentice-Hall, 1961; P. F. Clark, Pioneer Microbiologists of America, Madison, University of Wisconsin Press, 1961.

10. F. Loeffler, 'Untersuchung über die Bedeutung der Mikroorganismen für die Entstehung der Diphterie beim Menschen, bei der Taube und beim Kalbe', Mittheilungen aus dem Kaiserlichen Gesundheitsamte, 2 (1884) 421-499:424; this translation originates from T. D. Brock (footnote 3), p. 180 .

11. L. S. King, 'Dr. Koch's Postulates', Journal of the History of Medicine and Allied Sciences, 7 (1952) 350-361; J. Lennox, 'Those Deceptively Simple Postulates of Professor Robert Koch', The American Biology Teacher, 47 (1985) 216-221. As is underlined in recent work in the sociology of science, rules or instructions do not prescribe how they have to be applied which gives rise to interpretive flexibility in the experimental sciences. See, for instance, H. M. Collins, Changing Order: Replication and Induction in Scientific Practice, London, Sage, 1985 
vating a presumed etiological agent is not always available; (e) when a microbe is isolated, grown in pure culture and inoculated in an experimental animal, the animal often shows other symptoms than those which are observed in the naturally occurring infection. We will see that most of these issues had to be dealt with in the search for the agent of influenza.

Despite the high expectations people had for bacteriology, influenza had already been taking its toll for two years in a row when, in 1892, Richard Pfeiffer published his claim that he had isolated the cause of this disease. Pfeiffer too stated that the second of "Koch's postulates" had to be fulfilled before one could assign an etiological role to the concerned agent. It was required "to prove by growing them that these microorganisms in all cases belong to a well established species and therefore have to be regarded as specific microbes.' 12 In influenza patients Pfeiffer observed rodlike bacterial structures but he did not succeed in cultivating them in normal media. At last he discovered that the addition of blood, or rather haemoglobin alone, was essential for growing these microbes in normal bacteriological media.

For a long time many medical men accepted Pfeiffer's claim that the agent of influenza had been discovered. The microorganism became known as Pfeiffer's bacillus and later on as Haemophilus influenzae. However, it was thought to be strange that Pfeiffer's bacillus, abundantly present in many patients, had not been reported before Pfeiffer published his observations in 1892. This was only one of the questions that would animate the fierce discussions around the cause of influenza during the next forty years.

\subsection{THE INFLUENZA PANDEMIC OF 1918}

The influenza pandemic which broke out in several parts of the world in the spring of 1918 , reached its peak of devastation by the autumn of that year. ${ }^{13}$ When the epidemic began, it was thought that any remaining doubts about the etiological role of Pfeiffer's bacillus would soon be dispelled. On the other hand, if a causal role could not be confirmed, then at least it might be possible to disprove such an etiological role. In the end, however, the many scientific studies resulted in total confusion concerning the etiology of influenza. This is apparent from Robert Donaldson's 174 page contribution to a collection of essays on influenza in 1922. In this essay The Bacteriology

12. R. Pfeiffer, 'Vorläufige Mittheilungen über die Erreger der Influenza', Deutsche Medizinische Wochenschrift, 18 (1892) 28; R. Pfeiffer, 'Die Aetiologie der Influenza', Zeitschrift für Hygiene und Infektionskrankheiten, 13 (1893) 357-386:360.

13. A. W. Crosby (footnote 8). 
of Influenza - With Special Reference to Pfeiffer's Bacillus Donaldson attributed the rapid general acceptance in the 1890 s of Pfeiffer's bacillus as the cause of influenza to the desire for a clear assignable agent:

Incredulous of and disappointed with the claims so far advanced [during the epidemic of 1890/1], the medical world was in a receptive mood, ready to accept as 'causal' any organism which could claim the distinction of being new to bacteriology, even though its constant relationship to the disease could not be proved. ${ }^{14}$

Donaldson noted that it was unjustified to attribute the discovery of Pfeiffer's bacillus to a technical breakthrough, i.e. the addition of haemoglobin to the culture medium. The finding of this 'growth factor' followed the isolation of the microbe. The fact that large quantities of Pfeiffer's bacillus were observed in the latest influenza epidemic could be used as the strongest argument for and against proof of a causal relationship: the presence of influenza seemed to be associated with the microbe, but it was not explained why Pfeiffer's bacillus had not been observed before 1892. ${ }^{15}$

In Donaldson's contribution one immediately recognizes the difficulties that surround "Koch's postulates", referred to in general terms in the previous section. According to Donaldson a patient could only be diagnosed with certainty by using bacteriological techniques: ‘... speaking at least as a bacteriologist, that in the pandemic period the only rational method of differentiating the synchronous cases of somewhat similar clinical form is to classify them in terms of the causal bacteriological agents. ' ${ }^{6}$ However, the effect was that the first 'postulate', i.e. presence of the microbe in diseased tissue, became tautological. Concerning the transmission of the disease to an experimental animal, the third 'postulate', there were also problems:

14. R. Donaldson, The Bacteriology of Influenza - With Special Reference to Pfeiffer's Bacillus, in Influenza: Essays by Several Authors, edited F. G. Crookshank, London, Heinemann, 1922, pp. 139-313:144.

15. R. Donaldson (footrote 14), p. 145.

16. R. Donaldson (footnote 14), p. 156. Lester King pointed out that before the discovery of the tubercle bacillus by Robert Koch tuberculosis was not a strictly defined disease. With the finding of the bacillus a touchstone became available to judge whether someone had tuberculosis or not: 'Instead of vague standards of tissue structure, such as tubercles or giant cells, Koch offered a precise standard, namely, the identification of the tubercle bacillus. According to this scheme, when the bacilli are identified, the case is one of tuberculosis by definition.' (Italics in the original.) See L. S. King (footnote 11), p. 356 
It may not always be possible to infect any of the lower animals with the organism dealt with because the animal may be, as it is termed, 'naturally immune', or (to put it otherwise) because we do not know exactly how so to expose the animal that it will becorne infected. On the other hand, without reproducing the original 'disease', it may be possible to produce certain lesions and even the death of the animal. But such lesions must not be regarded as necessarily the peculiar sequel to infection by the agent employed. ${ }^{17}$

Donaldson ended his long exposé with the statement that Pfeiffer's bacillus could not be the cause of influenza. But as he also concluded that ' $[\mathrm{t}]$ here is not the slightest shred of evidence that the disease is due to a so-called filter-passing virus', he was left with the question of whether influenza was caused by a living organism at all. Was it not possible that there was a kind of disposition to the disease? To be certain about the infectious nature of the disease, Donaldson concluded, epidemiologists had to answer the question whether influenza spread itself along the 'lines of communication'. But if it would become clear that influenza did not behave as an infectious disease, then it would be possible that those different bacteria that were seen in the lesions were nothing more than the immediate causes of the clinical features. ${ }^{18}$

Furthermore, besides the uncertainty about a good experimental animal model and the precise clinical picture of influenza, Pfeiffer's bacillus also seemed to be very variable. The common bacteriological techniques were not suitable to pinning down the microbe:

Opinions [in 1920] were about equally divided as to whether the 'influenza bacillus' could be considered the cause of 'influenza' or not, and it was generally felt that the problem would be easier to solve if both the bacillus and the disease could be more closely delimited and defined. ${ }^{19}$ (Italics mine.)

17. R. Donaldson (footnote 14), p. 158. It is supposed that Streptococcus pneumoniae is causing lobar pneumonia in man and when a culture of this bacterium is introduced in the abdominal cavity of a mouse the animal will die because of this infection. However, death of the mouse is not lobar pneumonia but inflammation of the peritoneum (peritonitis). Thus King stated: "The pneumococcus is indeed pathogenic for the mouse, killing the animal quite rapidly, but the mouse, in succumbing, does not reproduce the human disease.' (Italics in the original.) See L. S. King (footnote 11), p. 358 .

18. R. Donaldson (footnote 14), pp. 235-236.

19. Cited in F. G. Crookshank', 'Chapter I: Method and Thought', in F. Crookshank (footnote 14). pp. $1-10: 10$. 
In the authoritative multi-volume work A System of Bacteriology in Relation to Medicine published from 1929 to 1931 by the English Medical Research Council, more than sixty pages were devoted to the 'Influenza Group of Bacteria'. The problems that were met in the experimental work on influenza are reflected in the following quotation:

... one must provide a set of susceptible human subjects free from lurking infection, must maintain them in infection-proof surroundings during the course of the experiment, and, should the inoculation appear successful, must convey the disease to a similar set or sets of subjects with similar material from the first set. ${ }^{20}$

By this time many bacteriologists had doubts about the role of Haemophilus influenzae as the etiological agent in influenza. One person who continued to believe in it was Richard Pfeiffer himself as is apparent from his contribution to the First International Congress of Microbiology held in 1930. In face of growing confusion about the role of the Haemophilus influenzae bacillus, Pfeiffer still took a firm stand in favour of the microorganism's etiological importance. ${ }^{21}$

\subsection{FILTERABLE INFLUENZA VIRUS}

The notion that influenza is related to an ultrafilterable virus gained importance with the work of Richard Shope on swine influenza. In 1931 this American scientist published an article in which he claimed to have isolated a filterable virus that plays a role in the etiology of that disease. After intranasal administration in swine this filterable agent produced a certain 'filtrate disease', i.e. a mild disease without fever and of short duration. However, when in addition to this the bacillus Haemophilus influenzae-suis was administered along the same porte d'entrée, susceptible animals developed a disease that was clinically and pathologically identical with typical swine influenza. ${ }^{22}$ The work of Shope guided three English scientists who took up the search for a filterable virus in human influenza.

In 1933 Wilson Smith, Christopher Andrewes en Patrick Laidlaw published their findings that human influenza is caused by a filterable virus without the necessity of a

20. W. M. Scott, 'The Influenza Group of Bacteria', in A System of Bacteriology in Relation to Medicine; Volume 1l, Medical Research Council, London, HMSO, 1929, pp. 326-387:353.

21. R. Pfeiffer, 'Die Aetiologie der Influenza', in Premier Congres International de Microbiologie, edited R. Dujarric de Rivière et al., Paris, Masson, 1931, pp. 463-486.

22. R. E. Shope, 'Swine Influenza. III. Filtration Experiments and Etiology', Journal of Experimental Medicine, 54 (1931) 373-385. 
co-infection with a bacterium. During an influenza epidemic these three researchers at the National Institute for Medical Research inoculated different kinds of animals with filtered throat-washings of influenza patients. Besides rats, mice, rabbits and other animals, the ferret was also inoculated through different routes of administration. The ferret was involved because it was considered a useful and more easily handled experimental animal than the dog in the work on 'dog distemper' which was carried out in the Institute at the time. When filtered throat-washings were introduced into the nose of a ferret, the animal appeared to be susceptible and fell ill with typical symptoms of influenza. The disease was diagnosed as influenza on the basis of the clinical picture, the pathological findings and serum neutralisation tests. Sera of patients who had recovered from influenza were able to neutralise filtered infectious throat-washings. When Shope's swine influenza virus was introduced intranasally into the ferret, a disease developed that could not be distinguished from the disease caused by a filtrate of human origin. Cross immunity tests showed influenza virus from pigs to have strong antigenic similarities to the filterable agent isolated from patients. ${ }^{23}$

In their first experiments Laidlaw and his co-workers were not able to transmit the disease to mice but a new experimental procedure made this possible. In the meantime Shope had published work in which he had inoculated ferrets under ether anaesthesia. By using this technique the English scientists could infect mice with human influenza virus. In 1934 Andrewes, Laidlaw and Smith announced that they had infected mice with human as well as swine influenza virus. Substituting mice for ferrets as experimental animals for influenza research was an important breakthrough because this made experiments much more easy. ${ }^{24}$

The claim of the English researchers that they had discovered an etiological role of a filterable virus in human influenza soon received support from many quarters. With these successful experimental models scientists from all over the world reported the isolation of human influenza viruses. Viral material was obtained by grinding an infected mouse's lung with sand and saline and filtering the suspension. Neutralisation

23. W. Smith, C. H. Andrewes and P. P. Laidlaw, 'A Virus Obtained from Influenza Patients', Lancet, ii (1933) 66-68; Sir C. Andrewes, 'Recollections', in International Virology: First International Congress of Virology, edited J. L. Melnick, Basel, Karger, 1969, pp. 220-223; A. W. Crosby (footnote 8), pp. 285-290. The 'Studies in Dog-Distemper' by G. W. Dunkin and P. P. Laidlaw were published as three papers in the Journal of Comparative Pathology and Therapeutics, 39 (1926) $201-230$.

24. R. E. Shope, 'The Infection of Ferrets with Swine Influenza Virus', Journal of Experimental Medicine, 60 (1934) 49-61; C. H. Andrewes, P. P. Laidlaw and W. Smith, 'The Susceptibility of Mice to the Viruses of Human and Swine Influenza', Lancet, ii (1934) 859-862. 
tests with convalescent serum were used to identify the virus. In 1934 Francis $J_{r}$. isolated virus strains during epidemics in Puerto Rico and Philadelphia; Burnet isolated a strain in Australia while Pettit, Mudd and Pepper obtained one from Alaska. In 1936 further isolations were reported from Leningrad and New Haven. Neutralisation tests showed that all these human influenza virus strains were antigenically identical but differed from swine influenza virus. ${ }^{25}$

The immunological homogeneity of human influenza virus was questioned by Thomas Francis Jr. in 1940. He had isolated a LEE-strain of influenza virus (named after the patient from whom the virus was isolated) which did not conform to the identification criteria of the known influenza viruses. Besides the above mentioned neutralisation test, serology also had another standard test, the so-called complement fixation test (CFT). ${ }^{26}$ Using the CFT it was possible to distinguish the LEE-strain from the human influenza virus strains which had been isolated earlier. Francis Jr. concluded that LEE influenza virus was a serologically specific entity (this virus was designated as influenza $B$ virus) whereas the influenza viruses that had been isolated previously (swine, human WS and human PR8) were designated as influenza A virus. ${ }^{27}$

\subsection{MANIPULATING THE INFLUENZA VIRUS}

Growing influenza virus in animals like the ferret and the mouse proved suitable for the isolation and subsequent immunological identification of viruses during epidemics. For further laboratory studies, however, these experimental models were less appropriate. In the mid 1930 s an important breakthrough came with a technique developed by Macfarlane Burnet and based on the work of Ernest Goodpasture and Alice Woodruff. These last two workers had grown fowl pox virus on the chorio-

25. L. Hoyle, The Influenza Viruses; Virology Monographs Vol. 4, Vienna, Springer, 1968, p. 10; information on different laboratory strains of influenza virus is found on pp. 21-23.

26. In such a test the presence of virus antigen is shown by the removal (fixation) of nonspecific complement by antiserum against the virus antigen. Presence or absence of complement can be shown by a 'hemolytic system'. When blood cells lyse, complement was not fixed in the first reaction (absence of virus antigen); if blood cells do not lyse, complement was fixed in the first reaction (presence of virus antigen). See, for instance, A. Dieudonné, Immunität, Schutzimpfung und Serumtherapie. Zusammenfassende Übersicht über die Immunitätslehre, 8th edition, Leipzig, J. A. Barth, 1913, p. 50.

27. T. Francis Jr., 'A New Type of Virus from Epidemic Influenza', Science, 92 (1940) 405408. In 1950 a strain of influenza virus was isolated that differed from influenza viruses $A$ and $B$ and therefore was designated as influenza C virus; T. Francis Jr., J. J. Quilligan Jr. and E. Minuse, 'Identification of Another Epidemic Respiratory Disease', Science, 112 (1950) 495-497. 
allantoic membrane of the embryonated chicken egg. It appeared to be easy to start the growth of fowl pox virus but it seemed to be crucial to use an inoculate free from contaminating microorganisms. ${ }^{28}$

Burnet, Australian by birth, had worked in England with Christopher Andrewes in the early 1930s and had witnessed the successful isolation of the first human influenza virus. Thus he was aware that influenza virus must be cultured for two to thirteen passages in the ferret before it could be transmitted to mice. Apparently, the human influenza virus had to adapt itself to the new environment, i.e. the ferret, before it became infectious in mice. Back in Australia, Burnet tried to cultivate influenza virus in a chicken embryo following Goodpasture's method. Subinoculations of supposed influenza virus material were carried out by grinding the whole membrane - which forms the basis of an artificial air sack in the embryonated egg - with broth. The emulsion was centrifuged and the supernatant was used for the next inoculation. First subinoculations were performed without visible evidence of the presence of the influenza virus. Only after 30 to 40 serial subinoculations of fresh embryonated eggs with infected membrane emulsions, was the virulence of the influenza virus enhanced. Soon thereafter countable 'spots' or pocks developed on the membrane. Chicken embryos that were inoculated with such an egg adapted influenza virus died with severe brain hemorrhages. Burnet claimed the number of lesions on the chorioallantoic membrane to represent an index for the number of virus particles that was inoculated. 29

Due to the availability of this laboratory technique the influenza virus could more easily be isolated, grown and quantified. Furthemore, despite its adaptation to the egg, the influenza virus appeared to have maintained its immunological properties. Therefore the cultivation method developed by Burnet offered the possibility of making an influenza virus vaccine. ${ }^{30}$

28. A. M. Woodruff and E. W. Goodpasture, 'The Susceptibility of the Chorio-Allantoic Membrane of Chick Embryos to Infection with the Fowl-Pox Virus', American Journal of Pathology, 7 (1931) 209-222. By that time no antibiotics were available that could inhibit the growth of bacteria and therefore the technique had to applied under as sterile conditions as possible; see M. Burnet, 'The Influence of a Great Pathologist: A Tribute to Ernest Goodpasture', Perspectives in Biology and Medicine, 16 (1972/73) 333-347.

29. F. M. Burnet, 'Influenza Virus on the Developing Egg: I. Changes Associated with the Development of an Egg-Passage Strain of Virus', British Journal of Experimental Pathology, 17 (1936) 282-293; F. Burnet (footnote 8); M. Burnet (footnote 28).

30. The egg adapted PR8-strain of the influenza virus, that was isolated by Francis Jr. in 1934, is no longer infectious for humans; see E. D. Kilbourne, Molecular Determination of the Epidemi- 
Besides counting the number of lesions on the chorio-allantoic membrane of a virus-infected chicken egg, quantification of influenza virus was made much more easy by another technique that was worked out in the early 1940s. In 1941 two research articles appeared that contained the same observation. One of the papers was written by George Hirst and the other one by Laurella McClelland and Ronald Hare. Both studies showed that when a suspension of red blood cells was mixed with influenza virus infected allantois fluid, agglutination immediately developed and clumps of red blood cells precipitated. In various techniques the formation of this precipitate, or haemagglutination, could be used as an index for the number of virus particles. ${ }^{31}$

This overview of methods prevalent in laboratories during the $1930 \mathrm{~s}$ and $1940 \mathrm{~s}$ and some of the underlying presuppositions will serve as a basis to argue that during this period influenza virus research was carried out according to a paradigm that can be characterised as 'bacteriological' ${ }^{32}$

\subsection{THE BACTERIOLOGICAL PARADIGM}

There are three main arguments which sustain the claim that a bacteriological paradigm was a major influence in early influenza virus research. Firstly, research was undertaken on the basis of the germ theory of infectious disease where etiological agent and disease were considered as cause and effect. Secondly, the influenza virus was studied primarily as an infectious entity. And finally, multiplication or growth of filterable viruses was believed to be analogous to growth of bacteria, i.e. growth by ology of Influenza: A Reconciliation of Approaches, in The Molecular Virology and Epidemiology of Influenza, edited C. Stuart-Harris and C. W. Potter, London, Academic Press, 1984, pp. $257-$ 267:259.

31. G. K. Hirst, 'The Agglutination of Red Cells by Allantoic Fluid of Chick Embryos Infected with Influenza Virus', Science, 94 (1941) 22-23; L. McClelland and R. Hare, 'The Adsorption of Influenza Virus by Red Cells and a New in Vitro Method of Measuring Antibodies for Influenza Virus', Canadian Public Health Journal (Laboratory Supplement), 30 (1941) 530-538. The agglutination of red blood cells by influenza virus is a phenomenon of which Burnet said he should have discovered it himself; see F. M. Burnet, Changing Patterns: An Atypical Autobiography, Melbourne, Heinemann, 1968, p. 126.

32. I use the notion paradigm not as a concrete puzzle-solution but as 'the entire constellation of beliefs, values, techniques, and so on shared by the members of a given community.' See T. S. Kuhn, The Structure of Scientific Revolutions, 2nd edition, Chicago, University of Chicago Press, 1970 , p. 175. For a discussion on 'paradigm' and literature references see P. T. Durbin, Dictionary of Concepts in the Philosophy of Science, New York, Greenwood Press, 1988, pp. 221-224. 
binary fission. I will comment briefly on each of these points.

The core of the germ theory of infectious disease is the belief that any specific infectious disease is caused by a specific infectious agent. In this way a filterable virus is linked to a specific disease in terms of cause and effect. This complex of a specific agent, a specific disease, and the relation between them as cause and effect can be designated as belonging to the ontological approach to infectious disease. ${ }^{33}$ Bacteriology, in existence as a scientific discipline since the second half of the 19th century, in its methods and assumptions exemplified this approach. The heuristics of "Koch's postulates" were thought valid whether the infectious agent was filterable or not. Therefore the epidemiology of influenza had to match the spread of an etiological agent. That is why Donaldson in 1922 stated that the epidemiology of influenza first had to be established before one could conclude that influenza is an infectious disease. The task of the epidemiologist was, according to Donaldson, to answer the question whether the disease proliferates along the 'lines of communication' or not. ${ }^{34}$

Another important bacteriological characteristic of influenza virus research was that the infectious agent was specified and described on the basis of the clinical picture or the pathological effects found in the infected macroorganism. Thus the Newcastle Disease Virus, which was isolated in 1927, was described as a new specific filterable virus distinguishable from fowl plague virus on the basis of disease symptoms, host specificity, incubation time, specific lesions, immunological characteristics, etc. A few years later Burnet and Ferry differentiated the agents of Newcastle Disease and fowl plague on the basis of the effects of the two viruses on the chorio-allantoic membrane when these viruses are cultured in embryonated eggs. With the establishment of the 'modern concept of virus' in the 1950s, viruses were not classified any longer according to their pathological effects only but also on the basis of their intrinsic properties, i.e. their molecular structure. In 1955 human influenza virus, Newcastle Disease

33. Owsei Temkin opposed the ontological view against the physiological notion of disease. From the ontological view the bacteriologist interpreted a specific infectious disease as caused by a specific microorganism. However, "... the bacteriologist had to visualize the relationship between parasite and host as an interaction, and it was this interaction which manifested itself as the disease.' But "... if the ontologist was rightly challenged by the demand that disease must be understandable as a process of life, the physiologist was challenged to show cause why the endless variations of form and gradations of function should somewhere admit classification as healthy and diseased.' See $O$. Temkin, 'The Scientific Approach to Disease: Specific Entity and Individual Sickness', in $O$. "Temkin, The Double Face of Janus and Other Essays in the History of Medicine, Baltimore, Johns Hopkins Press, 1977, pp. 441-455:443,448.

34. R. Donaldson (footnote 14), pp. 235-236. 
Virus and fowl plague virus were placed in one category, the myxoviruses, on the basis of their molecular properties. ${ }^{35}$

The ontological approach in influenza research assumed that influenza is caused by a specific agent. In case of the influenza virus discovered in 1933, the agent could be multiplied by using newly developed culture techniques and isolated by employing physicochemical techniques. A clear example of such a physicochemical preference in the study of influenza virus was the development of an influenza vaccine by Wendell Stanley, who was already renowned for his crystallisation of tobacco mosaic virus in 1935. Stanley isolated and purified influenza virus by using an ultracentrifuge. ${ }^{36}$ An important assumption underlying his work to create an influenza vaccine was that influenza virus had to be immunologically stable, to some extent, in the laboratory as well as in nature. Only then would it be procedurally rational to prepare influenza vaccines for any future influenza epidemic. The fact that later research showed the influenza virus to be immunologically extremely variable contrasted with the observations made of bacteria in their natural environment. Concepts like genetic variation c.q. mutation were therefore one step further towards developing a virological paradigm.

Besides the effects of the germ theory of infection and the study of influenza virus as specific entity, there is a third level at which influenza virus research was to a large extent shaped by the bacteriological paradigm, namely with regard to the ideas current concerning the multiplication or growth of filterable viruses. It should be remembered that the dependence of filterable virus on living host cells was controversial in the first decades of this century. The reality of this dependence was increasingly acknowledged in the 1920 s and 1930 s so that the problem of virus growth somehow had to be

35. T. M. Doyle, 'Hitherto Unrecorded Disease of Fowls Due to Filterpassing Virus', Journal of Comparative Pathology and Therapeutics, 40 (1927) 144-169; F. M. Burnet and J. D. Ferry, 'The Differentiation of the Viruses of Fowl Plague and Newcastle Disease. Experiments Using the Technique of Chorio-Allantoic Membrane Inoculation of the Developing Egg', British Journal of Experimental Pathology, 15 (1934) 56-64; C. H. Andrewes, F. B. Bang and F. M. Burnet, 'A Short Description of the Myxovirus Group (Influenza and Related Viruses)', Virology, 1 (1955) 176-184.

36. W. M. Stanley, 'An Evaluation of Methods for the Concentration and Purification of Influenza Virus', Joumal of Experimental Medicine, 79 (1944) 255-266; idem, 'The Size of Influenza Virus', idem, 79 (1944) 267-283; idem, 'The Preparation and Properties of Influenza Virus Vaccines Concentrated and Purified by Differential Centrifugation', idem, 81 (1945) 193-218. The physicochemical approach of Wendell Stanley in the study of tobacco mosaic vinus is analysed in $T$. van Helvoort, 'What is a Virus? The Case of Tobacco Mosaic Disease', Studies in History and Philosophy of Science, 22 (1991) 557-588; included as Chapter 2 of the present study. 
addressed in connection with this dependency.

The growth problem was also connected with the notions on the nature and origin of the filterable viruses. Robert Green, a naturalist-turned-doctor, maintained that two hypotheses offered reasonable explanations for the origin of filterable viruses. The first option was that these infectious agents, which appeared to Green to be dependent on living host cells, originally developed themselves from saprophytic ultramicrobes, that is to say, derived from (ultra)filterable microbes that were not dependent on host cells for their multiplication. As such microbes could not be found in nature, one had to assume that these saprophytic ultramicrobes had become extinguished. The second possibility was that filterable viruses originated by 'retrograde evolution', i.e. an evolutionary process in which the organism lost its functions and became more and more simple. Following this hypothesis, filterable viruses were descendents of visible microbes that currently inhabited the world. ${ }^{37}$

The idea of a loss of functions or factors for independent growth in an evolutionary process, with consequent reduction of size, offered a hypothesis for the origin of filterable viruses that also appealed to Patrick Laidlaw. ${ }^{38}$ Such a development could account for the smallest viruses which had lost all ferments and autosynthetic capabilities. This hypothesis about the origin of (filterable) viruses by retrograde evolution became known as the Laidlaw-Green hypothesis.

For my argument the origin of viruses is less relevant than the conclusion that was to be drawn from it. After accepting that filterable viruses developed from bacteria by loss of function, it was only a small step to go on to conclude that (filterable) viruses multiply by the same process as bacteria do, i.e. by division or binary fission. It had been known for a long time that a bacterium multiplies by increasing in size and subsequently dividing into two identical daughter cells. The dependence of filterable viruses on living cells initially did not make bacteriologists conclude that there is a fundamental difference between the multiplication of bacteria and that of filterable viruses. An illustration of this opinion can be found in the following quotation from Thomas Rivers from 1928: 'A satisfactory explanation of the difficulty experienced in cultivating the viruses in artificial media is not easily found. Their small size alone should not make them insusceptible to cultivation. ' 39

37. R. G. Green, 'On the Nature of Filtrable Viruses', Science, 82 (1935) 443-445.

38. P. P. Laidlaw, Virus Diseases and Viruses, Cambridge, Cambridge University Press, 1938. Laidlaw was the senior author of the 1933 Lancet-article in which the discovery of influenza virus wis claimed.

39. T. M. Rivers, Some General Aspects on Filterable Viruses, in Filterable Viruses, edited 
Until late in the 1940s growth and multiplication were used as synonyms within bacteriology. In 1949 the phage researcher Seymour Cohen suggested that for bacteria growth is not identical to multiplication but he thought the interchange of the concepts multiplication and growth was acceptable for (bacterial) viruses. The awareness that division as such has nothing to do with growth but with survival would be one of the important building blocks of the 'modern concept of virus'. It is in this context that Salvador Luria wrote in 1950: 'In many minds the terms reproduction and selfreproduction are connected with the idea of increase in size followed by division. Closer scrutiny reveals that increase in size followed by division is bound to be an epiphenomenon of some critical event of reproduction ...' (Italics in the original.) In the 1950 s one came to speak of virus replication. 40

Let me sum up the most important characteristics of the work on filterable viruses that infect man or animals - and human influenza viruses in particular - in the $1930 \mathrm{~s}$ and 1940s. These are: (a) the bacteriological paradigm used the core of the germ theory of infectious diseases, i.e. a causal relation between the infectious agent and the infectious disease; (b) this causal understanding found an expression in the assumption on the spread of the virus and the epidemiology of infectious disease along the lines of communication; (c) the quest for an infectious etiological agent was carried out in the terminology of Koch's postulates; (d) typifying viruses was based upon the effect level of these agents, i.e. host specificity, incubation time, disease symptoms, specific lesions, etc; (e) immunological techniques supplemented these data: the parameters studied were cross-immunity, neutralisation tests, complement fixation test, etc.; (f) viruses could be studied in the laboratory and the information thus obtained would be useful for combating infectious disease 'in the field'; implicit was the notion that viruses had stability in nature; $(\mathrm{g})$ viruses were degenerated bacteria; this hypothesis legitimated the presupposition that viruses multiplied by binary fission as do bacteria.

T. M. Rivers, London, Baillière, Tindall \& Co., 1928, pp. 3-52:13.

40. S. S. Cohen, 'Growth Requirements of Bacterial Viruses', Bacteriological Reviews, 13 (1949) 1-24:1; S. E. Luria, 'Bacteriophage: An Essay on Virus Reproduction', Science, 111 (1950) 507-511:507; see also Chapter 6 of the present study. The questioning of the identity of growth and multiplication for influenza virus was, for example, discussed in L. Hoyle, The Multiplication of the Influenza Virus Considered in Relation to the General Problem of Biological Multiplication, in The Nature of Virus Multiplication - Second Symposium of the Society for General Microbiology, edited P. Fildes and W. E. van Heijningen, Cambridge, Cambridge University Press, 1953, pp. 225243. 
During the second half of the 1940s influenza virus researchers were confronted with several important observations that shed doubts on some of their assumptions mentioned above. The validity of the bacteriological paradigm came to be questioned. A first critical impulse came from the failure of immunisation experiments in 1946 and 1947. In the preliminary report of this vaccination experiment it was concluded that '... absence of effect of vaccination during the outbreak of influenza in the spring of 1947 appears to be due to the lack of sufficient antigenic crossing between the strains of virus in the vaccine and the prevalent strain responsible for the epidemic.' ${ }^{41}$ This led one to conclude that the influenza virus was much more variable than one had assumed. This recognition contributed to the acceptance of an ecological approach in studying the influenza virus problem, an approach vigorously defended by Macfarlane Burnet.

In his Virus as Organism Burnet pointed out that viruses could be studied in two different ways. ${ }^{42}$ Some disciplines studied the organism in isolation and were engaged in illuminating the chemical and morphological structure of viruses and their functioning as independent and individual units. This is what I would call the ontological way of studying viruses. Burnet contrasted these methods with a study of organisms in their natural environment: the ecological approach.

According to Burnet the relation between virus and host could not be an antagonistic one. If a pathogenic agent - be it a bacterium, a virus or something else were considered as a living organism, then its existence and the continuous survival of host and agent could not depend on antagonism. Since this antagonism would imply destruction of either the host or the parasite, Burnet argued that a balanced relationship between parasite and host during variable periods of time had to be the rule. I would like to reformulate this statement to argue that the ontological approach in which the relationship between virus and host was interpreted as cause and effect, had only limited validity. The substitution, to a certain extent, of the ecological approach for the ontological approach and the impact of the vaccination failure of 1947, are apparent from the following quotation of influenza expert Leslie Hoyle:

41. T. Francis $J_{r}$., J. E. Salk and J. J. Quilligan Jr., 'Experience with Vaccination Against Influenza in the Spring of 1947. A Preliminary Report', American Journal of Public Health, 37 (1947) 1013-1016:1016.

42. F. M. Burnet, Virus as Organism: Evolutionary and Ecological Aspects of Some Human Virus Diseases. E. K. Dunham Lectures 1944, Cambridge, Mass., Harvard University Press, 1945, p. 28 
By 1946 it seemed probable that with further development of methods of purifying and concentrating virus and by the use of recently isolated strains protective vaccination might play an increasingly useful role in the control of influenza. These hopes were shattered in 1947 - a year which proved a turning point in influenza research. (...) The failure of the vaccination campaign in 1947 stimulated studies on the epidemiology of influenza and on variation in influenza viruses. 43

Another element that contributed to the emancipation of virus research from the bacteriological paradigm came from the laboratory. Several research teams drew the conclusion that during the influenza virus' growth the virus temporarily disappeared as an infectious entity. It was concluded by Hoyle that when influenza virus entered a host cell it disintegrated. As he wrote in 1948 the influenza virus could occur in two forms, i.e. an extra-cellular infectious particle and an intra-cellular multiplying form in which the virus was not infectious. Later on the disappearance of infectious influenza virus during its multiplication became known as the 'eclipse' of the influenza virus. This view was consistent with the results of a study by Werner and Gertrude Henle published in 1949.44

The pervasiveness of the bacteriological paradigm for influenza virus research until the late 1940 s is to my opinion characteristic for the research of most animal viruses during this period. Its influence was less for those viruses that infect bacteria and plants. The intrinsic properties of these viruses seemed more appropriate to the field of biochemistry and physical chemistry than bacteriological research. ${ }^{45}$ The importance of the analogy between viruses and bacteria, especialiy for those who studied animal viruses, was also perceived by Leslie Hoyle who wrote in his monograph on influenza

43. L. Hoyle (footnote 25), p. 11 and p. 15.

44. L. Hoyle, 'The Growth Cycle of Influenza Virus A. A Study of the Relations between Virus, Soluble Antigen and Host Cell in Fertile Eggs Inoculated with Influenza Virus', British Journal of Experimental Pathology, 29 (1948) 390-399; idem, 'The Multiplication of Influenza Viruses in the Fertile Egg', Journal of Hygiene, 48 (1950) 277-297; 'Structure of the Influenza Virus. The Relation between Biological Activity and Chemical Structure of Virus Fractions', idem, 50 (1952) 229-245. The work of Werner and Gertrude Henle is summarized in W. Henle, 'Multiplication of Influenza Virus in the Entodermal Cells of the Allantois of the Chick Embryo', Advances in Virus Research, 1 (1953) 141-227

45. The research on animal viruses differed from that on bacterial and plant viruses. In the latter two cases, those using ontological approaches quareled with those using physiological approaches for validity. For a definition of ontological and physiological approaches see Temkin (footnote 33). Cf. Chapter 7 of the present study. 
viruses:

Before 1948 it was almost universally believed by animal virus workers that viruses had evolved from bacteria by a process of increasing parasitism, adopting an intracellular habitat and gradually losing their enzymes until they became completely dependent on the host cell, only retaining the ability to multiply by some process of growth and fission. This was the Laidlaw-Green hypothesis. It had never been accepted by plant virologists who had long regarded viruses as protein molecules, or by bacteriophage workers who had tended to regard phages as self reduplicating enzymes or genes. In spite of this the Laidlaw-Green hypothesis was supported with a fervour more appropriate to a religious dogma than a scientific theory. 46

The dismissal of the Laidlaw-Green hypothesis for the influenza viruses meant that the heart was taken out of the validity of the bacteriological paradigm for virus research. In the end - together with developments in research on bacterial and plant viruses - this would result in the formulation of the 'modern concept of virus' in the 1950s. In 1957 André Lwoff arrived at a definition of a virus which demarcated viruses from organisms, genetic material and organelles endowed with genetic continuity. ${ }^{47}$ The 1950 s marked the maturing of a virological paradigm with which the study of viruses truly emancipated from bacteriology.

46. L. Hoyle (footnote 25), p. 13

47. A. Lwoff (footnote 7). pp. 245-246; cf. Chapter 6 of the present study. 
CHAPTER 4

Bacteriological and Physiological Research Styles in the Early Controversy on the Nature of the Bacteriophage Phenomenon

CONTENTS

4.1 'Discovery' of the bacteriophage phenomenon $\mathbf{8 1}$

4.2 Priority dispute and reification of bacteriophagy 84

4.3 D'Hérelle's interpretation further criticized $\mathbf{8 9}$

4.4 Félix d'Hérelle and the bacteriophage: a bacteriological style 93

4.5 Following in Louis Pasteur's footsteps 97

4.6 Jules Bordet, transmissible bacterial lysis and immunity $\mathbf{1 0 0}$

4.7 Jules Bordet and the bacteriophage: a physiological style $\mathbf{1 0 5}$

4.8 The constraining force of research styles $\mathbf{1 1 1}$

Adapted from

Medical History, vol. 36 (1992), pp. 243-270. 


\section{CHAPTER 4}

\section{Bacteriological and Physiological Research Styles in the Early Controversy on the Nature of the Bacteriophage Phenomenon}

Historians and sociologists of science take a lively interest in research styles as an analytical concept. ${ }^{1}$ Using the concept of style is a way of emphasizing the role of continuity and tradition in the development of science. To quote Thomas Kuhn, "only investigations firmly rooted in the contemporary scientific tradition are likely to break that tradition and give rise to a new one". ${ }^{2}$ On the other hand, the concept of research style is used to argue that there are different and often competing approaches within disciplines, frequently based in research groups or research schools. ${ }^{3}$

The concept of style, now in the form of "thought style", also came into vogue by the translation and republication of Ludwik Fleck's Entstehung und Entwicklung einer wissenschaftlichen Tatsache in which he argued that scientists' observations and their definitions of "facts" are shaped by the thought styles or assumptions shared by "thought collectives". Concepts are supposed to derive their meaning from the existence of a stylistic bond between them, so the thought style determines the formulation of every concept. ${ }^{4}$

1. The concept of style was borrowed from the fine arts, where it refers to cultural patterns. See for instance Emst H. Gombrich, 'Style', in International encyclopedia of the social sciences, ed. David L. Sills, New York, Macmillan \& Free Press, 1968, pp. 352-61.

2. Thomas S. Kuhn, The essential tension: selected studies in scientific tradition and change, University of Chicago Press, 1977, p. 227. For a compilation of attempts to describe continuity and discontinuity in the development of science see, for instance, Ian Hacking (ed.), Scientific revolutions, Oxford University Press, 1981 and also Chapter 7 of the present study.

3. For literature on research styles and research schools see Chapter 1 of the present study.

4. Thaddeus J. Trenn and Robert K. Merton (eds), Ludwik Fleck: genesis and development of a scientific fact, University of Chicago Press, 1979; Robert S. Cohen and Thomas Schnelle (eds), Cognition and fact: materials on Ludwik Fleck, Dordrecht, Reidel, 1986. The parallel between Fleck's thought collectives and thought styles, and Kuhn's scientific communities and paradigms will be evident.

The existence of a tradition or style in science and its normative role is not easily recognized by most working scientists themselves, although there are exceptions. The renowned virologist and immunologist Macfarlane Burnet wrote that "Scientific work is of value insofar as it is carried out in 
In reviewing recent work inspired by Fleck's ideas, Jonathan Harwood has stated that the concept of thought style can only be used analytically to aid the historian in describing history, but is without any explanatory power. ${ }^{5}$ This conclusion contradicts Fleck's claim that a thought style forces the further development of scientific knowledge into certain directions. In other words, there are limitations to the theoretically limitless variability and negotiability of observations and theoretical notions. In a discussion of the "constraining force" of a thought style, Cohen and Schnelle maintained that Fleck claimed that the thought style structures the working practice of the thought collective, i.e. "both what can and must be considered as a scientific problem, and how this problem is to be dealt with", ${ }^{6}$ [Italics in the original.]

In this essay I will discuss a controversy which developed in the 1920 s on the nature of bacteriophages, which are at present conceived of as bacterial viruses. The bacteriophage phenomenon was the observation that an abundant and therefore cloudy bacterial culture lysed within a short time to a clear solution under the influence of a filterable lytic "principle". The interpretation of this phenomenon gave rise to two main opposing positions, represented by Félix d'Hérelle and Jules Bordet, who clashed heavily. In 1917, d'Hérelle proposed the term "bacteriophage" for the lytic principle and was convinced it was to be characterized as a filterable virus which could lyse the bacterial culture. Therefore, this lysis was a virus disease of the bacteria which he named bacteriophagy. In the 1920s this interpretation was severely criticized by, among others, the bacteriologist and serologist Jules Bordet, who received the Nobel Prize for Medicine in 1919. Bordet's view was that bacteriophagy was linked with the metabolism of the bacterium, while the involvement of a virus was rejected.?

accordance with the current tradition of integrity and technical ability and provides results which can be stated in a form that is relevant to the current structure of generalization within the field chosen." See F. Macfarlane Burnet, 'From bacteriophage to influenza virus', in Victor A. Najjar (ed.), Immunity and virus infection. New York, John Wiley \& Sons, 1959, pp. 163-75, on p. 169.

5. Jonathan Harwood, 'Ludwik Fleck and the sociology of knowledge', Soc. Stud. Sci., 1986, 16: $173-87$

6. Robert S. Cohen and Thomas Schnelle, 'Introduction', in Coher and Schnelle, op. cit., note 4 above, pp. ix-xxxiii, on p. $x x$.

7. The history of the research into the nature of the bacteriophage phenomenon is discussed in, among others, Paul C. Flu, 'The bacteriophage: a historical and critical survey of 25 years research', Acta Leid. Scholae Med. Trop., 1946, 17: 15-201; André Lwoff, 'Lysogeny', Bact. Revs, 1953, 17: 269-337; Gunther Stent, Molecular biology of bacterial viruses, San Francisco, W. H. Freeman, 1963; Donna H. Duckworth, 'Who discovered bacteriophage?', Bact. Revs, 1976, 40: 793-802; Alan 
My aim is to show that d'Hérelle and Bordet elaborated their respective positions into consistent interpretational contexts or research styles. Like the constraining force of Fleck's conception of thought style, these research styles exerted a constraining force on what was to be studied and how this had to be done. By describing the controversy in detail, a historical example is given of the way in which two research styles limited the interpretive flexibility of experiments. The controversy shows how a particular research style opened up "facts" for discussion which were "closed" within the competing research style. ${ }^{8}$

Félix d'Hérelle's research style will be designated as "bacteriological" while that of Jules Bordet as "physiological". The use of these terms needs to be explained because they differ from the usual disciplinary denotations. The work of d'Hérelle is called bacteriological because he interpreted the bacteriophage as an autonomous living entity infesting bacteria. In this way, he worked within a "thought collective" which regarded filterable viruses as small bacteria or ultramicrobes. This was a conception which was generally held in the study of animal viruses. I have argued elsewhere that, until the late 1940s, workers on influenza thought of the influenza virus as being in many respects just such ultramicrobes and they worked within a bacteriological paradigm. ${ }^{9}$ But the notion of the nature of a filterable virus as an ultramicroscopic

W. Varley, Living molecules or autocatalytic enzymes: the controversy over the nature of bacteriophage, 1915-1925, Ph.D. Thesis, University of Kansas, 1986; University Microfilms International, no. 8711282; Charles Galperin, 'Le bactériophage, la lysogénie et son déterminisme génétique', Hist. Philos. Life Sci., 1987, 9: 175-224; Thomas D. Brock, The emergence of bacterial genetics, Cold Spring Harbor, N. Y., Cold Spring Harbor Laboratory Press, 1990.

8. The interpretive flexibility of experiments is another term for the Duhem-Quine thesis, which states that a theory is underdetermined by experiment. That is to say, all conclusions drawn from experiments can in principle be challenged. Cf. David Gooding, Trevor Pinch and Simon Schaffer, 'Introduction: some uses of experiment', in idem (eds), The uses of experiment: studies in the natural sciences, Cambridge University Press, 1989, pp. 1-27, especially pp. 11-13; Steven Shapin, 'History of science and its sociological reconstructions', in Cohen and Schnelle, op. cit., note 4 above, pp. 325-86, especially note 12, on pp. 372-3; Jan Golinski, 'The theory of practice and the practice of theory: sociological approaches in the history of science', Isis, 1990, 81: 492-505, on pp. $503-4$

9. Ton van Helvoort, 'A bacteriological paradigm in influenza research in the first half of the twentieth century', Hist. Philos. Life Sci, 1993, 15: in press; included as Chapter 3 of the present study. An important aspect of this bacteriological paradigm is the concept of specific causation of a distinct disease entity (the ontological conception of disease) by a specific etiological agent. $\mathrm{Cf} . \mathrm{K}$. Codell Carter, 'The development of Pasteur's concept of disease causation and the emergence of 
microbe was also current in plant virus research until the 1930s. ${ }^{10}$ The work of Bordet is described as physiological in order to indicate that he approached the problem of the bacteriophage by starting from the bacterium. He interpreted his observations on bacteriophagy (including hereditary aspects) as belonging to the physiology of the bacterium.

The use of the terms bacteriological and physiological research styles in bacteriophage research on the basis of one case study may make it look as if I am jumping to conclusions. However, it will be shown elsewhere that, until the $1950 \mathrm{~s}$, bacteriophage research was structured by two thought styles, viz. an exogenous and an endogenous style. ${ }^{11}$ This points to a strong parallel with Gerald Holton's identification of thema/antithema in the development of the physical sciences. ${ }^{12}$

\section{1 "DISCOVERY" OF THE BACTERIOPHAGE PHENOMENON}

During World War I, Félix d'Hérelle worked at the Pasteur Institute in Paris, where he studied bacillary dysentery. ${ }^{13}$ This form of dysentery, resulting in bloody diarrhoea, was often found in soldiers at the eastern front. ${ }^{14}$ Despite clinical symptoms, the bacteriological diagnosis was often problematic, as dysentery bacilli were not found. In 1903, Emil de Schweinitz and M. Dorset had claimed that swine fever or hog cholera could not be attributed to the hog-cholera bacillus (now known as Salmonella cholerae-suis) alone. In the laboratory, the disease was contagious only when the specific causes in nineteenth-century medicine', Bull. Hist. Med, 1991, 65: 528-48. See also Henk van den Belt and Bart Gremmen, 'Specificity in the era of Koch and Ehrlich; a generalized interpretation of Ludwik Fleck's "serological" thought style', Stud. Hist. Philos. Sci, 1990, 21 : 463-79.

10. Ton van Helvoort, 'What is a virus? The case of tobacco mosaic disease', Stud. Hist. Philos. Sci., 1991, 22: 557-88; included as Chapter 2 of the present study.

11. Ton van Helvoort, 'The construction of bacteriophage as bacterial virus: linking endogenous and exogenous thought styles', J. Hist. Biol., 1993, 26: in press; see Chapter 6 of the present study.

12. Gerald Holton, Thematic origins of scientific thought: Kepler to Einstein (revised edition), Cambridge, Mass., Harvard University Press, 1988.

13. For biographical information on d'Hérelle see Pierre Nicolle, 'Félix d'Hérelle', Presse Méd., 1949, 57: 350; Pierre Lépine, 'Necrologie: Félix d'Hérelle (1873-1949)', Ann. Inst. Pasteur, 1949, 76: 457-60; Jean Théodoridès, 'F. d'Hérelle', in Dictionary of scientific biography, ed. Charles C. Gillispie, 16 vols, New York, Charles Scribner's Sons, 1972, vol. 6, pp. 297-9.

14. See Georges Bertillon, 'Une épidémie de dysenterie hémorragique dans un escadron de dragons', Ann. Inst. Pasteur, 1916, 30: 141-4; Félix d'Hérelle, 'Sur un bacille dysentérique atypique', ibid., pp. 145-7. 
presence of a specific filterable virus could be shown. ${ }^{15}$ D'Hérelle, therefore investigated the possibility that in the case of bacillary dysentery also such an additional factor could play a role. For this purpose he filtered the stools of a dysentery patient through an ultrafilter and combined the filtrate with a culture of dysentery bacilli. To activate the mixture he incubated it overnight, and the following morning to his surprise the container was clear instead of containing the expected turbid culture. D'Hérelle concluded that he had discovered a principle which was antagonistic to dysentery bacilli. Such a principle would explain the absence of bacilli observed in some of his patients. ${ }^{16}$

The first results of d'Hérelle's studies were presented by Emile Roux at the French Académie des Sciences in September 1917.17 D'Hérelle claimed that the antagonistic principle was filterable, living and organized, and hence a microbe. He thought the living nature of the principle proven by the possibility of transmitting it in a series of cultures of dysentery bacilli: a very small amount of the ultrafiltrate in a fresh bacterial culture resulted in the same amount of lytic principle as was present in the original lysate. It was possible to transmit the phenomenon endlessly. Another observation was that when a mixture of bacteria and a highly diluted filtrate of a lysed bacterial culture was cultured on a slant (gélose incliné or sloped agar) small circular patches appeared in the bacterial layer. Because, as d'Hérelle stated, a chemical substance could not concentrate itself at a particular spot, the presence of bacterium-free spots proved the "organized" character of the principle. D'Hérelle called his discovery a microbe which was antagonistic to dysentery bacilli, i.e. an obligatory bacteriophage. ${ }^{18}$

The in vitro antagonistic action of the bacteriophage to a bacillary pathogen immediately suggested that the filterable agent could also play a role in the natural course of bacillary dysentery. In 1918, d'Hérelle concluded that the pathogenicity of dysentery

15. See John M'Fadyean, 'The ultravisible viruses', J. Comp. Path. Ther., 1908, 21: 58-68, 168-75 and 232-42, on pp. 173-5.

16. For this version of the discovery of the bacteriophage phenomenon see Félix d'Hérelle, The bacteriophage and its clinical applications, London, Baillière. Tindall \& Cox, 1930, pp. 1-4.

17. Félix H. d'Hérelle, 'Sur un microbe invisible antagoniste des bacilles dysentériques': Compt. Rend. Acad. Sci., Paris, 1917, 165: 373-5.

18. By using the suffix "phage" d'Hérelle wanted to indicate that bacteriophage multiplied at the expense of the bacterium, not that it "eats" the bacterium (cf. the engulfment of bacteria by phagocytes). See Félix d'Hérelle, The bacteriophage and its behavior, London, Baillière, Tindall \& Cox, 1926, pp. 18-19. 
bacilli in infected humans was indeed dependent on the presence of the microbe filtrant bacteriophage discovered by him. When he subsequently discovered that the bacteriophage was also present in healthy humans he suggested the general name Bactériophagum intestinale 1918 for the agent. The part that the bacteriophage played in the development of bacterial infections was to be used by d'Hérelle and many others in the treatment of these diseases. This became known as bacteriophage therapy. ${ }^{19}$

For some years d'Hérelle was the only one who studied the phenomenon he had described, but this changed when Tamézo Kabéshima entered the field. This Japanese researcher, who worked in d'Hérelle's laboratory, received a bacteriophage sample from him. ${ }^{20}$ The irony was that not only did Kabéshima's conclusion on the nature of the bacteriophage contradict that of d'Hérelle, but it also sparked off intense opposition by influential scientists.

To Kabéshima the properties of d'Hérelle's microbe filtrant bactériophage were not those of an organism but of a ferment. On the basis of this dissenting interpretation, he assumed the following mechanism for the dissolution of a dysentery culture. Kabéshima supposed that a gland in the digestive tract secreted a catalyst which dissolved the pathogenic bacteria. Serial transmissibility of the phenomenon was to be explained by the presence of a prodiastase in the microbes, which, under the influence of the catalyst, was set free as a fresh catalyst in the "autolysis" of the bacterium. According to Kabéshima, his former use of the term microbe de d'Hérelle should be replaced by solution de ferment d'immunité bactériolysant. ${ }^{21}$

Kabéshima based his characterization of a bacteriophage as a ferment on two observations which he saw as absolutely contradictory to the hypothesis which had been formulated by d'Hérelle. After being stored for four years at room temperature (remember that Kabéshima studied bacteriophage in d'Hérelle's laboratory) a filtered Jysate was still capable of bringing about lysis in a fresh bacterial culture. This contra-

19. Félix d'Hérelle, 'Sur le rôle de microbe filtrant bactériophage dans la dysenterie bacillaire', Compt. Rend. Acad. Sci., Paris, 1918, 165: 970-2; idem, 'Technique de la recherche du microbe filtrant bactériophage', Compt. Rend. Soc, Biol, 1918, 81: 1160-2. On bacteriophage therapy see, for instance, William C. Summers, 'On the origins of the science in Arrowsmith: Paul de Kruif, Felix d'Herelle, and Phage', J. Hist. Med., 1991, 46: 315-32.

20. Félix d'Hérelle, The bacteriophage, its role in immunity, Baltimore. Williams \& Wilkins, 1922 , p. 145.

21. Tamézo Kabéshima, 'Sur un ferment d'immunité bactériolysant, du mécanisme d'immunité (des maladies) infectieuse(s) intestinale(s), de la nature du dit "microbe filtrant bactériophage" de d'Hérelle', Compt. Rend. Soc. Biol., 1920, 83: 219-21, on p. 221; the additions in brackets are errata, ibid., p. 264 
dicted the phenomena of degeneration that were shown by living bacteria if they were stored for a long time. Secondly, Kabéshima had observed that the principle remained active after exposure to temperatures of 65 to $70{ }^{\circ} \mathrm{C}$ in a humid environment. It also resisted the action of antiseptic agents like chloroform, toluene, alcohol and ether, while it was known that such chemicals destroyed the vital activity of cells. The principle discovered by d'Hérelle also retained its activity after exposure to 1 per cent sodium fluoride, while it was known that living fermentative processes were immediately stopped by this agent. ${ }^{22}$

D'Hérelle did not wait long before responding to the position taken by Kabéshima. The question was whether the bacteriophage was an organized or a non-organized ferment, i.e. a ferment figuré, d'un microbe parasite des bactéries or a ferment soluble, d'une diastase. ${ }^{23}$ D'Hérelle's and Kabéshima's differing interpretations were to dominate the controversy on the nature of the bacteriophage for several decades to come: the bacteriophage as a living, filterable virus versus the bacteriophage as a ferment or enzyme. The lines along which d'Hérelle was to defend his position will be discussed more fully later on. But first we will see that not only was d'Hérelle's interpretation of the bacteriophage phenomenon to be challenged, but also his claim to have discovered it. In the course of the priority dispute d'Hérelle changed his definition of bacteriophagy.

\subsection{PRIORTTY DISPUTE AND REIFICATION OF BACTERIOPHAGY}

Jules Bordet, also, defended the theory that bacteriophagy was not to be explained as the consequence of a living ultravirus but as the result of the action of a lifeless ferment. This Belgian scientist, who was to become a powerful opponent of d'Hérelle, received his training at the laboratory of Élie Metchnikoff at the Pasteur Institute in Paris at the end of the nineteenth century. Before his thirtieth year he had

22. Tamézo Kabéshima, 'Sur le ferment d'immunité bactériolysant', Compt. Rend. Soc. Biol., 1920, 83: 471-3,

23. Félix d'Hérelle, 'Sur le microbe bactériophage', Compt. Rend. Soc. Biol, 1920, 83: 247 9, on p. 249. The dichotomy between the interpretation of the nature of a filterable virus as a living microbe or germ (organized fement) and as a lifeless ferment endured for more than three decades (see Heinrich Bechhold, 'Ferment oder Lebewesen?', Kolloid-Zeitschr., 1934, 66: 329-40 and idem, 1934, 67: 66-79). Martinus W. Beijerinck's conception of a contagium vivum fluidum for tobacco mosaic virus (TMV) can be regarded as a hybrid between these two classical positions, but not many scientists took his point of view (see Helvoort, op. cit., note 10 above). It is to be noted that Pasteur used the phrase "theory of germs" (théorie des germes) for the first time in 1876; before then he spoke of the "theory of organized ferments". See Carter, op. cit., note 9 above, p. 530, footnote 9. 
done important work in the field of serology and humoral immunity. ${ }^{24}$ In March 1921, Bordet and his fellow worker Mihai Ciuca announced that they had traced a publication by Frederick Twort which contained the real first description of the d'Hérelle phenomenon. Because of the "souci d'un historique exact" they considered it their responsibility to point out the existence of this article dating from 1915. According to Bordet and Ciuca the priority of the English scientist could not be doubted: "Sans vouloir diminuer l'intérêt des constatations de d'Hérelle, nous avons cru que c'était un devoir de reconnaître l'incontestable priorité de Twort dans l'étude de cette question." 25 As is pointed out by Alan Varley, it was not Bordet who first drew attention to Twort's 1915 article, but the author himself. In a paper called 'Researches on dysentery' - which was totally neglected in bacteriophage research - Twort discussed both d'Hérelle's paper of 1917 and his own of 1915. The work of d'Hérelle seemed a confirmation of his own earlier research. ${ }^{26}$

Frederick Twort was superintendent of the Brown Animal Sanatory Institution, which was associated with the University of London. For his study on the nature of filterable viruses Twort had used cheap and widely available raw material, i.e. glycerinated vaccinia pulp. ${ }^{27}$ In an attempt to cultivate vaccinia virus on a lifeless nutrient he observed that colonies of micrococci (staphylococcus), which were present as a contamination in glycerinated vaccinia pulp, underwent a change which he designated as "glassy and transparent". This change could be transmitted with an inoculation

24. For biographical information on Jules Bordet see Paul Bordet, 'L'Institut Pasteur de Bruxelles', Ann. Inst. Pasteur, 1950, 79: 507-20; J. Beumer, 'Jules Bordet 1870-1961', J. Gen. Microbiol., 1962, 29: 1-13; Jean Vieuchange, 'Jules Bordet', in Gillispie, op. cit., note 13 above, 1973, vol. 2, pp. 300-1. See also A. Petterson, 'Presentation speech Nobel Prize physiology or medicine 1919', in Nobel lectures: physiology or medicine 1901-1921, Amsterdam, Elsevier, 1967, pp. 519-22; Anna-Brita Laurell, 'Jules Bordet - A giant in immunology', Scand. J. Immunol., 1990, 32: 429-32. Jules Bordet did not present a Nobel Lecture because of his visit to the United States of America.

25. Jules Bordet and Mibai Ciuca, 'Remarques sur l'historique de recherches, concernant la lyse microbienne transmissible', Compt. Rend. Soc. Biol, 1921, 84: 745-7, on p. 745 and p. 747 respectively. Cf. Félix d'Hérelle, 'Sur l'historique du bactériophage', ibid., 1921, 84: 863-4.

26. Frederick W. Twort, 'Researches on dysentery', Brit. J. exp. Path., 1920, 1: 237-43, on p. 237; discussed in Varley, op. cit., note 7 above, pp. 249-55.

27. Frederick W. Twort, 'An investigation on the nature of ultramicroscopic viruses', Lancet, 1915, ii: 1241-3. Vaccinia pulp is the material which is scraped off from the carved skin after infection with vaccinia virus. Such pulp is a mixture of epidermal cells, leukocytes, plasma, hair, bacteria and vaccinia virus. The larger parts were removed, after which glycerin was added to stabilize the virus and control the multiplication of bacteria. 
needle to colonies of normal micrococci. The active principle could be transmitted in series and was found to be filterable through the finest ultrafilters. Twort had proposed three possibilities for the nature of the principle, though he did not express any preference as to which one would be the most probable. The principle could be an ultramicroscopic virus, a product of the microbe or a stage in the life cycle of the bacterium. The first option represented the position taken by d'Hérelle, while the second, the endogenous origin of the principle, was related to Bordet's position. It seems likely that Jules Bordet used Twort's independent and earlier publication to reaffirm the position that he himself was defending. ${ }^{28}$

Within the scientific community priority is important ${ }^{29}$, and d'Hérelle used two strategies to try and safeguard his priority in discovering the bacteriophage. First, he attempted to antedate his findings. In the English translation of his first monograph on bacteriophagy, d'Hérelle added a new chapter on the nature of the bacteriophage. Here he claimed to have already observed bacteriophagy in his studies of locusts on which he had reported since 1911. These appeared to be resistant to a cocco-bacillus with which d'Hérelle had tried to control a locust pest. ${ }^{30} \mathrm{He}$ ascribed this resistance to an "antagonistic principle", in other words the bacteriophage. However, this reconstruction of his first observation of bacteriophagy aroused suspicions about d'Hérelle's honesty in the question of priority. ${ }^{31}$

As a second line of defence, d'Hérelle stated that bacteriophagy was to be distinguished from other phenomena which showed superficial similarities to bacterio-

28. Cf. Duckworth, op. cit., note 7 above, p. 798.

29. Robert K. Merton, 'Priorities in scientific discovery: a chapter in the sociology of science', Am. soc. Rev., 1957, 22: 635-59; reprinted in Norman W. Storer (ed.), The sociology of science: theoretical and empirical investigations, University of Chicago Press, 1973, pp. 286-324.

30. D'Hérelle, op. cit., note 20 above, p. 144. Cf. Félix d'Hérelle, 'Sur une épizootie de nature bactérienne sévissant sur les sauterelles au Mexique', Compt. Rend. Acad. Sci., Paris, 1911, 152 : 1413-15; idem, 'Le coccobacille des sauterelles', Ann. Inst. Past., 1914, 28: 280-328 and 387-407; idem, 'Sur le procédé bjologique de destruction des sauterelles', Compt. Rend. Acad. Sci., Paris, 1915, 161: 503-5.

31. Cf. Duckworth, op. cit., note 7 above, p. 799. The English edition of 1926 first told the full story of d'Hérelle's observation of the bacteriophage phenomenon in 1910. See d'Hérelle, op. cit., note 18 above, pp. 1-2. According to Macfarlane Burnet the bacteriophage phenomenon was so striking that "in all probability bacteriophage plaques must have been seen occasionally on urine cultures almost from the time when Koch first developed solid jelly-like media for the growth of bacteria." See Sir Macfarlane Burnet, Changing patterns; an atypical autobiography, Melbourne, W. Heinemann, 1968, pp. 53-4. 
phagy. However, studies by E. H. Hankin (1896), the later work of R. Emmerich and O. Low (1901) and that of E. Gildemeister (1917) could have been related to the bacteriophage phenomenon. But none of these scientists had taken the position which d'Hérelle defended so ardently, i.e., that the bacteriophage was a living filterable virus. ${ }^{32}$ The observations reported in 1915 by Twort, who had suggested the possibility of a viral nature, were evaluated by d'Hérelle as not belonging to the bacteriophage phenomenon. He contested the conclusion of André Gratia and D. Jaumin, who claimed that the phenomena of Twort and d'Hérelle were identical. D'Hérelle concluded from their study that staphylococci were indeed susceptible to bacteriophage, but also that they showed a second disease, i.e. the phenomenon described by Twort. This consisted of a "fragmentation" of the bacteria resulting in a residue which could be stained with Giemsa, while bacteriophagy was expressed as a "total dissolution" of the bacteria. D'Hérelle underlined his conclusion on the nature of the Twort phenomenon with the same rhetorical device that he had used in 1917, i.e., the reification of a phenomenon by giving it a name. D'Hérelle described such a fragmentation of cocci as bacterioclysis. ${ }^{33}$

A decade after the rediscovery of Twort's article, feelings on the conflict about the identity of the two phenomena still ran high. Over the years the tension between d'Hérelle and André Gratia had come to a head and the latter was inclined to accord Twort almost total priority: “... Twort avait pratiquement tout vu et tout pensé sur le bactériophage et n'avait oublié qu'une chose: lui donner un nom". ${ }^{44}$ In 1931 d'Hérelle proposed that an arbitral committee decide the question by performing an experiment with Gratia's consent. Paul Flu attended the experiment on behalf of d'Hérelle, while Gratia was represented by Ernest Renaux. The committee concluded that the phenomenon described by Twort could be obtained with staphylococci, resulting in transparent particles which could be coloured with Giemsa red. Because these particles were characterized by their (bacterial) sterility, their multiplication and

32. See d'Hérelle, op. cit., note 18 above, pp. 5-13. According to d'Hérelle neither the work of R. Emmerich and O. Low (1899) on autolysis of B. pyoc)aneus, nor the autolysis of $B$. anthracis which had been studied by Gamaleya (1899) and later by G. Malfitano (1900) were examples of bacteriophagy. The work of Gamaleya is discussed in David Bardell, 'An 1898 report by Gamaleya for a lytic agent specific for Bacillus Anthracis', J. Hist. Med., 1982, 37: 222-5.

33. André Gratia and D. Jaumin, 'Identité du phénomène de Twort et du phénomène de d'Hérelle', Compt Rend. Soc. Biol., 1921, 85: 880-1; 'Bacterioclysis: the Twort phenomenon', in d'Hérelle, op. cit., note 18 above, pp. 13-18, on p. 16.

34. André Gratia, 'Le phénomène de Twort et la bactériophagie; dernière réponse à $M$. d'Herelle', Ann. Inst. Pasteur, 1931, 47: 243-4, on p. 244. 
the serial transmissibility of the phenomenon, it was concluded that the Twort phenomenon did indeed belong to bacteriophagy. In 1938 d'Hérelle admitted that the two phenomena were identical, but he pointed out that the Twort phenomenon was very rare. ${ }^{35}$

The combination of doing experiments and negotiating the question of how to perform and evaluate them produced a consensus about the identity of the Twort and the d'Hérelle phenomena. This established the priority of Twort, a point of view that had already been accepted by many bacteriologists in the early 1920 s. $^{36}$ But it was equally important that in the priority dispute it was decided what was to be regarded as the action of a bacteriophage and what was not. Until the arbitral experiment, d'Hérelle defined it as the total dissolution of a bacterial culture while after the consensus was reached the scope of the phenomenon was widened. Lysis of staphylococci which left bacterial debris also had to be classified as bacteriophagy, because the consensual criteria were sterility and multiplication of the principle and the serial transmissibility of the phenomenon. The point of view that the bacteriophage phenomenon also included other observations apart from the rapid and total dissolution of bacteria, advocated by d'Hérelle as the preferred experimental model, was emphasized in the work of Jules Bordet. ${ }^{37}$

35. Félix d'Hérelle, 'Le phénomène de Twort et la bactériophagie', Ann. Inst. Pasteur, 1931. 47: 470-1; Paul C. Flu and Ernest Renaux, 'Le phénomène de Twort et la bactériophagie', ibid., 1932, 48: 15-18. In 1938 d'Hérelle wrote about the identity that the "phénomène vu par Twort est une manifestation, extrêmement rare, de la bactériophagie." See Félix d'Hérelle, Le phénomène de la guerison dans les maladies infectieuses, Paris, Masson, 1938, p. 15.

36. At the 19th annual meeting of the British Medical Association, held in July 1922 in Glasgow, it was concluded that "it was the almost unanimous opinion of those who took part in the discussion (...) that the Twort and d'Hérelle phenomena are identical. ... though d'Hérelle cannot be given priority in the discovery of the phenomenon, he undoubtedly deserves credit for having awakened a lively interest in the question raised ...". See Anon., 'The discussion on bacteriolysis', Brit. med. J., 1922, ii: $313-14$, on p. 313.

37. In 1939 in a review of bacteriophagy, Friedrich Hoder wrote that bacteria could undergo a broad range of changes under the influence of bacteriophage: “ ... die von mehr oder weniger weitgehenden Veränderungen ihrer äuBeren Gestalt und ihrer Eigenschaften bis zur völligen Vernichtung in Form einer spurlosen Auflösung gehen." See Friedrich Hoder, 'Bakteriophagen', in E. Gildemeister, E. Haagen and O. Waldmann (eds), Handbuch der Viruskrankheiten, Jena, Gustav Fischer, 1939, vol. 2. pp. 686-7I3, on pp. 686-7. 


\subsection{D'HÉRELLE'S INTERPRETATION FURTHER CRITICIZED}

The phenomenon studied by Jules Bordet and Mihai Ciuca, which was linked to that described by d'Hérelle, was presented at the Belgian Société de Biologie on 9 October 1920.38 They had injected guinea pigs three or four times, at intervals of a few days, with a culture of Bacillus coli (later renamed Escherichia coli) in the peritoneum. When peritoneal fluid was subsequently removed with a syringe, this was found to contain many leukocytes. Bordet and Ciuca had then found that when this exudate was mixed with a normal culture of $B$. coli the latter bacteria underwent a change. They got an "autolytic power" which could be transmitted to a fresh bacterial culture. A minute quantity of the lysate was sufficient to bring about this lytic power. The lytic principle was not isolated by filtration, as d'Hérelle had done, but by heating the exudate to 60 to $65^{\circ} \mathrm{C}$, killing the bacteria but leaving the autolytic principle active. In this way, Bordet and Ciuca claimed to have isolated the same phenomenon as that reported by d'Hérelle, which was present as an active principle in a filtrate of stools. Thus, their claim that they had observed the same phenomenon as d'Hérelle's bacteriophagy was not based on performing the same isolation technique but on a partial overlap of the observed phenomena, i.e. the serial transmissible lysis of a bacterial culture. The great difference in experimental design between the studies of d'Hérelle and the experiment of Bordet and Ciuca may prompt the question as to why the latter studied d'Hérelle's phenomenon in this way. Three aspects of d'Herrelle's and Kabéshima's publications could have led to this, aspects which impinged on the study area in which Bordet was a recognized expert, viz. serology or humoral immunity. Therefore, a brief summary of Bordet's serological work around the turn of the century is appropriate. ${ }^{39}$

38. Jules Bordet and Mihai Ciuca, 'Exsudats leucocytaires et autolyse microbienne transmissible', Compt. Rend. Soc. Biol., 1920, 83: 1293-5; idem, 'Le bactériophage de d'Hérelle, sa production et son interprétation', ibid., pp. 1296-8.

39. For a history of immunology see 'Historical sketch of our knowledge on immunity', in Élie Metchnikoff, Immunity in infective diseases, 1905, repr. New York, Johnson Reprint Corporation, 1968, pp. 505-43; 'The scientific basis of immunology', in William D. Foster, A history of medical bacteriology and immunology, London, W. Heinemann, 1970, pp. 92-126; 'Immunology: cellular' and 'Immunology: humoral', in Hubert A. Lechevalier and Morris Solotorovsky, Three centuries of microbiology, New York, Dover, 1974, pp. 182-209 and pp. 21059 respectively: 'History of doctrines of immunity', in William Bulloch, The history of bacteriology, 1938, repr. New York, Dover, 1979, pp. 255-83; Debra J. Bibel, Milestones in immunology: a historical exploration, Madison, Wisconsin, Science Tech Publishers, 1988; Arthur M. Silverstein, A history of immunology, San Diego, Academic Press, 1989; Alfred I. Tauber and 
In the last decade of the nineteenth century an injection of bacteria into the peritoneum of a small laboratory animal was a standard method in immunological research..$^{40}$ In the mid-1890s Bordet used this experimental system to replicate and investigate further an observation that had been described by Richard Pfeiffer in 1894 . Pfeiffer had observed that cholera vibrios underwent a granular transformation in the peritoneal cavity of actively or passively immunized animals. He supposed this to be a "vital" action which would occur only in living animals and thus had to be distinguished from the bactericidal effect shown by cholera serum in vitro. In 1895, Élie Metchnikoff showed that the granular transformation could also be obtained in vitro by mixing the vibrios with cholera serum and adding peritoneal exudate of a normal guinea pig. In the same year Bordet brought this investigation one step further by showing that granular transformation could be obtained in vitro if one used fresh cholera serum or when fresh serum of a non-immunized animal was added to old or heated cholera serum. Bordet concluded from this that the transformation of the cholera vibrio was caused by the action of two substances: one heat-resistant antibody (substance sensibilisatrice), which was found only in immunized animals, and a heatlabile substance (alexine) which was present in both immunized and non-immunized animals.

In 1898 Bordet published his research, in which he claimed that immunization could be used to obtain a hemolytic serum, i.e. a serum which could lyse blood cells of another animal species. Like the serum that transformed bacteria, it was dependent on a heat-resistant specific component and a heat-susceptible non-specific component. Bordet developed this parallel between sera against bacteria and red blood cells into the complement fixation test, in which hemolysis was used as an indicator system for the presence or absence of the non-specific complement. In the presence of bacterium and antibody, complement was exhausted, so no hemolysis could occur, and vice versa. ${ }^{41}$ The parallel between the immunological reactions to bacteria and those to Leon Chernyak, Metchnikoff and the origins of immunology: from metaphor to theory, New York, Oxford University Press, 1991. For the work of Bordet on immunology see also the literature in note 24 above.

40. The peritoneum was also used for the cultivation of microbes which could not be obtained by inoculation into the usual media. See [Edmond I. E.] Nocard, [Emile] Roux, [Amédée] Borrel, [Alessandro T.] Salimbeni and [E.] Dujardin-Beaumetz, 'Le microbe de la péripneumonie', Ann. Inst. Pasteur, 1898, 12: 240-62; reprinted as 'The microbe of pleuropneumonia', Revs Inf. Dis., 1990, 12: 354-8. At present the agent of pleuropneumonia is classified as a mycoplasma.

41. For a discussion of the complement fixation test and the problems of applying it in the Wassermann reaction on syphilis see Bernard Zalc, 'Some comments on Fleck's interpretation of the 
red blood cells from foreign species added to the characterization of the granular transformation as a bacteriolytic process. We can now return to the question of what prompted Bordet to study the d'Hérelle phenomenon.

The initial motivation for Bordet and Ciuca could be that they wanted to investigate the role of leukocytes in the phenomenon, since Kabéshima had suggested that these cells could be the cause of the bacteriolytic phenomenon. As a consequence of the invasion of pathogenic bacilli, cases of dysentery showed many leukocytes in the watery stools. The technique used by Bordet and Ciuca, the intraperitoneal injection of bacteria in a guinea pig, was a standard technique for obtaining an exudate rich in leukocytes. Secondly, the transmissible lysis observed by d'Hérelle could be related to the bacteriolytic and hemolytic phenomena studied by Bordet. ${ }^{42}$ This was also suggested by Kabéshima's remark that bacteriophagy was a form of autolysis perpetuated by the presence of a prodiastase. Another motive that may have contributed to Bordet's taking up the study of the d'Hérelle phenomenon was that d'Hérelle claimed an important role for bacteriophages in the defence against and the convalescence from bacterial infections. The previously mentioned bacteriophage therapy was based on this supposed activity of bacteriophage as an exogenous virus parasitizing on the pathogenic microbe. Therefore d'Hérelle's claim for this important role of bacteriophages meant a direct attack on the importance of the mechanisms of humoral immunity and cellular immunity, which were Bordet's chief claim to fame.

However, Bordet's and Ciuca's investigation also fell within Bordet's expertise in a different way. In addition to the recovery of an autolytic principle from an exudate rich in leukocytes, they observed that a lysed bacterial culture was not totally sterile (in the bacteriological sense of the word). Although the remaining microbes developed only very slowly in broth extract, it was possible to harvest abundantly growing bacterial cultures on agar. In comparison with the original culture of the B. coli strain, such new colonies had totally different characteristics. They were very viscous, shiny, glairy and even liquid. Furthermore, the virulence of this new bacterial variant for the Bordet-Wassermann reaction in view of present biochemical knowledge', in Cohen and Schnelle, op. cit., note 4 above, pp. 399-406.

42. The relation between the phenomena of bacteriolysis and hemolysis on the one hand and Bordet's study of the phenomenon of d'Hérelle on the other is also apparent from the title of one of his "Herter Lectures" at the Johns Hopkins University. In this lecture the leukocytic exudates were, perhaps erroneously, designated in the title as "hemolytic exudates". See Jules Bordet, "Hemolytic exudates and transmissible bacterial autolysis [Lecture III of the Herter Series]', Johns Hopkins Hosp. Bull, 1921, 32: 302-4. 
guinea pig was enhanced and the variant bacteria had the power to lyse a normal bacterial culture. The latter property was designated by Bordet and Ciuca as lysogenic ${ }^{43}$ Bordet discussed the development of the new bacterial forms within the context of what was known as bacterial variation, a field that was familiar to him. Properties of the bacterial variants he had studied were their macroscopic appearances, fermentative properties, virulencies, etc. ${ }^{44}$

According to Bordet, d'Hérelle's phenomenon had to be interpreted within the context of bacterial variation, which he conceived of as an expression of changed bacterial metabolism. This is apparent from his theoretical discussion of these phenomena, which preceded the presentation of the experimental results obtained with the exudate rich in leukocytes. To Bordet and Ciuca, heredity was the transmission of variations, which occurred via two factors, one extracellular and the other intracellular. Each variation depended on a direct factor, which in turn depended on an external one. The intracellular factor had to be transmitted to the progeny, or it would lose its power. If, as Bordet and Ciuca argued, these ideas on microbial variation were applied to transmissible autolysis, then this phenomenon had to be explained as the consequence of a temporary, external cause that induced the microbes to produce a substance which brought about autolysis and which was also transmitted to their descendants. If it was accepted that this substance could diffuse into the medium, then it was clear that the variation was not only hereditary but also contagious. Bordet and Ciuca supposed that the hereditary variation was a disruption of the equilibrium

43. Bordet and Ciuca, op. cit., note 38 above, pp. 1293-8; see also Bordet, op. cit., note 42 above. For Bordet and Ciuca both the slimy microbe and the lysed bacterial culture were lysogenic. One important aspect of the work of Andre Lwoff was that he defined lysogeny as a property of an individual bacterium and not as a property of a bacterial culture. See Lwoff, op. cit., note 7 above, p. 274.

44. See Jules Bordet and [Jan G.] Sleeswijk, 'Sérodiagnostic et variabilité des microbes suivant le milieu de culture', Ann. Inst. Pasteur, 1910, 24: 476-94. For reviews of bacterial variation in the early twentieth century see for instance Felix Löhnis, 'Studies upon the life cycles of the bacteria; Part I: Review of the literature, 1838-1918', Mem. Nat. Acad. Sci., 1922, 16 (2): 1-252; Joseph A. Arkwright, 'Variation', in A system of bacteriology in relation to medicine, Medical Research Council, London, HMSO, 1930, vol. 1, pp. 311-74. The history of bacterial variation before the Luria/Delbrück era of bacterial genetics is discussed by William C. Summers, 'From culture as organism to organism as cell: historical origins of bacterial genetics', J. Hist. Biol., 1991, 24: 17190. See also Olga Amsterdamska, 'Medical and biological constraints: early research on variation in bacteriology', Soc. Stud. Sci., 1987, 17: 657-87; idem, 'Stabilizing instability: the controversy over cyclogenic theories of bacterial variation during the interwar period', J. Hist. Biol, 1991, 24: 191-222. 
between the assimilation of certain substances and their de-assimilation, and they characterized the transmissible autolysis as a "hereditary nutritional corruption" (viciation nutritive héréditaire). ${ }^{45}$

We have seen that d'Hérelle explained the bacteriophage phenomenon as the result of an exogenous ultravirus which could be isolated from the digestive tract of both patients and normal persons. Bordet interpreted his findings on the basis of his knowledge of lytic processes and of bacterial variation, which he thought to be an expression of the metabolism or physiological state of the bacteria. This represents a dichotomy between an exogenous cause of the bacteriophage phenomenon and an endogenous explanation. This dichotomy can also be found in later controversies on the bacteriophage and in the development of research on plant viruses. As the years passed, d'Hérelle and Bordet would each develop their own experimental system and theory further, thus creating their own research styles.

\subsection{FÉLIX D'HÉRELLE AND THE BACTERIOPHAGE: A BACTERIOLOGICAL STYLE}

In 1921 d'Hérelle's first book on bacteriophagy appeared as a monograph of the Parisian Pasteur Institute, followed a year later by a revised English translation. In 1926 he published his magnum opus, in both a French and an English edition. ${ }^{46}$ According to d'Hérelle, bacteriophagy was a two-part phenomenon, namely the dissolution of the bacteria and the multiplication of bacteriophages. Bacteriophagy was an infectious disease of the bacterium and because the etiological agent, the bacteriophage, passed through an ultrafilter, it had to be regarded as an ultravirus. In this respect d'Hérelle remained a faithful adherent of the Pasteurian point of view that infectious diseases were caused by living organisms. After all, Louis Pasteur had written: "En résumé, 'tout virus est un microbe'."47 However, if d'Hérelle had

45. Bordet and Ciuca, op. cit., note 38 above, pp. 1293-5. The presentation of a theoretical discussion before reporting the experimental results makes the conclusions seem more "inevitable".

46. Félix d'Hérelle, Le bactériophage; son rôle dans l'immunité, Paris, Masson, 1921 ; idem, op. cit., note 20 above; idem, Le bactériophage et son comportement. Paris, Masson, 1926; idem, op. cit, note 18 above. For the summary of d'Herelle's ideas about bacteriophage and bacteriophagy 1 have mostly used the English edition of the latter book.

47. Pasteur Vallery-Radot, Oeuvres de Pasteur, vol. 6, Maladies virulentes, virus-vaccins et prophylaxie de la rage, Paris, Masson, 1933, p. 673; cited in Galperin, op. cit., note 7 above, p. 179. Pasteur here used the term "virus" to mean all infective agents, that is, bacteria, but also those agents which had not yet been isolated and cultivated (e.g. the agent of rabies). For a discussion of 
adhered strictly to the Pasteurian point of view he would have had to maintain that the bacteriophage was an ultramicrobe, which was indeed his first conviction. Later on he claimed that the bacteriophage was alive but had to be characterized as a colloidal particle. However, he borrowed more from his illustrious predecessor than the living nature of an (ultra)virus.

The bacteriological work of Pasteur is characterized by his emphasis on infectious, autonomous microbial entities. Furthermore, Pasteur maintained that microbes are characterized by their adaptation to changing environments, resulting in "microbial variation". To Pasteur, one consequence of the variability of microbes was that the qualitative properties of these agents were of prime importance. ${ }^{48}$ Working within the Pasteurian tradition of viewing microbes as autonomous living agents, these basic assumptions made in the following methodological requirements, necessary for d'Hérelle.

First, he concluded that the quantitative properties of bacteriophagy had to be explained as the results of the multiplication of a living ultravirus, the bacteriophage. As discussed above, the quantitative properties of bacteriophagy could be shown in a liquid by the serial transmissibility of the bacteriophage. ${ }^{49}$ On a solid medium the multiplication of bacteriophages was visible as plaques or blank spots (taches vierges), without bacteria, in a bacterial layer. These were caused by the lysis of bacteria which had originally grown there. D'Hérelle compared such plaques with bacterial colonies on a solid medium, and the bacteriophages could be quantified by counting the number of plaques caused by a known quantity of bacteriophage suspension. ${ }^{50}$ In liquid media, bacteriophage could be quantified by a method the work of Louis Pasteur see for instance René Dubos, Louis Pasteur, free lance of science, 1960, repr. New York, Da Capo Press, 1986; Gerald L. Geison, 'Louis Pasteur', in Gillispie, op. cit., note 13 above, 1974, vol. 10, pp. 350-416; 'Pasteur', in Lechevalier and Solotorovsky, op. cit., note 39 above, pp. 15-62. Roll-Hansen characterized the work of Pasteur on fermentation as a typical example of the physical holism with which Pasteur "defeated reductionist doctrines of spontaneous generation (namely that under appropriate conditions life will arise spontaneously from non-living matter) and the reductionist chemical theories of fermentation." See Nils Roll-Hansen, "Louis Pasteur - A case against reductionist historiography', Brit. J. Philos. Sci., 1972, 23: 347-61, on p. 356.

48. For the importance of the phenomenon of microbial variability in the work of Louis Pasteur see 'Pasteur's work on attenuation of virus', in Bulloch, op. cit., note 39 above, pp. 241-52. For a discussion of "pleomorphism", a former synonym for bacterial variation, see also note 59 below.

49. See 'Bacteriophagy in a fluid medium', in d'Hérelle, op. cit., note 18 above, pp. 37-75.

50. See 'Bacteriophagy upon solid media', in ibid., pp. 76-81. The culturing of bacteria on solid 
developed by Pierre Miquel, which was known as the "dilution method". According to d'Hérelle both methods of culturing were useful for making the multiplication of bacteriophages visible and for quantifying it. Comparison of the two methods of counting the corpuscles showed similar results. ${ }^{51}$ The plaques were evidence of the discontinuity, the particle-like character of the bacteriophage. ${ }^{52}$

According to d'Hérelle the qualitative characteristics of bacteriophagy were more important than the quantitative aspects discussed above, and he pointed to his great leader: "We have known since the days of Pasteur that in a bacterial culture each of the organisms presents individual characteristics, chiefly in those attributes dealing with its virulence". 53 Since d'Hérelle regarded the bacteriophage as a living virus with individual properties and capable of adaptation, it is not surprising that he demanded special attention in the study of the bacteriophage for the qualitative properties of the process of bacteriophagy:

... quantity is a negligible factor, the quality of the bacteriophage is the most important feature of the phenomenon. The only influence exerted by the quantity of the bacteriophage principle inoculated is in the time required for the completion of the phenomenon. ${ }^{54}$.Italics in the original.]

D'Hérelle held the opinion that it was impossible to determine the physicochemical properties which gave matter its living nature. But, as he argued, we do know the result of "life", that is the power to assimilate in a heterologous medium and the power to adapt. ${ }^{55}$ In a microscopic entity, assimilation could not be observed directly; only culture media had been introduced by Robert Koch; cf. Arthur P. Hitchens and Morris C. Leikind, 'The introduction of agar-agar into bacteriology', J. Bact., 1939, 37: 485-93.

51. D'Hérelie, op. cit., note 18 above, pp. 96-9.

52. Ibid., pp. 82-6. The non-molecular notion of a liquid was ridiculed in, for instance, Max Delbrück, 'Bacterial viruses or bacteriophages', Biol. Revs, 1946, 21: 30-40, on p. 38. Cf. Frederick C. Bawden, Plant viruses and virus diseases, 4th ed., New York, Ronald Press, 1964, p. 5.

53. D'Hérelle, op. cit, note 18 above, note on p. 118.

54. Ibid., p. 57.

55. Ibid., pp. 330-2. D'Hérelle first presented this argument in the way that it is discussed here in Félix d'Hérelle, 'Le bactériophage', Rev. Path. Comp. d'Hyg. Gén., 1923, 23: 1-26. Thus d'Hérelle agreed with Claude Bernard who, in his Leçons sur les phénomènes de la vie communs aux animaux et aux végetaux (Paris, Baillière, 1878), had argued that life could only be characterized. Characteristic properties of life were, according to Bernard, organization, generation, feeding, development and susceptibility to disease and death. See Robert P. Cook and Milda A. Cook, Claude Bernard: phenomena of life common to animals and to vegetables, Dundee, Scotland, privately 
the effect of assimilation could be studied, i.e. the multiplication of the organism. ${ }^{56}$ But mere multiplication was not sufficient, because when a particle had reached a certain size, further growth would always lead to a division into two parts. But as this was just a physical process, d'Hérelle argued, this would not imply life. The real criterion for life was the power to assimilate in a heterologous medium. The heterologous character of the bacteriophage, its autonomy, relative to the bacterium on which it multiplied, had in d'Hérelle's opinion been proved by many experiments. ${ }^{57}$ The second property which would characterize "life" was the phenomenon of adaptation, a property of bacteriophage which was proved, according to d'Hérelle, by its variability. ${ }^{58} \mathrm{D}$ 'Hérelle thought that there was only one bacteriophage, which could adapt itself and become virulent to a new bacterial species for which at first it had no virulence. 59

D'Hérelle endorsed Pasteur's point of view that infectious diseases were caused by living organisms, but at the same time he made an adjustment. On the basis of research on the nature of the bacteriophage he concluded that it was a colloid, either of lipoid nature or of protein nature. Consequently, the phenomena of life were not limited to microbes and cellular entities, a view which was not, however, an original thought at this time. 60

printed, 1974. pp. 11-18.

56. According to d'Hérelle the problem of quantifying bacteriophage (and the ultraviruses in general) was that it was difficult to determine whether the agent was alive or dead. After all, the bacteriophage was known through its effect, so that there was no difference between a dead bacteriophage and one which had lost its virulence. See d'Hérelle, op. cit., note 18 above, pp. 283-4.

57. Ibid., pp. 333-41.

58. Ibid., pp. 350-4.

59. Ibid., pp. 366-9. The idea that there might be only one bacteriophage, which could adapt to new hosts, was named by d'Herrelle the "unicity" of bacteriophage. This is reminiscent of the pleomorphism of bacteria which was defended in the nineteenth century by botanists, for instance Carl von Nägeli but also Max von Pettenkofer. An extreme form of pleomorphism was expressed as: "... cocci could become bacilli, and bacilli, spirilla, as the chance of varying environment might dictate." Cited in L. J. Cole and W. H. Wright, "Application of the pure-line concept to bacteria', J. infect. Dis., 1916, 19:209-21, on p. 209. In the last decades of the nineteenth century the concept of pleomorphism was commonly accepted especially in France, inspired by the successes of Pasteur in the attenuation of the virulence of anthrax bacilli and the virus of rabies. Cf. Amsterdamska, 1987, op. cit., note 44 above, p. 669.

60. See 'The physical state of the bacteriophage', in d'Herelle, op. cit, note 18 above, pp. 273 83. D'Hérelle was not original in his claim that there could be non-cellular life. See for instance Felix Löhnis's concept of "symplasm" in Löhnis, op. cit., note 44 above, pp. 166-96. Cited in 


\subsection{FOLLOWING IN LOUIS PASTEUR'S FOOTSTEPS}

As is apparent from the outline of d'Hérelle's position given above, he was a scientist who elaborated his hypotheses into complete theories. He felt that ideologically he was following in the footsteps of the great Louis Pasteur. Just like his predecessor, he did not eschew confrontations with more or less famous adherents of opposing theories. It is especially clear from his defence of the Germ theory of infectious disease that he wished to take over the torch of Pasteur.61 The corollary of the confirmation of this theory was Pasteur's rejection of the idea of "spontaneous generation" of microbial life. ${ }^{62}$

Since d'Hérelle was convinced that bacteriophagy was an infectious disease of bacteria, he saw the opposition to his point of view as the resurrection of the old moot point about whether infectious disease is caused by microbes or is of endogenous origin. After all, his opponents explained the d'Hérelle phenomenon as the result of an endogenous lifeless ferment. As the discussion on the nature of infectious disease cropped up again, d'Hérelle even questioned the insight of his predecessor: "It is indeed certain that Pasteur had too little vision to think that the day would come when the living nature of the ultraviruses would be questioned ...". He felt that it would be necessary to go over the same ground in order to prove once more that the "law announced by the clear genius of Claude Bernard, by Pasteur, and by Koch, is always true, that "all disease reproducing in series arises from a living germ capable of multiplying in the body". 63 D'Hérelle would, incidentally, not have been sorry to find himself among these famous biologists of the nineteenth century.

D'Hérelle stated that these "dead theories must be killed anew" and claimed that the endogenous interpretation of bacteriophagy advanced by Jules Bordet meant the rebirth of the old endogenous theory of Georg Stahl, which had been mobilized against Pasteur by Justus von Liebig. ${ }^{64}$ Liebig's position is illustrated in the Amsterdarnska, 1991, op. cit., note 44 above, p. 201.

61. For the history of bacteriology see, for instance, Bulloch, op. cit, note 39 above and the literature cited in footnote 12 of Chapter 1 of the present study. For a discussion of the Germ theory in the nineteenth century see also Carter, op. cit., note 9 above.

62. On the controversy on "spontaneous generation" see, for instance, John Farley and Gerald $\mathrm{L}$. Geison, 'Science, politics and spontaneous generation in nineteenth-century France: the PasteurPouchet debate', Bull. Hist. Med., 1974, 48:161-98. For a criticism on this version of the controversy see Nils Roll-Hansen. 'The death of spontaneous generation and the birth of the gene: two case studies of relativism', Soc. Stud. Sci, 1983, 13: 481-519.

63. Félix d'Hérelle, Immunity in natural infectious disease, Baltimore, Willians \& Wilkins, 1924, p. 337 and p. 339 respectively. 
following statement, quoted by Louis Pasteur in 1860:

Brewers' yeast, and, in general, all animal and vegetable matter in putrefaction, carry over to other bodies the state of decomposition in which they are themselves. The motion which, due to a loss of equilibrium, affects their own components, is communicated also to the elements of substances which are in contace with them. 65

Because d'Hérelle regarded the bacteriophage as living he could not accept that it could arise spontaneously as was concluded by some on the basis of the phenomenon of lysogeny. For d'Hérelle's opponents lysogeny, the "spontaneous generation" of bacteriophage, was indeed an important argument for the endogenous origin but, at the same time, an argument against the living nature of the bacteriophage (vide infra).

Although d'Hérelle defended the Germ theory of infectious disease by all possible means, he argued that another dictum from biology was ready to be discarded. He thought that he had shown that the bacteriophage was living, belonged to the ultraviruses and could be characterized as a colloidal particle. Therefore the "Cellular theory of life" would have to be replaced by the "Micellar theory of life". D'Hérelle stated that the assertion that the cell was the smallest entity of life had become untenable: "The old adage, all cells are derived from a like cell, should be replaced by all living micellae are derived from the division into two identical parts of an antecedent micella". ${ }^{66}$

For Félix d'Hérelle the consequences of the discovery of the bacteriophage were very far-reaching, because of its role in the course of bacterial infectious diseases. Once again, he was following in the footsteps of Pasteur, who had also emphasized

64. Ibid., p. 339 and p. 262 respectively.

65. Cited in Lechevalier and Solotorovsky, op. cit., note 39 above, p. 22.

66. D'Hérelle, op. cit., note 63 above, p. 52. Cf. Thomas S. Hall, History of general physiology, 600 B.C. to A.D. 1900, vol. 2, From the enlightenment to the end of the nineteenth century, University of Chicago Press, 1969, pp. 307-64. According to d'Hérelle the "Cellular theory of life" was adhered to as a dogma, even though it lacked an explanation for the absence of a nucleus in bacteria: "Always under the obsession of the preconceived idea that a living being must necessarily be cellular, that is, constituted of a differentiated protoplasm, many scientists have sought desperately for this nucleus [of bacteria]. [Fritz] Schaudinn was unable to find it, and, despite his remark that the nucleus can only be defined morphologically, had advanced the hypothesis of the existence of a 'diffuse nucleus'." See d'Hérelle, op. cit, note 63 above, p. 345. Cf. 'Der Zellkern', in Arthur Meyer, Die Zelle der Bakterien, Jena, Verlag von Gustav Fischer, 1912, pp. 40-74; Thomas D. Brock, 'The bacterial nucleus: a history'. Microbiol. Revs, 1988, 52: 397-411. 
the prophylactic and therapeutic applications of his research. ${ }^{67}$ Pasteur had argued that infectious diseases were caused by specific micro-organisms and that attenuation of virulent strains could result in a vaccine to be used to arouse immunity. In this way he had developed vaccines against chicken cholera, anthrax and rabies. Analogous to these uses of the new science of bacteriology, d'Hérelle advanced the use of the newly discovered agent in bacteriophage therapy.

But the discovery of the bacteriophage also had reverberations in the traditional biological and medical sciences: "Suddenly bacteriophagy made its appearance. The structure could not support the added weight of the new facts: it crumbled" 68 Pathology, hygiene, epidemiology and immunology were the medical disciplines that were to be transformed through the discovery of the bacteriophage. When man or animals were infected by a pathogenic microbe, the course of this infection depended on the battle between the infected macro-organism, the bacterium and the bacteriophage. In d'Hérelle's view, the variability of living organisms and of the defensive reactions of the macro-organism meant that there were no strictly defined infectious diseases but only complexes of symptoms. He therefore agreed with a statement by René Laënnec who, he claims, had said that "we do not have diseases, we have only patients". ${ }^{69}$ But besides pathology, other disciplines like epidemiology and hygiene were also to be transformed by the recognition of the role of the bacteriophage. After all, if the bacteriophage was involved in the convalescence from bacterial infectious disease, it could also be used to control it. The living nature of bacteriophage meant that recovery from bacterial disease was also contagious. From this d'Hérelle drew several conclusions about the measures that had to be taken in an epidemic. One example may suffice here to illustrate the impact d'Hérelle attributed to the bacteriophage in hygienic measures. He argued that in an epidemic one normally boiled drinking water to disinfect it, but that this also destroyed the health-bringing bacteriophage. Therefore he advocated filtering drinking water through an ultrafilter in order to

67. See for instance 'War and peace of microbes', in Bruno Latour, The pasteurization of France, Cambridge, Mass., Harvard University Press, 1988, pp. 1-150. For the work of Pasteur see also the literature of note 47 above.

68. D'Hérelle, op. cit, note 16 above, p. vi.

69. Ibid., p. 107. Cf. Jacalyn M. Duffin, 'The medical philosophy of R. T. H. Laennec (17811826)', Hist. Philos. Life Sci, 1986, 8: 195-219; Knud Faber, Nosography: the evolution of clinical medicine in modern times, 2nd ed., 1930, repr. New York, AMS Press, 1978. The existence of an ontological disease entity is an implicit presupposition of "Koch's Postulates" as they are used in proving the etiological relationship between an etiological agent and a disease. See also note 9 above. 
let the bacteriophage do its work in the patient. ${ }^{70}$

In conclusion, it will be clear that d'Hérelle studied the bacteriophage as a living and autonomous infectious entity, with special emphasis on its qualitative properties. Starting from a characterization of the bacteriophage as a filterable microbe, he changed this conception to one of colloidal nature. Despite this change, the living aspects of bacteriophage, i.e. the properties of assimilation and adaptation, were central in his work. It may be concluded that d'Hérelle's work belonged to a bacteriological research style. In its presuppositions on the nature of the bacteriophage, as well as in the way it was studied and in the way this knowledge was put to practical use, d'Hérelle's research belonged to the Pasteurian tradition. The competing notion, which will be more fully discussed in the following sections, explained the phenomenon described by d'Hérelle as the result of an endogenous process of the bacterium, linked with its metabolism and the generation of bacterial variants.

\subsection{JULS BORDET, TRANSMISSIBLE BACTERIAL LYSIS AND IMMUNITY}

At the beginning of their work, Bordet and Ciuca attributed the cause of the phenomenon of transmissible bacterial lysis to the leukocytes. These would secrete a ferment which caused a disruption of bacterial metabolism: "... perhaps the lytic phenomenon observed was merely the consequence of some immunological process, or, so to speak more precisely, was the result of a special modifying influence exerted by the leucocytes on the micro-organisms". In the experimental model of Bordet and Ciuca, a leukocytic exudate was obtained by an injection of bacteria into the peritoneum, while in the case of dysentery, the situation in which d'Hérelle had first observed the bacteriophage, leukocytes were present in the stools. ${ }^{71}$

It has already been pointed out that Bordet's investigations of the d'Hérelle phenomenon were closely related to his expertise in the field of lytic phenomena within the context of serology and immunity. These lytic phenomena were in turn related to processes of digestion by the host and of microbial metabolism. The connection between immunity and digestion already played a role in the work of Bordet's mentor, Élie Metchnikoff. ${ }^{72}$

70. See 'Exogenous immunity: bacteriophagy in vivo', in d'Hérelle, op. cit., note 63 above, pp. 271-307, on p. 307.

71. Jules Bordet, 'Cameron Prize Lecture on microbic transmissible autolysis', Brit. med. J., 1923, i: 175-8, on p. 176. Cf. Bordet and Ciuca, op. cit., note 38 above, pp. 1296-8.

72. For literature on the history of immunology see note 39 above. Cf. 'A digression on immunology', in Varley, op. cit., note 7 above, pp. 98-107. 
It may seem from the historiography of immunology that at the end of the nineteenth century there were two opposing notions of the mechanisms of immunity. On the one hand there was the humoral theory, which explained immunity as the result of bactericidal and antitoxic substances in body fluids; on the other hand there was the notion of immunity as a result of the activity of cells, i.e. the phagocytes. Metchnikoff became known for his studies on the role of phagocytes in the protection against infectious diseases, for which he received the Nobel Prize for Medicine in 1908. ${ }^{73}$ Although Metchnikoff had outlined his ideas in the absence of knowledge of the humoral aspects of immunity, the later French "cellular school" did pay attention to humoral factors. This is evident from the very fact that Bordet did his early, epochmaking research on serology in Metchnikoff's laboratory.

In Metchnikoff's Immunity in infective disease we see that a supposed antagonism between humoral and cellular mechanisms of immunity does not do justice to his ideas on immunity. According to Metchnikoff, the phenomena of humoral immunity had to be explained in relation to those of cellular activity: both were expressions of digestive processes, one extracellular (in the body fluids), the other intracellular (in the phagocyte). ${ }^{74}$ Metchnikoff claimed that two large categories of mobile phagocytes or leukocytes, i.e. microphages and macrophages, each had their own soluble ferment. Metchnikoff named these ferments cytases, classified them as trypsins and regarded them as identical to the alexins or complements of other authors. As long as the phagocytes remained intact, the soluble ferments were not released. However, when the phagocytes were damaged, part of the cytases escaped, a process which he named phagolysis. As a result of this, the serum acquired hemolytic and bactericidal properties. In addition to the cytases, soluble ferments which were in essence intracellular, there were also the fixatives, Ehrlich's amboceptors or intermediary substances, which were humoral. ${ }^{75}$

The mechanism of immunity proposed by Metchnikoff consisted of both chemical and biological processes. The digestion of microbial invaders of the macro-organism

73. See Élie Metchnikoff, 'On the present state of the question of immunity in infectious diseases [Nobel lecture, 1908]', in Nobel lectures, op. cit., note 24 above, pp. 281-300; reprinted in Scand. J. Immunol., 1989, 30: 383-98. It is to be noted that it has recently been argued that Metchnikoff did not conceive phagocytes as "gendarmes" of the organism but as an "independent center of activity, representing in that function its own evolutionary origin". See Alfred I. Tauber, 'The immunological self: a centenary perspective', Perspect. Biol. Med., 1991, 35: 74-86, on p. 77. See also Tauber and Chernyak, op. cit., note 39 above.

74. See 'Summary', in Metchnikoff, op. cit., note 39 above, pp. 544-69.

75. Ibid., p. 80 and pp. 549-57. 
took place within the phagocytes under the influence of chemical and physicochemical processes. But before these processes could come into play the phagocytes showed typically biological phenomena such as the perception of "chemiotactic sensations", migration to endangered tissues, ingestion of bacteria and secretion of substances which took care of intracellular digestion. Immunity in infectious diseases could be regarded as a "section of cellular physiology, and especially as a phenomenon concerned in the absorption of micro-organisms. This absorption being carried out by an act of intracellular digestion, the study of immunity comes into the chapter on digestion regarded from the general point of view". ${ }^{76}$ [Italics mine.]

To Jules Bordet the substances in serum and antiserum which took care of humoral immunity constituted a subject which deserved further study, regardless of their origin. But it could not be doubted that the substances which were responsible for this "chemical" type of immunity were related to the digestive processes of cellular immunity:

The tendency in the study of immunity has been to harmonize these humoral manifestations with the functions of the phagocytes, which, as Metchnikoff has shown, are both in origin and function the digestive cells, fitted to form substances that digest and destroy alien cells. ${ }^{77}$

Bordet interpreted the early results of his study of transmissible bacterial lysis within this context of the "chapter on digestion", more specifically the phenomena of bacteriolysis and hemolysis that were being studied within the science of immunity. Furthermore, transmissible bacterial lysis was definitely related to that of autolysis. Both cells and bacteria were known to undergo a process of degeneration after some

76. Ibid., pp. 566-7. Tauber and Chernyak have argued that Metchnikoff's theory of immunity resided on the fundamental notion of the organism as intrinsically disharmonious and striving for harmony. Immunity and pathological inflammation were conceived as based upon "physiological inflammation, mediated by the phagocyte, which was responsible for 'harmonizing' potentially discordant cellular elements". See Tauber, op. cit., note 73 above, p. 76. Cf. 'Preface' in Tauber and Chernyak, op. cit., note 39 above, pp. xiii-xviii.

77. Jules Bordet, 'Les sérums hémolytiques, leurs antitoxines et les théories des sérums cytolytiques', Ann. Inst. Pasteur, 1900, 14: 257-96; reprinted as 'Hemolytic sera and their antitoxins, and theories concerning cytolytic sera in general', in Studies in immunity by Professor Jules Bordet and his collaborators, collected and translated by Frederick P. Gay, New York, J. Wiley \& Sons, 1909, pp. 186-216, on p. 206. Bordet reiterated Metchnikoff's conclusion that immunity is "simply an instance of intracellular digestion and entirely a chance and efficient application to animal defense of a primitive function which would exist even if there were no pathogenic organisms in existence." See Gay, ibid., p. 141. 
time which was called autolysis, autophagy or autofermentation. In 1913 Maurice Nicolle wrote in a review of autolysis that life was embedded in assimilation and degradation:

... la cellule possède une grande intensité vitale, elle assimile avec énergie et désassimile pareillement. Si l'on vient à supprimer, soudain, l'apport des aliments, on provoque une violente rupture d'équilibre dans le sens de la désassimilation. ... Il en résulte une tendance obligée vers le ramollissement des parties, le flou des images microscopiques, la simplification des constituants moléculaires, c'est-à-dire vers l'autolyse ... ${ }^{78}$ [Italics in the original.]

With regard to the processes of hemolysis and bacteriolysis Nicolle wrote that fundamental changes could be observed in albuminous globulins, the environment and lipids. He thought autolysis to be characterized by softening, decoagulation and molecular collapse (l'écroulernent moléculaire). ${ }^{79}$ Autolysis was a well-known phenomenon in bacteria, which was visible in an extreme form in pneumococci. These bacteria underwent a remarkable form of autolysis in which all the cells plasmolyzed after 24 to 48 hours and the culture became clear. ${ }^{80}$

There are two reasons for discussing here the background of Bordet's work on immunity. First, as stated above, this work formed the context of his interpretation of bacteriophagy. Second, Félix d'Hérelle's criticism was not only directed against the position Bordet took in the bacteriophage controversy but also against humoral serology in general. D'Hérelle made a distinction between experiments performed by chemists and physicists, and those undertaken by biologists. Because of the enduring adaptation of organisms to their environment, experiments by biologists had to be divided into the natural and the artificial. According to d'Hérelle, the experiments of humoral immunology were artificial because they were performed with animals which were naturally resistant to the infections studied. D'Hérelle therefore studied bacteriophage in circumstances he considered natural. He claimed to study natural

78. Maurice Nicolle, 'L'autolyse (Étude de biologie générale)', Ann. Inst. Pasteur, 1913, 27 : 97-1.17, on pp. 102-3.

79. Ibid., pp. 113-15.

80. Joseph M. Dougherty and Anthony J. Lamberti, A textbook of bacteriology and immunology, St. Louis, C. V. Mosby Company, 1946, p. 180. To d'Hérelle, the phenomena of degenerating bacterial cultures were of a fundamentally different nature to bacteriophagy. One important argument was that bacteriophagy was found in young and active bacteria, while autolysis was a phenomenon belonging to old and degenerating cultures. See d'Hérelle, op. cit., note 18 above, pp. 56 and pp. 316-7. 
infectious diseases. ${ }^{81}$ As an example of the artificial character of humoral immunology, d'Hérelle mentioned the bactericidal effect of rabbit blood on anthrax bacilli, while the rabbit was found to be susceptible to anthrax in nature. A counter-example was the insusceptibility to anthrax of the dog, while dog serum showed no bactericidal action. $^{82}$

With this criticism on traditional humoral immunity, d'Hérelle created a niche for the bacteriophage in the recovery from bacterial infectious diseases. He summarized humoral and cellular mechanisms of immunity as endogenous, while the protection by the bacteriophage was characterized as exogenous. ${ }^{83}$ But the artificial character of humoral immunology was not all that was criticized; the nature of the "bacteriolysis" described by Pfeiffer, Metchnikoff and Bordet was also scrutinized by d'Hérelle:

If there is a history which presents a philosophical significance from the point of view of that which may be called "the history of an error" it is indeed the history of the "antibodies." ... The sensitizer became a "lysin;" the simple fixation of complement to a bacterium, in which nothing further is involved, became "bacteriolysis," and the serum containing the sensitizer must be a "bacteriolytic" serum. The magic of words. No one had ever observed the bacteriolysis of a single bacterium under the influence of a serum, but nevertheless, since then many impassioned controversies have been waged to explain the mechanism of this non-existant phenomenon. ${ }^{84}$

81. Félix d'Hérelle argued that chemists and physicists would always perform "natural" experiments but the "biologist selects the conditions of his experiment. He can perform an artificial experiment if the conditions which he elects are artificial, or he can conduct a true experiment if he carries it out under natural conditions. The first leads to error, the second to truth." In d'Hérelle, op. cit., note 63 above, p. 9.

82. Ibid., p. 230. However, this difference between the activity of humoral factors in vitro and the susceptibility of an animal in vivo was recognized by immunologists. According to Metchnikoff the absence of a parallel between natural immunity and the bactericidal power of a serum had to be sought in the complexity of the process by which the cytases were set free from the leukocytes, as well as in the changes they underwent when they were distributed in the body fluids. Furthermore, immunity consisted not only of the chemical processes but also of biological components like the chemotaxis of the phagocytes and the ingestion of pathogenic micro-organisms. See Metchnikoff, op. cit., note 39 above, pp. 553-4. For the reception of the idea of natural antibodies by Pfeiffer, Metchnikoff, Bordet, Ehrlich and Landsteiner see Peter Keating and Abdelkérim Ousman, 'The problem of natural antibodies, 1894-1905', J. Hist. Biol., 1991, 24: 245-63.

83. See 'Natural endogenous immunity: the phagocytic reaction', 'Endogenous acquired immunity: the antitoxic reaction', 'Exogenous immunity: bacteriophagy in vitro' and 'Exogenous immunity: bacteriophagy in vivo', in d'Hérelle, op. cit., note 63 above, pp. 212-25, 226-45, 246-70 and 271-307, respectively.

84. Ibid., pp. 162-3. See also 'The reactions against colloids: the artificial phenomenon of 
D'Hérelle stated that the acceptance of "bacteriolysis" as the very basis of immunity had held back immunology for more than twenty years. It will be obvious that he reserved real lysis of bacteria, without any bacterial debris, for the bacteriophage he had discovered.

\subsection{JULES BORDET AND THE BACTERIOPHAGE: A PHYSIOLOGICAL STYLE}

In the 1920 s Bordet changed his ideas on the cause of the phenomenon of transmissible bacterial lysis twice. These modifications, however, only strengthened his view that the phenomenon belonged to the physiological functions of the bacterium. One important reason for his change of mind was the work of M. Lisbonne and L. Carrère. These scientists had observed that when coli or proteus bacteria were brought into contact with Shiga bacilli, the latter would lyse and produce a bacteriophage. Lisbonne and Carrère concluded from this that certain Shiga bacilli could be used as an indicator strain to show lysogenic properties of coli and proteus bacteria. In 1923 Jules Bordet stated that transmissible bacterial lysis had to be explained from a bacterial antagonism, which meant that the necessity of leukocytes had to be abandoned. 85

Not much later, Bordet once more changed his view. In 1924 he claimed that it was not necessary to have an antagonistic interaction between different species of bacteria. After he had cultured four pure strains of $B$. coli for eight months, three of them appeared to produce principles which could lyse dysentery bacilli of the Shiga type. Because these coli bacteria had had no contact with the dysentery bacilli an antagonism between different species could be excluded as the cause. The explanation he now proposed was based on the phenomenon of bacterial variation. As different fixation", in ibid., pp. 121-40. There seems indeed to be a difference between the "granular transformation" of Pfeiffer's phenomenon and the complete lysis of a bacterial culture as a consequence of d'Hérelle's phenomenon. When Bordet discussed the destructive effect of a cytolytic serum on the attacked cell he stated that the lesion varied with the cell involved: "... the bactericidal action of a fluid or serum on the cholera vibrio is evidenced both in vivo and in vitro by a granular transformation of the organism. The analogous action of hemolytic sera is detectable in vitro as well as intraperitoneally by a destruction of the corpuscles with a diffusion of hemoglobin." [Italics mine.] See Gay, op. cit., note 77 above, pp. 207-8.

85. M. Lisbonne and L. Carrère, 'Antagonisme microbien et lyse transmissible du bacille de Shiga'. Compt. Rend. Soc. Biol., 1922, 86: 569-70; Jules Bordet, 'La théorie de l'antagonisme microbien dans la genèse de la lyse transmissible', ibid., 1923, 88: 1211-13. Cf. Flu, op. cit., note 7 above, p, 122. 
variants came into existence, these interacted with each other and in this way influenced the "evolution" of the culture. ${ }^{86}$

The organized, corpuscular nature of the lytic principle was also contradicted by the observation that the number of plaques on a solid medium depended on the quantity of susceptible microbes. If many bacteria were added to a lytic principle the latter seemed to disappear, while incubation with few bacteria resulted, after a period of time, in a lysed and clear solution: "The very slight amount of lytic agent will indeed be distributed between so many microbic individuals that each of them, being not sufficiently touched, will not reproduce the principle". ${ }^{87}$ Bordet regarded this as strikingly contradictory to the viral nature of the principle, because a virus would have to multiply abundantly in the presence of an excess of host organisms.

To the adherents of the endogenous theory of the bacteriophage the existence of lysogeny, the apparently spontaneous generation of the bacteriophage, was a crucial argument supporting their point of view. That the bacteriophage could be a parasite was, according to Bordet, totally impossible, because of the spontaneous creation of the bacteriophage in lysogenic bacteria. D'Hérelle, defender of the viral nature of the bacteriophage, explained lysogeny as the consequence of a mixed infection by bacterium and bacteriophage. D'Hérelle stated that such a mixture of a bacterium and an antagonistic bacteriophage was possible because the latter developed resistance against the action of the bacteriophage ${ }^{88} \mathrm{He}$ concluded from the work of Bordet and

86. Jules Bordet, 'Apparition spontanée du pouvoir lysogène dans les cultures pures', Compt. Rend. Soc. Biol, 1924, 90: 96-8.

87. Bordet, op. cit., note 71 above, p. 178. See also Flu, op. cit., note 7 above, p. 34. From this quotation it will be clear that, as far as current knowledge allows. Bordet advocated a somewhat peculiar mechanism for the manner with which a substance exerted its influence on a bacterium. This could probably be due to the fact that he belonged to the "colloidal school", and expressed these ideas in his thoughts on the mechanism of the antigen-antibody reaction. For a general discussion of the latter problem see, for instance, Pauline M. H. Mazurndar, 'The antigen-antibody reaction and the physics and chemistry of life', Bull. Hist. Med., 1974, 48: 1-21; Lewis P. Rubin, 'Styles in scientific explanation: Paul Ehrlich and Svante Arrhenius on immunochemistry', J. Hist. Med., 1980, 35: 397-425.

88. 'Resistance of the bacteria', in d'Hérelle, op. cit., note 18 above, pp. 182-241, especially on pp. 182-8. Because of the development of resistance by bacteria in the presence of bacteriophage, d'Herelle accorded bacteriophage an important role in the evolutionary development of a bacterial culture. He interpreted the interaction between bacteria and bacteriophage as analogous to the obligatory symbiosis between an orchid and a fungus which had been reported by Noël Bernard in 1901 . Orchids are infected through their endotrophic mycorrhizae and the presence of the fungus may be necessary for the germination of the seed. See ibid., footnote on p. 222. Cf. Alan S. Kay, "Noël 
Ciuca that three types of bacterial colonies were possible: (a) ultrapure colonies consisting of resistant bacteria; (b) contaminated colonies consisting of resistant bacteria and bacteriophages ("mixed cultures"); and (c) ultrapure colonies which consisted solely of susceptible bacteria. D'Hérelle based his conclusion that lysogenic bacteria were mixed cultures on his finding that it was, in principle, possible to separate bacteriophages from the bacteria both in naturally occurring and in laboratorymade mixed cultures and that, therefore, in such cultures "bacteriophage corpuscles represent an impurity, in the bacteriological sense of the word". 89 [talics mine.]

Lack of reproducibility was an important problem in the study of lysogeny. This was clear in the exchange of bacterial cultures between Bordet on the one hand and Lisbonne and Carrère on the other, in which the strains were constantly checked for lysogeny with the help of an indicator strain. It was found that a non-lysogenic strain from Bordet's collection remained non-lysogenic in his laboratory in Brussels, but became lysogenic after being cultured in the laboratory of Lisbonne and Carrère in Montpellier for one year. ${ }^{90}$

In December 1930 Bordet delivered his Croonian Lecture for the Royal Society of London. He devoted it to bacteriophage theories and it seems likely that he faced an audience which sympathized with the position he had taken in the controversy. After all, he interpreted the bacteriophage phenomenon in the context of bacterial variation and this subject was being extensively studied in England, for instance by Frederick Griffith and Joseph Arkwright. ${ }^{91}$ Bordet discussed several elements from the rival "virus theory", including the question of whether the bacteriophage was organized, as had been concluded from the existence of plaques. Bordet argued that at least three other hypotheses could also explain the formation of plaques, including the argument that they were the result of variations in the susceptibility of the bacteria: only those Bernard', in Gillispie, op. cit., note 13 above, 1973, vol. 2, pp. 34-5.

89. D'Hérelle, op. cit., note 18 above, p. 238. Cf. Jules Bordet and Mihai Ciuca, 'Évolution des cultures de Coli lysogène', Compt. Rend. Soc. Biol., 1921, 84: 747-8. By "ultrapure" d'Hérelle meant that it was a pure bacterial strain, free of bacteriophage corpuscles; see d'Hérelle, op. cit., note 18 above, p. 204.

90. M. Lisbonne and L. Carrère, 'Sur l'apparition spontanée du pouvoir lysogène dans les cultures pures; a propos d'une note de J. Bordet', Compt. Rend. Soc. Biol, 1924, 90: 265-7

91. The occurrence and behaviour of $R$ and $S$ types of bacteria had been studied by, among orhers, the British researchers Frederick Griffith and Joseph Arkwright. Cf. Joseph A. Arkwright, 'Variation in bacteria in relation to agglutination both by salts and by specific serum', J. Path. Bact., 1921, 24: 36-60; Frederick Griffith, 'The significance of pneumococcal types, J. Hyg., 1928, 27 : 113-59. See also the literature on bacterial variation in note 44 above 
bacteria which were the most susceptible would lyse and thus give rise to the bacterium-free spots. ${ }^{92}$ Bordet also signalled properties of the lytic principle which contradicted those of living micro-organisms ${ }^{93}$ : (a) the behaviour of the principle with respect to antiseptics; (b) the lack of a "lag" phase when, after being stored for a long time, the principle was added to a bacterial culture ("If it were a virus, one would expect the principle to require an appreciable time for the recovery of its vital activity, after such a long period of inaction."); (c) the lytic principle could be neutralized with antiserum in which the complement had been inactivated by heating it to $60^{\circ} \mathrm{C}$. The activity of an antiserum against bacteria ("bacteriolytic" serum) required complement as well as antibody. This difference in the neutralizing mechanism between bacteriophage and bacteria led Bordet to the conclusion that, unlike a bacterium, a bacteriophage was not "organized". 94

The serial transmissibility of the lytic principle, a cornerstone of the virus theory of bacteriophage, could, according to Bordet, also be explained without postulating the existence of a virus. The bacteriophage would stimulate the bacterium to produce a principle which was identical to the cause of the production. For such a process, Bordet referred to an analogy from normal physiology, that of blood coagulation. The coagulation of blood could be initiated by the contact with a foreign body but also by thrombin. When blood solidified, a new amount of the coagulating principle, the thrombin, was liberated. Therefore, once thrombin had been formed, the initial factor (the solid foreign body) was no longer needed, because thrombin could cause the formation of more thrombin. ${ }^{95}$

In his Croonian Lecture Bordet also described some crucial experimental work on the basis of which he concluded that it could not be doubted that bacteriophagy was connected with the physiology of the bacteria. It should be noted that Bordet's definition of this bacterial physiology was broad and included the differentiation of a bacterial culture into bacterial variants. He discussed the development of rough and

92. Jules Bordet, 'Croonian Lecture - The theories of the bacteriophage', Proc. Roy. Soc., London, Ser. B, 1931, 107: 398-417, on pp. 400-1.

93. Ibid., pp. 401-4, especially on pp. 401-2.

94. To d'Hérelle the absence of involvement of complement in the action of antiserum against (ultra)viruses, e.g. bacteriophage, indicated that a different serological mechanism was apparently involved: see 'Immunity against the ultraviruses', in d'Hérelle, op. cit., note 63 above, pp. 349-85.

95. Bordet, op. cit., note 92 above, pp. 405-6. Cf. Jules Bordet and Octave Gengou, 'Recherches sur la coagulation du sang', Ann. Inst. Pasteur, 1903, 17: 822-33. Bordet's diagram of blood coagulation is depicted in Fritz Lieben, Geschichte der physiologischen Chemie, 1935, repr. Hildesheim, Georg Olms Verlag, 1970, p. 309. 
smooth variants ( $\mathrm{R}$ and $\mathrm{S}$ types) of Bacillus coli and the role of weak and strong lytic principles (bacteriophages) in this process, ${ }^{96}$ Bordet had isolated a lytic principle which was active against the $\mathrm{S}$ type while the $\mathrm{R}$ type was relatively insusceptible. This principle he called the weak lytic principle, in contrast to the strong lytic principle which was active against both bacterial types. The term "weak principle", therefore, did not mean that it had a weak activity, but only referred to its "host range". If the weak principle was added to a large quantity of bacteria it could adapt to the $R$ type and become active both against the $S$ and the $R$ forms of the bacteria. It had now become the strong lytic principle. Bordet concluded that the "peculiar characters, the individuality of a given type of microbe, are reflected in the qualities of the principle which it is capable of elaborating". ${ }^{97}$ This he felt to be contradictory to the supposed autonomy of bacteriophage as a filterable virus. The properties and behaviour of the lytic principles which Bordet regarded as incompatible with the notion of the bacteriophage as a virus were the role of the concentration of the lytic principle, and the individuality of the principles in accordance with the nature of the microbial variant by which it was produced. ${ }^{98}$ On the basis of his experiences, Bordet concluded that bacteriophagy was related to the formation of bacterial variants. It has to be emphasized that Bordet regarded the formation of bacterial variants as a process belonging to their normal physiology. Bacteriophagy, as a mutation phenomenon, was a normal physiological process and the lytic power of a bacterial culture was an index of spontaneous differentiation. Bordet saw no necessity to assume the existence of an exogenous virus:

$\ldots$ is it not more rational to think that the virus does not exist, that the intense action of the bacteriophage represents nothing more than the pathological exaggeration of a normal function

96. On solid medium the $S$ type of a bacterium consists of intact, shining colonies with smooth borders; in salt solution the bacterial culture is easily suspendible (homogeneous clouding) while growing homogeneously cloudy in broth. By contrast, the $\mathrm{R}$ form grows on solid medium in rough, dull and wrinkled colonies (larger and flatter than the $\mathrm{S}$ colonies); in salt solution the $\mathrm{R}$ type shows flocculation or sedimentation (autoagglutination) while growth in broth results in a flocculent growth with precipitate.

97. Bordet, op. cit., note 92 above, p. 408.

98. Anne-Marie Moulin points out that Bordet's opinion on specificity can more properly be viewed as a continuity of all possible grades. In the immunological domain Moulin indicated the following sequence of adherents in order from strict specificity to non-specificity: Paul Ehrlich Svante Arrhenius - Karl Landsteiner - Jules Bordet - Ludwik Fleck. See Anne-Marie Moulin, 'Fleck's style', in Cohen and Schnelle, op. cit., note 4 above, pp. 407-19, on p. 412. 
connected with mutations, and that this lysis is, in reality ... a transmissible autolysis? ${ }^{99}$ [Italics mine.]

The decade of Bordet's research which has been briefly discussed here showed some important changes in his ideas on the cause of bacteriophagy. In 1920 he thought he had to explain the d'Hérelle phenomenon as the result of a product of the leukocytes. Transmissible bacterial autolysis would be an inheritable disturbance of the nutrition, a pathological displacement in the assimilating and degrading processes, of the bacteria. This explanation fitted in with the scheme which had been suggested by Metchnikoff for the role of "digestion" and physiology in mechanisms of immunity. The phenomenon of lysogeny played a dominant role in Bordet's change of position in 1923. He now explained the bacteriophage phenomenon as the result of bacterial antagonism between different bacterial species, though shortly afterwards he pointed to processes of bacterial variation within pure cultures. But although he changed his opinion on the cause of the bacteriophage, he continued to interpret bacteriophagy as an aspect of the physiology of bacteria and his work can be characterized as belonging to a physiological research style. His conception of bacterial physiology did not only comprise those aspects which are now thought of as the biochemistry or physiology of bacteria, but also encompassed what is now called bacterial genetics. 100

99. Bordet, op. cit., note 92 above, p. 417 . Bordet expressed the role of mutant formation as follows: "... the total population of a pure culture is the seat of perpetual interreactions between the individuals which compose it. The appearance of the lytic power seems, indeed, to be the index of a spontaneous differentiation, but this power itself contributes to the guidance of evolution in the culture, since it induces modifications in certain receptive types." Ibid., p. 416. André Lwoff characterized Bordet's point of view as: "Everything was physiological heredity." See Lwoff, op. cit., note 7 above, p. 276.

This may be the place to evaluate the work of Frederick Twort in relation to the positions of d'Hérelle and Bordet. From Twort's article on dysentery of 1920 (see note 26 above) it is clear that he, like Bordet, interpreted the bacteriophage phenomenon in the context of bacterial variation or "dissociative phenomena". Twort did not state his ideas about the mechanism which, he thought, underlay this process of bacterial variation. He stated that the observed special forms of dysentery bacilli were "probably not stages in a true life-cycle, as the normal type is not produced in rotation, and it is doubtful if they are mutations. Special types may be produced for performing special work, and types in 'pure culture' may be likened to bees in a swarm." See Twort, op. cit., note 26 above, p. 243. It should be remembered that Twort's 1920 article on dysentery remained unquoted in the field of bacteriophage research (cf. Varley, op. cit.. note 7 above, p. 300, footnote 29).

100. The development towards independence of bacterial genetics from bacterial physiology 


\subsection{THE CONSTRAINING FORCE OF RESEARCH STYLES}

In the 1920s the discussion on the nature of the bacteriophage phenomenon was characterized by a controversy in which both d'Hérelle and Bordet played important roles on opposing sides. The positions they held were inspired by their background knowledge, their reputations and ambitions, by the way they performed their experiments, by their choice of experimental material, etc. D'Hérelie's research was founded upon his notion that a bacteriophage had to be viewed as an autonomous living entity (although he departed from his early notion that it was an ultramicrobe, instead embracing the view that it was a living micell). Bordet developed his study of bacteriophagy from the science of immunity and the study of the physiology of bacteria. The interpretations of the experiments in these contexts were formed and constrained by the choices that were made from available analogies and metaphors.

For d'Hérelle the bacteriophage was as central as the microbe was to Louis Pasteur. He attributed to it, among other things, the following properties: retention of individuality (autonomy), which was proved when the bacteriophage multiplied on different microbes; the organized or complex character of the bacteriophage; and some properties shared by all living organisms, namely, multiplication in a heterologous medium and adaptation. Furthermore, d'Hérelle thought the interaction between bacteria and bacteriophage to be characterized by a struggle for life between bacteriophage and bacteria, the course of which was influenced by adaptation (on the par: 0 . both the bacteriophage and bacterium). The struggle between an infected macroorganism and a pathogenic bacterium depended on the struggle between bacterium and bacteriophage. As the bacteriophage was living, it was impossible that it could arise spontaneously; therefore, lysogeny had to be explained as resulting from a mixture of

showed itself in the work of Joshua Lederberg. In 1951 he wrote that one had to distinguish the situation of an adaptive response being physiological ("a directed change within each bacterial cell") from that of a change in the composition of a bacterial population ("whereby the genetic composition of the culture is altered by differential rates of growth, death or mutations"). See Joshua Lederberg, 'Inheritance, variation, and adaptation', in Bacterial physiology, C. H. Werkman and Perry W. Wilson (eds), New York, Academic Press, 1951, pp. 67-100, on p. 94. In fact, bacterial physiology was to enter the domain of genetics later on, namely in the "operon model" of enzyme synthesis. In this scheme an operator gene, one or more structural genes and a regulator gene determine the synthesis of the enzymes of a particular catabolic or biosynthetic pathway. For a description of this development see for instance 'Gene expression and regulation' in Brock, op. cit., note 7 above, pp. 265-324. For two case studies of the establishment of bacterial physiology in England see Robert E. Kohler, 'Innovation in normal science: bacterial physiology', Isis, 1985, 76: 162-81; and idem, 'Bacterial physiology: the medical context', Bull. Hist. Med, 1985, 59: 54-74 
a bacterium and a bacteriophage in the bacteriological sense of the word. It is this complex of interrelated presuppositions which is denoted as a bacteriological research style, in the sense that bacteriology stands for the study of (ultra)microscopical and autonomous living entities.

That bacteriophagy was an infectious disease of a bacterial population was to a certain extent contradicted by the short time span in which a cloudy bacterial culture was cleared by the lytic principle. Furthermore, the d'Hérelle phenomenon appeared to be linked to the multiplication of the bacteria because, in order to show bacteriophagy, the bacteria had to be living. ${ }^{101}$ Bordet thought transmissible bacterial lysis to be connected to other lytic phenomena which were known to occur in bacteria. Such phenomena were known from humoral immunology and were related to Metchnikoff's view of the physiological and digestive processes which strive towards the integrity of the macro-organism. Furthermore, lytic phenomena were known from the field of bacterial variation, which Bordet thought to be an aspect of the physiology of bacteria. The latter domain included (auto)lytic phenomena and degeneration of ageing bacterial cultures. Bordet claimed that the lytic principle of transmissible lysis was therefore a product of the bacterium, which arose as a result of a shift in the bacterial metabolism. The presumed parasitic nature of the bacteriophage did not agree with the disappearance of the principle in an excess of bacteria; the lytic principle reflected the bacterial type by which it was produced; lysogeny constituted clear evidence that the bacteriophage had to be of endogenous bacterial origin; the transmissibility of the phenomenon could be explained by reference to autocatalytic processes which were known from physiology. According to Bordet, bacteriophagy had to be regarded as a disturbance of the physiology of the bacterium which also found expression in other properties of bacteria, such as changes in behaviour, fermentative properties and outward appearance of the bacterium. This complex of interrelated presuppositions is denoted as a physiological research style.

But the background knowledge on which the development of these research styles was based did not lead only to constraints at a theoretical level. These styles also dictated the method of execution of relevant experiments and the objects of study which had to be selected for valid experiments within the respective research styles. For the bacteriological research style pursued by d'Hérelle virulent bacteriophages had to be used:

101. See Robert Doerr, 'Die Entwicklung der Virusforschung und ihre Problematik', in Handbuch der Virusforschung, Robert Doerr and Curt Hallauer (eds), Vienna, Julius Springer Verlag, 1938, pp. 1-125, on p. 20. 
To effectively demonstrate the [bacteriophage] phenomenon it is necessary to observe the following conditions: (1) To work with a bacterial species which undergoes a rapid bacteriophagy Such a one is the Shiga bacillus. (2) To work with a bacteriophage of maximum activity for the bacterium in question. (3) To utilize a very small number of bacteriophage corpuscles, acting upon a large number of bacteria. ${ }^{102}$ [Italics in the original.]

Bordet's physiological research style required the use of weak and strong principles, which were defined on the basis of their host range. Other parameters which constituted the core of Bordet's experimental design were the concentration of the lytic principle, the period of time during which bacteria were exposed to the principle and the changes the bacteria underwent under the influence of bacteriophage. ${ }^{103}$ The bacteriological and the physiological research styles constrained the possibilities of the methods used, as well as the criteria for judging what was to be taken as scientifically proved and what as unproved.

I will argue elsewhere that the controversy in bacteriophage research which has been analysed here, is a specific example of a general dichotomy between exogenous and endogenous thought styles. ${ }^{104}$ Attempts to bridge this were made by, for instance, Eugène Wollman with his concept of "hereditary factors". ${ }^{105}$ The work of André Lwoff, who in 1950 developed his concept of "probacteriophage", is generally seen as the formation of consensus between the exogenous and endogenous approaches. However, it should be noted that the exogenous character of the bacteriophage was maintained in his concept of probacteriophage. In the following decade, the gap was finally bridged when it was agreed that the genetic material of bacteriophage controls properties of its bacterial host cell. ${ }^{106}$

102. D'Hérelle, op. cit., note 18 above, p. 117.

103. Cf. Varley, op. cit., note 7 above, pp. 184-6.

104. Helvoort, op. cit., note 11 above.

105. Eugène Wollman, 'The phenomenon of Twort-d'Hérelle and its significance', Lancet, 1935, ii: $1312-14$.

106. Salvador E. Luria, 'Bacteriophage genes and bacterial functions', Science, 1962, 136: 68592. 
CHAPTER 5

The Controversy between John H. Northrop and Max Delbrück on the Formation of Bacteriophage: Bacterial Synthesis or Autonomous Multiplication?

CONTENTS

5.1 Winner takes all $\mathbf{1 1 6}$

5.2. The study of bacteriophage in a chemical context 119

5.3. Northrop, bacteriophage, and the problem of protein synthesis $\mathbf{1 2 4}$

5.4. Delbrück, the 'Riddle of Life', and bacteriophage $\mathbf{1 2 8}$

5.5. Delbrück, bacteriophage, and the bacterium as a 'black box' 133

5.6. Northrop and Krueger versus Delbrück in the early 1940s 138

5.7. Northrop, Delbrück, and biochemistry in the late 1940 s 142

5.8. Conclusion: clashing research styles 147

Adapted from

Annals of Science, vol. 49 (1992), pp. 545-575. 
CHAPTER 5

\section{The Controversy between John H. Northrop and Max Delbrück on the Formation of Bacteriophage: Bacterial Synthesis or Autonomous Multiplication?}

\subsection{WINNER TAKES ALL}

Controversies are an appropriate focus for studying the formation of scientific facts. ${ }^{1}$ In a controversy the views of opposing parties are often formulated explicitly. By concentrating on these moments in scientific enquiry, historians of science follow 'science in the making', as distinct from 'science as ready made science'. 2

The controversy that will be analysed in this essay concerns a discussion on bacteriophage between John H. Northrop and Max Delbrück in the 1940s. By then, Northrop was a well-respected scientist who received the Nobel Prize for Chemistry in 1946 for his study of crystalline enzymes. ${ }^{3}$ In the field of bacteriophage research Delbrick was a newcomer but his star would rise fast and in 1969, together with Salvador Luria and Alfred Hershey, he was to receive the Nobel Prize for Medicine. ${ }^{4}$ The work of these three scientists and other members of the so-called 'Phage Group' contributed greatly to the establishment of 'molecular biology' as a scientific discipline. 5

The above-mentioned controversy concentrated on the question of how bacteriophages (now conceived of as bacterial viruses) were formed. Northrop and his

1. For literature on controversies see Chapter 1 of the present study, especially footnote 35.

2. See B. Latour, Science in Action: How to Follow Scientists and Engineers Through Sociery (Milton Keynes, 1987) and Chapters 1 and 7 of the present study.

3. Anonymous, 'Nobel Prize for Chemistry [James Sumner, John H. Northrop and Wendell M. Stanley]', Nature, 158 (1946), 826.

4. G. Stent, 'The 1969 Nobel Prize for Physiology or Medicine [Max Delbrück, Salvador Luria and Alfred Hershey]', Science, 166 (1969), 479-81.

5. J. Cairns, G. S. Stent and J. D. Watson (eds.), Phage and the Origins of Molecular Biology (Cold Spring Harbor, 1966); J. C. Kendrew, 'How Molecular Biology Started', Scientific American, 216 (March) (1967), 141-4; G. Stent, 'That Was the Molecular Biology That Was', Science, 160 (1968), 390-5; N. C. Mullins, 'The Development of a Scientific Specialty: The Phage Group and the Origins of Molecular Biology', Minerva, 10 (1972), 51-82; S. S. Cohen, 'The Origins of Molecular Biology', Science, 187 (1975), 827-30. 
temporary co-worker, Albert P. Krueger, took the view that phage was a product of the bacterium and the formation of phage was to be regarded as bacterial synthesis. Northrop was an expert in the field of enzyme research and he and Krueger thought that the formation of phage was similar to the synthesis of enzymes by bacteria. The autocatalytic formation of enzymes from inactive precursors appeared to them to be an especially fruitful analogy. Delbrück, together with Salvador E. Luria, developed his research following a different analogy. He regarded bacteriophage as a virus of the bacterium and, as a corollary, accepted that viruses were autonomous entities characterized by heritable stability.

From the historiography of molecular biology the picture arises of Delbrück giving the right interpretation of the nature of bacteriophage, while the work of Northrop and his associate Krueger has been severely criticized. In his Path to the Double Helix, Robert Olby wrote 'Delbrück's first task was to improve on the disastrous assay systems used by Northrop and Krueger'. In their Introduction to the History of Virology, Anthony Waterson and Lise Wilkinson wrote that the members of the 'Phage Group' were 'laying the ghost of a certain precursor theory championed by A. P. Krueger'. In the semi-popular book on the history of molecular biology, The Eighth Day of Creation, Luria is cited as claiming that Krueger quantified bacteriophage by means of a "very complicated method, which partly turned out later to be the cause why Krueger got very crazy resuits, results that he interpreted in a very crazy way'. In Delbrück's biography it states that for several years Delbrück's articles 'were largely directed at destroying Northrop and Krueger'. ${ }^{6}$

However, the historian has to be cautious in accepting the accounts that scientists present retrospectively. ${ }^{7}$ One phenomenon is that of 'winner take all'. If the tackling of a scientific problem can be viewed as a race, it should be noted that there are no third and second prizes; he who arrives first will be the sole prizewinner. ${ }^{8}$ Furthermore, there is the observation that personal histories play a role in the

6. R. Olby, The Path to the Double Helix (London, 1974), p. 239; A. P. Waterson and L. Wilkinson, An Introduction to the History of Virology (Cambridge, 1978), p. 107; H. F. Judson, The Eighth Day of Creation: Makers of the Revolution in Biology (London, 1979), p. 53; E. P. Fischer and C. Lipson, Thinking about Science: Max Delbrück and the Origins of Molecular Biology (New York, 1989), p. 125.

7. See, for instance, G. N. Gilbert and M. Mulkay, 'Experiments Are the Key - Participants' Histories and Historians' Histories of Science', Isis, 75 (1984), 105-25; 'Scientists' Histories', in H. Kragh, An Introduction to the Historiography of Science (Cambridge, 1987), pp. 150-8.

8. See 'Winner Take All', in A. Sayre, Rosalind Franklin and DNA (New York, 1978), pp. 156-67. 
justification and emergence of scientific 'specialties'. Such historiography plays a role in gaining money, reputation and rewards, the making of careers, the establishment of departments, and so on. ${ }^{9}$

An important step in the work of Max Delbriick was the development, together with Emory Ellis, of the so-called one-step growth technique for growing bacteriophage. By ingenious manipulation, using dilutions of bacteriophage and bacterium, the multiplication of bacteriophage could be limited to one cycle. ${ }^{10}$ Delbrück concluded from the results obtained with this technique that bacteriophage multiplied in the bacterium and was liberated in a 'burst' by lysis (dissolution) of the bacterium. This methodological technique would become the core of 'clear-cut' experiments by Delbriick and Luria which, in the mid-1940s, became the basis of the success of the 'Phage Group'. The elegance of these experiments and the 'robustness' of the scientific facts that were formulated on these observations raises the question why Northrop and Krueger stuck to their opposing ideas. With this question we have arrived at a general problem in the sociology of scientific knowledge, that is the role of 'experiments' in controversies between different theories, in other words, the role of experiments in the development of theories."

One thesis in the 'relativism' of the present sociology of scientific knowledge is an emphasis on the view that experimental evidence allows more than one theory. This notion is also known as the Duhem-Quine thesis. This thesis, which is based on the work of Pierre Duhem and Willard V. O. Quine, is characterized by Peter Galison as

9. P. Abir-Am, 'Essay Review: How Scientists View Their Heroes: Some Remarks on the Mechanism of Myth Construction', Journal of the History of Biology, 15 (1982), 281-315. A critical analysis of a number of forms of historiography of molecular biology can be found in $\mathrm{P}$. Abir-Am, 'Themes, Genres and Orders of Legitimation in the Consolidation of New Scientific Disciplines: Deconstructing the Historiography of Molecular Biology', History of Science, 23 (1985), 73-117.

10. E. L. Ellis, 'Bacteriophage: One-Step Growth', in J. Cairns, et al. (footnote 5), pp. 53-62. It is useful to point out that Ellis produced the one-step growth curve before he was joined by Delbrück. At the end of his career the latter would write that Ellis 'started studying the growth of this phage and made the first one-step growth curve.' See M. Delbrück, 'Session II: Phage Introduction', in Genes, Cells, and Behavior: A View of Biology Fifty Years Later. Fiftieth Anniversary Symposium of the Division of Biology of the California Institute of Technology, held on November 1-3, 1978, edited by N. H. Horowitz and E. Hutchings, Jr. (San Francisco, 1980), pp. $39-43$ (p. 39). See also E. Ellis, op. cit., p. 58.

11. For recent literature on the role of experiments in science, see footnute 21 of Chapter 1 of the present study. 
the notion that 'experiments confront no single hypothesis, but a web of interrelated beliefs ... [and] an infinite number of auxiliary hypotheses'. Steven Shapin formulated the Duhem-Quine thesis in the expression that in principle all experimental conclusions can be challenged ... ${ }^{12}$

In this article, it will be argued that the controversy between John Northrop and Max Delbrück should not be interpreted as a conflict over the meaning of the one-step growth curve in deciding between the correct theoretical notion of Delbrück and the view of the wrong-headed and 'blind' Northrop. It will be concluded that the controversy was a conflict between two paradigms or research styles as they will be called here. The controversy arose because the research problem, i.e. the formation of bacteriophage, was studied from different contexts. Such contexts correspond to Thomas Kuhn's disciplinary matrices and encompass shared concepts, symbols, apparatus, exemplary experiments, theories, and so on. ${ }^{13}$ The theoretical notions or conceptual networks of these two contexts, indicated for the sake of convenience as physiological and bacteriological contexts, respectively, can be described in terms of Kuhn's 'similarity' and 'dissimilarity' relations.

This case-study shows that the opponents used largely the same terminology but that different conceptual networks were created by applying 'instances' or 'exemplars' in different ways. The various possibilities of linking concepts and instances gave rise to local incommensurability. ${ }^{14}$ It will be shown that the way experiments were performed and evaluated was very important, which is why the respective paradigms will be designated here as research styles. The experimental observations were inconclusive because the opponents interpreted the experiments of both sides on the basis of different research styles.

\subsection{THE STUDY OF BACTERIOPHAGE IN A CHEMICAL CONTEXT}

John H. Northrop received his Ph.D. in 1915, after which he worked with Jacques Loeb in the laboratory for general physiology of the Rockefeller Institute in New

12. P. Galison, How Experiments End (Chicago, 1987), p. 2; S. Shapin, "History of Science and Its Sociological Reconstructions', History of Science, 20 (1982), 157-211 (p. 199, note 9). Cf. J. Golinski, 'The Theory of Practice and the Practice of Theory: Sociological Approaches in the History of Science', Isis, 81 (1990), 492-505; the literature in footnote 20 of Chapter 1 of the present study.

13. T. S. Kuhn. The Structure of Scientific Revolutions, 2nd ed. (Chicago, 1970).

14. B. Barnes, T. S. Kuhn and Social Science (London, 1982); P. Hoyningen-Huene, 'Kuhn's Conception of Incommensurability', Studies in History and Philosophy of Science, 21 (1990), 48192. 
York. After the sudden death of Loeb in 1924, Northrop became a 'full member' of the Institute and he transferred his activities to the Rockefeller Institute laboratories in Princeton, New Jersey. ${ }^{15}$

From 1919 onwards Northrop studied the properties of enzymes such as pepsin and trypsin, concentrating on the kinetic properties of catalytic reactions. To quantify his enzyme preparations, he used the finding that the time necessary to bring about a small, standardized change in the substrate was reciprocal to the concentration of the enzyme. He measured the alteration of substrate as the change in conductivity or viscosity of a solution. ${ }^{16}$ The nature of enzymes was the subject of heated debate in the 1920s. European scientists such as Richard Willstätter and Ernst WaldschmidtLeitz supported the view that enzymes were small organic catalysts, weakly linked to carrier molecules consisting of proteins, carbohydrates or lipids. The crystallization of the enzyme urease from jack beans and its characterization as a protein by James B. Sumner at Cornell University Medical School (in part in Ithaca, New York), strongly contributed to the opinion that enzymes were proteins. ${ }^{17}$

The work of Sumner was an important source of inspiration for Northrop who rounded off his studies of the crystallization of pig pepsin in 1930. In these studies he described the physical and chemical properties of the crystalline enzyme, correlating the catalytic activity of pepsin with the behaviour of the enzyme under numerous fractionation procedures. His experimental techniques included crystallization, saltfractionation, selective destruction of enzymatic activity by alkali or heat, and physicochemical studies by a 'solubility method'. In the early 1930s John Northrop, Moses Kunitz and Roger Herriott extended this research to other proteases like trypsin, which

15. See R. M. Herriott, 'A Biographical Sketch of John Howard Northrop', Joumal of General Physiology, 45 (Part 2) (1962), 1-16 and 253-65; R. M. Herriott, 'John H. Northrop; The Nature of Enzymes and Bacteriophage', Trends in Biochemical Sciences, 8 (1983), 296-7. For a history of the Department of Animal and Plant Pathology at Princeton, New Jersey, see G. W. Corner, A History of the Rockefeller Institute - 1901-1953. Origins and Growth (New York, 1964). Cf. L. E. Kay, 'W. M. Stanley's Crystallization of the Tobacco Mosaic Virus, 1930-1940', Isis, 77 (1986), 450-72.

16. See, for instance, J. H. Northrop, 'The Dynamics of Pepsin and Trypsin [Lecture delivered on 14 November 1925.]', Harvey Lectures, 21 (1927), 36-76.

17. J. B. Sumner, 'The Isolation and Crystallization of the Enzyme Urease', Journal of Biological Chemistry, 69 (1926), 435-41. Cf. J. B. Sumner, 'The Story of Urease', Journal of Chemical Education, 14 (1937), 255-9; C. F. Cori, 'James B. Sumner and the Chemical Nature of Enzymes', Trends in Biochemical Sciences, 6 (1981), 194-6; A. L. Dounce and P. Z. Allen, 'Fifty Years Later: Recollections of the Early Days of Protein Crystallization', idem, 13 (1988), 317-20; A. B. Costa, 'James Sumner and the Urease Controversy', Chemistry in Britain, 25 (1989), 788-90. 
was crystallized in $1932 .{ }^{18}$ It was this chemical context of the isolation and study of enzymes within which Northrop broached the study of bacteriophage.

The term bacteriophage was coined by Félix d'Hérelle for a filterable principle that could lyse (dissolve) a bacterial culture and could be serially transmitted to fresh bacterial cultures. This serial transmissibility was interpreted by d'Hérelle as proof of the multiplication of bacteriophage in this process. In the 1920 s a fierce controversy arose over the nature of bacteriophage, during which numerous hypotheses were proposed. ${ }^{19}$ The most important positions included that which saw bacteriophage as a living organism and that which interpreted phage as a product of the bacterium. In the latter interpretation the phenomenon of lysogeny played a crucial role. Lysogeny was defined as the growth of bacteria and bacteriophage in a bacterial culture; furthermore, it proved to be impossible to free lysogenic bacteria from bacteriophage. ${ }^{20}$

In the United States the controversy on the nature of bacteriophage was strongly influenced by André Gratia, who became a friend of Northrop's. In the early 1920s, Gratia worked at the Rockefeller Institute in New York and defended the view that bacteriophage was lifeless and a product of the bacterium. 21 The view of bacteriophage as a bacterial product with the property of multiplication constituted for Northrop an interesting research problem, which was picked up by Northrop's coworker Albert P. Krueger.

The first task Krueger set himself was to develop methods of quantifying bacterium and bacteriophage. The antagonism of bacteriophage to bacteria made Krueger conclude that the classical techniques for quantifying bacteria (e.g. colony culture and dilution technique) were not appropriate. He therefore developed a centrifugation-sediment method, in the course of which thick bacterial suspensions

18. See the reviews J. H. Northrop, 'The Chemistry of Pepsin and Trypsin', Biological Reviews, 10 (1935), 263-82; J. H. Northrop, 'Isolation and Properties of Pepsin and Trypsin [Lecture delivered on 16 May 1935.]", Harvey Lectures, 30 (1936), 229-70.

19. See, for instance, 'Hypotheses Concerning the Nature of the Bacteriophage', in F. d'Hérelle, The Bacteriophage and its Behaviour (Baltimore, 1926), pp. 309-28.

20. Cf. A. Lwoff, 'Lysogeny', Bacteriological Reviews, 17 (1953), 269-337 and Chapter 6 of the present study.

21. A. W. Varley, Living Molecules or Autocatalytic Enzymes: The Controversy over the Nature of Bacteriophage, 1915-1925, (Ph.D. Thesis, University Microfilms International, no. 8711282, University of Kansas, 1986) and T. van Helvoort, 'Bacteriological and Physiological Research Styles in the Early Controversy on the Nature of the Bacteriophage Phenomenon", Medical History, 36 (1992), 243-70; included as Chapter 4 of the present study. For the influence of Gratia on early bacteriophage research in the United States see A. Varley, op. cit., pp. 282-97. 
could be assayed with a total error in the method smaller than $2 \%$ and diluted suspensions with an error of about 5\%. The two standard techniques for quantitative estimation of bacteriophage (i.e. the serial dilution technique and the plaque assay) were not appropriate either, according to Krueger. He sought to solve this problem by means of an analogy to the principle used by Northrop in quantifying enzymes: the reciprocal relationship between concentration and the time required to obtain a standardized change of substrate. Krueger developed a measuring method for bacteriophage by assuming a reciprocal relationship between the concentration of bacteriophage and the time required to reduce a certain concentration of growing phage-susceptible bacteria to a specified turbidity endpoint. This method for the quantitative analysis of bacteriophage was called the activity assay or the "time method'.22

These newly developed quantitative methods were used by Krueger and Northrop to study the reaction of phage $(\mathrm{P})$ and bacterium $(\mathrm{B})$, performing their kinetic experiments over periods of time ranging from three or eight hours to several days. They found that in their experimental system, using Staphylococcus aureus, the bacterial culture lysed when the ratio of phage to bacteria reached $125(\log \mathrm{P} / \mathrm{B}=2.1)$. Thus, it was not the absolute concentration of bacteriophage that determined the moment of lysis, but the ratio $\mathrm{P} / \mathrm{B}$. Their analysis also revealed a linear relationship between the phage concentration at time zero $\left(\mathrm{P}_{\mathrm{o}}\right)$ and the time at which lysis of the culture occurred. They concluded that this justified their speculative use of the parameter $t_{\text {lysis }}$ as a measure of phage concentration at time zero. Krueger and Northrop concluded that the main events in the phenomenon of bacteriophagy could be expressed in mathematical equations. ${ }^{23}$

To Northrop these results meant the justification of his assumption that bacteriophage had to be studied within the context of biological chemistry and did not belong to bacteriology. The work of Krueger and Northrop on bacteriophage appeared to belong to the same domain as the latter's earlier chemical studies of enzymes. The hypothesis that they sought to refute was that bacteriophage was a living and complex micro-organism. An example of the evidence on which they based this refutation was the equilibrium they had found between intracellular and extracellular fractions of

22. A. P. Krueger, 'A Method for the Quantitative Estimation of Bacteria in Suspensions', Journal of General Physiology, 13 (1930), 553-6; idem, 'A Method for the Quantitative Determination of Bacteriophage', op. cit, 557-64.

23. A. P. Krueger and J. H. Northrop, 'The Kinetics of the Bacterium-Bacteriophage Reaction', Journal of General Physiology, 14 (1931), 223-54. 
bacteriophage, which they commented on as 'not at all typical of the distribution one would expect if bacteriophage is a comparatively complex substance'. ${ }^{24}$ It was also corroborated by Krueger's follow-up studies of the distribution, adsorption and diffusion of bacteriophage. Clearly, the formation of bacteriophage belonged to the field of chemistry and physical chemistry. For the reaction between a bacterium and bacteriophage Krueger preferred the hypothesis that the mechanism of adsorption was a process of diffusion into the bacterial cell. ${ }^{25}$

Krueger, who moved to the University of California at Berkeley in 1931, summarized his views on bacteriophage in 1936. He judged that d'Hérelle's view of the multiplication of bacteriophage was certainly mistaken. The latter had defended a scheme in which the first step was the entering of phage into the cell, where it multiplied and was liberated in the next step with lysis of the bacterial cell. Krueger had at least two strong arguments for rejecting this scheme. First, he had observed that under the influence of a concentrated phage suspension a bacterial culture could lyse without growth of bacteriophage. His second argument was that the formation of bacteriophage was determined by bacterial reproduction and not by the lysis of the bacterium. ${ }^{26}$

The elements in the research of Northrop and Krueger that played an important role in their controversy with Delbruick have now been introduced. They can be summarized as follows: (a) The research problem of whether bacteriophage had to be conceived of as a complex and autonomous entity, multiplying at the expense of bacteria and belonging to the field of bacteriology; or the notion of phage being nonliving and a product of the bacterium. The latter hypothesis was defended by Krueger and Northrop, who studied phage with physicochemical methods. (b) The formation of bacteriophage was in their view to be studied as part of the physiology of the bacteria. (c) When phage was produced by the bacterium, the lysis of the latter was a process of only secondary importance. Concerning the origin of bacteriophage, Krueger thought it most probable that phage was a non-living entity derived in some way from the bacterium and capable of causing the production of more of itself when brought into contact with susceptible organisms. ${ }^{27}$

24. A. Krueger, et al. (footnote 23), 241.

25. A. P. Krueger, 'The Sorption of Bacteriophage by Living and Dead Susceptible Bacteria: I. Equilibrium Conditions', Journal of General Physiology, 14 (1931), 493-516.

26. A. P. Krueger, 'The Nature of Bacteriophage and its Mode of Action', Physiological Reviews, 16 (1936), 129-72 (pp. 143-8).

27. A. Krueger (footnote 26), 160-3. 
That the formation of phage was linked to bacterial physiology and that the process of bacterial lysis was only the result of phage production, was also maintained by Jacques Bronfenbrenner, doyen of American bacteriophage researchers in the 1920s. In 1928 he wrote in an important review that 'phage, far from being the product of lysis, is regenerated during the stage of active multiplication of susceptible bacteria preceding the lysis'. ${ }^{28}$ [Italics mine.]

The views of Northrop and Krueger of the manner in which the formation of bacteriophage might be linked to the physiology of bacteria was strongly influenced by Northrop's research of enzymes in the early 1930s. His research group was by then deeply involved in investigations of the formation of active enzymes from inactive precursors. These results were generalized to a 'precursor theory' of the synthesis of proteins. It goes without saying that these findings were immediately applied to the formation of bacteriophage by the bacterial cell.

\subsection{NORTHROP, BACTERIOPHAGE AND THE PROBLEM OF PROTEIN SYNTHESIS}

The successful kinetic and chemical studies of enzymes by Northrop and his coworkers in the 1920s were followed by new achievements in the early and mid-1930s. Chemical isolation procedures resulted in crystalline products which, however, showed no enzymatic activity. It was soon revealed that these products were precursors of those proteins that did show enzymatic activity. In some cases active enzyme could be isolated by treating these preparations with pure proteolytic enzymes. In this way, chymotrypsinogen could be activated by trypsin to chymotrypsin while trypsinogen was turned into trypsin by this enzyme. The later activation was thus autocatalytic, which was also found for the conversion of pepsinogen into pepsin. ${ }^{29}$ The concept of autocatalysis was well known in physiology, especially from the research into the process of blood coagulation. ${ }^{30}$ It would become a central metaphor

28. J. J. Bronfenbrenner, 'Virus Diseases of Bacteria - Bacteriophagy', in Filterable Viruses, edited by T. M. Rivers (London, 1928), pp. 373-414 (p. 389).

29. M. Kunitz and J. H. Northrop, 'Isolation of a Crystalline Protein from Pancreas and its Conversion into a New Crystalline Proteolytic Enzyme by Trypsin', Science, 78 (1933), 558-9; M. Kunitz and J. H. Northrop, 'The Isolation of Crystalline Trypsinogen and its Conversion into Crystalline Trypsin', idem, 80 (1934), 505-6; R. M. Herriott and J. H. Northrop, 'Isolation of Crystalline Pepsinogen from Swine Gastric Mucosae and its Autocatalytic Conversion into Pepsin', idem, 83 (1936), 469-70. See also S. S. Cohen, 'Moses Kunitz', in Dictionary of Scientific Biography; Suppl. II, edited by F. L. Holmes (New York, 1990), pp. 515-8.

30. Cf. J. Bordet and O. Gengou, 'Recherches sur la Coagulation du Sang', Annales de I'Institut Pasteur, 17 (1903), 822-33. In the first half of the twentieth century the concept of 
in Northrop's research on the synthesis of proteins.

Most of the enzymes that Northrop had studied were proteolytic enzymes, i.e. enzymes that hydrolysed proteins. In the 1930 s it was not unusual to attribute to these degrading enzymes a role in the processes of synthesis of proteins as well. Prior to the early 1940s it was not established whether there were special enzymes in the cell that were involved in the synthesis of enzymes and proteins in general. ${ }^{31}$ To Northrop the mechanism of autocatalysis in the formation of active enzymes suggested a working hypothesis for protein synthesis in general, and it also served as an analogy for the formation of bacteriophage. Furthermore, the field of virus research showed dramatic progress at the Princeton Laboratories of the Rockefeller Institute. In the early 1930 s Richard E. Shope had discovered swine influenza virus as well as papilloma viruses in rabbits. ${ }^{32}$ In plant pathology, Wendell M. Stanley achieved a breakthrough by isolating tobacco mosaic virus (TMV). This chemist had purified TMV and obtained a crystalline product that he characterized as a globulin (protein). Under Northrop's influence Stanley suggested that TMV could be produced in the plant by an autocatalytic process; a suggestion that Stanley withdrew again in 1937,33

autocatalysis would be the preferred explanation within the chemical domain for the production of more of the same. In chemistry, the prototype of autocatalysis was the growth of crystals in saturated mother liquor and in cytology the formation of chromatin material was conceived of by some scientists as an autocatalytic process. Cf. L. T. Troland, 'Biological Enigmas and the Theory of Enzyme Action', American Naturalist, 51 (1917), 321-50; A. W. Ravin, 'The Gene as Catalyst; The Gene as Organism', Studies in the History of Biology, 1 (1977), 1-45.

31. Paul Zamecnik, who worked with Max Bergmann, recalled how Fritz Lipmann shocked him by asking whether Zamecnik 'really thought the proteolytic enzymes had anything to do with protein synthesis.' See P. Zamecnik, 'The Machinery of Protein Synthesis', Trends in Biochemical Sciences, 9 (1984), 464-6 (p. 464). The work of Max Bergmann is discussed in J. S. Fruton, 'Early Theories of Protein Structure', in P. R. Srinivasan, J. S. Fruton and J. T. Edsall (eds.), 'The Origins of Modern Biochemistry: A Retrospect on Proteins', Annals of the New York Academy of Sciences, 325 (1979), 1-375 (pp. 1-18). The research on the mechanism of protein synthesis is described in, for instance, P. Zamecnik, 'Historical Aspects of Protein Synthesis', in op. cit., pp. 269-301; F. Lipmann, 'A Long Life in Times of Great Upheaval', Annual Review of Biochemistry, 53 (1984), $1-33$.

32. R. E. Shope, 'Swine Influenza: MI. Filtration Experiments and Etiology', Journal of Experimental Medicine, 54 (1931), 373-85; R. E. Shope, 'A Filtrable Virus Causing a Tumor-like Condition in Rabbits and its Relationship to Virus Myxomatosum', op. cit., 56 (1932), 803-23; R. E. Shope and E. W. Hurst, 'Infectious Papillomatosis of Rabbits', op. cit., 58 (1933), 607-24.

33. W. M. Stanley, "Isolation of a Crystalline Protein Possessing the Properties of TobaccoMosaic Virus', Science, 81 (1935), 644-5; W. M. Stanley, 'The Reproduction of Virus Proteins', 
Northrop again became interested in bacteriophage research because of these exciting developments in the field of filterable viruses. However, it should be noted that he did not regard bacteriophage as a 'prototype' of viruses. In fact, he felt that some viruses (e.g. tobacco mosaic virus) had to be distinguished from the 'real viruses', which were small micro-organisms; the multiplication of the viruses of a 'chemical nature' [my terms] could be explained by a process of autocatalysis. As a consequence of this distinction he did not speak of bacteriophages as bacterial viruses. Northrop took up the study of bacteriophage in the way that had brought him success with enzymes, i.e. by isolation. To quantify anti-staphylococcus phage he used a 'modification of Krueger's accurate titration method' and for the isolation Northrop and his associates treated about 35000 litres of crude phage solution and performed many thousands of phage activity assays. Using denaturation, adsorption, and diffusion studies, Northrop identified phage activity with the isolated protein and determined the minimum quantity of bacteriophage needed for the production of lysis. He calculated a molecular weight for anti-staphylococcus bacteriophage of $300 \times 10^{6}$ and concluded from his results that the presence of 'one or, at most, very few phage molecules (particles) can be detected' ${ }^{34}$ Northrop claimed that formation of bacteriophage could be explained without the hypothesis of a living agent:

[T] he assumption that the living host cells synthesize an inert 'normal' protein which is changed to the active phage by an autocatalytic reaction accounts for the observed facts as well as does the far more complicated series of assumptions involved in the hypothesis that the phage itself is a living organism. ${ }^{35}$

As was already mentioned above, Wendell Stanley withdrew his suggestion that tobacco mosaic virus could be synthesized in a process of autocatalysis in 1937. For this he had two arguments: first, a precursor had been isolated in the case of autocatalytic enzymes and second, this process could be obtained without the presence of living cells. In the case of TMV, none of these circumstances could be obtained. ${ }^{36}$ American Naturalist, 72 (1938), 110-23. See also L. Kay (footnote 15) and T. van Helvoort, 'What is a Virus? The Case of Tobacco Mosaic Disease'. Studies in History and Philosophy of Science, 22 (1991), 557-88; included as Chapter 2 of the present study.

34. J. H. Northrop, 'Concentration and Partial Purification of Bacteriophage', Science, 84 (1936), 90-1; J. H. Northrop, 'Concentration and Purification of Bacteriophage', Journal of General Physiology, 21 (1938), 335-66 (p. 336 and p. 343, respectively).

35. J. Northrop (1938) (footnote 34), 362.

36. See W. Stanley (1938) (foutnote 33). 
Thus, it will be no surprise that Krueger and Northrop tried by any means to show the presence of a phage precursor and to show growth of phage in the absence of active bacterial metabolism, to fulfill the analogy with autocatalytic enzymes ${ }^{37}$

Krueger did not succeed in producing bacteriophage without bacterial growth until 1937. However, by manipulating $\mathrm{pH}$ and temperature values, he succeeded in keeping the 'bacterial substrate' at rest while at the same time observing an increase in the amount of bacteriophage. From this he concluded that the production of bacteriophage could be studied like 'any other cellular mechanism of enzyme formation under conditions which set it apart from the complexities of cellular growth'.38

In the late 1930s, Krueger's attempts to find a phage precursor seemed to come to fruition. Suspensions of staphylococci were 'activated' by growing them in a medium with an excess of oxygen, after which the bacteria were cooled down to $5^{\circ} \mathrm{C}$. Then bacteriophage was added and after an initial period of 5 minutes, Krueger and his coworkers observed a tenfold increase in bacteriophage in comparison to control samples. This confirmed their conclusion that it was now reasonably certain that 'phage is not an autonomous living agent, at least as judged by the criteria of classical physiology'. ${ }^{39}$ [Italics mine.]

Northrop studied the supposed similarity of phage formation to the synthesis of normal cellular enzymes along another line of approach because of the difficulty of obtaining an increase in the amount of bacteriophage in the absence of metabolizing bacterial cells. Northrop recognized a parallel between the phenomenon of lysogeny and the synthesis of adaptive enzymes. Hence he studied the increase in phage concentration and the quantity of an extracellular enzyme (gelatinase) in lysogenic and in susceptible cultures of Bacillus megaterium. Northrop concluded that the bacteriophage was produced during the growth of cells and not during lysis. Moreover, he found that in a small $\mathrm{pH}$ zone around 5.5 no increase in bacteria occurred, while a rise in the amount of phage could be observed. ${ }^{40}$

37. J. H. Northrop, 'Chemical Nature and Mode of Formation of Pepsin, Trypsin and Bacteriophage', Science, 86 (1937), 479-83; J. H. Northrop, 'The Formation of Enzymes', Physiological Reviews, 17 (1937), 144-52.

38. A. P. Krueger, 'The Mechanism of Bacterophage Production', Science, 86 (1937), 379-80 (p. 380).

39. A. P. Krueger and D. M. Baldwin, 'Production of Phage in the Absence of Bacterial Cells', Proceedings of the Society for Experimental Biology and Medicine, 37 (1937), 393-5; A. P. Krueger and J. H. Mundell. 'The Demonstration of Phage Precursor in the Bacterial Cell', Science, 88 (1938), 550-1: A. P. Krueger and E. J. Scribner, 'Intracellular Phage Precursor', Journal of General Physiology, 22 (1939), 699-717 (p. 699). 


\subsection{DELBRÜCK, THE 'RIDDLE OF LIFE', AND BACTERIOPHAGE}

Max Delbrück obtained his Ph.D. at the University of Berlin, after which he went to Copenhagen in 1931 to study nuclear physics with Niels Bohr. After a year, he returned to Berlin to work for five years at the Kaiser Wilhelm Institut für Chemie.41 In this period Delbrïck, together with Nikolai Timoféeff-Ressovsky and K. Zimmer, published the so-called 'green paper' in which his contribution was an 'atomic model' for gene mutations. In this contribution Delbrück concluded that a gene mutation could be understood as a certain change (an 'Elementarprozeß im Sinne der Quantentheorie') in a complicated 'bonding pattern of atoms' ('Atomverband'). In the concluding section, the three authors stated that a gene seemed to be autonomous relative to other genes. ${ }^{42}$

In 1937 Delbrück received a Rockefeller fellowship under the all-embracing title 'Mathematical-Physical Investigation of Tissues, Cells and Molecules' which allowed him to go to the United States for a year. Before leaving, he summarized his ideas on the study of the processes of life in his 'Preliminary Write-up on the Topic Riddle of Life'. In this note he discussed the relevance of the 'recent results of virus research for a general assessment of the phenomena peculiar to life'. First and foremost, he stated that viruses were large molecules with well defined atomic composition, as he concluded from experiments of recrystallization and electrophoresis of certain plant viruses. Second, Delbrück favoured the autonomy of viruses relative to the host cell. He claimed multiplication to be a property of viruses, defining them as living

40. J. H. Northrop, 'Increase in Bacteriophage and Gelatinase Concentration in Cultures of Bacillus Megatherium`, Journal of General Physiology, 23 (1939), 59-79. In contrast to his earlier experiments with bacteriophage, Northrop now used the plaque technique to quantify phage because the lysis of $B$. megaterium was too slow and incomplete to allow accurate determination of the time required for lysis.

41. U. Winkler, 'Max Delbrück 1906 bis 1981', Naturwissenschaftliche Rundschau, 34 (1981), 255-6; G. S. Stent, 'Max Delbrück, 1906-1981', Genetics, 101 (1982), 1-16; W. Hayes, 'Max Ludwig Henning Delbrück - 4 September 1906-10 March 1981', Biographical Memoirs of Fellows of the Royal Society، 28 (1982), 58-90; W. Hayes, 'Max Delbrück and the Birth of Molecular Biology', Social Research, 51 (1984), 641-73; L. E. Kay, 'Conceptual Models and Analytical Tools: The Biology of Physicist Max Delbrück', Journal of the History of Biology, 18 (1985), 207-46; E. Fischer, et al. (footnote 6).

42. M. Delbrück, 'Atomphysikalisches Modell der Genmutation', in N. W. TimoféeffRessovsky. K. G. Zimmer and M. Delbrück, 'Über die Natur der Genmutation und der Genstruktur', Nachrichten von der Gesellschaft der Wissenschaften zu Göttingen, Mathematisch-Physikalischen Klasse, 6 (1) (1935), 189-245 (223-34); quotation on p. 234. 
organisms. Or, the other way around, the autonomy and the living character of a virus were expressed in its multiplication. According to Delbrück, considering viruses as autonomous was legitimate because it appeared impossible to him that the "enzyme system of the host could be modified in such a far-reaching way by the injection of a virus'. Thus, the multiplication of a virus was an 'autonomous accomplishment of the virus, for the general discussion of which we can ignore the host'. [Italics mine.] In conclusion he stated that the multiplication of viruses was nothing else but a certain form of 'primitive replication of genes, the segregation of which from the nourishment supplied by the host should in principle be possible'. ${ }^{43}$

Delbrück arrived in New York in September 1937 and he used the first few months to look for a proper research subject. He visited Milislav Demerec's Genetics Department at the Carnegie Institution in Cold Spring Harbor, Johns Hopkins University in Baltimore, the laboratories of the Rockefeller Institute in Princeton (New Jersey) and Thomas Morgan's laboratory at the California Institute of Technology (Caltech) in Pasedena. With Morgan's Drosophila group he could have continued his research of a physical model for gene mutations. However, he chose another subject because he stumbled on bacteriophage by accident. ${ }^{44}$

In Morgan's laboratory, Delbrück met the chemist Emory Ellis, who worked on bacteriophage in the context of cancer research. It was known that some tumours could be transmitted by cell-free filtrates and thus were thought to be caused by viruses. ${ }^{45}$ Therefore, Ellis thought that a greater knowledge of the nature of viruses could be useful in understanding cancer diseases, and he chose phage as a model. Delbrück was immediately charmed by the simplicity of the experiments and in 1939 they jointly published the technique of the one-step growth curve and the first results of this method with $E$. coli. The method was based on the use of a virulent bacteriophage, a young and fast-growing bacterial culture, and a high concentration of bacteria. In this way, adsorption of only one particle per bacterium was obtained after which the suspension was diluted to prevent adsorption of newly produced phage to

43. The note 'Preliminary Write-up' was reprinted as an appendix with Delbrück's Nobel Lecture: 'A Physicist's Renewed Look at Biology: Twenty Years Later', Science, 168 (1970), 1312 5 (pp. 1314-5). A strong influence from the research on plant viruses, e.g. the work of Wendell Stanley on tobacco mosaic virus, can be recognized in Delbrück's view on the nature of viruses. Cf. L. Kay (footnote 15); L. E. Kay, 'Laboratory Technology and Biological Knowledge: The Tisclius Electrophoresis Apparatus, 1930-1945', History and Philosophy of the Life Sciences, 10 (1988), 5172; T. van Helvoort (footnote 33).

44. E. Fischer, et al. (footnote 6), 105-30.

45. Cf. the work of Richard E. Shope, cited in footnote 32. 
other bacteria. Growth of bacteriophage was limited to one cycle, so the process was prevented from becoming diffuse and normally an experiment lasted less than two hours. Parameters which could be shown with such one-step growth curves included the adsorption of the phage on the bacterium, the 'latent period' during which phage particles grew upon or within the bacterium, and the 'burst size' which was the total yield of phage particles after multiplication of phage and the lysis of one bacterium. ${ }^{46}$

The Rockefeller Foundation was advised by Thomas Morgan to continue Delbrïck's fellowship for another year, while Ellis had to leave because the relevance of bacteriophage research for cancer was questioned by his financiers. Delbrück's research during his second 'fellowship' resulted in two articles that were both based on the one-step growth technique and were published in the Journal of General Physiology in 1940.

The first article concerned the adsorption of bacteriophage to the bacterial cell and the physiological circumstances that influenced the bacterial host. Factors that influenced the one-step growth curve were the size of the bacterium - which in turn depended on the growth phase of the bacterium - and the mobility of the bacterium. ${ }^{47}$ The second article concerned the growth of bacteriophage and the lysis of the host. Delbrück claimed that bacteriophage could cause two kinds of lysis, viz., 'lysis-from-without' and 'lysis-from-within'. The process of 'lysis-from-within' represented the course that Ellis and Delbrück had described in their one-step growth curve. In the bacterial cell phage particles multiplied until a limiting value was reached, after which they were released by a sudden destruction of the protoplasm membrane. With this form of lysis no deformation of the cell membrane was observed. For that situation in which the number of bacteriophages was much greater than the number of bacteria, Delbrück introduced a new term, namely, 'lysis-from-without'. The bacteriophages were absorbed in great numbers until a certain limit was reached. They

46. E. L. Ellis and M. Delbrück, 'The Growth of Bacteriophage', Journal of General Physiology, 22 (1939), 365-84. Later on, the steps in the one-step growth curve would be defined more precisely as the 'latent period' or 'constant period' during which no increase of phage particles was observed, the 'rise period' during which the number of phage particles increased and the 'saturation period' in which one could define the 'burst size'. Cf. A. H. Doermann, 'The Intracellular Growth of Bacteriophages: I. Liberation of Intracellular Bacteriophage T4 by Premature Lysis with Another Phage or with Cyanide', idem, 35 (1952), 645-56; E. Ellis (footnote 10); T. D. Brock, The Emergence of Bacterial Genetics (Cold Spring Harbor, 1990), pp. 120-2.

47. M. Delbrick, "Adsorption of Bacteriophage under Various Physiological Conditions of the Host', Journal of General Physiology, 23 (1940), 631-42. 
attacked the cell in such a way that it swelled, changed into a spherical body and finally lysed. ${ }^{48}$

In the latter article Delbrück formulated a hypothesis that was regarded as an answer to two essential questions within bacteriophage research: how does the bacteriophage multiply? and what is lysogeny? The hypothesis Delbrück formulated on these questions was suggested by his finding that the 'burst size' (the maximum yield of bacteriophage by bacterium) equalled the number of bacteriophages that could be adsorbed by the bacterium (its adsorption capacity). Delbrück hypothesized that a material connection might exist between a bacterial constituent $b$, which adsorbed bacteriophage on the one hand, and the newly formed bacteriophage on the other. $\mathrm{He}$ proposed the following process: $b$ could be a bacterial constituent which, without the help of the bacteriophage, was produced continuously by the bacterium. This constituent was identical to or was part of a precursor, which under certain circumstances was turned into bacteriophage. A complex of the bacterial constituent with bacteriophage $(b P)$ could be the catalyst which, in the cell, turned product $b$ into bacteriophage. ${ }^{49}$

Based on this hypothesis of the multiplication of bacteriophage Delbrück presented an explanation of the phenomenon of lysogeny. He defined this phenomenon as the process by which bacteria could grow in the presence of bacteriophage without undergoing the process of lysis. Delbrück postulated that in phage-susceptible bacteria the turnover of $b$ into phage (catalysed by $b P$ ) was faster than the production of $b$ in the cell, which thus lysed. In case of a lysogenic bacterial strain, $b$ would be produced faster than it was converted into phage, and as a result both the bacterium and the bacteriophage could grow. ${ }^{50}$

We can now summarize the presuppositions in Delbrück's research on bacteriophage, helped by a review of this subject that Delbruick published in 1942. From his 'Write-up' note it is evident that Delbrück interpreted viruses as the most simple biological entities. The heredity of biological organisms was laid down in their genes, so a virus had to be the most elementary level at which genes could be studied.

48. M. Delbrück, 'The Growth of Bacteriophage and Lysis of the Host', Journal of General Physiology, 23 (1940), 643-60. Gunther Stent thought it probable that 'lysis-from-without' was the result of digestion of the bacterial cell wall by lytic enzymes present in the added lysate either in 'soluble' form or attached to phage particles; see G. S. Stent, Molecular Biology of Bacterial Viruses (San Francisco, 1963), p. 80. Compare Delbrück's position regarding 'lysis-from-without' with that of Krueger in section 2 and the literature of footnote 26 above.

49. M. Delbrück (footnote 48), 645.

50. M. Delbrück (footnote 48), 645. 
Delbrück, Timoféeff-Ressovsky and Zimmer had concluded in the 'green paper' that a gene had to be a 'bonding pattern of atoms'. Furthermore, research into the physicochemical properties of plant viruses in particular corroborated the notion that viruses could be thought of as molecules, in fact as nucleoproteins.

In the 1942 review Delbrück summed up seven arguments that would justify the classification of bacteriophages as belonging to the viruses (besides plant and animal viruses). These included the following observations: the fact that the reproduction of viruses depended on actively metabolizing host cells; the host specificity of viruses, the fact that the host/virus relationship ranged from complete latency to total destruction of the host cell. Furthermore, physical studies had shown that bacteriophages and viruses were of the same order of size, and probably had to be characterized as nucleoproteins. On the basis of this general view of bacteriophages as bacterial viruses Delbrück stressed that two problems were fundamental. First, the biochemical basis of the specific relationship between the bacteriophage and its host (cell), and second, the manner in which the reproduction of bacteriophage took place. Delbruick stated that the latter question consisted of two parts: (i) the relation between the multiplication of bacteriophage and the biochemical functions in the host cell and (ii) the nature of the process that secured the 'accurate reproduction of the virus itself' 51

In the meantime, Delbrück had changed his opinion on the autonomy of viruses. In 1937 he had written that it was improbable that the metabolic machinery of the host could be directed in such a way that virus was produced. In 1942 he stated that apparently an intimate relationship existed between the bacterial machinery and virus growth:

One often hears the view expressed, particularly among scientists who work with animal and plant viruses, that the cell provides a suitable nutrient medium for the virus and that the virus grows in this medium as a bacterium would grow in a cell-free nutrient medium. But the indications are that the dependence of the virus on the cell goes decper. (...) The virus makes use of the metabolic machinery of the cell for its own needs. 52

Delbrück's presupposition that bacteriophage, as a virus of a bacterium, developed autonomously thus seemed to have been disproved. In fact, the autonomy of a virus would later be reformulated in the sense that they were genetically autonomous (a view

51. M. Delbrück. 'Bacterial Viruses (Bacteriophages)', Advances in Enzymology, 2 (1942), 1 32 (pp. 2-4)

52. M. Delbrück (footnote 51). 
that was criticized soon after it was formulated). However, other suppositions were also to be dismissed during the following years. Bacteriophages would be shown to be more complex than was concluded from the analogy with physicochemical studies of the well-defined nucleoprotein molecules that constituted the plant viruses.

Delbrück moved to Vanderbilt University on New Year's Day 1940, where he accepted a job in the Physics Department. At the end of 1940, Delbriick met Salvador E. Luria, who worked at Columbia University. Luria, who had been trained as a physician in Italy, had worked in the laboratory of Enrico Fermi. Furthermore, he had done a study of the effect of radiation on bacteriophage. ${ }^{53}$ The meeting between Luria and Delbrück resulted in a co-operative effort to study bacteriophages.

\subsection{DELBRÜCK, BACTERIOPHAGE, AND THE BACTERIUM AS A 'BLACK BOX'}

Delbrück assumed that the one-step growth experiment would be a powerful technique for the study of the multiplication of bacteriophage. As will be argued in this section, however, the technique as he used it had some limitations. Delbrück and Luria studied the multiplication of phage as a process of 'input' and 'output' of the bacterium, with the latter being treated as a 'black box'. To analyse the multiplication process within the 'black box' they studied the simultaneous infection of one bacterium by more than one bacteriophage. Assuming an autonomous development of phages in the bacterial cell, Delbrück expected simultaneous and independent multiplication of both phages.

To detect the multiplication of two different bacteriophages they needed a technique to quantify both phages independently. For this purpose, they used 'indicator strains', i.e. bacterial strains that were susceptible to one kind of phage but not the other, and vice versa. Such indicator strains were obtained by culturing a lysed bacterial culture. Apparently not all of the bacteria were lysed and killed, because 'secondary' cultures normally developed, which appeared to be resistant to the original phage but susceptible to certain other bacteriophages. The parameters determined by Delbrück and Luria with the one-step growth technique under mixed infection were the duration of the 'constant period', the duration of the 'rise period' and the 'burst size'. Their results from a multiple infection with phage of one strain were 'in conflict with the idea of a simple growth mechanism, like that of a bacterium in a nutrient medium, on

53. Luria started his radiation experiments during his stay in Paris and the results were published as E. Wollman, F. Holweck and S. Luria, 'Effects of Radiations on Bacteriophage $C_{16}$ '. Nature, 145 (1940), 935-6; F. Holweck. S. Luria and E. Wollman, 'Recherches sur le Mode d'Action des Radiations sur les Bactériophages', Comptes Rendus Hebdomadaires des Séances de l'Académie des Sciences, 210 (1940), 639-42 and 799. See also S. E. Luria, A Slot Machine, A Broken Test Tube: An Autobiography (New York, 1984), pp. 64-70. 
the basis of which one would expect a shortening of the latent period in multiple infection'. Therefore, the reproduction of bacterial viruses could not be an autocatalytic process like the multiplication of a bacterium in a suitable medium. They observed that in a mixed infection with two different phages, only one was produced, while the other was completely repressed. The hypothesis that they thought was rejected by their interference experiments was that bacteriophage multiplied in the bacterium until a maximum of phage particles had been produced, after which the bacterial cell lysed. They suggested that the interference phenomenon could have been caused by the dependence of phage growth on a 'key enzyme' which was only available in the cell in limited quantities. In their second report, they observed that in mixed infections phage inactivated by ultraviolet radiation interfered with the growth of another virus acting upon the same host. This again supported the hypothesis of the 'key enzyme'.54

The interference experiments caused the first cracks in Delbrück's presuppositions. Briefly, he supposed phage to be a virus, a category of biological organisms that formed the most simple example of biological multiplication, i.e. a process whereby genes were reproduced. Furthermore, the results of physicochemical studies led him to believe that viruses were probably strictly defined molecules.

Delbrück was to abandon the latter assumption when it was found that bacteriophage could be photographed with the electron microscope and electron micrographs of the bacteriophages showed sperm-like particles. The problem of whether the multiplication of phage took place in the deep interior of the cell or close to the inner surface of the cell wall, could not be solved on the basis of their pictures. The micrographs suggested that most particles remained outside the cell, from which it was concluded that virus particles acted through the cell membrane or that only one particle could enter the cell. Delbrück, Luria and Anderson suggested that the latter hypothesis could also explain the results of their interference experiments. The blocking of the cell membrane after the entrance of one single particle was called the 'penetration hypothesis' and made the hypothesis of a 'key enzyme', which had been suggested only shortly before, redundant. ${ }^{55}$ Delbrück found the penetration hypothesis very

54. M. Delbrück and S. E. Luria, 'Interference between Bacterial Viruses: I. Interference between Two Bacterial Viruses Acting upon the Same Host, and the Mechanism of Virus Growth', Archives of Biochentistry, 1 (1942), 111-41 (pp. 136-8); S. E. Luria and M. Delbrück, 'Interference between Inactivated Bacterial Virus and Active Virus of the Same Strain and of a Different Strain', idem, 1 (1942), 207-18. Interference is nowadays attributed to a phage-induced change in the bacterial 'envelope'; see E. Fischer, et al. (footnote 6), 168. 
attractive because it also suggested an answer to the question of the specificity of viruses for certain hosts, a phenomenon which, as we have seen, he regarded as fundamental to virus research. After all, the blocking of the bacterial cell membrane after the entrance of a phage particle looked like the fertilization of an egg cell by a sperm cell. After the entrance of a sperm cell the egg membrane is changed to prevent further entrance of other sperm cells. The analogy of phage infection of the bacterial cel] with fertilization suggested that the relationship between bacterium and phage might be similar to that between egg cell and sperm cell..$^{56}$

Significantly, it was concluded from the electron micrographs that the bacteriophage they had been studying was much more complex than could be expected of a molecule. Thus, it was concluded from the interference experiments that the multiplication of bacteriophage could not be thought of as an autocatalytic action of a molecule, while at the same time the electron microscope showed the complexity of the phage. Delbrück et al. stated that although chemically one could speak of a molecule, 'neither its configuration nor even its composition is to be taken as necessarily definite'. The characterization of bacteriophage as a biological entity had to be evaluated once again: "While no harm is done by calling viruses "molecules", such a terminology should not prejudice our views regarding the biological status of the viruses, which has yet to be elucidated.' 57

However, if such an important presupposition of Delbruick was found to be falsified, why did the rejection of the molecular nature of bacteriophage not refute his earlier experiments, and why did he perform later experiments (published in three articles in 1945) in the same way as he did before?58 The answer is that the one-step growth experiments and the application of this principle in interference experiments studied bacteriophage as an infectious entity, which meant that the hypothesis concerning the nature of phage was irrelevant. Although Delbrück was concerned to know more about the relationship between phage multiplication and bacterial

55. S. E. Luria, M. Delbrück and T. F. Anderson, 'Electron Microscope Studies of Bacterial Viruses', Journal of Bacteriology, 46 (1943), 57-77. Cf. T. F. Anderson, 'Electron Microscopy of Phages', in J. Cairns, et al. (footnote S), pp. 63-78.

56. See section 4 and $\mathrm{T}$. Anderson (footnote 55), 69-71.

57. S. Luria, et al. (footnote 55), 64 .

58. M. Delbrïck, 'The Burst Size Distribution in the Growth of Bacterial Viruses (Bacteriophages)', Joumal of Bacteriology, 50 (1945), I31-5; M. Delbrück, 'Effects of Specific Antisera on the Growth of Bacterial Viruses (Bacteriophages)', op. cit., 137-50; M. Delbrück. 'Interference between Bacterial Viruses: III. The Mutual Exclusion Effect and the Depressor Effect', op. cit., 15170. 
metabolism, his experiments treated the bacterial cell as a 'black box'.

In his Harvey Lecture, held in 1946, Delbrück claimed the importance of biochemical experiments. He expressed the dependence of phage multiplication on bacterial metabolism by saying that 'the chain of processes which leads to the lysis of the bacteria is tied to some branch of the bacterial metabolism ...' The use of the onestep growth technique for the study of the influence of substrates and metabolic inhibitors constituted 'one of the most promising lines of attack'. 59 In his article in Biological Reviews Delbrück discussed under the heading 'Biochemical Studies of Virus Multiplication', some work done by Emory Ellis and John Spizizen from 1940 and three publications by Spizizen from 1943.60 However, because Delbrück had found that a change in the culture medium influenced the metabolism of the bacteria but was without influence on the minimum 'latent period' of bacteriophage, he thought that the biochemical processes of phage multiplication had a certain autonomy. ${ }^{61}$ In the mid-1940s, Seymour Cohen was to object forcefully to this presupposition. His criticism highlights the implicit assumptions of Delbrïck's research.

Seymour Cohen studied the biochemistry of phage multiplication using the onestep growth technique. Metabolites that were present in the media were monitored and host cells were found to be variable elements that depended on environmental conditions. As Cohen would write later, Delbrück, by contrast, 'treated a bacterium as a sealed container into which a virus had been inserted and from which virus progeny had emerged'. If the bacterium is regarded as such a sealed container, then indeed all one can do is to check the 'input' virus (the parent virus) and analyse phage progeny. ${ }^{62}$

59. M. Delbrück, 'Experiments with Bacterial Viruses (Bacteriophages) [Lecture delivered on 17 January 1946.]', Harvey Lectures, 41 (1946), 161-87 (pp. 171-2).

60. E. L. Ellis and J. Spizizen, 'Glycine - An Essential Factor for the Growth of Bacteriophage', Science, 92 (1940), 91; J. Spizizen, 'Biochemical Studies on the Phenomenon of Virus Reproduction: I. Amino Acids and the Multiplication of Bacteriophage', Journal of Infectious Diseases, 73 (1943), 212-21; J. Spizizen, 'Biochemical Studies on the Phenomenon of Virus Reproduction: II. Studies of the Influence of Compounds of Metabolic Significance on the Multiplication of Bacteriophage', op. cit, 222-8; J. Spizizen, 'Some Preliminary Studies on the Mechanism of Virus Multiplication', Proceedings of the National Academy of Sciences, 29 (1943), 109-14. See M. Delbrück, 'Bacterial Viruses or Bacteriophages', Biological Reviews, 21 (1946), 30-40.

61. M. Delbrück (footnote 51); M. Delbriuck (footnote 59), 17I-2; M. Delbrück (footnote 60), 37-8. Robert Olby compared Delbrück's ambivalent feelings towards biochemistry with the love/hate relationship between the young Max and his father. See R. Olby, 'From Physics to Biophysics', History and Philosophy of the Life Sciences, 11 (1989), 305-9. 
Hence, Delbrück and Luria's interference experiments can be seen as input/output experiments, with the output being analysed, by means of indicator strains, as bacteriophage with a specific host range. ${ }^{63}$ As a result of a finding by Alfred Hershey the research by Max Delbrück gained a new dimension: bacteriophages were not quantified by means of indicator strains but by 'genetic markers'. Hershey had found that the phage strains T2, T4 and T6 of E. coli each showed two modifications, both of which were inheritably stable under most circumstances. These two modifications of the bacteriophages, designated for the T2 phage as T2r+ (wild-type) and $\mathrm{T} 2 r$ (mutant), each produced a type of plaque with typical appearances. ${ }^{64}$ After the discovery of such mutations by Hershey, Delbrïk went on to use such bacteriophages in interference experiments. In these experiments the interference of virus multiplication was again observed and described as the 'exclusion effect' and the 'depressor effect'. There was also a new phenomenon, which involved the genesis of bacteriophage with a new combination of properties and which was designated by Delbrück as induced mutation. He also suggested, however, that the development of a phage with this new combination of properties could be the result of a transfer or exchange of genetic material between the different phages. 65 These findings from the

62. S. S. Cohen, Virus-Induced Enzymes (New York, 1968), pp. 6-7. For a more detailed discussion of the work of Seymour Cohen see Chapter 6 of the present study.

63. The interference experiments used 'indicator strains' which were, for instance, susceptible to bacteriophage alpha but not to bacteriophage gamma. This specific susceptibility of the bacteria was hereditary and the origin of such insusceptible bacterial strains was analysed in a 1943 article by Luria and Delbruick. They concluded that phage-resistant bacteria originated by a mutation of susceptible cells and that the occurrence of resistant bacteria was independent of the presence and action of the bacterial virus. The experiments were performed by Luria while Delbriick worked out the mathematical theory. The experimental technique became known as the fluctuation test. See S. E. Luria and $\mathbf{M}$. Delbrück, 'Mutations of Bacteria from Virus Sensitivity to Virus Resistance', Genetics, 28 (1943), 491-511. The importance of the fluctuation experiment for the emergence of bacterial genetics is emphasized in, e.g. G. Stent (footnote 48), 39; W. Hayes (1984) (footnote 41), 651; T. Brock (footnote 46), 58-63.

64. A. D. Hershey, 'Mutation of Bacteriophage with Respect to Type of Plaque', Genetics, 31 (1946), 620-40; A. D. Hershey, 'Spontaneous Mutations in Bacterial Viruses', Cold Spring Harbor Symposia on Quantitative Biology, 11 (1946), 67-77. The activity of bacteriophage with respect to a certain bacterial indicator strain (its host range) could also be used as a genetic marker. Therefore, Delbrück and Luria's interference experiments from 1942 can be conceived as genetic experiments. N.B.: In bacteriophage the superscript plus sign refers to the wild type of the virus, while in bacteria the superscript plus sign denotes the presence of the property in question $\left(e .8 ., \mathrm{LaC}^{+}\right.$refers to a bacterium able to ferment lactose); see G. Stent (footnote 48), 178. 
mid-1940s were to be fundamental in the emergence of bacterial genetics. 66

Delbruick had had high expectations of his interference experiments in revealing the biochemical process by which phage progeny was produced. ${ }^{67}$ However, his own research led to results at a genetic level which were a direct consequence of his treatment of the bacterial cell as a 'sealed container' or 'black box'. According Seymour Cohen, Delbrück's analysis of input virus and output virus was the key experiment of phage genetics. ${ }^{68}$

After having analysed and characterized the investigations of Delbrück and Northrop, we can now turn to the controversy between these two scientists. As will be argued, they represented the vehicles for the controversy, but the clash was in fact between different contexts or research styles. Delbrück studied bacteriophage as an infectious entity, to be marked and quantified with genetic labels. Northrop studied the formation of bacteriophage as a prototype of protein synthesis. These different approaches resulted in local incommensurability.

\subsection{NORTHROP AND KRUEGER VERSUS DELBRÜCK IN THE EARLY 1940s}

As we have seen, the models developed by Krueger and Northrop on the one hand and by Delbrück on the other differed substantially with regard to the formation of bacteriophage and the role of bacterial lysis in this respect. In Krueger and Northrop's model, the growth of both bacteria and bacteriophage particles took place in a mixture of bacterium/phage, until a limiting ratio of $\mathrm{P} / \mathrm{B}$ was reached (e.g. a ratio of 125 in staphylococcus). According to Delbrück's model, bacteriophage multiplied in or on the bacterial cell until the number of phage particles reached the 'burst size' and the bacterium lysed, liberating phages which could then infect other bacteria. In the end, the model elaborated by Delbrück was to enter the textbooks of molecular genetics and virology. 69

65. M. Delbrück and W. T. Bailey, Jr., 'Induced Mutations in Bacterial Viruses', Cold Spring Harbor Symposia on Quantitative Biology, 11 (1946), 33-7. Cf. M. Delbrück (footnote 59). As was stated in a commemmorative article on Delbrück, the term 'induced mutation' shows how cautious one was in the mid-1940s of thinking in terms of Mendelian crossings. See U. Winkler (footnote 41), 256.

66. T. Brock (footnote 46), 131-7.

67. Although Delbrück expected that the interference phenomenon would elucidate the multiplication of bacteriophage, it is hardly mentioned in textbooks of bacterial genetics and physiology. See E. Fischer, et al. (footnote 6), 168.

68. S. Cohen (footnote 62), 7. 
Why were Delbrück's experimental results not convincing to Northrop and Krueger? For an answer we have to look at the Duhem-Quine thesis, which holds that an experiment does not test only one theory but a whole array of related theories, presuppositions, experiments, and so on.

When Ellis and Delbrück published their one-step growth experiment, Northrop and Krueger were established authorities in the field of phage research. The former concluded that their model did not fit the model for phage formation by Krueger and Northrop, but also that this could have been caused by their working with different species of bacteria ( $B$. coli and $S$. aureus, respectively) and bacteriophages. ${ }^{70}$ Shortly after the article on the one-step growth curve of phage appeared, the Journal of General Physiology published Krueger's extensive report on his research of an intracellular phage precursor. Krueger and Scribner concluded that their results were not incompatible with those of Ellis and Delbrück. ${ }^{71}$ In addition, Northrop's work on B. megaterium (in which Northrop used the plaque assay instead of Krueger's activity assay) also discussed the role of bacterial lysis. In this study, which investigated the formation of the extracellular enzyme gelatinase and the formation of phage by bacterial strains of $B$. megaterium, Northrop concluded that it seemed improbable that bacteriophage for $B$. megaterium and $S$. aureus was produced during the lysis of the bacteria. He did, however, consider it possible that $E$. coli (B. coli) used a different process. ${ }^{72}$

The next step was that Delbruick scrutinized the idea of the activity assay using the one-step growth technique and $E$. coli. In his article on the influence of the physiological condition of the bacterium, Delbrück investigated the role of the rate of adsorption of bacteriophage to a bacterium in the process of phage growth. Delbriuck concluded that the 'day-to-day' fluctuations of the activity assay could be caused by the constantly changing physiological condition of the bacterium. Furthermore, Krueger's results with regard to the adsorption of phage to bacteria might be explained by inhomogeneous phage preparations. ${ }^{73}$

69. G. S. Stent and R. Calendar, Molecular Genetics: An Introductory Narrative, 2nd edition (San Francisco, 1978), pp. 301-5; H. Fraenkel-Conrat and P. C. Kimball, Virology (Englewood Cliffs, N.J., 1982), pp. 30-4. There are, however, bacteriophages (e.g. some filamentous phages) in which bacteriophage is secreted by the bacterium without lysis of the latter. See, for instance, E. C. C. Lin, R. Goldstein and M. Syvanen, Bacteria, Plasmids, and Phages: An Introduction to Molecular Biology (Cambridge, Mass., 1984), pp. 193-5.

70. E. Ellis, et al. (footnote 46), 381-2.

71. A. Krueger, et al. (1939) (footnote 39), 715.

72. J. Northrop (footnote 40), 73. 
In the end, Delbrück got the opportunity to work with Krueger's bacterial strain, and he and Edna Cordts could now apply the one-step growth technique to this system. This research resulted in a manuscript that Delbrück submitted to the Journal of General Physiology at the beginning of 1941, under the title of 'A Reinvestigation of Krueger's Bacteriophage'. Northrop, who was one of the editors of this journal, declined several times to publish the paper and its revisions. ${ }^{74}$

According to Delbrück and Cordts, the activity assay was not suitable for distinguishing between phage within the cell and phage in the medium (intracellular and extracellular phage, respectively). Furthermore, they observed differences in the values for the constant period and the burst size for bacteria in the dividing phase and those in the lag phase. Therefore, Delbrück and Cordts argued that the experimental methods to the oxygenated or 'activated' bacteria, which had led Krueger to be convinced of the presence of a precursor, did not point to this conclusion. ${ }^{75}$

Because of the war, Krueger et al. were not in the position to answer the criticism that Delbrück had directed against the activity assay until 1946. The authors recognized that they might have trusted their laboratory technique too much and thus have forgotten about its limitations. They therefore discussed the multiplication of anti-staphylococcus bacteriophage using both the activity assay and the plaque technique. Delbrück's comment that the activity assay depended on the physiological condition of the bacteria was answered by the claim that their titration curves showed no 'great day to day fluctuations'. Furthermore, they concluded that their observations were not invalidated by the fact that they had used longer sample times than those in Delbrück's experiments. Krueger et al. rejected Delbrück's claim that the 'activated' bacteria in their precursor experiments were bacteria that were in the process of division and were therefore liable to faster adsorption of bacteriophage. Krueger et al. admitted that there were various objections to be made to the existence of a precursor, but they contended that it was an attractive working hypothesis nevertheless, supported by certain experimental evidence. ${ }^{76}$

73. M. Delbrück (footnote 47), 637.9.

74. E. Fischer, et al. (footnote 6), 125. Some of the experimental work from this article was published in Delbrück's review of bacterial viruses from 1942. See M. Delbrück (footnote 51), 16-17. The correspondence berween Delbrück and Northrop on this question is filed in the Delbrück archive of the California Institute of Technology. See T. Brock (footnote 46), 122.

75. M. Delbrück (footnote 51), 16-7.

76. A. P. Knueger, E. J. Scribner and B. B. Brown, 'Further Observations on the Mechanism of Phage Action", Journal of General Physiology, 30 (1946), 25-39. This publication addressed in 
Ultimately, the position of Krueger and Northrop was based upon one fundamental principle, i.e. the formation of bacteriophage without lysis of the bacterium. As a justification of this principle, Krueger and Northrop presented two experimental observations: (a) the lysis of bacteria in the presence of an excess of bacteriophage; and (b) the existence of lysogenic bacteria. The idea that experimental observations can be made compatible with more than one theory, as is stated in the Duhem-Quine thesis, is nicely illustrated by the views of Delbrück on these observations. If $P \gg B$ bacterial lysis was interpreted by Delbrück as 'lysis-from-without' and distinguished from 'lysis-from-within', which implied multiplication of bacteriophage. As for lysogeny, Delbriick was to modify his view on this phenomenon during the 1940 s. As we have seen, Delbrück formulated in 1940 a precursor hypothesis with which he sought to explain lysogeny. However, over the years Delbrück would become more and more sceptical about the existence of this phenomenon. In his 1946 review he wrote that 'pseudo' or 'apparent' lysogeny had to be distinguished from 'real' lysogeny. In explaining 'apparent' lysogeny he used a phenomenon that he had studied with Luria in 1943 and described as the 'fluctuation experiment'. Apparent lysogeny would be the result of a mixture of resistant bacteria and bacteriophage, in which an occasional mutation produced a susceptible bacterium, at the expense of which bacteriophage could multiply. He also questioned the existence of 'real' lysogeny: "A reinvestigation of these ["really" lysogenic] strains would be very desirable, particularly regarding the mechanism by which virus is liberated from the cells on which it multiplies.' 77

In the preceding sections we have seen that both Northrop and Delbriick developed their positions into theoretical networks that created specific contexts. Each of these contexts was built up from a specific research problem, the formation of bacteriophage, legitimizing the choice of the research problem, the aims, the methods of quantifying bacteriophage, the guidelines for performing experiments, and the specific explanation of important phenomena (observations) from bacteriophage research. In this case study, the emphasis was on theoretical notions and experiments, and it is therefore more appropriate to speak of Northrop's and Delbrück's respective research styles.

Before we discuss the impact of the findings of this analysis on the relation between experiment and theory, the positions of Northrop and Delbrück with regard to particular Max Delbrück's 'Absorption of Bacteriophage under Various Physiological Conditions of the Host' (footnote 47) and 'Bacterial Viruses (Bacteriophages)' (footnote 51).

77. M. Delbrïick (footnote 60 ), 34 . 
biochemistry will be sketched. It will be shown that both scientists stuck to their respective points of view during the 1940s.

\subsection{NORTHROP, DELBRÜCK, AND BIOCHEMISTRY IN THE LATE 1940s}

In the preceding section we have seen that the activity assay, as used by Krueger, was severely criticized by Delbrück in the early 1940s. Based on this criticism, Delbrück concluded that Northrop and Krueger's adsorption and precursor experiments were artefacts.

His one-step growth experiments led Delbrück to the conclusion that lysis of bacteria took place even before a limit of the P/B-ratio was reached. The lysis of the bacterial culture that was observed in the activity assay was the result of a cascade of lysis of individual cells. Delbrück's criticism did not convince Krueger and Northrop. In the second edition of Crystalline Enzymes, its authors (including Northrop) concluded that the activity assay was a reliable method of quantifying bacteriophage. They concluded that the activity assay (the 'time method') represented a statistical mean in concentrated suspensions. ${ }^{78}$ Furthermore, the activity assay had proved to be successful in the isolation of anti-staphylococcus phage by Northrop. One of Krueger's co-workers, J. Fong, referred in a review of bacteriophages to the verification of Krueger's results with the plaque method. He accepted the results of Krueger's research group in search for a modified form of a phage precursor. Where Krueger had interpreted the experiments as pointing to the existence of a precursor, they were now seen as an observation indicating that 'the working hypothesis whereby formation of phage can result from the use of cellular enzyme systems is sound, although the experimental evidence now available relative to this point is not conclusive ... ${ }^{79}$ [Italics mine.]

In the early 1950 s it was generally accepted that in the case of lysogenic bacteria bacteriophage is also liberated by means of bacterial lysis. Thus, lysogeny was not an artefact as had been surmised by Delbrück. In a review of lysogeny, Lwoff pointed to the danger of 'hypothetical secretions' of bacteria, by which he was doubtlessly referring to the results of Krueger and Northrop. ${ }^{80}$ But the core of Krueger's and Northrop's views on bacteriophage was not only that phage was secreted, but also that there was an important analogy between the formation of some viruses on the one

78. 'Bacteriophage', in J. H. Northrop, M. Kunitz and R. M. Herriott, Crystalline Enzymes, 2nd ed. (New York, 1948), pp. 196-208.

79. J. Fong, 'Bacteriophage', Annual Review of Microbiology, 3 (1949), $423-44$ (p. 442).

80. See 'Danger of Hypothetical Secretions' in A. Lwoff (footnote 20), 330-1. 
hand and proteins in general on the other. Northrop distinguished viruses such as vaccinia, which clearly looked in many ways like bacteria, and the well-defined crystalline viruses like tobacco mosaic virus and bushy stunt virus, which were typical '(nucleo)proteins'. It was only because of their pathological effect that viruses were thought related to parasites. Northrop thought that bacteriophage belonged to the welldefined virus protein molecules (nucleoproteins). The correlation between the metabolism of the bacterial cell and the formation of bacteriophage made Northrop conclude that 'the synthetic part of the reaction [the production of bacteriophage] is carried out by the cell in conjunction with the synthesis of normal proteins, since the viruses themselves do not contain the enzymes necessary to carry out these reactions', 81

Northrop positioned the problem of the formation of bacteriophage at the center of the research problem of protein synthesis. In the latter case he distinguished two types of reactions, namely, those in which no energy was added and those in which this did occur. In catalytic synthesis, where no energy was added, the equilibrium could be shifted into the direction of protein, either by a change in concentration, or because of removal of the protein. As an example, Northrop mentioned the creation of protein surface films. ${ }^{82}$ In the second type of reaction, the equilibrium was shifted in the direction of protein by adding energy. This might occur via a reaction coupled to protein synthesis or via the use in the synthesis of building blocks other than amino acids. Northrop assumed that amino acids were coupled via an energy-requiring step to one or more 'type' proteins (in German also called 'Urprotein') that were specific for the species and possibly specific for the organ. These proteins were designated by Northrop as 'proteinogen'. In the next step an individual protein was formed from the proteinogen by a catalytic or autocatalytic reaction that required no energy and could take place anywhere. The proposed mechanism had to explain the group specificity of proteins from one species and organ. It will be no surprise that this mechanism for protein synthesis was based on the formation of enzymes from precursors, which was shown by Northrop's research group to occur in several enzymes. Northrop admitted that his working hypothesis could be falsified but he maintained that if the hypothesis leads to the discovery of new facts it will have served its purpose even though the new

81. 'Furmation of Viruses', in J. Northrop, et al (footnote 78), pp. $238-42$ (p. 239). Cf. J. H. Northrop, 'Enzymes and the Synthesis of Proteins', in The Chemistry and Physiology of Growth, edited by A. K. Parpart (Princeton. New Jersey, 1949), pp. 3-48.

82. J. Northrop (1949) (footnote 81), 7. Cf. I. Langmuir and V. J. Schaefer, 'Activities of Urease and Pepsin Monolayers', Joumal of the American Chemical Societ), 60 (1938), 1351-60. 
facts destroy the assumptions which led to their discovery" 83

For Northrop autocatalysis was the only known chemical synthesis reaction for which it was not necessary to assume the presence of other substances whose existence was unproven. Since he liked to use Occam's razor, he assigned to autocatalysis a central role in the synthesis of protein. ${ }^{84}$

This was the context that Northrop outlined for his discussion of the synthesis of bacteriophage. He stated that no experimental evidence was available to distinguish the formation of virus from that of normal protein. Both took place only in or on living cells and the only difference was that

\begin{abstract}
'normal' proteins are always produced by the cells but that the production of some virus protein may be started by introduction of the protein from outside the organism. Phage produced by lysogenic strains of bacteria and 'indigenous virus' of plants and animals are always produced just as are 'normal' proteins. It can, of course, be assumed that infection occurred sometime in the past, but there is no direct evidence for this assumption. No means is known to free lysogenic strains from their viruses. ${ }^{85}$
\end{abstract}

In line with these basic assumptions, Northrop continued the study of the problem of protein synthesis with a biochemically oriented study of lysogeny. From this he concluded that infected cells could grow in a culture of lysogenic $B$. megaterium and that the potential capacity to produce phage was passed on to its daughter cells, an observation that he saw confirmed in the work of André Lwoff and Antoinette Gutmann (1950). Again Northrop referred to the possible involvement of an autocatalytic process; he stated that the 'nucleic acid may be the essential, autocatalytic part of the molecule, as in the case of the transforming principle of the pneumococcus,

83. J. Northrop (1949) (footnote 81), 16.

84. Cf. J. H. Northrop, 'Biochemists, Biologists, and William of Occam', Annual Review of Biochemistry, 30 (1961), 1-10. Northrop referted to a number of papers from the long tradition of explaining biological and chemical 'growth' with the help of autocatalysis, inciuding L. Troland (footnote 30); N. K. Koltzoff, 'Physikalisch-chemische Grundlage der Morphologie', Biologisches Zentralblatt, 48 (1928), 345-69; J. Northrop. 'The Formation of Enzymes' (footnote 37); A. Gulick, 'What are the Genes?: II. The Physico-Chemical Picture; Conclusions', Quarterly Review of Biology, 13 (1938), 140-68; I. Langmuir, et al. (footnote 82); W. Stanley (1938) (footnote 33); L. Pauling, 'A Theory of the Structure and Process of Formation of Antibodies', Journal of the American Chemical Sociefy, 62 (1940), 2643-57; C. D. Darlington, 'Heredity, Development and Infection', Nature, 154 (1944), 164-9; P. Jordan, 'Zum Problem der EiweiB-Autokatalysen', Naturwissenschaften, 32 (1944), 20-6.

85. J. Northrop (1949) (footnote 81), 22-3. 
and the protein portion may be necessary only to allow entrance to the host cell'. 86

Northrop's work on the problem of protein synthesis was characterized by its use of the most simple hypothesis that appeared compatible with his experimental results. It has already been shown that for Delbrück too, the problem of the synthesis of virus material was one of the main problems of bacteriophage research, next to the way in which accurate reproduction occurred. Because of the simplicity of viruses and especially bacterial viruses, this problem did not appear so difficult to him. ${ }^{87}$ The results of his research made it perfectly clear that this presupposition was a mistake. In sharp contrast to electron micrographs of plant viruses, bacteriophages appeared to be complex particles. The former viruses appeared to consist of regular rods and balls, which corroborated the physicochemical behaviour which had been determined with other methods. Not surprisingly, Mark Adams, a member of the 'Phage Group', concluded in 1950 that bacterial viruses seemed to have more similarity with animal viruses than with plant viruses: 'It is now generally agreed that the bacteriophage principle of d'Hérelle is a group of filtrable viruses, parasitic on bacteria and more closely related chemically and physically to the animal viruses than to the plant viruses. 88 [Italics mine.] For those who are familiar with the present definition of viruses, formulated in 1957 by André Lwoff, it will be clear that, conceptually, Adams's distinction in defining viruses can no longer be regarded as valid. ${ }^{89}$

The interference experiments with 'genetically labeled' bacteriophages led to the conclusion that bacterial viruses underwent the same complex phenomena as the cells of higher organisms. As was stated by Max Delbrück in 1949, the use of bacteriophage as a simple model for the replication of genes had to be rejected:

86. J. H. Northrop, 'Growth and Phage Production of Lysogenic B. Megatherium', Journal of General Physiology, 34 (1951), 715-35 (p. 732). Cf. A. Lwoff and A. Gutmann, 'Recherches sur un Bacillus Megatherium Lysogène', Annales de l'Institut Pasteur, 78 (1950), 711-39; translated as 'Investigations on a Lysogenic Bacillus Megaterium', in Papers on Bacterial Viruses, edited by G. Stent, (Boston, 1960), pp. 312-31.

87. M. Delbrück (footnote 59), 162.

88. M. H. Adams (ed.), 'Methods of Study of Bacterial Viruses', Methods in Medical Research, 2 (1950), $1-73$ (p. 1).

89. In 1957 André Lwoff defined viruses as 'infectious, potentially pathogenic, nucleoproteinic entities possessing only one type of nucleic acid, which are reproduced from their genetic material, are unable to grow and to undergo binary fission, and are devoid of a Lipmann system.' See A. Lwoff, 'The Concept of Virus: The Third Marjory Stephenson Memorial Lecture', Journal of General Microbiology, 17 (1957), 239-53 (p. 246). Cf. footnote 7 of Chapter 1 of the present study. 
At first sight this [the reproduction of a virus particle] may seem simpler than cellular reproduction because the individual virus particle is a very much smaller unit than the individual cell and may be analogous to an individual gene or to a small group of genes. In some respects, however, this case is really more complex than that of the reproduction of a cell. (...) [T] he complexities of sexual reproduction and of recombination are not eliminated by going to this seemingly elementary level. (...) [T] The virus particles themselves are complex, and that their reproduction must involve manoeuvers analogous to those occurring in meiosis and conjugation of higher organisms. This is news that is exciting principally by the blow it deals to our fond hope of analyzing a simple situation..$^{90}$

In fact the phage experiments with genetic markers along the lines indicated by Delbrück and Hershey (performed in accordance with the one-step growth technique) did not differ from the crossing experiments which had proved so successful in Drosophila. ${ }^{91}$ It is important to note that, in contrast to those in biochemical research, these experiments involved observations at the level of the genotype and phenotype, while no molecular explanations were offered. To emphasize this important point it is useful to quote the biochemist Earl A. Evans, Ir, who worked along the methodological lines of the 'Phage Group':

The contributions of the chemist to the rapidly developing understanding of this process [the mechanism of viral reproduction] must necessarily lag behind the more dexterous explorations of the microbiologist and geneticist, but they have the virtue of carrying the description, even though incomplete, to the ultimate molecular level. ${ }^{92}$

Northrop's aim to give a materialistic or molecular explanation for the processes of life urged him to formulate in the 1930s and 1940s a working hypothesis which could explain the processes of life at a molecular level. ${ }^{93}$ Although Delbrück was rather hopeful about the contributions to be expected from biochemistry in his review of

90. M. Delbrück, 'A Physicist Looks at Biology', Transactions of The Connecticut Academy of Arts and Sciences, 38 (1949), 173-90; reprinted in J. Cairns, et al. (footnote 5), pp. 9-22 (pp. 13-4).

91. A. H. Sturtevant, A History of Genetics (New York, 1965); E. A. Carlson, The Gene: A Critical History (Philadelphia, 1966); L. C. Dunn, A Short History of Genetics - The Development of Some of the Main Lines of Thought: 1864-1939 (Ames, 1965, repr. 1991).

92. E. A. Evans, Jr, 'The Biochemistry of the Bacterial Viruses', in Essays in Biochemistry, edited by S. Graff (New York, 1956), pp. 94-105 (p. 94). For a discussion of the research of biochemists on bacteriophage see Chapter 6 of the present study.

93. Cf. W. Seifriz, 'A Materialistic Interpretation of Life', Philosophy of Science, 6 (1939), 266-84. This essay was markedly influenced by Northrop's views on the study of living processes. 
bacterial viruses in 1946, some years later he was much more pessimistic. In his lecture to the Connecticut Academy of Arts and Sciences in 1949, he showed serious doubts about what could be expected from biochemistry. The problem with which biochemistry was confronted in relation to the formation of bacteriophage was the question 'how the virus particle manages to shunt the utilization of assimilatory products into its own channels ...' But to Delbrück it was not clear at all how biochemical studies with, for instance, radioactive isotopes could provide clues about the chemical mechanism of replication:

Listening to the story of modern biochemistry he [a physicist] might become persuaded that the cell is a sack full of enzymes acting on substrates converting them through various intermediate stages either into cell substance or into waste products. The enzymes must be situated in their proper strategic positions to perform their duties in a well regulated fashion. They in turn must be synthesized and must be brought into position by manoeuvers which are not yet understood, but which, at first sight at least, do not necessarily seem to differ in nature from the rest of biochemistry. Indeed, the vista of the biochemist is one with an infinite horizon. And yet, this program of explaining the simple through the complex smacks suspiciously of the program of explaining atoms in terms of complex mechanical models. It looks sane until the paradoxes crop up and come into sharper focus. ${ }^{94}$

It is especially through Delbrück's low opinion of the contributions of biochemistry that this discipline was to be underrated in the historiography of molecular biology. 95

\subsection{CONCLUSION: CLASHING RESEARCH STYLES}

In the 1950s and 1960s researchers of Delbrück's 'Phage Group', as well as other geneticists and biochemists, were to be very successful, which greatly contributed to the establishment of molecular biology and bacterial genetics. In the historiography of these disciplines the work of Krueger and Northrop, and especially the activity assay and the 'precursor theory', would be heavily criticized. In particular, John $H$. Northrop's reputation as biochemist confronts us with the problem why Delbrück's 'clear-cut' experiments did not change Northrop's opinion of the role of lysis in the

94. M. Delbrück (footnote 90 ), 14 and 22, respectively.

95. S. S. Cohen, 'The Biochemical Origins of Molecular Biology: Introduction', Trends in Biochemical Sciences, 9 (1984), 334-6; S. S. Cohen, 'Finally, the Beginnings of Molecular Biology', idem, 11 (1986), 92-3; R. Olby, 'Biochemical Origins of Molecular Biology: A Discussion', idem, 11 (1986), 303-5. 
formation of bacteriophage. This can be understood if the controversy between Northrop and Delbruick is not interpreted as a debate to decide which of two hypotheses on the formation of bacteriophage and the role of bacterial lysis was correct. The discussion on the activity assay, the precursor theory and the one-step growth technique was a clash between research styles. Delbrück's criticism of the activity assay was countered with a whole complex of presuppositions, research problems, experimental models, experiments, hypotheses, and so on. The two contexts that clashed here were Northrop's physiological/chemical research style and Delbruick's bacteriological/genetic research style. Within the first, bacteriophage was regarded as dependent on the metabolism of the bacterial cell and thus as a product of bacterial synthesis. By contrast, Delbrück's style conceived of bacteriophage as an independent entity and therefore the formation of phage as autonomous multiplication.

These two styles were each anchored in networks of 'similarities' and 'dissimilarities'. Northrop studied bacteriophage, and especially lysogenic bacteria, because he saw similarities between the formation of phage and that of normal protein, (adaptive) enzymes, and antibodies. It was from this point of view that he quantified bacteriophage, expressed its formation in mathematical formulae, strived at its isolation, and tackled the problem of protein synthesis. To Delbrück, bacteriophage was a model for viruses and genes, and his research can be characterized as the study of the multiplication of bacteriophage at the level of the end product, i.e. complete phage particles. This approach revealed itself in the technique with which he quantified bacteriophage, analysed virus multiplication, and characterized bacteriophages (genetic properties, e.g. plaque morphology and 'host range'). Each research style had its own conceptual network, as was apparent from the different interpretations of the research on plant viruses using physicochemical techniques (e.g. that of Wendell Stanley). That plant viruses consisted of (nucleo)proteins was for Northrop a proof that such viruses (and not the more complex animal viruses) formed a specific case of protein synthesis. To Delbrück the characterization of plant viruses highlighted the question of the mechanism by which the molecular composition of viruses (i.e., bacterial, plant and animal viruses) was reproduced.

At the end of the 1930s, Max Delbrück was a newcomer in the field of bacteriophage research. When the experimental technique he developed with Emory Ellis was applied to $E$. coli, the resulting picture differed from that formulated by Northrop and Krueger from the model of the staphylococcus, using the 'time-method'. Perhaps it is typical of Delbrück's character that he saw in this an opportunity to criticize such a 
renowned scientist as Northrop, who was affiliated with the Rockefeller Institute. Delbrück might also have concentrated on his $E$. coli model and have left the $S$. aureus model for what it was. From his experience with $E$. coli he came to the general belief that bacteriophages were liberated by lysis of the bacterial cell, as a consequence of which he questioned the mechanism proposed by Krueger and Northrop and the existence of lysogenic bacteria.

In the early 1940s, Delbrück assumed that bacteriophages could be characterized as simple, well-defined molecules that might grow by a process of autocatalysis. The results of his interference experiments threw this into doubt and he and Luria suggested that the observed interference might be explained by a 'key enzyme'. From the electron micrographs that became available in 1943 they concluded that bacteriophage was apparently more complex than the 'molecular' plant viruses. 96 One important conclusion of the analysis of Delbrick's research programme is that the falsification of this presupposition had no consequences for Delbrück's experiments, because this programme studied phage at the level of the infectious particle. In a later phase of the phage research the bacteriophage would again be defined as a molecule, i.e. a chain of nucleotides that carried the genetic information.

Gunther Stent would later write that several of the conclusions of the experiments of the 'Phage Group' in the 1940s and early 1950s would prove to be mistaken in the end:

[T] hough the immediate conclusions drawn from the results of the experiments of the romantic phase were almost always right, the more general and really interesting speculations built upon these first-order conclusions were mostly wrong. (...) [W] see that such ideas as the bacterial 'key enzyme' for which infecting viruses were supposed to compete, the multiplication of the viral genome by independent subunits, genetic recombination in phage by 'partial replicas' or 'copy choice,' and bacterial recombination by cell fusion and postzygotic elimination of genetic material did not stand the test of time. The last mistaken idea to be produced in the romantic phase, based not unreasonably on the finding of proteinaceous, DNA-free phage precursors during the eclipse period of phage growth, was that protein is the viral genetic material. ${ }^{97}$

96. Furthermore, they concluded from these photographs that it was now proven that Krueger's precursor did not exist. See S. E. Luria, et al. (footnote 55), 65. Cf. T. Anderson (footnote 55). It is to be noted that Northrop and Krueger had always stated that it was not certain whether phage was produced by a hydrolytic cleavage of a preforned protein precursor (as was the case with, for instance, the autocatalytic transformation of trypsinogen) or whether it involved the completion of a complex protein synthesis by the cell under the stimulus of contact with phage.

97. G. Stent (footnote 5), 393. 
Northrop's precursor hypothesis of protein synthesis was not to be incorporated into textbooks, as Northrop had already anticipated himself as a possibility. His claim that phage production is simply a special case of protein synthesis was, in a strict sense, not confirmed either. However, the formation of bacteriophage can be seen as a specific case of the synthesis of nucleoproteins. The synthesis of proteins would eventually be explained as a genetically regulated system. 98

98. P. N. Campbell and T. S. Work, 'Biosynthesis of Proteins', Nature, 171 (1953), 997 1001 ; F. H. C. Crick, 'On Protein Synthesis', Society of Experimental Biology Symposia, 12 (1958), 138-63; F. Jacob and J. Monod, 'Genetic Regulatory Mechanisms in the Synthesis of Proteins', Joumal of Molecular Biology, 3 (1961), 318-56; 'Gene Expression and Regulation', in T. Brock (footnote 46), 265-324; the literature cited in footnote 31. 
CHAPTER 6

The Construction of Bacteriophage as Bacterial Virus:

Linking Endogenous and Exogenous Thought Styles

CONTENTS

\subsection{Introduction $\mathbf{1 5 2}$}

6.2 Attempts to link exogenous and endogenous thought styles 154

6.3 The 'modern concept of phage' $\mathbf{1 6 2}$

6.4 'Infectious heredity' revisited $\mathbf{1 7 0}$

6.5 Construction of bacteriophage as bacterial virus $\mathbf{1 7 4}$

Second part of an essay to be published in

Journal of the History of Biology, vol. 26 (1993), in press. 
CHAPTER 6

\section{The Construction of Bacteriophage as Bacterial Virus: Linking Endogenous and Exogenous Thought Styles}

\subsection{INTRODUCTION}

In the two last chapters it was argued that in the 1930s and 1940 s two controversies on the nature of bacteriophage developed between conflicting research programmes. In the 1950 s a definition for viruses was proposed which claimed a difference between viruses on the one hand and organisms and cellular constituents with genetic continuity (for instance genes) on the other. In 1957 André Lwoff proposed an explicit definition which encompassed these characteristics and suggested that "viruses are infectious, potentially pathogenic, nucleoproteinic entities possessing only one type of nucleic acid, which are reproduced from their genetic material, are unable to grow and to undergo binary fission, and are devoid of a Lipmann system."' An important basis of this new concept of virus was the growing belief that the genetic information of organisms is encoded in the sequence of the building blocks of nucleic acid. ${ }^{2}$

The importance of this new insight was that fierce controversies over the nature of bacteriophage, which had lasted for several decades, were considered to be "resolved." The power of this "modern concept of virus" to unite various notions of the nature of bacteriophage is evident from the following quotation from Alfred D. Hershey, one of the nestors of the above mentioned "Phage Group." In 1956 he posed the question of the nature of bacteriophage. His answer was that at that moment a bacterial virus or bacteriophage was "a parasitic microbe in ecology, a bacterial organelle during its existence as prophage, a marker on the bacterial chromosome in breeding experiments with lysogenic bacteria, a subgamete for which names are lacking when it transmits lysogeny, a vector of unrelated bacterial organelles,

1. Andre Lwoff, "The Concept of Virus; The Third Marjory Stephenson Memorial Lecture," J. Gen. Microbiol., 17 (1957), 239-253, esp. p. 246. In fact, Lwoff had described this concept of virus as early as 1953 but at that time he was doubtful about the validity of his definition; see Andre Lwoff, "Lysogeny," Bact. Rev., 17 (1953), 269-337, esp. p. 332. For a discussion of the formation of consensus see also Chapter 7 of the present study.

2. Robert Olby, The Path to the Double Helix (London: Macmillan, 1974); Horace F. Judson, The Eighth Day of Creation: Makers of the Revolution in Biology (London: Jonathan Cape, 1979). 
including other prophages, in transduction experiments, and the inciter of an explosive disease of nucleic acid metabolism when it mimics [bacteriophage] T2." 3 When applied to bacteriophage the "modern concept of virus" was able to link the results of such diverging disciplines as epidemiology, cellular biology, genetics and biochemistry. This chapter outlines the dynamics which eventually led to a consensus in the controversies on the nature of bacteriophage.

As was said above, the history of bacteriophage research has been marked by several heated debates. ${ }^{4}$ In this chapter I will argue that these controversies can be traced to a contrast between two thought styles, the one being exogenous and the other endogenous. The exogenous thought style sought an explanation for bacteriophagy by assuming an exogenous agent, for most scientists an autonomous virus. By contrast, the endogenous thought style explained bacteriophagy as a result of the metabolism (physiology) of the bacterium. As was pointed out by Cohen and Schnelle, Ludwik Fleck's conception of a thought style claims that such a style shapes the observations and definitions of "facts" by the individual members of a "thought collective." In this way, restrictions are placed on the choice of relevant scientific problems to be solved and on the methods by which this has to be done. Thus, not only concepts but also the experimental armamentarium is defined by the particular thought style. This chapter will only discuss the "stylistic bonds" between experimental material, experiments and concepts. The sociological dimensions of the thought collectives will not be addressed here, although they are of course important in distinguishing conflicting thought styles. ${ }^{5}$

3. Alfred D. Hershey, "Bacteriophage T2: Parasite or Organelle? [Lecture delivered on 26 April 1956.]," Harvey Lect., 5 I (1957), 229-239, esp. p. 238. Together with Max Delbrück and Salvador E. Luria, Hershey received the Nobel Prize in 1969 for his contributions to bacterial virus research. See Gunther Stent, "The 1969 Nobel Prize for Physiology or Medicine [Max Delbrück, Salvador Luria and Alfred Hershey]," Science, 166 (1969), 479-481. A sociological analysis of the "Phage Group" was presented by Nicholas C. Mullins, "The Development of a Scientific Specialty: The Phage Group and the Origins of Molecular Biology," Minerva, 10 (1972), 51-82.

4. For the history of bacteriophage research see, for instance, Lwoft, "Lysogeny" (above, n. 1); Gunther S. Stent, Molecular Biology of Bacterial Viruses (San Francisco: W. H. Freeman and Co., 1963); Donna H. Duckworth, "Who Discovered Bacteriophage?," Bact. Rev., 40 (1976), 793-802; Alan W. Varley, Living Molecules or Autocatalytic Enzymes: The Controversy over the Nature of Bacteriophage, 1915-1925 (Ph.D. Thesis, University of Kansas, 1986; University Microfilms International, no. 8711282); Charles Galperin, "Le Bactériophage, la Lysogénie et son Déterminisme Génétique," Hist. Phil. Life Sci., 9 (1987), 175-224; Thomas D. Brock, The Emergence of Bacterial Genetics (Cold Spring Harbor, New York: Cold Spring Harbor Laboratory Press, 1990). 
The work of several scientists is discussed who tried to bridge the gap between these positions within the exogenous and endogenous thought styles. This eventually led to the "modern concept of virus." The formation of consensus was the very reason that bacteriophage could be regarded simultaneously as a bacterial virus and as a product of the bacterium; or as a corollary to this point of view, that the exogenous nature of a virus in general was reconciled with the notion of a virus as a product of the host cell. In current virology the question Is bacteriophage a bacterial virus? is answered in the affirmative. The formation of this consensus has to be analyzed by investigating how the different notions were linked in the 1950s and bacteriophage was constructed as a bacterial virus.

However, at the very moment that a definition for viruses was proposed which linked the endogenous and exogenous thought styles, new observations were reported which resulted in the terms exogenous and endogenous losing any meaning in bacteriophage research. Nevertheless, the "modern concept of virus" retained its usefulness for demarcating a domain for scientists who called themselves virologists.

\subsection{ATTEMPTS TO LINK EXOGENOUS AND ENDOGENOUS THOUGHT STYLES}

Each of the research programmes discussed in the two last chapters gave specific interpretations of the nature of bacteriophage, bacteriophagy and the phenomenon of lysogeny. However, the hypotheses on the nature of bacteriophage and bacteriophagy which were expressed in the course of four decades were not limited to these particulars. This section discusses the positions of three researchers with respect to the nature of bacteriophage. They all attempted to bridge the gap between the exogenous and endogenous thought styles. ${ }^{6}$ In the context of this essay the relevance of these

5. Robert S. Cohen and Thomas Schnelle, "Introduction," in idem, eds, Cognition and Fact: Material on Ludwik Fleck, (Dordrecht: D. Reidel, 1986), pp. ix-xxxiii. On the concepts of thought style and thought collective see also Ludwik Fleck, Genesis and Development of a Scientific Fact, ed. Thaddeus J. Trenn and Robert K. Merton (Chicago: University of Chicago Press, 1979). $C f$. Chapters I and 7 of the present study.

6. The various hypotheses on the nature of bacteriophage which were proposed up to the mid 1950s, could be divided into the following categories (in brackets a prominent defender of the position): ferment theory (Kabéshima), virus theory (Félix d'Hérelle), bacterial antagonism (Paul Hauduroy, Jules Bordet), bacteriolytes (E. Plantureux), bacterial autolysis (Jules Bordet), hereditary factors (Eugène and Elisabeth Wollman), gene theory (Otto Rahn), "Pettenkoferien" (Ph. Kuhn), "splitter" theory (Oskar Bail). See Hansjürgen Raettig, Bakteriophagie 1917 bis 1956. Teil I: Einfihrung, Sachregister, Stichwortverzeichnis (Stuttgart: Gustav Fischer Verlag, 1958), pp. 141- 
examples is not only in the contributions these researchers made to the formation of consensus between these thought styles but also in the fact that their work validates the very existence of the two thought styles.

\section{Evolutionary considerations}

The Australian bacteriologist and later immunologist Macfarlane Bumet studied phages from a biological point of view. Burnet's interpretation of their nature was largely based on the work of William J. Elford and Christopher $H$. Andrewes on the sizes of various strains of bacteriophages. By using collodion membranes with graded permeability for particles, the latter researchers concluded from the regularity of their bacteriophage filtration curves that phage particles of a particular pure phage were uniform in size. However, the sizes of bacteriophages of different pure strains showed a whole range of diameters. ${ }^{7}$ From these experiences Macfarlane Burnet concluded that phage particles were certainly organized and had to be considered as viruses of bacteria. Although Burnet's position showed a certain similarity to d'Hérelle's viewpoint, important differences can also be noted. Bumet attached great value to the gradations in "pathogenicity" between various strains of phages which were manifest in the phenomenon of lysogeny. ${ }^{8}$ It should be recalled that d'Herelle considered lysogeny as a bacteriological contamination of a bacterium with bacteriophage.

Macfarlane Burnet argued that the importance of lysogeny could be evaluated by asking whether every bacterium was lysogenic. The property of being lysogenic could be established by culturing the bacterium in the presence of a suitable bacterial indicator strain, lysogeny being made visible by lysis of this strain. Burnet concluded that the question whether every bacterium was lysogenic could not be answered in this way because a negative answer to the test could also be caused by the unsuitability of the indicator strain. But one could investigate how wide-spread lysogeny was in nature. Using three highly susceptible bacterial cultures as indicator strains, Burnet investigated a great number of salmonella cultures for lysogenicity. Somewhat surprisingly, lysogeny was found with remarkable high frequency being present in 93

7. William J. Elford and Christopher H. Andrewes, "The Sizes of Different Bacteriophages," Brit. J. Exp. Path., 13 (1932), 446-456; reprinted in Nicholas Hahon, ed., Selected Papers on Virology (Englewood Cliffs, New Jersey: Prentice-Hall, 1964), pp. 163-170.

8. F. Macfarlane Burnet, "Recent Work on the Biological Nature of Bacteriophages," Trans. Roy. Soc. Trop. Med. Hyg. 26 (1933), 409-416; idem, "The Bacteriophages," Biol. Rev., 9 (1934), 332-350. 
of 131 strains tested. It was concluded that lysogeny should be considered as a normal function of the bacterium. ${ }^{9}$

But Burnet also observed that bacterial cultures of one single strain, like the lysogenic salmonella strains $B$. enteridis and $B$. paratyphosus, could yield bacteriophages of different strains. The differences between such phages were shown, for instance, by means of immunological techniques. Bacteriophage obtained from these bacterial strains was independent of the nature of the organism from which it was isolated. Burnet claimed that this observation could only be explained by assuming that the evolutionary development of bacteria and bacteriophages had essentially been independent. The phenomenon of lysogeny constituted an important argument for Burnet's conclusion that "bacteriophages form a group of independently evolved living organisms capable of entering into parasitic or symbiotic relationships with bacteria." 10

In an earlier paper, with Margot McKie as co-author, Burnet had shown that when a certain lysogenic strain of $B$. enteritidis was cultured on different types of substrate, this could result in a whole series of bacterial variants: smooth and rough, motile and non-motile, mucoid and pellicle-forming bacteria. It was remarkable that when these variants were cultured in broth, they all produced the same bacteriophage. Because of the permanence of the lysogenic character Burnet and McKie concluded that it was plausible "to assume the presence of bacteriophage or its anlage [capacity] in every cell of the culture, i.e., it is part of the hereditary constitution of the strain." " [Italics in the original.] They concluded that a dualistic concept of the nature of bacteriophage was possible. Depending on the type of bacterium reacting with a particular phage, it might be useful "to regard the phage as an independent parasite or as a unit liberated from the hereditary constitution of some bacterium, the usage being determined wholly by its functional activity at the time." 12 The idea of bacteriophage being a hereditary element originating from the bacterium was an important position within the endogenous thought style.

9. F. Macfarlane Burnet, "Lysogenicity as a Normal Function of Certain Salmonella Strains," J. Path. Bact., 35 (1932), 851-863.

10. Burnet, "Recent Work" (above, n. 8), p. 413. Cf. idem, "The Bacteriophages" (above, n. 8).

11. F. Macfarlane Burnet and Margot McKie, "Observations on a Permanently Lysogenic Strain of B. Enteritidis Gaertner," Austr. J. Exp. Biol. Med. Sci., 6 (1929), 277-284, esp. p. 282; reprinted in Hahon, Papers (above, n. 7), pp. 115-123, esp. p. 121.

12. Burnet and McKie, "Observations" (above, n. 11), p. 284; reprinted in Hahon, Papers (above. n. 7), pp. 115-123, esp. p. 123. 
This position was strongly supported by research on lysogenic spore-farming bacteria which had shown that when a lysogenic bacterim went through the spore

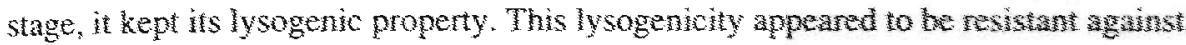
any temperature which left the spore alve, evan hough free bacterophage was inactivated by such temperatures, 1 On the basis of this type of researct and that w lysogeny in general, Burnet thought it understandable that most of those who studied these phenomena preferred the notion that the "liberated phage is not an monomous micro-organism but some unit of the bacterial "chromatin, a vagrant gene freed from normal constraint." The work of Eugène and Elisabeth Wolman su an example of such genetically oriented research.

\section{Bacterid hereditary factors}

For Eugène and Elisabeth Wollman too, the question of the nature of bacteriophage was asked against the background of the contrast between an exogenous and an endogenous interpretation, that is to say, the position which interpteted bacteriophage as a living parasite versus the notion which conceived of it as a product of the bacterium. In 1935 Eugène Wollman reviewed the criticism to which these wo theories (the "parasitic theory" versus the "diastatic theory") had been exposed in the 1930 s. According to Wollman the most serious criticism of the parasitic theory came from those who had studied spontaneously lysogenic bacteria, e.g., Macfarlane Burnet. Furthermore, Jules Bordet had argued that when calcium was removed from the culture medium, spontaneously jysogenic $B$. coli showed neither lysis of susceptible bacteria nor regeneration of the active lytic principle. However, when the bacterium was transferred to normal medium, the lytic principle was again produced. Similar results were obtained by Wollman with spontaneously lysogenic bacterial cultures of B. megaterium. ${ }^{15}$ Another finding which was regarded by Eugène Wollman as

13. Louis E. den Dooren de Jong, "Studien über Bakteriophagie. I. Mitteilung: Über Bac. Megatherium und den darin anwesenden Bakteriophagen," Zentralbl. Bakt. Parasitenk. Injekt., I. Abt., Orig., 120 (1931), 1-15; idem, "Studien über Bakteriophagie. II. Mitteilung: Fortsetzung der Untersuchungen über den Megatherium-Bakteriophagen," idem, 120 (1931), 15-23; Philip B. Cowles, "The Recovery of Bacteriophage from Filtrates Derived from Heated Spore-Suspensions," $J$. Bact., 22 (1931), 119-123. It was soon argued, however, that this observation could also be explained by the assumption that dried bacteriophage is more resistent to heat than its hydrated form. The preservation of the phage-producing property of lysogenic bacteria could then be explained by the assumption that phage in a bacterial spore is heat-resistent because of its presence in dehydrated form. See Aron Vedder, "Die Hitzeresistenz von getrockneten Bakteriophagen," idem, 125 (1932), 111-114.

14. Burnet, "The Bacteriophages" (above, n. 8), p. 346. 
contradictory to the parasitic theory was his observation that when the $B$. megaterium strain studied by Louis den Dooren de Jong was cultured on a gelose nutrient, no bacteriophage was found. However, when such a culture was lysed with lysozyme, bacteriophage was produced and it could be shown that each bacterium liberated one bacteriophage particle. ${ }^{16}$

According to Eugène Wollman, the defenders of the diastatic theory claimed that bacteriophagy was the result of soluble substances, lytic ferments, lysines or autolysines. However, his own research had led Wollman to conclude that one had to distinguish between the bacteriophage, which does not show any lytic action itself, and a bacterial autolysin which caused lysis of the bacterium, ${ }^{17}$ Referring to the physicochemical work of Elford, Bechhold and Schlesinger, Wollman concluded that bacteriophage had to be of corpuscular nature. ${ }^{18}$

After criticizing the diastatic (endogenous) theory of the nature of bacteriophage, Wollman argued that this did not imply that the "virus theory" had to be accepted. Before this theory could be accepted the exogenous origin of bacteriophage would first have to be established, something which appeared very unlikely to him, because of the existence of lysogenic bacterial cultures. The facts which a coherent theory should be able to explain were "on the one hand the corpuscular elements [bacteriophages] behaving in every way like living things, on the other the bacterial endogenous origin of these elements."19

15. Eugène Wollman, "The Phenomenon of Twort-d'Hérelle and its Significance," Lancet, $i$, (1935), 1312-1314.

16. Eugène Wollman and Elisabeth Wollman, "Mise en Liberté des Bactériophages d'une Souche Spontanément Lysogène par l'Action du Lysozyme. Application à la Détermination du Rapport Numérique entre Bactéries et Bactériophages," C. R. Soc. Biol., 119 (1935), 47-50.

17. Eugène Woliman, "Bactériophagie (Autolyse Hérédocontagieuse) et Bactériophages (Facteurs Lysogènes)," Bull. Inst. Pasteur, 32 (1934), 945-955; idem, "Recherches sur l'Autolyse. Les Autolysines Spécifiques," C. R. Acad. Sci., Paris, 198 (1934), 1642-1644. Cf. idem, "Significance" (above, n. 15).

18. Wollman, "Significance" (above, n. 15), p. 1313. See, for instance, Heinrich Bechhold and Max Schlesinger, "Zentrifuge und Filter zur Bestimmung der absoluten Größe von subvisiblen Erregern (Pockenvaccine und Hühnerpest)," Ztschr. Hyg. Infekt., 112 (1931), 668-679; Elford and Andrewes. "Sizes" (above, n. 7); reprinted in Hahon, Papers (above, n. 7), pp. 163-170; F. Macfarlane Burnet and Christopher H. Andrewes, "Über die Natur der filtrierbaren Vira," Zentralbl. Bakt. Parasitenk. Infekt., I. Abt., Orig., 130 (1933), 161-183; Heinrich Bechhold, "Ferment oder Lebewesen?," Kolloid-Zischr., 66 (1934), 329-340 and idem, 67 (1934), 66-79.

19. Wollman, "Significance" (above, n. 15), p. 1313. 
Eugène Wollman thought the corpuscularity, the living nature and the endogenous origin of bacteriophage to be in agreement with his theory of the "hereditary factors." This hypothesis, which he had already defended since the 1920s, claimed that bacteriophage was a stable element of cellular origin, which acted as a material basis for certain hereditary characteristics. Thus, bacteriophage being a facteur héréditaire, bacteriophagy was conceived as a bacterial variation in the Mendelian sense, based on a particle of protoplasm, possibly chromatiques. Such a material particle or hereditary factor represented the bacterial variation and was passed on the daughter cell. The hereditary factor or carrier could gain entrance into a normal cell of the same bacterial strain but also into non-related cells and was "transmissible, non seulement de cellulemère à cellules-filles, mais aussi à travers le milieu extérieur de cellule atteinte à cellule normale." 20 The possibility of bacteriophage being free particles made bacteriophagy a contagious disease and represented a newly discovered form of bacterial variation. According to Wollman the term "bacteriophage" could be replaced by the term tysogenic factor and "bacteriophagy" by transmissible autolysis (Bordet) or hereditary contagious autolysis (Wollman). ${ }^{21}$ In summary, the research of the Wollmans resulted in a position linking the exogenous and endogenous thought styles.

However, the theory of the Wollmans was also exposed to criticism. In particular, the presence of a free hereditary factor in the extracellular environment was not an acceptable assumption to everyone. Paul C. Flu, an ardent defender of d'Hérelle's virus hypothesis, took this point as the focus of his criticism on the "theory of the hereditary factors." In a review from 1946, Flu stated that he had to disagree with the Wollmans immediately because "we positively know that isolated genes, the substantial bearers of hereditary qualities, do not leave the chromosomes." A second point of criticism was that it was known from immunology that when a foreign plasma element entered a living organism, it always provoked a defensive reaction. Flu reasoned that the organism reacted "with the production of something 'anti' to that which has been

20. Eugène Wollman and Elisabeth Wollman, "Recherches sur le Phénomène de Twort-d'Hérelle (Bactériophagie)," Ann. Inst. Pasteur, 49 (1932), 41-74, esp. p. 74. See also Wollman, "Autolyse Hérédocontagieuse" (above, n. 17). For later work of the Wollmans see Eugène Wollman and Elisabeth Wollman, "Les 'Phases' des Bactériophages (Facteurs Lysogènes)," C. R. Soc. Biol., 124 (1937), 931-934; idem, "Recherches sur le Phénomène de Twort-d"Hérelle (Bactériophagie ou Autolyse Hérédo-Contagieuse)," Ann. Inst. Pasteur, 60 (1938), 13-57. The "extra-Mendelian" position of the Wollmans is discussed in Richard M. Burian, Jean Gayon and Doris Zallen. "The Singular Fate of Genetics in the History of French Biology, 1900-1940," J. Hist, Biol, 2l (1988), 357-402. See also Galperin, "Bactériophage" (above. n. 4).

21. Wollman, "Significance" (above, n. 15), p. 1313. 
introduced, and never begins to produce the introduced substance." Therefore, an extracellular element could not be brought into the bacterium and be reproduced. ${ }^{22}$

So far we have seen that those who defended the exogenous virus theory were generally suspicious of the existence of lysogeny, while those who developed their theory within the endogenous thought style stressed the role of lysogeny in their interpretation of the observations. It would take until the 1950s before André Lwoff presented experimental observations and formulated a hypothesis of lysogeny which could link the exogenous and endogenous thought styles and could acquire common consent.

\section{Micromanipulation}

André Lwoff felt challenged by Max Delbrück who, as we have seen in the preceding chapters, defended the position that bacteriophage was a bacterial virus and who had doubts about the existence of lysogeny. This is evident from Delbrück's review of bacteriophages from 1946. The cautious claim by Jacques Bronfenbrenner and Alfred Hershey who regarded lysogeny as "one type or another of association between exogenous virus and incompletely susceptible bacterium" was probably also inspired by Delbruck's scepticism. ${ }^{23}$ Delbrück's mistrust of the results of the work of Burnet, den Dooren de Jong and the Wollmans incited André Lwoff and Jacques Monod to reinvestigate lysogeny. ${ }^{24}$

Together with Antoinette Gutmann, André Lwoff initiated the study of one or a few lysogenic bacteria over several generations. By using a lysogenic and relatively large bacterium, $B$. megaterium, and a micromanipulator, they were able to follow

22. Paul C. Flu, "The Bacteriophage: A Historical and Critical Survey of 25 Years Research," Acta Leid. Scholae Med. Trop., 17 (1946), 13-201, esp. p. 67.

23. Max Delbrück, "Bacterial Viruses or Bacteriophages," Biol. Rev., 21 (1946), 30-40; Alfred D. Hershey and Jacques Bronfenbrenner, "Bacterial Viruses: Bacteriophages," in Viral and Rickettsial Infections of Man, ed. Thomas M. Rivers (Philadelphia: J. B. Lippincott Co., 1948), pp. 147-162, esp. pp. 153-154.

24. See Jacques Monod, "Du Microbe à l'Homme," in Les Microbes et la Vie - Of Microbes and Life, ed. Jacques Monod and Ernest Borek (New York: Columbia University Press, 1971), pp. 19, esp. p. 7. Other expressions of the doubts Delbrück had about the validity of the phenomenon of lysogeny can be found in André Lwoff, "From Protozoa to Bacteria and Viruses: Fifty Years with Microbes," Annu. Rev. Microbiol., 25 (1971), 1-26, esp. pp. 14-15; Elie L. Wollman, "Bacterial Conjugation," in Phage and the Origins of Molecular Biology, ed. John Cairns, Gunther S. Stent and James D. Watson (Cold Spring Harbor, New York: Cold Spring Harbor Laboratory of Quantitative Biology, 1966), pp. 216-225, esp. pp. 216-217. 
more than 20 generations of the bacterium. The presence of exogenous bacteriophage was detected by taking micro-samples and analyzing their bacteriophage contents. From their observations Lwoff and Gutmann concluded that the lysogenic function which was perpetuated to the bacterial progeny could not be the result of redistribution of exogenous bacteriophage particles. Therefore, the existence of an endo-microbial route seemed inevitable. Furthermore, it was concluded that bacteriophage was only formed when a bacterium lysed. On the other hand, lysis of $B$. megaterium did not necessarily imply production of bacteriophage, because when the bacterium lysed under anaerobic conditions not a single bacteriophage was liberated. ${ }^{25}$

The crux of the concept of lysogeny as it was proposed by Andre Lwoff in 1950 was that a lysogenic bacterial culture could only be cultured because some bacteria did not produce bacteriophage. For when a bacterium produced bacteriophage the former was fated to die. Therefore, Lwoff distinguished between a lysogenic bacterial culture, where a population of bacteria was considered, and a lysogenic bacterium, where only one individual cell was concerned. ${ }^{26}$ In a lysogenic bacterial culture bacteriophage could and would be present by incidental lysis of a bacterium and the simultaneous

25. André Lwoff and Antoinette Gutmann, "Recherches sur un Bacillus Megatherium Lysogène," Ann. Inst. Pasteur, 78 (1950), 711-739; translated in Papers on Bacterial Viruses, ed. Gunther S. Stent (Boston: Little, Brown and Co., 1960), pp. 312-331. The use of the micromanipulator was described in Pierre de Fonbrune, Technique de Micromanipulation (Paris: Masson. 1949). The number of bacteria which lysed appeared to be very variable (5-30\%). Lwoff and Gutmann supposed that this observation could be explained by two hypotheses, the one a "mutation hypothesis" and the other an "induction hypothesis." Follow-up investigations by André Lwoff, Louis Siminovitch and Niels Kjeldgaard showed that in a suitable medium and under certain conditions, e.g., irradiation with ultraviolet light, all bacteria of a lysogenic culture could be Jysed with release of bacteriophage. Therefore, the production of phage by lysogenic bacteria appeared to depend on induction. See André Lwoff, Louis Siminovitch and Niels Kjeldgaard, "Induction de la Lyse Bactériophagique de la Totalité d'une Population Microbienne Lysogène," C. R. Acad Sci., Paris, 231 (1950), 190-191; translated in Stent, Papers (above), pp. 332-333.

26. Because of this distinction between a lysogenic bacterial culture and a lysogenic bacterium Lwoff was to ascribe the discovery of lysogeny to two simultaneous papers from 1925, by Jules Bordet and Oskar Bail, respectively. [Jules Bordet, "Le Problème de l'Autolyse Microbienne Transmissible ou du Bactériophage," Ann. Inst. Pasteur, 39 (1925), 717-763; Oskar Bail, "Der Kolistamm 88 von Gildemeister und Herzberg," Med. Klin., 21 (1925), 1271-1273.] In these articles it was shown that every single bacterium of a lysogenic bacterial culture had the lysogenic property. In this "discovery account" Lwoff ignored earlier descriptions of lysogeny, which had only addressed the lysogenic quality of the bacterial culture in question. See Lwoff, "Lysogeny" (above, n, 1), pp. 274276. 
production of phage. In a lysogenic bacterium, bacteriophage was only present in potency and when this potential characteristic was expressed this meant that the bacterium lysed and was sentenced to death. To emphasize this difference between the potential characteristic to produce bacteriophage and actual exogenous bacteriophage, Lwoff and Gutmann proposed the concept of probacteriophage or prophage. Because of this distinction, the term bacteriophage had to be used carefully in lysogeny: "One could be tempted to write, as perhaps we ourselves [Lwoff and Gutmann] have done, that potentially lysogenic bacteria live 'in equilibrium' with their bacteriophage. But, in fact, they live in equilibrium with a probacteriophage. There exists an incompatibility between the structure 'bacteriophage-virus' and the survival of the bacterium."27

With the concept of prophage, Lwoff had proposed a hypothesis which linked the exogenous thought style - i.e., bacteriophage as an exogenous bacterial virus with the endogenous thought style - i.e., bacteriophage as an endogenous function of lysogenic bacteria. Together with developments with respect to the genetic function of nucleic acid, these ideas were to form the basis of the "modern concept of virus." 28

\subsection{THE "MODERN CONCEPT OF PHAGE"}

Lwoff's concept of the prophage as an endogenous function of the bacterium linked the exogenous and endogenous thought styles. This section will analyze the subsequent formulation, in the 1950 s, of the "modern concept of phage." In this process two aspects played an important role. First, Lwoff's concept of prophage indeed

27. Lwoff and Gutmann, "Recherches" (above, n. 25), p. 737; translated in Stent, Papers (above, n. 25), pp. 312-331, esp. p. 330. Because Macfarlane Burnet had already stated in 1929 that hacteriophage was present in lysogenic bacteria as an "anlage," he commented ironically on the work of the Arnerican Phage Group and that of André Lwoff and his co-workers: "at times I have had a slightly twisted pleasure in watching Americans or Frenchmen discover in the forties what we had clearly described between 1927 and 1935. (...) I think that even a layman can see that basically the interpretation [of lysogeny] did not change much in thirty-five years." See Macfarlane Burnet, Changing Patterns, an Atypical Autobiography (London: W. Heinemann, 1968), p. 53 and p. 56

28. Lwoff's concept of prophage was positively received because in the late 1940s phage research had pointed out that multiplying phage lost its integrity, which made Lwoff's suggestion more plausible. When the notion of the genetic function of nucleic acid was suggested in the early 1950s, this fitted in with the idea of an eclipse of phage during multiplication and with the concept of prophage. The impact in the 1960s of the notion that nucleic acid shows biological activity is illustrated in Frank L. Horsfall, Jr., "Some New Concepts in Biology," Arch. Biochem. Biophys., Suppl. I (1962), 63-67. 
constituted a bridge between the two thought styles, but the idea of bacteriophage and prophage as exogenous particles was retained. Second, another link between the exogenous and endogenous thought styles was achieved by the research of phage multiplication by biochemists. Using the "one-step growth technique" (introduced from the exogenous thought style of Delbrück) biochemists concluded that bacteriophage depended for its multiplication on the metabolism of the bacterial host cell.

\section{An autonomous endogenous function}

Although in the concept of prophage bacteriophage was conceived as an endogenous function, it was still thought of as autonomous. This is apparent from the publication by André Lwoff and Antoinette Gutmann in which they describe their research with the micromanipulator. In the diagram in which they summarized their notions of bacteriophagy, lysogeny and prophage, they represented prophage as an open circle while bacteriophage-virus was drawn as a somewhat larger closed circle. That prophage was thought of as an autonomous particle can be derived from their representation of the "growth" of the prophage (after induction) as the enlargement of the open circle. In the next phase the large open circle, i.e., mature prophage, disintegrated into numerous closed circles, i.e., infectious bacteriophage particles. How prophage grew and how the production of phage particles from prophage occurred was not known and remained a mystery. ${ }^{29}$

In the early 1950 s the concept of prophage was to be more precisely articulated. More and more it was argued that during the phase in which new phage particles were produced, the reproduction of bacteriophage was solely guided by the nucleic acid of the phage particle. This part of the "life cycle" of bacteriophage came to be called the vegetative phase. The multiplication of bacteriophage during its vegetative phase was represented as the multiplication of prophage (Lwoff and Gutmann, 1950). A few years later, Lwoff introduced a new form in which bacteriophage could exist, namely, as a gonophage. This term referred to the genetic material of bacteriophage in the vegetative phase, which probably consisted only of nucleic acid. According to this scheme of lysogeny, bacteriophage could be found as phage-virus, prophage or gonophage. ${ }^{30}$ It was later concluded that prophage too consisted only of nucleic acid, and

29. See figure in Lwoff and Gutmann, "Recherches" (above, n. 25), p. 736; translated in Stent. Papers (above, n. 25), pp. 312-331, esp. p. 329. The figure is also reproduced in Galperin. "Bactériophage" (above, n. 4), p. 224. An interesting analysis of the use of photographs and figures in reporting scientific observations can be found in Jane Maienschein, "From Presentation to Representation in E. B. Wilson's The Cell," Biol. Phil., 6 (1991), 227-254. 
Lwoff's distinction between the concepts of prophage and gonophage was abandoned.

Lwoff's research programme was still very much influenced by the idea of bacteriophage as an autonomous particle, as is also apparent from the autonomous character of the prophage and its identification as a particle. This becomes even clearer when Lwoff's position is confronted with the ideas of a biochemist, which conflicted with the assumption of independence. Since Lwoff had only shown the absence of a bacteriophage particle in lysogenic bacteria and not the presence of a prophage particle, another, physiological interpretation of prophage was also possible. In 1952 the biochemist Earl A. Evans, Jr., interpreted prophage as a "physiological condition." $\mathrm{He}$ wrote that it would be possible to regard the prophage not as "a molecular entity but rather a system - a part of the normal metabolic apparatus of the bacterial cell, which, under the stimulus of a virus particle, is so altered as to manufacture the viral progeny." 31 A final argument for the thesis that Lwoff interpreted prophage as an autonomous particle can be found in the mechanism he suggested for the way prophage was converted into the vegetative phase. Lwoff suggested that, after induction, the attraction of the prophage for a "key enzyme" could be stronger than that of the bacterial particles for that enzyme. ${ }^{32}$

\section{A biochemical approach}

Lwoff's notion of prophage as an autonomous particle with an endogenous phase contrasted with the endogenous thought style, within which biochemists like Seymour S. Cohen, Earl A. Evans, Jr., Lloyd M. Kozloff and Frank Putnam performed their research. The fundamental difference between the methods of those who worked within the exogenous thought style (it is my claim that Delbrück and Lwoff belonged to these) and those who worked within the endogenous thought style (e.g., the bio-

30. Lwoff, "Lysogeny" (above, n. 1), p. 272.

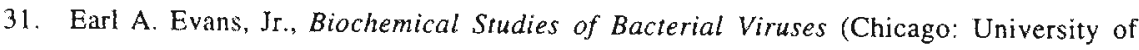
Chicago Press, 1952), p. 67.

32. The quotation runs as follows: "the equilibrium is perturbed possibly because the attractive power of the bacterial particles is diminished or because the attractive power of the probacteriophage is increased, the latter will develop and give rise to bacterial virus particles." See Lwoff and Gutmann, "Recherches" (above, n. 25), p. 734; translated in Stent, Papers (above, n. 25), pp. 312-331, esp. p. 327. The concept of a "key enzyme" in the study of the multiplication of bacteriophage was introduced in Max Delbrück and Salvador E. Luria, "Interference between Bacterial Viruses. I. Interference between Two Bacterial Viruses Acting upon the Same Host, and the Mechanism of Virus Growth," Arch. Biochem., I (1942), 111-141. For a brief discussion of the role of the phenomenon of viral interference in the history of virus research see Chapter 7 of the present study. 
chemists mentioned above) is apparent from the following quotation by Earl A. Evans, Ir.: "The contributions of the chemist to the rapidly developing understanding of this process [the mechanism of viral reproduction] must necessarily lag behind the more dexterous explorations of the microbiologist and geneticist, but they have the virtue of carrying the description, even though incomplete, to the ultimate molecular level."33 Thus, Evans perceived a contrast between the work of the microbiologists and geneticists who studied phage as an autonomous infectious particle with genetic properties and the work of the (bio)chemists, who sought to explain the multiplication of bacteriophage at the molecular level of (biological) chemistry.

One of my claims is that Delbrück, although his prime motivation for studying viruses was that plant viruses could be recognized as molecules, analyzed bacteriophage at the level of an infectious particle with genetic properties, i.e., as an organism. This is also illustrated in a quotation by August $\mathrm{H}$. Doemann in the "Festschrift" for Delbruck in 1966: "The premolecular biologists of twenty years ago considered bacterial viruses to be parasitic microorganisms whose life cycles were only superficially understood. The organismic view found rather forceful support from the early studies of virus mutation by Luria (1945) and by Hershey (1946) and from the first demonstration by Delbrück and Bailey (1946) of genetic recombination among these forms." 34 [Italics mine.] By contrast, biochemists of the "Phage Group" studied the multiplication of bacteriophage in terms of metabolism and, as the years went on, as bacterial metabolism.

Since the mid 1940s Seymour S. Cohen had been using the "one-step growth technique" to study the metabolic effects of the formation of bacteriophage. This would result in a use of this technique which was completely different from the way it was used by Delbrück. Using this experimental method, Delbriick studied the multiplication of bacteriophage in "interference experiments," in which a bacterium was interpreted as a "black box." In this way, parental virus ("input") and virus progeny ("output") were observed at the level of infectious particles. ${ }^{35}$ By contrast, Cohen's

33. Earl A. Evans, Jr., "The Biochemistry of the Bacterial Viruses," in Essays in Biochemistry, ed. Samuel Graff (New York: John Wiley \& Sons, 1956), pp. 94-105, esp. p. 94.

34. August H. Doermann, "The Eclipse in the Bacteriophage Life Cycle," in Cairns, Stent and Watson, Phage (above, n. 24), pp. 79-87, esp. p. 79. The reference is to: Salvador E. Luria, "Mutations of Bacterial Viruses Affecting their Host Range," Genetics, 30 (1945), 84-99; Alfred D. Hershey, "Mutation of Bacteriophage with Respect to Type of Plaque," idem, 3 I (1946), 620-640: Alfred D. Hershey, "Spontaneous Mutations in Bacterial Viruses," C. S. H. Symp. Quant. Biol., II (1946), 67-77: Max Delbrück and W. T. Bailey, Jr., "Induced Mutations in Bacterial Viruses," idem (1946), 33-37; the latter article was reprinted in Hahon, Papers (above, n. 7), pp. 198-207. 
premise was that the growth of bacteriophage could be studied by varying the extracellular medium. In this way he studied, for instance, the de novo synthesis of nucleic acid from inorganic phosphate present in the extracellular medium. Cohen concluded that their data indicated that "the energy and substance for virus synthesis are supplied in entirely normal fashion by the parasitized cell ...". 36 He also stated that autocatalysis as a model for the multiplication of phage was no longer tenable. A mechanism for virus synthesis which was still usable was "the time-worn template hypothesis, since virus does not seem to be a self-duplicating unit at all but rather a duplicated unit. Thus the virus appears to be synthesized by the cell according to the models (templates) which it provides for the host's enzymes." 37 Cohen's research not only validated the physiological, endogenous interpretation of the formation of bacteriophage, it also represented a criticism on a fundamental assumption of the exogenous thought style, namely, that phage multiplied autonomously, either via binary fission or autocatalysis.

Until well into the 1940 s the multiplication of viruses was often thought to occur by way of binary fission. The notion that the host cell was no more than a useful "nutrient medium" for the multiplying autonomous virus was popular among those who studied plant or animal viruses. In 1942, Max Delbrück had expressed this situation as follows: "One often hears the view expressed, particularly among scientists who work with animal and plant viruses, that the cell provides a suitable nutrient medium for the virus and that the virus grows in this medium as a bacterium would grow in a cell-free nutrient medium. But the indications are that the dependence of the virus on the cell goes deeper. (...) The virus makes use of the metabolic machinery of the cell for its own needs." ${ }^{38}$ But within the exogenous thought style of bacteriophage

35. Seymour S. Cohen, Virus-Induced Enzymes (New York: Columbia University Press, 1968), pp. 6-7. Cf. Brock, Emergence (above, n. 4), pp. 156-157.

36. Seymour S. Cohen, "The Synthesis of Bacterial Viruses in Infected Cells," C. S. $H$. Symp. Quant. Biol., 12 (1947), 35-49, esp. p. 46. The discovery by Seymour Cohen of the dependence of virus multipication on bacterial enzymes and energy has only rarely been recognized as an important event. An exeption can be found in André Lwoff, "Introduction [au Ve Congrès International de Virologie (IAMS), 2-7 août 1981, Strasbourg]," Ann. Virologie, 132 E (1981), 121-134, esp. p. 124.

37. Cohen, "Synthesis" (above, n. 36), p. 46.

38. Max Delbrück, "Bacterial Viruses (Bacteriophages)," Adv. Enzym., 2 (1942), 1-32, p. 30. The presupposition that (animal) viruses grew by a mechanism of binary fission is, for instance, apparent from the response Leslie Hoyle got when he published his work on influenza virus. See Ton van Helvoort, "A Bacteriological Paradigm in Influenza Research in the First Half of the Twentieth 
research binary fission had also functioned as a model for the multiplication of bacteriophage. In principle, this notion was based on an organismal or microbial concept of the nature of bacteriophage, which is illustrated by a quotation by Alfred Hershey in 1956. Hershey asked the question what the old assumption had been about the multiplication of bacteriophage. To this he formulated the following answer:

... by analogy with other parasites, one could suppose that the infecting virus particle [bacteriophage] undergoes minimal modifications (softening of surface structures, loss of ability to survive in the naked state, elaboration of enzymes) preparatory to growth in size and multiplication by fission. Loss of infectivity and the main facts of genetic recombination were thus accounted for, and linkage to bacterial metabolism could be explained by dependence on one or more specialized substrates normally manufactured by the cell. This analogy seemed perfectly satisfactory, as indeed it was, to the majority of virologists. ${ }^{39}$

Within bacteriology, binary fission was thought to be synonymous with concepts like multiplication and growth (increase in the number of bacteria). One result of the biochemical research on the multiplication of bacteriophage was that for bacteria one had to distinguish growth (increase in size) from the process of division. Growth and division together resulted in multiplication of a bacterium. In 1949 Seymour Cohen concluded that for bacteria the concepts of growth and multiplication could no longer be equated. But as infectious bacteriophage of a certain strain always seemed to be of a single size (i.e., apparently not growing in size before its division) Cohen argued that for bacteriophage the concepts of growth and multiplication could still be used as synonyms. ${ }^{40}$

That binary fission could not be the process by which bacteriophage multiplied became also apparent from the research by Frank Putnam and Lloyd M. Kozloff. In 1950 these researchers reported that the original infecting phage particle disintegrated within the bacterial cell and that only one third of the phosphorus content of the parent phage could be traced in the phage progeny. ${ }^{41}$ These biochemical studies led the Century," Hist. Phil. Life Sci., 15 (1993), in press; included as Chapter 3 of the present study.

39. Hershey, "Bacteriophage T2" (above, n. 3), 230-231.

40. Seymour S. Cohen, "Growth Requirements of Bacterial Viruses," Bact. Rev., 13 (1949), 1-24, esp. p. 1, footnote 1.

41. Frank W. Putnam and Lloyd M. Kozloff, "Biochemical Studies of Virus Reproduction. IV. The Fate of the Infecting Virus Particle," J. Biol. Chem., 182 (1950), 243-250. See also Lloyd M. Kozloff, "Origin and Fate of Bacteriophage Material," C. S. H. Symp. Quant. Biol, 18 (1953), 209220; idem, "Transfer of Parental Material to Progeny," in Cairns, Stent and Watson, Phage (above, 
biochemist Evans to the puzzling conclusion that the "essential feature of phage reproduction is a replication of form and not substance." 42

\section{The formation of consensus}

This discussion of the multiplication of phage and the genetic and biochemical studies on this subject has constituted an introduction of the elements which formed the basis of Lwoff"s definition of bacteriophage as "nucleoprotein particles possessing only one type of nucleic acid, unable to grow and to undergo binary fission and reproduced from their nucleic acid." 43 The description of bacteriophage as presented by Lwoff in his renowned Marjory Stephenson Memorial Lecture is summarized in Table 6.1.

TABLE 6.1: Characterization of the three phases - prophage, vegetative phage and infectious phage - in the "life cycle" of bacteriophage in terms of structural and functional properties (after André Lwoff, 1957). ${ }^{44}$

Specific nucleic acid

Replication of nucleic acid Protein synthesis

Pathogenicity

Morphogenesis of particles

Infectivity

$\begin{array}{ccc}\text { Prophage } & \begin{array}{c}\text { Vegetative } \\ \text { Phage }\end{array} & \begin{array}{c}\text { Phage } \\ \text { Particle }\end{array} \\ + & + & + \\ 0 & + & 0 \\ 0 & + & 0 \\ 0 & 0 & +\end{array}$

According to this definition bacteriophage is characterized by having three phases, the nucleic acid being the only material basis which is common to all. Only the "mature" phage particle is infectious and the hereditary information of bacteriophage is conserved in the form of its genetic material, which is the form in which it replicates, i.e, , phage does not multiply via binary fission. André Lwoff used this description of n. 24), pp. 109-115; idem, "Phage Biochemistry and the Origin of Molecular Biology," Trends Biochem. Sci., 9 (1984), 422-423.

42. Earl A. Evans, Jr., "The Origin of the Components of the Bacteriophage Particle," Ann. Inst. Pasteur, 84 (1953), 129-142, esp. p. 142.

43. Lwoff, "Lysogeny" (above, n. 1), p. 332. See also Chapter 7 of the present study.

44. Lwoff, "Concept" (above, n. 1), p. 243. The term "life cycle" is placed between quotation marks because the different phases need not to pass off in a specific chronological order. For a discussion of life cycles in bacteria see, for instance, K. A. Bisset, The Cytology and Life-History of Bacteria (Edinburgh: E. \& S. Livingstone, 1950). 
bacteriophage to define his general concept of virus.

In the early 1950s, as was said above, Lwoff regarded prophage as an endogenous function of the bacterium, but at the same time as an autonomous particle. François Jacob had done research on the question where prophage was located and he considered two situations to be possible. On the one hand, there was the possibility that prophage was a cytoplasmatic particle or on the other hand, it might be that it constituted a genetic element linked to a specific structure in the cell, e.g., the nucleus. In 1954 this question was answered by Jacob with the claim that in a Jysogenic bacterium prophage was bound to chromosomal material of the bacterium. ${ }^{45}$ Retrospectively, François Jacob and Elie Wollman would state that the opposite notion had been the current opinion and "the hypothesis of a cytoplasmic determination of lysogeny had been accepted implicitly." 46

The work of Lwoff and his co-workers on the lysogenic strain of B. megaterium led to unexpected results, especially for those who had worked with virulent phages and had thought of bacteriophages as exogenous agents $(e . g .$, microbiologists and geneticists). The recognition of the limitations which of working with virulent phages was caused particularly by the discovery that $E$. coli $\mathrm{K} 12$, which had been used in important work with virulent phages, was lysogenic too.47 In 1953 Esther and Joshua Lederberg wrote that bacteriophages of the $\mathrm{T}$-series were chosen for their study because of their atypical virulence, the limited occurrence of resistant bacterial cultures and their clear plaques. But, as they stated, it would be a mistaken idea to generalize too soon about the biology of bacterial viruses on the basis of the study of a "restricted set of materials." 48

This was no overstatement, because at the very moment that the "modern concept of phage" was being formulated, a presupposition of this concept was already being rejected. It was found that linking the genetic material of the prophage to that of the bacterial cell was not without its consequences for the properties of the bacterium. This constituted a falsification of the notion that one had to think of bacteriophage as

45. François Jacob, Les Bactéries Lysogènes et la Notion de Provirus (Paris: Masson, 1954), pp. 127-133.

46. François Jacob and Elie L. Wollman, Sexuality and the Genetics of Bacteria (New York: Academic Press, 1961), p. 90. Cf. Joshua Lederberg, Esther M. Lederberg, Norton D. Zinder and Ethelyn R. Lively, "Recombination Analysis of Bacterial Heredity," C. S. H. Symp. Quant. Biol., I6 (1951), 413-443. See also Brock, Emergence (above, n. 4), pp. 182-185.

47. Esther M. Lederberg, "Lysogenicity in E. coli K12," Genetics, 36 (1951), 560.

48. Esther M. Lederberg and Joshua Lederberg, "Genetic Studies of Lysogenicity in Escherichia Coli," Genetics, 38 (1953), 51-64, esp. p. 62. Cf. Stent, Molecular Biology (above, n. 4). p. 390. 
an autonomous entity. A contrary move in the dynamics between the exogenous and endogenous thought styles was that one had to drop, to a certain extent, the notion that phage replication was the result of bacterial metabolism. It was claimed that bacteriophage had building blocks which did not belong to the normal products of the bacterial cell. The enzymatic synthesis of these components was apparently executed by bacteriophage, thus reinforcing the autonomous nature of the latter.

\section{4 "INFECTIOUS HEREDITY" REVISITED}

Despite the reinforcement of the endogenous thought style by the concept of prophage and the discovery of the dependence of phage replication on bacterial metabolism in the early 1950s, the interpretation of bacteriophage as autonomous still prevailed for many researchers. Thus, the biochemist Seymour S. Cohen in 1945 phrased the dependence of (bacterial) virus multiplication on the host cell metabolism by saying that "a virus is a parasite which organizes a specific enzymatic environment for its own multiplication." 49 Research by Cohen and G. R. Wyatt in the 1950 s fundamentally changed the notion of the dependency of bacteriophage on bacterial metabolism, i.e., bacterial enzymes and building blocks. These researchers established that the nucleic acid of bacteriophages of the T-even series contained a nucleic acid, 5-hydroxymethylcytosine, which was not present in the nucleic acid of the host and thus was virusspecific. ${ }^{50}$ Thus, it was concluded that the DNA of bacteriophage was characterized by a specific nucleotide, which meant that phage DNA and bacterial DNA could be distinguished with the help of chemical techniques. Alfred Hershey concluded that "the quantitative chemical distinction between bacterial and viral DNA now appears to be feasible." 51 Retrospectively, Seymour Cohen was to write that he had already become "suspicious of the validity of a key biochemical dogma of the time, namely, the 'unity of biochemistry.' This hypothesis focused on many apparently ubiquitous biochemical compounds and processes known in the 1940s, and neglected numerous other esoteric 'irrelevancies.' It proposed not only a monophyletic biochemical evolution but a general methodology of biochemical research as well, developing the notion

49. Cohen, "Synthesis" (above, n. 36), p. 46.

50. G. R. Wyatt and Seymour S. Cohen, "The Bases of the Nucleic Acids of Some Bacterial and Animal Viruses: The Occurrence of 5-Hydroxymethylcytosine," Biochem. J., 55 (1953), 774782.

51. Alfred D. Hershey, "Intracellular Phases in the Reproductive Cycle of Bacteriophage T2," Ann. Inst. Pasteur, 84 (1953), 99-112, esp. p. 110. Cited in Cohen, Virus-Induced Enzymes (above, n. 35$)$, p. 24 . 
that results obtained with one type of biological material could be readily extrapolated to all biological material." 52

In their research programme, Cohen and his co-workers sought for the metabolic origin of this phage-specific nucleic acid and for the enzyme which provided its synthesis. They found that in a phage infected cell, the enzymatic apparatus was extended, which was designated by Cohen as a "virus-induced acquisition of metabolic function." 53 The discovery of phage specific nucleic acid and phage specific enzymes in infected cells would contribute in the 1950s and 1960s to the elucidation of one of the most important problems of cellular physiology, i.e., the synthesis of protein. It contributed to the rephrasing of the problem of protein synthesis in terms of genetic control and phenotypic expression of genes. ${ }^{54}$ With the finding of phage specific enzymes, the biochemical study of phage was in fact transferred from the endogenous thought style to the exogenous thought style. By contrast, genetically oriented research of phage went through a shift in the opposite direction.

In lysogenic bacteria it was found that the genetic information of bacteriophage entered into an interaction with the genetic material of the bacterium. In 1954, André Lwoff, in an article entitled "Some Aspects of Metapoietic Integrations," discussed what happened when such an integration took place. He argued that prophage was the genetic material of bacteriophage as it was modified by its binding to a specific spot on the bacterial chromosome. In turn, the bacteriophage influenced some of the properties of the bacterium, as if it exerted an influence on bacterial genes. Therefore, the properties of a lysogenic bacterium were the result of the integration of the genetic material of the bacterial cell and the bacteriophage. Such an integration resulted in modifications in the properties of the bacterium, and Lwoff named this "metapoietic," which means "generating changes." In lysogeny, the prophage became a component of the bacterium and took "part in the daily life of the bacterium as if it were a cog in the bacterial machinery. It plays its part in the molecular orchestra." 55 In the review of bacterial genetics by Elie Wollman and François Jacob in 1961, bacteriophage was therefore defined as "the structure which, in lysogenic bacteria, carries the genetic

52. Cohen, Virus-Induced Enzymes (above, n. 35), p. 23.

53. See, for instance, ibid., pp. 57-58.

54. See "Gene Expression and Regulation," in Brock, Emergence (above, n. 4), pp. 265-324.

55. André Lwoff, "Some Aspects of Metapoietic Integrations," in Perspectives and Horizons in Microbiology, ed. Selman A. Waksman (New Brunswick, New Jersey: Rutgers University Press, 1955), pp. 13-23, esp. p. 23. See also André Lwoff, "Control and Interrelations of Metabolic and Viral Diseases of Bacteria [Lecture delivered on 16 December 1954.]," Harvey Lect., 50 (1956), 92 111. 
information necessary for the production of a given type of bacteriophage and which confers on these bacteria certain specific hereditary properties." 56

However, Lwoff's suggestion of "metapoietic integrations" was destined not to reach the stage of incorporation into textbooks, and some of the integration phenomena he had referred to would become designated as "conversion." The best known example of "phage conversion" concerned the production of toxin by the pathogenic bacterium Corynebacterium diphteriae, which was first described by Victor Freeman in 1951. Freeman had observed that exposing a phage susceptible avirulent culture of C. diphteriae to "phage B" resulted in the production of a virulent lysogenic strain. 57 These studies were continued by Neal Groman who in 1953 concluded that toxigenicity and lysogenicity were obtained simultaneously during phage infection. ${ }^{58}$

A second example of a "metapoietic integration," which was discussed by Lwoff in 1954, was the work of Hélène Ionesco. She had found that when a certain strain of $B$. megaterium was lysogenized with a certain bacteriophage, rough colonies formed instead of the normal smooth ones. The presence of the prophage brought about a change in the manner in which the chains of bacilli piled up and colonies were formed, which is one aspect of the phenomena of $S$ and $R$ forms of bacteria. ${ }^{59} \mathrm{~A}$ third

56. Jacob and Wollman, Sexuality (above, n. 46), p. 27.

57. Victor J. Freeman, "Studies on the Virulence of Bacteriophage-infected Strains of Corynebacterium Diphteriae," J. Bact., 61 (1951), 675-688; Victor J. Freeman and I. Una Morse, "Further Observations on the Change to Virulence of Bacteriophage-Infected Avirulent Strains of Corynebacterium Diphteriae," idem, 63 (1952), 407-414.

58. Neal B. Groman, "Evidence for the Induced Nature of the Change from Nontoxigenicity to Toxigenicity in Corynebacterium Diphtheriae as a Result of Exposure to Specific Bacteriophage," $J$. Bact., 66 (1953), 184-191; idem, "Evidence for the Active Role of Bacteriophage in the Conversion of Nontoxigenic Corynebacterium Diphtheriae to Toxin Production," idem, 69 (1955), 9-15. Cf. idem, "The Relation of Bacteriophage to Human Disease: A Review of Conversion to Toxigenicity in Corynebacterium Diphteriae," in Immunity and Virus Infection, ed. Victor A. Najjar (New York: John Wiley \& Sons, 1959), pp. 196-205; Lane Barksdale, "Symposium on the Biology of Cells Modified by Viruses or Antigens - I. Lysogenic Conversions in Bacteria," Bact. Rev., 23 (1959), 202-212; Brack, Emergence (above, n. 4), pp. 206-209.

59. Hélène Ionesco, "Sur une Propriété de Bacillus Megaterium Liée à la Présence d'un Prophage," C. R. Acad. Sci., Paris, 237 (1953), 1794-1795. On S and R forms of bacteria, see also Olga Amsterdamska, "Medical and Biological Constraints: Early Research on Variation in Bacteriology," Soc. Stud. Sci., 17 (1987), 657-687; idem, "Stabilizing Instability: The Controversy over Cyclogenic Theories of Bacterial Variation during the Interwar Period," J. Hist. Biol, 24 (1991), 191-222. 
example cited by Lwoff was the work of his own research group on "immunity" obtained by a lysogenic bacterium against homologous bacteriophage. ${ }^{60}$

In the 1950s several other examples were found of properties of bacteria which were influenced by a temperate bacteriophage. ${ }^{61}$ In addition to Ionesco's results, other observations with regard to external characteristics of bacteria were also linked with the phenomenon of lysogenization: changes in the appearance of bacterial colonies ${ }^{62}$; changes in the morphology of cells ${ }^{63}$; and changes in the synthesis of surface antigens (e.g., the synthesis of polysaccharides in salmonellae). ${ }^{64}$

\section{Bacteriophagy as a genetic metabolic disease}

The studies of "metapoietic integrations" described above had important consequences for the definition of viruses. This can be illustrated by quoting several definitions proposed by Salvador E. Luria through the years. A simple operationalization of the concept of a virus was Luria's description of these entities, in 1950, as "an exogenous submicroscopic unit capable of multiplication only inside specific living cells." The way bacteriophage or bacterial virus multiplied was described by him as the suppression of the synthesis of specific bacterial components in the phage infected bacterium. The notion of bacteriophage as a genetic entity was found by Luria to be relevant in the case of bacteriophagy as well as in lysogeny. The "disruption" of the genetic apparatus of the bacterium and its replacement by that of the bacteriophage resulted in the synthesis by the available bacterial enzymatic machinery of phage specific material. The bacteriophage which was introduced into the host bacterium not only acted as an added "organizer of specificity" but one which completely overruled the organizer of bacterial origin. This process was designated as "parasitism at the genetic level." The endogenous function of prophage in lysogeny which had been

60. See Lwoff, "Lysogeny" (above, n. 1), pp. 314-319; Jacob, Provirus (above, n. 45), pp. 78-104. Cf. Brock, Emergence (above, n. 4), pp. 178-179.

61. See Jacob and Wollman, Sexuality (above, n. 46), pp. 22-23.

62. Dooren de Jong, "Bakteriophagie. I. Mitteilung" (above, n. 13); Ionesco, "Propriété" (above, n. 59).

63. Eugène Wollman and Elisabeth Wollman, "Recherches sur le Phénomène de Twort-d'Hérelle (Bactériophagie ou Autolyse Hérédo-Contagieuse)," Ann. Inst. Pasteur, 60 (1938), 13-57.

64. Shoei Iseki and Tatsuo Sakai, "Artificial Transformation of O Antigens in Salmonella E Group. I. Transformation by Antiserum and Bacterial Autolysate," Proc. Japan Acad, 29 (1953), 121-126; idem, "Artificial Transformation of O Antigens in Salmonella E Group. II. AntigenTransforming Factor in Bacilli of Subgroup $E_{2}$," idem, 29 (1953), 127-131. See also Barksdale, "Conversions" (above, n. 58). 
described shortly before by Lwoff and Gutmann, was designated by Luria as the simultaneous existence of the genetic pattern of the host and the bacterial virus which could function side-by-side in "genetic symbiosis." 65

By the late 1950s, Luria's opinion on the nature of viruses had undergone a considerable metamorphosis. In 1959 Luria claimed it would be more accurate to describe virus diseases as "genetic diseases, more akin to metabolic diseases than to bacterial or protozoan infections." 66 This signalled his departure from the exogenous thought style, i.e., the metaphor by which a virus infection was interpreted as the multiplication of an autonomous infectious agent. This was replaced by an endogenous interpretation of bacteriophagy, viz., a genetic metabolic disease.

A few years later, Luria was to argue that the study of virus infections had become part of cellular genetics. Studies of the interactions between viral and cellular genetic functions led him to conclude that "infection with a virus is not just a disrupting intrusion; it is an addition to the cellular endowment of genetic specificity."67 In this way, Luria had exchanged his definition of a virus infection as genetic parasitism for a definition of virus infection as infectious heredity. Thus, in the early 1960 s he arrived at a position which had been defended by the Wollmans thirty years before.

\subsection{CONSTRUCTION OF BACTERIOPHAGE AS BACTERIAL VIRUS}

Within the exogenous thought style bacteriophage was conceived of as an exogenous and autonomous entity which seemed to belong to the category of (filterable) viruses. Formation of bacteriophage was mostly thought of as the result of the multiplication of a bacteriophage-virus. In the preceding two chapters, two specific research programmes within the exogenous thought style have been discussed. First there was the research of Félix d'Hérelle, who considered bacteriophage to be an ultravirus with properties of living beings, such as assimilation, multiplication and adaptation. Lysogeny was interpreted by him as a "bacteriological contamination," i.e., a form of symbiosis between bacterium and bacteriophage. A second example was the work of Max Delbrück. He interpreted bacteriophage as a bacterial virus and also doubted the

65. Salvador E. Luria, "Bacteriophage: An Essay on Virus Reproduction," Science, 111 (1950), 507-511, esp. p. 507 and p. 510, respectively.

66. Salvador E. Luria, "Viruses: A Survey of Some Current Problems," in Virus Growth and Variation - Ninth Symposium of the Society for General Microbiology, ed. Alick Isaacs and B. W. Lacey (Cambridge: Cambridge University Press, 1959), pp. 1-10, esp. p. 7. Cf. idem, "Viruses as Infective Genetic Materials," in Najjar, Immunity (above, n. 58), pp. 188-195.

67. Salvador E. Luria, "Bacteriophage Genes and Bacterial Functions," Science, 136 (1962), 685-692, esp. p. 692. 
very existence of lysogeny. Delbrück held the opinion that viruses were the smallest living organisms and therefore represented the most simple example of genetic continuity. He used bacteriophagy as a simple model for the study of gene replication. On this basis of genetic experiments as well as electron microscopic observations, Delbrück would later conclude that the presupposition of phage being a simple genetic model, had to be abandoned.

The work of Jules Bordet is an example of the endogenous thought style within phage research. Bordet sought the explanations for his observations concerning bacteriophagy - designated in his terminology as transmissible bacterial lysis within the physiology of the bacterial host cell. In this context, physiology was broadly defined, and also covered phenomena which are now considered part of bacterial genetics. Bordet explained the hereditary character of some changes in bacteria under the influence of bacteriophage as "physiological heredity." Lwoff later stated that perhaps it was precisely this broad and somewhat vague definition of "heredity" by Bordet that led to the discovery of the phenomenon of lysogeny. 68 John H. Northrop was the second exponent of the endogenous thought style discussed here; he studied the formation of bacteriophage as a prototype of protein synthesis. In his research programme too, the phenomenon of lysogeny played a crucial role, and he attempted to explain the formation of phage from the concept of autocatalysis.

In addition to these specific research programmes which belong to one of the two thought styles, in this chapter the work has been discussed of researchers who tried to link the two thought styles, such as Burnet, the Wollmans and Lwoff. The work of Andre Lwoff on lysogenic bacteria in the early 1950s resulted in consensus on how, within the exogenous thought style, bacteriophagy could be reconciled with observations on lysogeny, a phenomenon which constituted a central observation within the endogenous thought style. Bacteriophagy, the multiplication of infectious phage particles, was interpreted as the result of a genetic "take-over" of the bacterial enzymatic machinery and was characterized by the concept of "genetic parasitism." In a lysogenic bacterium the prophage was enclosed as an endogenous particle in the bacterium and was thus transmitted to lysogenic daughter cells as a hereditary property.

In the "modern concept of phage," formulated by Lwoff in 1957, two factors contributed to the forming of consent about the question whether bacteriophage was a

68. André Lwoff said about Jules Bordet's position that "Everything was physiological heredity. ... perhaps lysogeny was discovered precisely because of these somewhat strange conceptions of bacteriophage and of heredity." See Lwoff, "Lysogeny" (above, n. 1), p. 276. 
bacterial virus. The first was that lysogeny had now found "recognition" within the exogenous thought style. The second factor contributing to the consensus was that the knowledge that had been obtained about bacteriophage also led to a redefinition of the category of viruses. This category was "freed" from entities which did not conform to the definition of viruses according to the "modern concept of phage" (e.g., infectious entities which multiplied by binary fission or were inhibited by antibiotics). In this way, bacteriophage eventually obtained a place as a bacterial virus, while infectious disease-causing agents like Rickettsiae, Chlamydiae and PPLO organisms (mycoplasma) were placed outside the virus category. ${ }^{69}$ That bacteriophage was not conceived in the 1940 s as a bacterial virus by many researchers is clear from, for instance, a quotation from Thomas Anderson who in 1966 wrote that many of the members of the "Phage Group" were involved in "a plot to interest the "real plant and animal virologists' in bacteriophages by calling them 'bacterial viruses'."70

With respect to the "modern concept of phage" two contrary developments took place in the 1950s. The first development strengthened the autonomous interpretation of bacteriophage, while the second reinforced the endogenous interpretation. From the biochemical study of the multiplication of bacteriophage — belonging to the endogenous thought style - it was concluded that phage material could be distinguished from bacterial substances by means of chemical techniques. This was interpreted by Seymour Cohen as running counter to the dogma of the "unity of biochemistry" and reinforced the autonomous interpretation of bacteriophage. A contrary development took place within the research — belonging to the exogenous thought style - which studied bacteriophage by means of genetic techniques. Here it was concluded that in lysogenic bacteria the genetic material of the bacterium and that of bacteriophage interacted with each other. Apparently, bacteriophagy as genetic parasitism of the bacterial metabolic machinery by exogenous material was too narrow a point of view. At the

69. For a discussion of the biology of the Rickettsiae, chlamydozoa and PPLO organisms see, for instance, Richard A. Ormsbee, "Rickettsiae (as Organisms)," Annu. Rev. Microbiol., 23 (1969), 275-292; Emmy Klieneberger-Nobel, "Mycoplasma, A Brief Historical Review," Ann. N. Y. Acad. Sci. 143 (1967), 713-718: James W. Moulder, "The Relation of the Psittacosis Group (Chlamydiae) to Bacteria and Viruses," Annu. Rev. Microbiol., 20 (1966), 107-130. That viruses should be considered as viruses because they are viruses was also defended by James Moulder. He cited André Lwoff in a quotation from 1963: "Un gros virus est un virus. Une petite bactérie est une bactérie." See Moulder, "Psittacosis" (above), p. 107.

70. Thomas F. Anderson, "Electron Microscopy of Phages," in Cairns, Stent and Watson, Phage (above, n. 24), pp. 63-78, esp. p. 72. 
very time when the "modern concept of virus" was being formulated, there were already arguments which opposed the newly formed concept of virus. Nevertheless, the definition which was proposed by Lwoff is still nowadays the definition which functions to legitimize the existence of virology as an independent scientific domain. ${ }^{71}$

\section{Epilogue}

I have argued that the controversies from the 1920 s and 1940 s, which have been discussed in the preceding chapters, can be seen as conflicting research programmes where exogenous and endogenous interpretations of bacteriophage were confronted. However, the use of the concept of thought style as the connecting element for these different research programmes needs some further comment.

The first argument which legitimates the use of this term is the resemblance between the positions in the two controversies discussed. Secondly, the opposing positions had not only theoretical consquences but also resulted in "constraining forces" in relation to what had to be studied and how this was to be done in order to find meaningful answers within that particular research programme. ${ }^{72}$ Thirdly, the dichotomy between exogenous and endogenous thought styles structured the work of those who tried to transcend this division.

In the case of the controversies on the nature of bacteriophage I think it is justified to speak of thought styles because, to use Fleck's terminology, the Denkzwang ("thought constraint") was important for the meaning of concepts and the interpretation of experiments in a particular thought style. It is clear that the sociological dimensions of the controversies between the exogenous and endogenous thought styles within virus research and the usefulness of distinguishing these styles outside virus research needs further study. On the other hand, it is evident that this distinction has structured prolonged periods and broad domains in the history of virology in the twentieth century.

71. For a current definition of the category of viruses see, for instance, Roger Hull, Fred Brown and Chris Payne, Virology: Directory \& Dictionary of Animal, Bacterial and Plant Viruses (London: Macmillan, 1989), p. 240.

72. For a more explicit discussion of these constraining forces see Ton van Helvoort, "Bacteriological and Physiological Research Styles in the Early Controversy on the Nature of the Bacteriophage Phenomenon," Med. Hist., 36 (1992), 243-270 and idem, "The Controversy between John H. Northrop and Max Delbrück on the Formation of Bacteriophage: Bacterial Synthesis or Autonomous Multiplication?," Ann. Sci., 49 (1992), 545-575. These papers are included in the present study as Chapters 4 and 5, respectively. 



\section{CHAPTER 7}

\section{Controversies and the Formation of Consensus: Conceptual Continuity through Discontinuity}

CONTENTS

7.1 Research styles in virus studies $\mathbf{1 8 0}$

7.2 The concept of 'filterable virus':

an anomaly to the bacteriological paradigm? 184

7.3 The deconstruction of the 'unity' amongst filterable viruses $\mathbf{1 8 7}$

7.4 The construction of the domain of 'virus diseases' 191

7.5 The 'modern concept of virus': from multiplication to replication 198

7.6 The 'modern concept of virus' and the history of virology 203

7.7 Conceptual continuity through discontinuity $\mathbf{2 0 7}$

Adapted from

'History of virus research in the 20th century: the problem of conceptual continuity', History of Science, accepted for publication. 


\section{CHAPTER 7 \\ Controversies and the Formation of Consensus: Conceptual Continuity through Discontinuity}

\subsection{RESEARCH STYLES IN VIRUS STUDIES}

Chapters 2-6 have analysed the development of virus research in the 20th century on the basis of five case studies. What is striking in the description of these cases is the presence of fundamental and protracted controversies on the nature of the virus concerned. The discussions between Stanley on the one hand and Bawden \& Pirie on the other, between d'Hérelle and Bordet as well as between Northrop and Delbrück have been described in detail and reveal extensive differences of opinion.

The case studies on bacteriophagy make it especially clear that the various positions can be classified on the basis of whether the 'virus' was interpreted as autonomous or as a product of the host cell. A division according to exogenous and endogenous thought styles results in a dichotomy which is relevant for sorting out the positions in bacteriophage research (see Chapters 4, 5 and 6). This antithesis can also be recognized in the research on tobacco mosaic virus, in the physicochemical approach of Stanley versus the biochemical approach of Bawden \& Pirie (see Chapter 2 ). On the other hand, the research on influenza seems to include only representatives working within the exogenous thought style (see Chapter 3 ). I have argued that the positions of the actors in these controversies were anchored in the disciplinary contexts from which they conducted their research. Thus, it is possible to distinguish bacteriological, physiological, genetic, physicochemical and ecological/evolutionary approaches in virus studies. ${ }^{1}$

Not only did each of these research styles express itself in theoretical interpretations, they were also interwoven with choices with regard to the objects of research, the research techniques applied, the models and metaphors which were thought to be relevant, etcetera. Each style showed a certain consistency in the concepts, experimental techniques and experimental materials it used, thus leading to a holistic interpretational scheme. Conflicting research styles had specific interpretations of the phenomena and experimental results, an example of which is given in Table 7.1 on the

1. In the description of the case studies the terms 'disciplinary approach' and 'research style' have been used interchangeably, but in this overview I prefer the term 'research style'. 
basis of the positions of Northrop and Delbrück (cf. Chapter 5).

TABLE 7.1: Contrasts between the research styles of John H. Northrop and Max Delbrïck with regard to bacteriophage research in the 1940 s in terms of experiments, experimental techniques and theoretical notions.

\begin{tabular}{|c|c|c|}
\hline & Northrop & Delbrüick \\
\hline Research style: & physiological/chemical; & bacteriological/genetic; \\
\hline Research problem: & protein synthesis; & $\begin{array}{l}\text { biological multiplication; } \\
\text { reproduction of genes; }\end{array}$ \\
\hline Why bacteriophage: & $\begin{array}{l}\text { by analogy with proteins, } \\
\text { enzymes, adaptive enzymes, } \\
\text { antibodies; }\end{array}$ & $\begin{array}{l}\text { a virus is the most simple } \\
\text { living organism; }\end{array}$ \\
\hline Research aims: & $\begin{array}{l}\text { isolation and characterization } \\
\text { of bacteriophage; demon- } \\
\text { stration of phage precursor; }\end{array}$ & $\begin{array}{l}\text { elucidation of the mechanism } \\
\text { of biological reproduction; }\end{array}$ \\
\hline Quantification: & $\begin{array}{l}\text { 'time method'; } \\
\text { quantification as } t_{\text {lysis }} \\
\text { (a rate constant); }\end{array}$ & $\begin{array}{l}\text { plaque technique (number of } \\
\text { infectious particles); characterized } \\
\text { by genetic markers (e.g., plaque } \\
\text { morphology. rate of lysis); }\end{array}$ \\
\hline Realisation of experiment: & $\begin{array}{l}\text { staphylococcus \& lysogenic } \\
\text { or non-lysogenic } \\
\text { B. megaterium and } \\
\text { matching bacteriophages; }\end{array}$ & $\begin{array}{l}\text { young dividing bacteria }(E . \text { coli) } \\
\text { and virulent phages (T-series); } \\
\text { no experiments with } \\
\text { lysogenic bacteria; }\end{array}$ \\
\hline $\begin{array}{c}\text { Conclusion from experi- } \\
\text { ment with } P \gg B \text { : }\end{array}$ & $\begin{array}{l}\text { lysis plays no role in the } \\
\text { production of bacteriophage; }\end{array}$ & $\begin{array}{l}\text { apparently two phenomena: } \\
\text { 'lysis-from-within' and } \\
\text { 'lysis-from-without' }\end{array}$ \\
\hline Attitude to lysogeny: & $\begin{array}{l}\text { lysogeny is a } \\
\text { valid phenomenon; }\end{array}$ & $\begin{array}{l}\text { distinction between 'apparent' } \\
\text { and 'true' lysogeny; the latter } \\
\text { has to be reinvestigated } \\
\text { before it can be accepted } \\
\text { as a valid observation. }\end{array}$ \\
\hline
\end{tabular}

Table 7.2 presents the positions of various researchers in relation to the specific research style within which they studied a particular 'virus disease'. A first distinction is made between endogenous and exogenous thought styles; the latter is divided into four specific research styles. It must be noted that the positions of some researchers who tried to bridge the antithesis between the exogenous and endogenous thought styles (e.g., the Wollmans and Lwoff) have not been included in the table. 
TABLE 7.2: Characterization of research styles in studies on tobacco mosaic disease, bacteriophagy and human influenza by leading researchers in the first half of the 20 th century.

\begin{tabular}{|c|c|c|c|c|c|}
\hline & \multirow{2}{*}{$\begin{array}{c}\text { endogenous* } \\
\text { physiological } \\
\text { /biochemical }\end{array}$} & \multicolumn{4}{|c|}{ exogenous } \\
\hline & & $\begin{array}{l}\text { physico- } \\
\text { chemical }\end{array}$ & bacteriological & genetic & $\begin{array}{l}\text { ecological/ } \\
\text { evolutionary }\end{array}$ \\
\hline $\begin{array}{l}\text { Tobacco } \\
\text { mosaic disease }\end{array}$ & $\begin{array}{l}\text { F.C. Bawden } \\
\text { \& N.W. Pirie } \\
\text { (from 1936) }\end{array}$ & $\begin{array}{c}\text { W.M. Stanley } \\
\text { (from 1935) }\end{array}$ & & & \\
\hline Bacteriophagy & $\begin{array}{c}\text { J. Bordet } \\
\text { (from 1920) } \\
\text { A.P. Krueger \& } \\
\text { J.H. Northrop } \\
\text { (from 1929) } \\
\text { S.S. Coben } \\
\text { (from 1944) }\end{array}$ & & $\begin{array}{l}\text { F. d'Hérelle } \\
\text { (from 1917) } \\
\text { M. Delbridck } \\
\text { \& S.E. Luria } \\
\text { (from } 1939 \\
\text { to 1945) }\end{array}$ & $\begin{array}{l}\text { M. Delbrïck } \\
\text { \& S.E. Luria } \\
\text { (from 1945) }\end{array}$ & $\begin{array}{l}\text { F.M. Burnet } \\
\text { (1929) }\end{array}$ \\
\hline $\begin{array}{l}\text { Human } \\
\text { influenza }\end{array}$ & & $\begin{array}{l}\text { W.M. Stanley } \\
\text { (from 1944) }\end{array}$ & $\begin{array}{l}\text { F.M. Burnet } \\
\quad(1936) \\
\text { L. Hoyle } \\
(1937-1947)\end{array}$ & . & $\begin{array}{l}\text { F.M. Burnet } \\
\text { (from } \pm 1940 \text { ) }\end{array}$ \\
\hline
\end{tabular}

* Not everyone within the endogenous research style used the term 'virus'.

It can be concluded especially from the analysis of controversies in the research on tobacco mosaic disease and bacteriophagy that adherence to a particular research style had far-reaching implications for the notion of the nature of viruses and virus disease. Researchers who worked within an endogenous research style refused to accept the standard view that a virus had to be seen as an exogenous and autonomous agent. As a case in point, Bawden and Pirie argued that it was probably not justified to regard tobacco mosaic virus as a specific molecular entity, and they defended the view that in the study of plant virus diseases all anomalous products were of interest (see Chapter 2). Furthermore, Bordet argued that bacteriophage could not be seen as a virus of bacteria (see Chapter 4) and Northrop concluded that virus research from the $1950 \mathrm{~s}$ had confirmed his idea that viruses could not be conceived of as cellular parasites (see Chapter 5). 
According to the historiography of virology, the development of virus research in the 20th century is characterized by the following landmarks: 'late 19th century bacteriology', the concept of 'filterable virus' and the 'modern concept of virus'.? However, the profound nature of the controversies in 20th century virus studies leads to the conclusion that these controversies have played a more important role than is apparent from traditional histories of virology.

As was already stated in the introductory chapter, neither the controversies nor the formation of consensus in virus research can be explained as a consequence of the existence of 'viruses' which were investigated from different points of view. Contrary to André Lwoff's thesis that viruses are viruses because they are 'viruses' and Waterson's recapitulation of the history of virology as "the story of the progressive unveiling of the nature of the virus particle", my study defends the position that the category of "viruses' is to be conceived of as constructed. ${ }^{3}$ Therefore, I have tried to describe the formation of consensus not as the consequence of the very nature of the virus (retrospectively seen) but as the result of negotiating processes between actors. Because of the fundamental nature of the controversies described, the conceptual continuity which was created in virus research in the 20 th century demands an explanation.

In this chapter I will argue that, despite the many controversies, conceptual continuity in virus research could be maintained because the category of 'viruses' was defined at two levels. At the first level, a 'virus' was defined on the basis of the various infectious particles (the entities), a definition which was used in the early decades of the 20 th century. On the other hand, viruses were also defined at the effect level, i.e., on the basis of their behaviour and the pathological effect they had on the host organism. The conceptual continuity which can be detected in the development of virus research in the 20th century was achieved, in my opinion, by alternately defining the concept of virus on the basis of the properties of the virus particle, then on the basis of the pathological effect and, later, again on the basis of the infectious entity.

Besides discussing the problem of the perception of conceptual continuity in virus research as the study of 'viruses', this chapter makes a comparison between the specific elements of the research styles as they emerge from the case studies. Further-

2. See, for instance, A. P. Waterson and L. Wilkinson, An introduction to the history of virology (Cambridge, 1978).

3. A. Lwoff, "The concept of virus: the third Marjory Stephenson memorial lecture", Journal of general microbiology, xvii (1957), 239-53; A. P. Waterson, "Aims, possibilities and objectives", in Waterson and Wilkinson, op. cit. (ref. 2), pp. ix-xiii, esp. p. xii. 
more, it describes those elements from the various research styles which contributed to the formation of the 'modern concept of virus'.

\subsection{THE CONCEPT OF 'FILTERABLE VIRUS': AN ANOMALY FOR THE BACTERIO- LOGICAL PARADIGM?}

In the development of the ideas on the nature of 'viruses' two important points of stabilization can be distinguished. The first occurred in the early 20 th century, while the second can be situated in the 1950s. As a consequence of the success of bacteriology in the second half of the 19th century, it was presumed that all infectious diseases were caused by living agents (microbes). In 1889 Louis Pasteur did not doubt that the 'virus' (in the wider sense) causing rabies had to be thought of as a living organism:

\footnotetext{
The microbe of rabies has not been isolated as yet, but, judging by analogy [to the microbe which causes anthrax in cattle], we must believe in its existence. To resume: every virus is a microbe. Although these beings are of infinite smallness, the conditions of their life and propagation are subject to the same general laws which regulate the birth and multiplication of the higher animal and vegetable beings. ${ }^{4}$
}

The discovery at the turn of the century of the ultrafilterability of certain agents causing infectious diseases formed an anomaly for the standard methods of bacteriology. For most scientists, however, this finding was no reason to dismiss the bacteriological paradigm which stated that infectious diseases were caused by organized microbes. In Chapter 2 we have seen that the Russian botanist Dmitri Ivanovski described the filterability of the etiological agent of tobacco mosaic disease in 1892 and defended the bacterial nature of the agent. An exception was the Dutch scientist Martinus W. Beijerinck, who concluded from the diffusion of the agent in agar that a virus with wholly unknown properties was involved. The concept of a contagium vivum fluidum suggested by Beijerinck combined the element of infectivity, known from bacteriology, with an element from chemistry, a position which fell outside the mainstream of science at that time and was probably shared by only a few.

In a short time, filtration through an ultrafilter would become a standard method for characterizing many infectious disease-causing agents. An early example was the virus which causes foot-and-mouth disease and was isolated by Friedrich Loeffler and Paul Frosch in $1898 .^{5}$ Besides their filterability, the light-microscopic invisibility of

4. L. Pasteur, "Rabies", New review, i (1889), 505-12 and 619-30, esp. p. 506.

5. F. Loeffler and P. Frosch, "Berichte der Kommission zur Erforschung der Maul- und 
these agents also functioned as a criterion for classifying agents in the new category. A third property of the filterable viruses was, however, more controversial and concerned the dependence of these agents on host cells for their growth.

In his study of tobacco mosaic virus Beijerinck claimed that this agent depended on plant cells for its multiplication. In 1903 Ivanovski reported the presence of so-called inclusion bodies in cells of infected tobacco plants, while similar structures had been observed by Guiseppe Guarnieri in vaccinia infected tissue in 1892. The presence of intracellular inclusion bodies in virus diseases was interpreted by many as evidence for the obligatory parasitism of such viruses. ${ }^{6}$ John M'Fadyean was probably the first to point to the dependence of filterable viruses on a host for their multiplication as a "character common to all the ultravisible organisms".?

For the definition of the concept of 'filterable virus' three criteria seemed to be available: filterability, invisibility and non-cultivability of the agents. Chapter 1 already stated that Thomas M. Rivers concluded on the basis of these three criteria that the Klauenseuche bei dem Institut für Infektionskrankheiten in Berlin", Centralblatt fir Bakteriologie, Parasitenkunde und Infektionskrankheiten, I. Abt, xxiii (1898), 371-91.

6. D. Iwanowski, "Über die Mosaikkrankheit der Tabakspflanze", Zeitschrift für Pflanzenkrankheiten, xiii (1903), 1-41; G. Guarnieri, "Richerche sulla patogenesi ed etiologia dell'infezioni vaccinica e variolosa", Archivio scientifico di medicina veterinaria, xvi (1892), 403-24, cited in Waterson and Wilkinson, op. cit. (ref. 2), p. 154. Cf. S. S. Hughes, The virus: a history of the concept (London, 1977), pp. 11-27. The role of inclusion bodies in virus diseases is discussed in, for instance, E. V. Cowdry, "The problem of intranuclear inclusions in virus diseases", Archives of pathology, xviii (1934), 527-42.

7. J. M'Fadyean, "The ultravisible viruses", Journal of comparative pathology and therapeutics, xxi (1908), 58-68, 168-75 and 232-42, esp. p. 241.

Some researchers interpreted such inclusion bodies as the filterable viruses themselves. On this basis, Stanislaus Prowazek created a category of disease-causing agents including the agents of pox, vaccinia, scarlet fever, rabies and fowl plague. According to Prowazek these agents all showed a pronounced form of parasitism, obtained new biological properties when they were transmitted to another host species (i.e., they underwent mutations), and caused different kinds of reactions in the various host organisms (e.g., allergy). Such disease-causing agents were thought to be cell parasites, inducing the cell to produce specific reaction products which came to surround the agent. Prowazek denoted these agents as Chlamydozoa, which is derived from the Greek 'chlamus' and means coat. He positioned them between protozoa and bacteria. See S. Prowazek, "Chlamydozoa: I. Zusammenfassende Übersicht", Archiv für Protistenkunde, x (1907), 336-58. Similar arguments prompted Benjamin Lipschütz to create the category of the Strongyloplasma from the Greek for 'round' and 'body'. See B. Lipschütz, "Über mikroskopisch sichtbare, filtrierbare Virusarten (über Strongyloplasmen)", Centralblatt für Bakteriologie, Parasitenkunde und Infektionskrankheiten, I. Abt, xlviii (1909), 77-90. 
group of filterable viruses had three types of host organisms, viz. animals, plants and bacteria. The notion that the filterable viruses were characterized by an obligatorily parasitic relationship to host cells was not shared by everyone, as is apparent from a quotation in Rivers' obituary. This stated that the "stubborn insistence" of Rivers to see this as a fundamental difference "did much to establish virology as a separate discipline and to foster the development of knowledge about the nature of viruses and viral infections". ${ }^{8}$ Apparently, Rivers' point of view gave rise to much opposition, and some bacteriologists held the opinion that in the long run it would be possible to overcome this problem. Others suggested that saprophytic counterparts of the filterable viruses could possibly be isolated if it became known how to recognize such invisible agents without their destructive effects on host cells. ${ }^{9}$

The origin of virus research from bacteriology is reflected in much of the terminology suggested for the filterable disease-causing agents in the first decades of the 20 th century, which were strongly influenced by an organismal interpretation (see Table 7.3, p. 187).

The starting point of research on filterable viruses at the turn of the century resided in the anomalies which such disease-causing agents formed for the bacteriological paradigm. However, the properties of filterability, invisibility and non-cultivability did not force researchers to depart from the core of the bacteriological paradigm, i.e., the micro-organismal nature of the causes of infectious diseases. Many maintained the existing consensus by interpreting filterable viruses as ultramicrobes.

The most common interpretation of the nature of filterable viruses belonged to what I call the bacteriological research style. Within this research style a filterable virus was conceived of as an ultramicrobe, i.e., a living, autonomous and exogenous entity. This agent was supposed to show a process of multiplication which was analogous to that in bacteria, in other words by a process of binary fission. Such a view of the nature of viruses was to be defended by the British bacteriologist Samuel P. Bedson until far into the 1950s. In 1930 he rejected the notion, defended by

8. F, L. Horsfall, Jr., "Thomas Milton Rivers, September 3, 1888-May 12, 1962", Biographical memoirs of the National Acadeny of Sciences, U.S.A., xxxviii (1965), 263-94, esp. pp. $270-1$.

9. Paul Fildes wrote that Frederick W. Twort (see Chapter 4) started from "the idea of pathogenic organisms being derived from 'wild' types existing in nature with different characters imposed on them by their environment". This idea became the 'skeleton' for practically the whole of Twort's subsequent work. See P. Fildes, "Frederick William Twort 1877-1950", Obituary notes of Fillows of the Royal Sociery, vii (1950-51), 505-17, esp. p. 506. 
TABLE 7.3: Terminology for viruses suggested in the period before 1940. Note on the one hand the influence of a bacteriological paradigm and the criteria of filterability and invisibility and on the other hand the influence of a chemical approach ${ }^{10}$

- terminology which is independent of the nature of the virus:

- contagium stricto sensu; active substance

- referring to invisibility:

- invisible microbe/invisible virus

- ultramicroscopical virus/microbe/germ/organism and ultravisible virus/germ

- ultravirus (short for ultramicroscopic virus); ultraorganism; ultramicrobe; ultragerm

- submicroscopic virus; subvisible virus; infravisible virus

- referring to filterability:

- filterable virus/microbe/germ/organism; strongyloplasma, borrelina, ultrafilterable virus virus stricto sensu

— referring to size:

- inframicrobe/infragenn and protobe

- referring to non-living, crystallizable:

- virus-protein.

Beijerinck that filterable viruses were "unorganized enzyme-like agents". By contrast, Bedson argued that it was doubtlessly more sensible "to start from the simpler and more obvious conception that these viruses are akin to bacteria than to evolve an ingenious hypothesis postulating a new form of life [Beijerinck's contagium vivum fluidum] and endeavour to make observed facts support it". He concluded that the available evidence strongly supported the view that "filterable viruses are bacterial in nature"." Within the bacteriological research style the parasitical relationship between a filterable virus and the host cell was interpreted as the cell providing certain growth factors required by the filterable virus for its multiplication.

\subsection{THE DECONSTRUCTION OF THE 'UNITY' AMONGST FILTERABLE VIRUSES}

On the basis of one or more of the three criteria, filterability, invisibility and noncultivability, many agents were isolated in infectious diseases of man, animal and

10. Adapted from E. Sergent, L. Parrot and R. Horrenberger. "Pour l'unification de la terminologie concernant les «contages, microbes invisibles, virus filtrables, virus, ultravirus, inframicrobes, etc.»", Bulletin de l'Institut Pasteur, xxxviii (1940), 385-95, esp. pp. 385-6.

11. S. P. Bedson, "Filterable viruses and practical medicine", British medical journal, ii (1930), 505-8, esp. p. 505. 
plant. However, at the very moment when a certain degree of consensus was reached about the relevance of these criteria as a basis for the concept of 'filterable virus', more and more studies started to question the uniformity of this category. The results of physicochemical and chemical studies led to the conclusion that the filterable viruses were a heterogeneous group.

Various types of filterable viruses each appeared to have a specific size, and together they covered a continuous distribution over a wide range. Some species of virus were only marginally smaller than the smallest bacteria, while other viruses were slightly bigger than molecules of hemoglobin. Furthermore, virus particles of a certain type were found to be all of exactly the same size, unlike bacteria of a particular species, which were found to vary in size. ${ }^{12}$

In addition, it was concluded from chemical and biochemical studies that the composition of the various types of filterable viruses varied greatly. Thus, as we have seen, tobacco mosaic virus was characterized as a specific (nucleo)protein (see Chapter 2) while the human influenza virus appeared to contain lipids. ${ }^{13}$ Around 1940 it was claimed that human influenza virus showed enzymatic activity (later characterized as a neuramidase) and also contained antigenic material originating from the host (see Chapter 3). ${ }^{14}$ But the fundamental differences observed between the

12. W. J. Elford, "A new series of graded collodion membranes suitable for general bacteriological use, especially in filterable virus studies", Journal of pathology and bacteriology, xxxiv (1931), 505-21; F. M. Burnet and C. H. Andrewes, "Über die Natur der filtrierbaren Vira", Zentralblatt für Bakteriologie, Parasitenkunde und Infektionskrankheiten, I. Abt., Orig., cxxx (1933), 16183; H. Bechhold, "Ferment oder Lebewesen?", Kolloid-Zeitschrift, lxvi (1934), 329-40 and idem, lxvii (1934), 66-79; W. M. Stanley, "Biochemistry and biophysics of viruses", in R. Doerr and C. Hallauer (eds), Handbuch der Virusforschung (Vienna, 1938), pp. 447-546.

13. See, for instance, R. M. Franklin, "The significance of lipids in animal viruses: an essay on virus multiplication", Progress in medical virology, iv (1962), 1-53.

14. In a 1977 review Jean Lindenmann suggested that the antigenic similarities between host cells and viruses which are grown in these hosts was not a very popular subject because the problem was difficult to approach and did not seem to yield spectacular results. However, this observation was important in the discussion about the autonomy of viruses: "In the early days, the presence of host antigens in viruses was a token for the presence of building blocks of host material, a point which must have played some role in the controversy surrounding the status of viruses as independent organisms." See J. Lindenmann, "Host antigens in enveloped RNA viruses", in G. Poste and G. L. Nicolson (eds), Virus infection and the cell surface (Amsterdam, 1977), pp. 291-329, esp. p. 291. The reception of this observation, which presented an anomaly to the notion that a virus was an independent organism, deserves further study. 
nature of plant viruses on the one hand and that of animal viruses on the other could have been a consequence of the isolation techniques used and would then have to be interpreted as 'artefacts'. The British plant virus researcher Bill Pirie concluded that "[i]f a plant virus exists with properties similar to those of the influenza viruses, it is very unlikely that it would have appeared in any of the leaf extracts [of virus infected plants] made by methods used so far". 15

It is remarkable that the heterogeneous character of the category of filterable viruses was not regarded as very disturbing. According to Thomas $\mathrm{M}$. Rivers, it was possible that the category of filterable viruses contained agents of such diverging nature as nucleoproteins and micro-organisms: “... some of the viruses may be minute, highly parasitic microorganisms, the midgets of the microbial world, capable of reproduction only within susceptible host cells; that others may represent forms of life more or less unfamiliar to us; and that still others may be fabrications of their host cells aided by the processes of autocatalysis". ${ }^{16}$ It is my claim that the heterogeneous make-up of the category of viruses did not affect the legitimacy of the virus category because 'viruses' were to be defined at another level.

The validity of two of the characteristic properties of the filterable viruses, filterability and invisibility, came under more and more severe criticism. It was already concluded in the early part of the 20th century that the filterability of these agents depended greatly on the filtration techniques used. In 1911 Robert Doerr argued that filtration experiments only had any meaning if they were performed along agreed criteria. The filtration method could only "zur Klassifikation von Mikroben verwendet werden, wenn sich alle Autoren (...) entschließen könnten, gewisse Regeln der Filtration zu benutzen". ${ }^{17}$ Furthermore, with the improvements in optical instrumental techniques it became possible to visualize the largest viruses using UV-microscopy ${ }^{18}$,

15. N. W. Pirie, "The viruses", Annual review of biochemistry, xv (1946), 573-92, esp. p. 575. In the mid-1950s it was claimed that a lytic enzyme (closely related to the bacteriolytic enzyme lysozyme, which was observed by Alexander Fleming in 1922) appeared to be attached to T2 phage particles. See G. S. Stent, Molecular biology of bacterial viruses (San Francisco, 1963), pp. 81-2.

16. T. M. Rivers, Lane medical lectures: viruses and virus diseases (London, 1939), p. 99.

17. R. Doerr, "Ueber filtrierbares Virus", Centralblatt für Bakteriologie, Parasitenkunde und Infektionskrankheiten, I. Abt., Ref., I (Beiheft) (1911), 12-23, esp. p. 17. For the technique of ultrafiltration see, for instance, W. J. Elford, "Ultrafiltration (an historical survey, with some remarks on membrane preparation technique)", Journal of the Royal Microscopical Society, xlviii (1928), 3645; R. R. Hyde and R. E. Gardner, Laboratory outline in filterable viruses (New York, 1937).

18. See, for instance, C. Beck, J. E. Barnard, et al., "Discussion on the microscopy of the filterable viruses", Joumal of the Royal Microscopical Society, lii (1932), 230-45. 
and in 1939 the first electron microscopic pictures of viruses were published. ${ }^{19}$ As the relevance of criteria like filterability and invisibility became a subject of debate, the importance of the criterion of the non-cultivability of filterable viruses on inert nutrient media increased. Moreover, the confidence in a technical solution to the problem of culturing viruses in inert media was found to be idle and cell and tissue culture techniques were developed to overcome the dependence on host organisms. ${ }^{20}$

But it was not only the nature of the various species of virus which seemed to vary. In the case studies we have seen that even for one and the same virus disease researchers came to wholly different conclusions regarding the nature of the etiological agent. In Chapter 2 we have seen that tobacco mosaic virus was conceived of as a living molecule (Beijerinck), an ultramicrobe (Allard), a gene (Duggar \& Karrer Armstrong), or a chemical molecule (Stanley), and it was even doubted whether a virus could be characterized as a single entity (Bawden \& Pirie). It can be concluded from the case studies that the concept of 'filterable virus' was also deconstructed because two opposing thought styles developed. Within the first thought style, a virus was interpreted as an exogenous and autonomous agent, while the other thought style developed the view that a filterable virus was of endogenous origin. Within the exogenous thought style it was assumed that a virus was an ultramicrobe, a macromolecule, or a gene. The endogenous interpretation explained a virus disease in terms of the physiology of the host cell, the virus being a product of that cell.

The distinction of two contrasting thought styles in virus research finds a justification in the similarity of approach across the individual case studies within the endogenous and exogenous research styles. There are important similarities in the exogenous research styles with regard to tobacco mosaic disease, human influenza and bacteriophagy, which can be summarized as an exogenous thought style. Likewise,

19. G. A. Kausche, E. Pfankuch and H. Ruska, "Die Sichtbarmachung von pflanzlichem Virus im Übermikroskop", Naturwissenschaften, xxvii (1939), 292-9; H. Ruska and G. A. Kausche, "Ueber Form, Größenverteilung und Struktur einiger Virus-Elementarkörper", Zentralblatt für Bakteriologie, Parasitenkunde und Infektionskrankheiten, I. Abt., Orig., cl (1943), 311-8. Cf. R. C. Williams, "Electron microscopy of viruses", Advances in virus research, ii (1954), 183-239.

20. See F. C. Robbins and J. F. Enders, "Tissue culture techniques in the study of animal viruses", American journal of medical sciences, ccxx (1950), 316-38; G. O. Gey and F. B. Bang, "Viruses and cells - a study in tissue culture applications. 1. Cells involved - availability and susceptibility", Transactions of the New York Academy of Sciences, xiv (1951), 15-24. Cf. "Development of cell and tissue culture", in Waterson and Wilkinson, op. cit. (ref. 2), pp. 67-77; E. N. Willmer, "One man's view of cell biology in Cambridge in the 1930s", Trends in biochemical sciences, xiv (1989), 193-5. 
the endogenous research styles in the research on tobacco mosaic disease and bacteriophagy show essential similarities, which can be designated as an endogenous thought style. Table 7.4 (see p. 192) summarizes the explanations offered by the two opposing thought styles in virus research for a large number of observations.

It can be concluded that in the third and fourth decades of this century a deconstruction of the concept of 'filterable virus' took place. Firstly, it was realized that the criteria of filterability and invisibility depended on the methods used; this encouraged the use of the criterion of non-cultivability for the identification of viruses. Secondly, the category of 'filterable viruses' appeared to consist of heterogeneous elements. This was based primarily upon the results of physicochemical and chemical studies. A tendency toward deconstruction arose when the bacteriological paradigm, which had nourished the concept of 'filterable virus', came to be criticized from the point of view of the physicochemical research style and the endogenous interpretations.

\subsection{THE CONSTRUCTION OF THE DOMAIN OF 'VIRUS DISEASES'}

It has already been mentioned that Thomas M. Rivers admitted that the category of the 'filterable viruses' consisted of heterogeneous entities, which was confirmed by Samuel Bedson in the 1950s: "Where is one to draw the line which is to separate the microbial midgets from the unorganised, non-living, autocatalytic infective agents? It is impossible to say because, from the very smallest up to the largest virus, there is an unbroken series, not only of particle size, but also of complexity of structure; one merges into the next with no clear indication of a gap suggesting division of the group."21 The heterogeneousness of the category of viruses was regarded by Rivers in 1941 as non-problematic: "From a practical standpoint it makes little difference at the present time whether a virus is an inanimate crystalline protein or a minute obligate parasite." 22 And in the essay by Bedson quoted above, the latter stated that the common element of these disease-causing agents could be found at the level of the disease: "there is no fundamental difference in the clinical and epidemiological behaviour of the diseases caused by these viruses which might lead one to think that

21. S. P. Bedson, "Viruses: some general considerations", in S. P. Bedson, A. W. Downie, F. O. MacCallum and C. H. Stuart-Harris, Virus and rickettsial diseases (London, 1950), pp. 1-21, esp. pp. 18-19. Bedson's contribution was reprinted largely unaltered in the second edition of this book (1955)

22. T. M. Rivers, "Virus infections", Bulletin of the New York Academy of Medicine, xvii (1941), 245-58, esp. p. 257. 
TABLE 7.4: The properties of a 'virus' explained in terms of exogenous and endogenous thought styles as these existed in the research on tobacco mosaic disease, human influenza and bacteriophagy in the first half of the 20 th century.

\section{OBSERVATION}

Nature of the principle:

Infectiousness:

Multiplication:

Emphasis on:

Relationship to host:

Host dependence

explained by:

Characteristics of 'life':

Pathological effect

(virus disease):

Filterability and light-

microscopic invisibility.

Non-cultivability:

Stability and reaction to

chemicals, temp., eic.:

Spontaneous appearance

$$
\text { of (virus) disease: }
$$

Evolutionary

origin of the virus:

Ecological behaviour:
VIRUS AS EXOGENOUS

MICROBIAL AGENT*

living organism;

inherent property

of infectious agent;

inherent property

of 'life';

quality of the virus;

exogenous; autonomous;

obligatory parasitism; host

provides e.8., 'growth factors';

preservation of individuality;

adaptation; mutation;

assimilation (metabolism);

result of the multi-

plication of the virus;

ultramicrobe; complex;

organised;

technical problem(?); existence

of saprophytic filterable

viruses was to be expected;

characteristic of living

organism;

impossible: there is no 'spontanous generation' of microbes;

retrograde evolution;

part of the host cell;

behaviour as organism;

\section{'VIRUS' AS \\ ENDOGENOUS PRODUCT ${ }^{\dagger}$}

lifeless chemical principle; no natural infectivity

but artificial infectivity;

analogous to autocatalysis

and crystal growth;

quantity of the principle;

endogenous;

product of the host;

not applicable;

disturbance of host

metabolism;

simple; comparison with antigens

and antibodies; chemical substance,

e.g., protein or colloid;

inherent property of

a chemical product;

characteristic of lifeless

chemical product;

confirms endogenous origin;

not applicable;

not applicable.

* In addition to the bacteriological research style, the exogenous thought style also included a physicochemical research style as an important alternative. In this view a virus was conceived of as a chemical macromolecule.

+ Within the endogenous research style not everyone adhered to the view that the object of research was a 'virus'. Instead, researchers spoke, for instance, of 'bacteriophage' as a 'lytic principle'. 
some viruses were of an essentially different nature from others". Bedson ended his essay with the conclusion that "whatever future research may reveal, for all practical purposes viruses behave as though they were micro-organisms". 23 The thesis which is defended in this chapter is that in spite of the deconstruction of the concept of 'filterable virus', conceptual continuity in the form of a scientific domain of virus studies could be maintained because the common properties of the filterable viruses were sought for at the level of the behaviour of viruses and especially in their pathological effects. This concerned pathological, epidemiological and ecological properties of the viruses, i.e. not the properties of the infectious entities but their effects. In spite of the heterogeneous composition of the category of 'filterable viruses' and the controversies on the nature of the viruses, the concept of virus could be used to stake out a certain domain of research. The many books on viruses and virus diseases which appeared in the 1930 s bear witness to the consensus regarding the existence of a conceptual category of 'viruses' ${ }^{24}$

In the 1930s and 1940s the criterion for virus diseases was not based purely on the presence of a filterable virus particle as the etiological agent, as is clear from two examples taken from the case studies. It was argued in Chapter 2 that the respective conceptions of Stanley and Bawden \& Pirie with regard to tobacco mosaic virus differed greatly. At the end of that chapter it was concluded that these parties had a common basis for discussion because they agreed that they both studied tobacco mosaic disease. This constituted the basis on which the controversy was founded. A second example can be found in Chapter 4, where the discussion between d'Hérelle and Bordet about the nature of bacteriophage was possible because these two scientists agreed that at the level of the 'bacteriophage phenomenon' - i.e., the lysis of

23. Bedson, op. cit. (ref. 21), pp. 19-20.

24. After the publication of Filterable viruses in 1928, edited by Thomas M. Rivers, the 1930s saw many monographs relating to virus research: C. H. Andrewes, J. Arkwright, et al., A system of bacteriology in relation to medicine; vol. vii [virus diseases] (London, 1930); A.-D. Gardner, Microbes and ultramicrobes (London, 1931); R. W. Fairbrother, Handbook of filterable viruses (London, 1934); K. M. Smith, Plant viruses (London, 1935); Hyde and Gardner, op. cit. (ref. 17); P. P. Laidlaw, Virus diseases and viruses (Cambridge, 1938); R. Bieling, Viruskrankheiten des Menschen, ihre Erreger und ihre Bekämpfung (Leipzig, 1938); C. Levaditi, P. Lépine et al., Les ultravirus des maladies humaines (Paris, 1938); Doerr and Hallauer, op. cit. (ref. 12); Rivers, op. cit. (ref. 16); E. Gildemeister, E. Haagen and O. Waldmann (eds), Handbuch der Viruskrankheiten mit besonderer Berücksichtigung ihrer experimentellen Erforschung (Jena, 1939); F. C. Bawden, Plant viruses and virus diseases (Leiden, 1939). 
bacteria - they were studying a common research object. But they clashed heavily, as we have seen, on the nature of the phenomenon.

An example of the transition from a definition of a virus based on its pathological effect to one based on the properties of the virus particle, which occurred in the $1950 \mathrm{~s}$, was the research on fowl plague virus and Newcastle disease virus (atypical fowl plague). These agents were first conceived of as different viruses on the basis of the symptoms of these virus diseases in fowls. Later on this was confirmed by Macfarlane Burnet on the basis of the pathological effect of these viruses on the chick embryo. In the 1950s it was concluded from chemical analyses of the virus particles that both cases involved one of the influenza viruses which, as a group, would come to be designated as myxoviruses (see Chapter 3 ). ${ }^{25}$

That the validity of the category of 'viruses' was not self-evident in the 1930s and 1940 s can be illustrated by the discussions about the similarities and dissimilarities between the phenomena of viral interference between different types of bacteriophages, plant viruses or animal viruses. Viral interference is the observation that when a host organism has recovered from a first viral infection, it reacts differently to infection with a second virus - whether related to the first virus or not. The reason for discussing the results of some of the studies of viral interference phenomena is that the viruses were not described as infectious particles but at their effect level. One of the points which was regularly discussed in the study of viral interference was the extent to which resemblances could be recognized between the various main groups of viruses, i.e., bacterial, plant and animal viruses. It must be remembered that my basic point was that the concept of virus is not to be seen as a natural category of infectious agents of animals, plants and bacteria but as a hypothesis which needed to be founded and whose validity was tested continuously.

In his 1932 Harvey Lecture Louis Kunkel discussed the similarities and differences between infectious diseases in plants and animals. He concluded that there were important analogies between virus diseases in plants and virus diseases in animals. He claimed that the "intracellular pathology of plant virus diseases is remarkably like that of animal virus diseases in respect to the occurrence and development of inclusion bodies". And although many, according to Kunkel, held the opinion that there was a fundamental difference between the immunity incited by a virus in an

25. F. M. Burnet and J. D. Ferry, "The differentiation of the viruses of fowl plague and Newcastle disease: experiments using the technique of chorio-allantoic membrane inoculation of the developing egg", British journal of experimental pathology, xv (1934), 56-64; C. H. Andrewes, F. B. Bang and F. M. Burnet. "A short description of the Myxovirus group (influenza and related viruses)", Virology, i (1955), 176-84. 
animal and that invoked in a plant, he concluded that this was a mistaken belief. A plant too could show 'acquired immunity' (e.g., to ring spot in Nicotiana), the only difference with immunity in animals being that "retention of the causal agent" was observed in plants which had recovered from an infection. ${ }^{26}$ The phenomenon of the 'acquired immunity' of a plant against one or more viruses aroused great interest in the 1930 s. We will see that these observations were interpreted on the basis of the notion that a virus was exogenous and that the host cell provided one or more growth factors.

William C. Price, an expert in this field, was to claim in the 1940 s that the confirmation that 'acquired immunity' could be observed in plants as well as animals was a strong argument in favour of an analogy between virus diseases in these different host organisms. The fact that a plant which was immune against a particular virus showed no antibodies did not necessarily imply a distinction between acquired immunity in plant and animal virus diseases. The similarities between virus diseases of bacteria, plants and animals, as studied by means of viral interference, appeared to lie at the level of virus multiplication in the host cell. According to the hypothesis which Price articulated to explain viral interference, this phenomenon was closely related to the dependence of viruses on the host cell:

[C]ertain protoplasmic constituents, such as, perhaps, specific amino acids, are essential for virus reproduction. It is conceivable that one virus in a plant may exhaust the supply of material essential for reproduction of that particular virus and thus render the invaded cell immune from a closely related virus that requires the same material. Other unrelated viruses, however, might require entirely different materials which would not be utilized by the first vinus. The cell would, therefore, still be just as susceptible as a virus-free one. ${ }^{27}$

It will be clear that this 'exhaustion hypothesis' (my term) for the mechanism of viral interference was closely affiliated to the notion of viruses which existed within the exogenous bacteriological research style and which has been described in the case studies (e.g., the 'Laidlaw-Green hypothesis' on the nature of viruses discussed in Chapter 3).

The 'exhaustion hypothesis' also played a key part in explaining the viral interference observed in virus infections in animals or animal tissues. In 1942, Christopher

26. L. O. Kunkel, "Similarities between the diseases of the vegetable kingdom and those of man and animals [Lecture delivered on 17 November 1932.]", Harvey lectures, xxviii (1934), 56-66, esp. pp. $62-4$.

27. W. C. Price, "Acquired immunity from plant virus diseases", Quarterly review of biology, xv (1940), 338-61, esp. p. 355. 
H. Andrewes wrote that the phenomenon of viral interference observed between biologically distinguishable influenza- $A$ viruses could be explained as a consequence of the hypothesis that the first virus "uses up some essential foodstuff in the cells". By contrast, the absence of viral interference between, for instance, the viruses of influenza and lymphogranuloma venereum could be explained from "a biochemical difference in their demands upon a cell for food or by a difference in the type of cell attacked", ${ }^{28}$ The explanation which Max Delbrück and Salvador E. Luria formulated for the interference between non-related bacteriophages did not involve the concept of a limited supply of a certain substance. These authors assumed the involvement of a 'key enzyme' in the growth of both bacterial viruses, as a result of which the second virus could not multiply. ${ }^{29}$ Shortly afterwards, Delbrück and Luria would abandon the 'key enzyme hypothesis' in favour of the 'penetration hypothesis' (see Chapter 5).

Delbrück adhered to viral interference as an important argument for classifying bacteriophage as a bacterial virus. In a sequel to his earlier studies, he concluded in 1945 that the "occurrence of the [interference] phenomenon with plant, animal, and bacterial hosts indicates that we are dealing with an aspect of the relation between viruses and their host cells of universal validity. It would seem that any real progress in our understanding of this phenomenon for one group of viruses should teach us something about all viruses." 30 It is in this context that we should view Thomas $F$. Anderson's claim that many of the members of the 'Phage Group' were involved in "a plot to interest the 'real plant and animal virologists' in bacteriophages by calling them 'bacterial viruses'." 31

Observations on viral interference also played an important part in the book Viruses 1050 , edited by Max Delbrück. ${ }^{32}$ In this book - with its revealing subtitle

28. C. H. Andrewes, "Interference by one virus with the growth of another in tissue-culture", British journal of experimental pathology, xxiii (1942), 214-20, esp. p. 219.

29. M. Delbrück and S. E. Luria, "Interference between bacterial viruses: I. Interference between two bacterial viruses acting upon the same host, and the mechanism of virus growth", Archives of biochemistry, i (1942), 111-41; S. E. Luria and M. Delbrück, "Interference between inactivated bacterial virus and active virus of the same strain and of a different strain", idem, i (1942), 207-18.

30. M. Delbrück, "Interference between bacterial viruses: $M$. The mutual exclusion effect and the depressor effect", Journal of bacteriology, l (1945), 151-70, esp. p. 151.

31. T. F. Anderson, "Electron microscopy of phages", in J. Cairns, G. S. Stent and J. D. Watson (eds), Phage and the origins of molecular biology (Cold Spring Harbor, 1966), pp. 63-78, esp. p. 72 .

32. M. Delbrück (ed.) Viruses 1950: proceedings of a conference on the similarities and dissimilarities between viruses attacking animals, plants, and bacteria, respectively (Pasadena, 1950). 
Proceedings of a conference on the similarities and dissimilarities between viruses attacking animals, plants, and bacteria, respectively - Frederick C. Bawden discussed the differences between the 'protection phenomenon' observed in plants and the phenomenon of 'mutual exclusion' of bacteriophage in multiple infections. In the latter case, the multiplication of a non-related second bacterial virus was totally inhibited by a first, interfering virus. Bawden concluded that there were important differences between plant viruses and bacterial viruses with regard to interference between non-related viruses: "There is nothing known with plant viruses that is exactly comparable with the mutual exclusion phenomenon. Various kinds of interactions are known between different plant viruses, but there are no pairs known in which infection with one precludes infection with another." 33 Max Delbrück, however, thought the absence of 'mutual exclusion' in plant viruses not convincingly proved, because the interference experiments which were done with plants corresponded "to mixed infections of whole bacterial cultures with two unrelated viruses. From such experiments mutual exclusion could never have been inferred, since in whole cultures some cells will yield one virus, some the other, thus obscuring the mutual exclusion phenomenon which concerns the individual cell." 34 (Italics in the original.) With respect to related viruses Delbrück concluded that both bacteria and plants showed viral interference, which could best be explained in terms of a competition for intracellular material which was available in limited amounts. However, it was not yet known whether this material was of "the nature of building material for the virus or of the nature of equipment necessary for the synthesis of the virus". ${ }^{35}$ (Italics in the original.)

To R. W. Schlesinger it seemed unlikely that 'mutual exclusion' would be the rule in animal viruses. He concluded this from the observation that one single animal cell could be infected with two non-related viruses. Examples of this included virusinfected cells which showed intra-nuclear as well as intra-cytoplasmatic inclusion bodies at the same time, each of which were typical of a different virus. ${ }^{36}$

33. F. C. Bawden, "Interference phenomena with plant and bacterial viruses", in Delbrück, op. cit. (ref. 32), pp. 30-2, esp. p. 31.

34. M. Delbrück, "Comment", in Delbrück, op. cit. (ref. 32), pp. 32-4, esp. p. 33.

35. Delbrück, op. cit. (ref. 34), p. 32.

36. See R. W. Schlesinger, "Interference between animal-pathogenic viruses", in Delbruick, op. cit. (ref. 32), pp. 68-78, esp. pp. 69-70. Schlesinger referred to K. Anderson, "Dual virus infections of single cells", American joumal of pathology, xviii (1942), 577-83 and J. T. Syverton and G. P. Berry, "Multiple virus infection of single host cells", Journal of experimental medicine, Ixxxvi 
In this section I have made a first attempt to show that the deconstruction of the concept, or category, of 'filterable virus' was reversed by processes of construction which attempted to create a new unity of similarities and dissimilarities at the level of 'virus diseases'. We have seen that both Rivers and Bedson argued that viruses could be regarded as one category because of their typical behaviour. Striking examples of the preservation of the concept of 'virus' can be found in the positions of Kunkel, Price and Delbrück. In their research on viral interference, viruses were studied at their effect level, e.g. with regard to inclusion bodies, pathological effects or host range. The study of this phenomenon was used to evaluate the relationships between the main groups of viruses, viz, bacterial, plant and animal viruses.

\subsection{THE 'MODERN CONCEPT OF VIRUS': FROM MULTIPLICATION TO REPLICATION}

The second half of the 1940s saw the start of the development which was to lead to a new conception of the multiplication of viruses. The terms virus growth and virus multiplication formed a relict from the origin of virus research, i.e., bacteriology. The replacement of these terms by the terminology of virus reproduction or virus replication was symbolic for the emancipation of virus researchers from that origin. ${ }^{37}$ This was in large measure a result of bacteriophage research.

At the end of the 1940s there was, according to Thomas M. Rivers, not only consensus that bacteriophage had to be conceived of as bacterial virus but "many virologists were also beginning to use it as a key in the elucidation of virus-host systems". ${ }^{38}$ At that time, August H. Doermann claimed that during its multiplication (growth) the bacteriophage particle went through an eclipse and thus 'disappeared' as an infectious particle (see Chapter 6). ${ }^{39}$ As was described in Chapter 3, a similar (1947), 145-52.

37. See, for instance, F. M. Burnet, "Mathison memorial lectures: virology as an independent science", Medical joumal of Australia, xl (1953), 841-5. In the article in which the one-step-growth technique for the study of phage multiplication was explained, Ellis and Delbrück used the term 'growth' for the increase of bacteriophage particles. See E. L. Ellis and M. Delbrück. "The growth of bacteriophage", Journal of general physiology, xxii (1939), 365-84.

38. S. Benison, Tom Rivers: reflections on a life in medicine and science (Cambridge, Mass., 1967), p. 438. Even by then there was still a small minority of researchers who rejected the view that bacteriophages were bacterial viruses. An example was Arthur Felix who "to his death in 1956 (...) maintained that phages were enzymes produced by the host bacteria, not viruses." See R. E. O. Williams, Microbiology for the public health (London, 1985), p. 47.

39. A. H. Doermann, "Intracellular growth of bacteriophage", Carnegie Institution of Washington yearbook, xlvii (1948), 176-82; see Stent, op. cit. (ref. 15), pp. 83-7. Cf. A. H. 
claim in relation to the multiplication process of influenza virus by Leslie Hoyle was only gradually accepted, which is not surprising if we keep in mind the strong consensus in favour of the bacteriological research style which existed in the study of animal viruses. With the replacement of the concept of virus multiplication with virus replication, independence of virus research was claimed and finally became accepted. Hoyle wrote that when the concept of binary fission was rejected for the animal viruses, "the study of viruses was no longer regarded as a branch of bacteriology, the similarity of plant, animal and bacterial viruses was established, and virology had become a science on its own right". 40

It is striking that the implicit presupposition that viruses multiplied in the same way as bacteria was only made explicit in the literature of virus research when its validity was being challenged. In the early 1950s the concept of 'binary fission' in relation to virus reproduction suddenly appeared in many articles. In 1953 Macfarlane Burnet wrote that it had become clear that "viruses like influenza do not multiply by binary fission", and this claim formed a starting point for his textbook on animal viruses, which was published two years later. ${ }^{41}$ At the end of the the 1950 s, the British pathologist Michael Stoker wrote that there were still doubts about the way viruses multiplied, but nobody had ever proved that "any virus proper" multiplied by binary fission and there was "a good deal of evidence to the contrary, although this [was] the subject of some controversy". 42

In the 1950s the existence of an eclipse in virus multiplication was not to be accepted without debate. It was argued that the experimental results of the study of virus multiplication could also be interpreted in a different way if one took the differences in the sensitivity of the experimental methods into account (see Chapter 3). ${ }^{43}$ In the early 1950s, according to Alfred Hershey (see Chapter 6), some virus researchers defended an interpretation in which bacterial viruses were regarded as microbes and Doermann, "Introduction to the early years of bacteriophage T4", in C. K. Mathews, E. M. Kutter, G. Mosig and P. B. Berget, Bacteriophage T4 (Washington, D.C., 1983), pp. 1.7.

40. L. Hoyle, The influenza viruses; virology monographs vol. 4 (Vienna, 1968), p. 15. Cf. L. Hoyle, "The growth cycle of influenza virus A: a study of the relations between virus, soluble antigen and host cell in fertile eggs inoculated with influenza virus", British joumal of experimental pathology, xxix (1948), 390-9.

41. Burnet, op. cit. (ref. 37), p. 843. See also F. M. Burnet, Principles of animal virology' (New York, 1955).

42. M. G. P. Stoker, "The growth of viruses", in Lectures on the scientific basis of medicine; vol. VII: 1957-58 (London, 1959), pp. 223-8, esp. p. 225.

43. F. Fuiton, "Growth-cycle of influenza virus", Nature, clxiv (1949), 189-90. 
the observed eclipse was explained "by analogy with other parasites". It could be supposed that the infecting bacterial virus particle underwent "minimal modifications (softening of surface structures, loss of ability to survive in the naked state, elaboration of enzymes) preparatory to growth in size and multiplication by fission". ${ }^{44}$ As was shown above, Samuel P. Bedson maintained as late as the 1950 s that viruses could best be interpreted as ultramicrobes. He also defended this view in his Panton memorial lecture, held in 1955, where he discussed not only the research on psittacosis, in which he was heavily involved, but also the results of recent research on bacteriophage and influenza virus. ${ }^{45}$ In the end, consensus on the process of virus multiplication was formed by eliminating organisms which multiplied by binary fission, such as 'psittacosis-virus' (a chlamydozoa), from the category of 'viruses' (cf. Chapter 6).

Besides the replacement of the concept of virus multiplication by virus replication there was a second argument which was to become one of the basics of the 'modern concept of virus'. In the 1950 s it became common usage to talk about the genetic information of a virus (its genome). A clear example can be found in Salvador Luria's essay on virus reproduction (i.e., bacterial virus reproduction) from 1950.46 Furthermore, it became accepted that the hereditary information of an organism was encoded solely in the nucleic acid of the organism. The slow acceptation of the role of nucleic acid (see also Chapter 2) appears, for instance, from the following quotation from 1953, in which Burnet concluded on the basis of his genetic research on influenza viruses that this virus could be divided into a somatic and a genetic part, called the soma and the genome:

The surface characters of the virus, its immunological nature, its absorptive haemagglutinating and enzyme-like activities are somatic, and they are the only static qualities by which the existence of virus can be recognized. The genome has as yet no detectable qualities by which its presence can be recognized, short of testing the power of the virus to multiply. The possibility that its physical basis is the $1 \%$ of nucleic acid (almost wholly RNA) present in the virus particle is likely enough but has not been established. ${ }^{47}$

44. A. D. Hershey, "Bacteriophage T2: parasite or organelle? [Lecture delivered on 26 April 1956.]", Harvey lectures, li (1957), 229-39, esp. p. 231.

45. S. P. Bedson, "The Panton memorial lecture for 1955: the mode of virus multiplication and the susceptibility of these agents to the antibiotics", Joumal of clinical pathology, ix (1956), 83-93.

46. S. E. Luria, "Bacteriophage: an essay on virus reproduction", Science, cxi (1950), 507-11; reprinted in Delbrück, op. cit. (ref. 32), pp. 7-15.

47. Burnet, op. cir (ref. 37), p. 843 
In Chapter 6 I have shown that Luria was to become an especially ardent defender of the notion that a virus infection had to be seen as the 'taking over' of the control of the metabolism of the host cell by the genetic information of the virus. The definition of a virus as a genome contributed to the establishment of the concept of multicomponent viruses (see Chapter 2). As was described in the previous chapter, research by André Lwoff et al. on lysogenic bacteria resulted around 1950 in new concepts for the 'life cycle' of a virus, such as 'vegetative virus' and 'provirus', and in 1959 it was proposed to use the word 'virion' for the infectious virus particle. ${ }^{48}$

Thus, the 'modern concept of virus' was the result of a number of simultaneous developments. In the first place, the acceptation of the claim that viruses do not reproduce by binary fission, which was concluded from the fact that a virus particle appeared to go through an eclipse; secondly, the acceptation of the claim that the hereditary information of viruses is encoded in their nucleic acid; thirdly, the proposition of the concept of 'provirus' on the basis of research on lysogenic bacteria; fourthly, the elimination of specific infectious agents such as chlamydozoa, which multiply by binary fission, from the category of viruses.

Table 7.4 (p. 192) showed that virus research in the first half of the 20th century involved a number of fundamental observations and problems, to which the exogenous and the endogenous thought styles formulated specific answers. Table 7.5 (p. 202) summarizes the explanations which could be formulated to answer the same observations and problems after the 'modern concept of virus' had been accepted.

The 'modern concept of virus' was able to link a number of crucial elements and findings, belonging to various research styles. A number of cognitive contributions to the 'modern concept of virus' originating from the various research styles are summarized in Table 7.6 (p. 203).

In Chapter 4 and Chapter 5, respectively, it was shown that Jules Bordet and John H. Northrop, who were working in the endogenous thought style, refused to see bacteriophage as a virus. Therefore, the incorporation of the findings of the endogenous research style into the 'modern concept of virus' meant a reinterpretation of the history of virus research. A whole domain of research, which initially appeared to belong to the biochemistry and physiology of the host cell, was reinterpreted with the acceptation of the 'modern concept of virus' and came to be regarded as belonging to the history of virus research.

48. Lwoff, op. cit. (ref. 3); A. Lwoff, T. F. Anderson and F. Jacob, "Remarques sur les charactéristiques de la particule virale infectieuse", Annales de l'Institut Pasteur, xcvii (1959), 281-9. 
TABLE 7.5: Observations about virus diseases and the properties of viruses from the first half of the 20 th century as explained in terms of the 'modern concept of virus'.

\section{THE 'MODERN CONCEPT OF VIRUS'}

\section{OBSERVATION}

Nature of the principle:

Infectivity:

Multiplication:

Relationship with the host:

Host dependence explained by:

Characteristics of 'life':

Pathologic effect (virus disease):

Filterability and light. microscopic invisibility:

Non-cultivability:

Stability and reaction to chemicals, temperature, etc.:

Spontaneous appearance of disease:

Evolutionary

origin of the virus:

Ecological behaviour:

virus as nucleic acid (carrier of genetic information) surrounded by a coat of protein; property of the virion; property of the vegetative phase of the virion;

a virion is autonomous; the virus genome can be picked up in the host genome; the 'coat' of the virion can contain substances (antigens) of the host; the virus genome takes over the metabolic machinery of the host cell (genetic parasitism); replication; preservation of individuality; mutation; disturbance of host metabolism; size of the virion;

a virion does not contain enzymes for biosynthesis; the virus is dependent on the Lipmann system of the host cell; properties of the virion;

the virus genome can be present in latent form; retrograde evolution; part of the genetic material of the host cell; similar to micro-organisms. 
TABLE 7.6: Selection of contributions of the various research styles to the 'modern concept of virus', divided into the three 'phases of life' of a virus.

\begin{tabular}{|c|c|c|c|c|c|}
\hline & \multirow{2}{*}{$\begin{array}{l}\text { endogenous } \\
\text { physiological } \\
\text { /biochemical }\end{array}$} & \multicolumn{4}{|c|}{ exogenous } \\
\hline & & $\begin{array}{l}\text { physico- } \\
\text { chemical }\end{array}$ & bacteriological & genetic & $\begin{array}{l}\text { ecological/ } \\
\text { evolutionary }\end{array}$ \\
\hline VIRION & $\begin{array}{l}\text { result of host } \\
\text { metabolism; }\end{array}$ & $\begin{array}{l}\text { replication } \\
\text { to form identical } \\
\text { nucleic acid } \\
\text { molecules; } \\
\text { infectivity; }\end{array}$ & $\begin{array}{c}\text { replication } \\
\text { to form identical } \\
\text { ultramicrobes; } \\
\text { infectivity; } \\
\text { variation (mutation); }\end{array}$ & gene replication: & $\begin{array}{l}\text { spread of the } \\
\text { infectious } \\
\text { disease; }\end{array}$ \\
\hline $\begin{array}{l}\text { VEGE- } \\
\text { TATIVE } \\
\text { VIRUS }\end{array}$ & 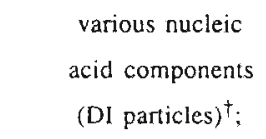 & $\begin{array}{l}\text { infectious } \\
\text { naked } \\
\text { nucleic acid; }\end{array}$ & $\begin{array}{l}\text { disappearance of virus } \\
\text { as infectious agent } \\
\text { (eclipse); }\end{array}$ & $\begin{array}{l}\text { s } \quad \text { genetic } \\
\text { recombination; }\end{array}$ & \\
\hline $\begin{array}{l}\text { PRO- } \\
\text { VIRUS }\end{array}$ & $\begin{array}{l}\text { infectious heredity } \\
\text { preservation of proper } \\
\text { of the lytic principle }\end{array}$ & $\begin{array}{l}\text { irties } \\
\text { les; }\end{array}$ & & $\begin{array}{l}\text { occurrence of } \\
\text { lysogeny: the } \\
\text { masking of virus } \\
\text { in cancer cells; }\end{array}$ & $\begin{array}{l}\text { latent virus; } \\
\text { occurrence of } \\
\text { lysogeny; }\end{array}$ \\
\hline
\end{tabular}

- The term 'phase of life' is placed here between quotation marks because the various phases in which the virus can exist do not necessarily occur in chronological order.

$\dagger$ For a definition of DI particles see section 2.7 of the present study.

\subsection{THE 'MODERN CONCEPT OF VIRUS' AND THE HISTORY OF VIROLOGY}

In this study, I started from the principle that the formation of consensus about the concept of virus could not be a consequence of the existence of a natural category of viruses. In fact the reverse was the case, i.e. the category of 'viruses' resulted from the formation of consensus. Therefore, the 'landmarks' in virus research cannot be seen as discoveries of the true nature of viruses but must be regarded as the recognition of a scientist's achievement by his peers and subsequently by 'historians'. This view of the process of discovery is presented by Augustine Brannigan as an 'attributional model' of discovery. ${ }^{49}$ In accepting this model, our

49. A. Brannigan, The social basis of scientific discoveries (Cambridge, 1981). For a 
attention is directed at the processes of construction in the historiography of a scientific domain. An analysis of "discovery accounts" with regard to the history of a discipline or specialty, presented by those involved or by historians, can reveal how these construction processes work, ${ }^{50}$

With the acceptation of the 'modern concept of virus', the history of virus research had to be rewritten because the work which had been done within the endogenous thought style now belonged to the history of virus research. After all, the research of scientists who worked within the endogenous thought style did not, as viewed from the exogenous thought style, belong to the domain of virus research. We have seen that Bordet took a firm stance regarding the nature of bacteriophage and denied the existence of a virus, while d'Hérelle rejected the research on lysogeny (see Chapter 4). Furthermore, we saw that Delbrück was not prepared to accept the results of the endogenous approach in phage research (see Chapter 5). On the other hand, Bawden and Pirie, who worked within the physiological research style, interpreted the cause of tobacco mosaic disease as a virus but were reticent about identifying the virus as an entity (see Chapter 2).

Before the 'modern concept of virus' was formulated, d'Hérelle was a 'Founding Father' of bacteriophage research for those who worked within the exogenous research styles. By contrast, the contributions of researchers, who studied lysogeny, e.g., Bordet, the Wollmans and Northrop, hardly won any esteem from the American branch of the 'Phage Group'. With the new theoretical network of the 'modern concept of virus', Lwoff acknowledged the important role of researchers who had studied lysogeny, especially Bordet, Bail and the Wollmans. ${ }^{51}$ In addition to the discussion of the role of historiography in the establishment and legitimation of molecular biology as a discipline see P. G. Abir-Am, "Essay review: how scientists view their heroes: some remarks on the mechanism of myth construction", Journal of the history of biology, xv (1982), 281-315; P. AbirAm, "Themes, genres and orders of legitimation in the consolidation of new scientific disciplines: deconstructing the historiography of molecular biology", History of science, xxiii (1985). 73-117.

50. See, for instance, S. Woolgar, "Writing an intellectual history of scientific development: the use of discovery accounts". Social studies of science, vi (1976), 395-422; T. van Helvoort, "Sociale constructie en deconstructie van ontdekkingen: flexibiliteit in 'discovery accounts" van bacteriofagie en lysogenie", Kennis en methode, x (1986), 312-30; 1. Löwy, "Variances in meaning in discovery accounts: the case of contemporary biology", Historical studies in the physical and biological sciences, xxi (1990), 87-121.

51. M. Delbrück, "Bacterial viruses or bacteriophages", Biological reviews, xxi (1946), 30-40; A. Lwoff, "Lysogeny", Bacteriological reviews, xvii (1953), 269-337, esp. pp. 273-80. Cf. Helvoort, op. cit. (ref. 50). 
recognition of the work which belonged to the endogenous thought style, another domain of research also came to be accepted as a precursor of modern virology. This was the work on oncogenic viruses.

In the United States, tumour viruses had been studied in particular by Peyton Rous and later by Richard E. Shope, while in England the work of William E. Gye was of major importance.52 Peyton Rous, who in 1911 isolated a 'filterable tumour agent' in fowl, was heavily criticized for his claim that he had isolated the cause of a cancer. The reception of a viral etiology of cancer in fowl was greatly hindered by the consensus that the cause of cancer was unknown. So, if an etiological agent was isolated it had to be concluded that the disease was not a cancer. In Rous' obituary, Christopher $\mathrm{H}$. Andrewes wrote that for many years "pathologists refused to consider that the discovery was relevant to the problem of cancer. One pathologist told Rous: 'Look here, young man, that can't be a cancer if you found its cause.' Some, like this pathologist, argued that the growths were not really cancers; others that the infective agent was not a virus or else that tumour cells had somehow penetrated the filters." 53 In 1926 Gye stated that the thesis that tumours were caused by microbes ran up against difficulties: “... opinion against a microbic cause of tumours is strong and few are prepared to accept for tumours conclusions which, on similar evidence, are unquestioned in other fields of medicine", 54 One problem in the studies of these cancers was that the 'virus' could often not be recovered, i.e., it could not be shown to be present as an infectious particle. The 'disappearance' of a tumour virus was also designated by terms like 'virus latency' and 'virus masking', but in the first half of the 20 th century this remained a mysterious phenomenon with an unknown mechanism. The concept of a 'provirus' was formulated on the basis of bacteriophage research, and this suggested a mechanism for 'virus masking' ${ }^{55}$

52. R. E. Shope, "Evolutionary episodes in the concept of viral oncogenesis", Perspectives in biology and medicine, ix (1966), 258-74.

53. C. H. Andrewes, "Francis Peyton Rous 1879-1970", Biographical memoirs of fellows of the Royal Society, xvii (1971), 643-62, esp. p. 644. Cf. P. Rous, "Transmission of a malignant new growth by means of a cell-free filtrate", Journal of the American Medical Association, Ivi (1911), 198; reprinted in JAMA ccl (1983), 1445-6; P. Rous and J. B. Murphy, "The nature of the filterable agent causing a sarcoma of the fowl", Journal of the American Medical Association, Iviii (1912), 1938.

54. W. E. Gye, "The Lloyd Roberts memorial lecture on the cancer problem", Lancet, ii (1926), 989-95, esp. p. 991.

55. R. E. Shope, "Are animal tumor viruses always virus-like?", Journal of general physiology, xlv (1962), 143-54. For the development of the concept of 'virus latency' into the 
In 1957 André Lwoff discussed the position of the tumour viruses in relation to his proposed definition of a virus. As an oncogenic virus incited a cell to unrestrained growth, this process could conflict with the definition of a virus as a (potential) pathogenic entity. However, Lwoff argued, the oncogenic viruses also satisfied his definition, because an infection with an oncogenic virus eventually led to the death of the host organism: "If one analyses the pathogenic action of oncogenic viruses one realizes that they modify the host cell which is a dependent part of an organism. In general terms, when considering the organism which transcends its individual interdependent parts, we have the right to say that oncogenic viruses are pathogenic." 56 With the 'modern concept of virus' it became possible to classify infectious agents of such varied constitution and with such varied behaviour as the bacterial, plant and animal viruses, as well as the oncogenic viruses, in one category.

The 'virological revolution' in the 1950s extended far beyond the domain of those virus diseases which were studied within the exogenous thought style of virus research. With the new consensus about the nature of viruses new relationships were created between the concepts of 'genes', 'viruses', 'cancer' and 'life'. In 1957 Wendell M. Stanley stated that these concepts had become linked, a statement which he sealed with a Declaration of dependence. The binding element in these concepts was, Stanley claimed, the structure of nucleic acid, whose clarification was thought to be of the greatest importance because "in nucleic acid structure we are dealing with life itself". 57

concept of 'provirus' see, for instance, the following literature: C. H. Andrewes, "Latent virus infections and their possible relevance to the cancer problem", Proceedings of the Royal Society of Medicine, xxxiii (1939), 75-86; H. Koprowski, "Latent or dormant viral infections", Annals of the New York Academy of Sciences, liv (1952), 963-76; D. L. Walker, R. P. Hanson and A. S. Evans (eds), Symposium on latency and masking in viral and rickettsial infections (Minneapolis, Minn., 1957); H. M. Temin, "The DNA provirus hypothesis: the establishment and implications of RNAdirected DNA synthesis", Science, cxcii (1976), 1075-80.

56. Lwoff, op. cit. (ref, 3), p. 252. It seems probable that the recognition of the work of Peyton Rous on cancer in fowl was greatly influenced by the acceptation of the 'modern concept of virus'. In 1966, Rous received the Nobel Prize for Physiology or Medicine, one year after Jacques Monod, Andre Lwoff and François Jacob received the same reward. With the discovery of 'reverse transcriptase' the 'provirus theory' of cancer would be definitively accepted, giving rise to a 'boom' in the research on oncogenic viruses. See K. E. Studer and D. E. Chubin, The cancer mission: social contexts of biomedical research (Beverly Hills, 1980).

57. W. M. Stanley, "Penrose memorial lecture: on the nature of viruses, cancer, genes, and life - a declaration of dependence", Proceedings of the American Philosophical Society, ci (1957), 317 - 


\subsection{CONCEPTUAL CONTINUTTY THROUGH DISCONTINUTTY}

The 'modern concept of virus', as formulated in the 1950 s, functioned as the consensus and rallying point on the basis of which virology as a scientific discipline became institutionalized in the 1960s and 1970s. From this newly achieved consensus the history of virus research was reinterpreted and new 'Founding Fathers' appeared on the stage. The result of this process can be found in chronological surveys such as Sally Hughes' Landmarks in viral research and Heinz Fraenkel-Conrat' \& Paul C. Kimball's Some highlights in the history of the science of virology. ${ }^{58}$

In the first list d'Hérelle is presented as the 'rediscoverer' of the virus of Twort, while the work of Bordet and Ciuca from 1921 is described as "one of the first descriptions of lysogeny". In the second chronology Stanley is staged as isolating "paracrystalline TMV" in 1935 and Bawden \& Pirie are said to have recognized the "nucleoprotein nature" of tobacco mosaic virus in 1937. These surveys of 'landmarks' form a confirmation of Waterson's claim that the history of virus research can be described as "the story of the progressive unveiling of the nature of the virus particle". 59 These reviews of discoveries of scientific 'facts', however, do not do justice to the complexity and dynamics which marked virus studies in the 20th century.

Virus research originated in experiments in which infectious agents appeared to be ultrafilterable, which presented an anomaly to the knowledge of bacteriology in the late 19 th century. On the basis of one or more of the criteria of filterability, invisibility and non-cultivability the concept of 'filterable virus' was formulated in the beginning of the 20th century, a concept which was used to classify agents which infected animals, plants or bacteria. Despite these anomalies, most virus researchers maintained the principal tenet of the bacteriological paradigm, viz., the microbial cause of infectious diseases. In the 1920s and 1930s the concept of 'filterable virus' became heavily criticized, in the first place because the nature of filterable agents infecting bacteria, plants or animals appeared to show great variety and secondly, because of the many controversies which arose about the nature of viruses.

In the case studies (see Chapters 2-6) I have shown that virus research was beset by many and protracted controversies in the first half of the 20th century and, furthermore, that various research styles can be identified which were anchored in

24.

58. Hughes, op. cit. (ref. 6), pp. 75-8; H. Fraenkel-Conrat and P. C. Kimball, Virology (Englewood-Cliffs, N. J., 1982), pp. 3-6.

59. Waterson, op. cit. (ref. 3), esp. p. xii. 
disciplinary contexts. These contexts were important because they provided analogies, models and metaphors as possible answers to crucial questions in virus research, such as What is the nature of a virus? and How does a virus multiply? For those researchers who worked from a bacteriological, genetic or evolutionary/ecological point of view, the analogy of a virus with a micro-organism was the most obvious one. According to this metaphor, a virus was conceived of as an ultramicrobe, and it was implicitly accepted that a virus multiplied by binary fission. The endogenous as well as the exogenous thought styles in virus research both had an answer to the above questions, inspired by a chemical context. The former assumed that a virus was a metabolic product of the host cell, while the latter interpreted a virus as an autonomous macromolecule. The chemical interpretation of the process of virus multiplication assumed an analogy with crystal growth or with autocatalytical processes, which were known from physiology. ${ }^{60}$

These metaphors did not only play a part at a theoretical level but also contributed to the decision what questions were to be asked, what experimental methods and research objects were to be used and what observations were relevant. Because analogies and models played an important part as heuristic principles, they were also of importance for the way virus research developed and consequently for the history of this discipline. ${ }^{61}$

In this chapter I have argued that after the deconstruction of the concept of the

60. It is interesting that the process of crystal growth still plays a role in virus research. In an attempt to give an explanation for the replication of the 'slow viruses', which are probably involved in degenerative diseases, D. Carleton Gajdusek and Clarence J. Gibbs, Jr. suggested the following possibility: "Analogies with defective or 'contaminated' seed crystals of simple nucleating molecules specifying the crystallization of their own distinct crystal structure come to mind." Quoted in A. G. Fettner, Viruses: agents of change (New York, 1990), p. 253. For an overview of the models which have been proposed for the 'multiplication' and action of the 'slow viruses' see, for instance, A. Scott, Pirates of the cell: the story of viruses from molecule to microbe (Oxford, 1987), pp. 188210.

61. Northrop argued that if the 'transforming principle' had been discovered before the viruses, the latter "would have been classified with the transforming principle, and it is doubtful if the parasite theory would have been accepted at any time." He arrived at this conclusion because of his view that viruses are "closely related to the transforming principle nucleic acids and not at all to cellular parasites." See J. H. Northrop, "Infectious macromolecules", Archives of biochemistry and biophysics, Supplement 1 (1962), 7-11, esp. p. 7. On the discovery, isolation and characterization of the 'transforming principle' see R. Olby, "Bacterial Transformation", in idem, The path to the double helix (London, 1974), pp. 169-79: M. McCarty. The transforming principle; discovering that genes are made of DNA (New York, 1986) 
'filterable virus', the notion of 'virus' could be maintained because at the level of the pathological effect of the virus, i.e., the virus disease of the host organism, similarities were perceived between the main groups of viruses. In other words, at that moment the concept of 'virus disease' formed the binding element between these virus groups. In this way conceptual continuity was maintained. In the 1950s the 'modern concept of virus' was formulated, which once again defined the unity of viruses on the basis of the nature of the virus particle. According to the 'modern concept of virus' the viruses - although they differed greatly in structure and composition - had some 'similarities' and 'dissimilarities' which allowed them to be classified in one category and at the same time differentiated them from other micro-organisms and from the genetic material of cells. ${ }^{62}$ To my knowledge, this dynamics of the concept of virus in definitions at various levels has not yet been described in the historiography of virus research, as it has been in scientific domains relating to virology, viz, the development of the cell theory and the history of genetics.

In his analysis of the history of the cell theory, William Bechtel concluded that periods of transformation as well as continuity could be observed in this development. He distinguished a number of phases in the history of cell theory in which "each stage contributed one piece to the modern view of the cell, but each stage also contained as major tenets ideas that later had to be rejected. Intuitively, this history [of cell theory] appears to be one of progress - using the current theory as the standard, we can judge each historical account as being more adequate than its predecessor." 63 Since rifts or transitions could be observed between the various stages, Bechtel claimed that the feeling of 'progress' in cell theory had to be explained. He concluded that the continuity between the different versions of the cell theory was not to be found in a "common essence" in these theories, and that every transition between subsequent theories had to be considered separately. The analyst has to describe how any theory arises by maintaining some aspects of the old theory and changing others. In his analysis of the development of the cell theory, Bechtel observed an "oscillation between reductionism and more holistic approaches" ${ }^{64}$

62. For a discussion of the role of 'similarities' and 'dissimilarities' in the formation of concepts see, for instance, T. S. Kuhn, "Second thoughts on paradigms", in idem, The essential tension: selected studies in scientific tradition and change (Chicago, 1977), pp. 293-319. Cf. B. Barnes, T. S. Kuhn and social science (London, 1982).

63. W. Bechtel, "The evolution of our understanding of the cell: a study in the dynamics of scientific progress", Studies in history and philosophy of science, xv (1984), 309-56, esp. p. 310.

64. Bechtel, op. cit. (ref. 63), pp. 349-56. 
Such a dynamics of shuttling between levels at which explanations were sought for a particular scientific domain, can also be discerned in the history of genetics. Raphael Falk describes the development of the concept of the gene as follows:

The genes were invented as intervening variables to explain the function of the laws of heredity at the level of (phenotypic) traits. As soon as they became hypothetical constructs it was only a matter of time before a material basis would be attached to these functional entities. Once the genes were accepted as material entities in their own right, it was possible to progress to the next level of analysis of the function of these entities. And when this was achieved, it was possible to ask again what structures would support these functions ... In a sense the cycle, or the turn of the spiral, is completed, we return from the Mullerian gene to that of Mendel and Johannsen: the phenotype defines the gene, rather than the gene defining the product (phenotype). ${ }^{65}$

The creation of continuity through the oscillation between reductionistic and holistic explanations in cell theories and in the definition of a gene as a material particle and defining it at the level of the phenotype, seems to parallel the way conceptual continuity was created in virus research. In the 20th century a virus was alternately defined on the basis of the virus particle, then on the basis of its pathological effect and then on the basis of the infectious entity. It is this alternation which made the feeling of progress with regard to the nature of viruses possible. ${ }^{66}$ I suggest that this oscillating mechanism can be described as the acquiring of conceptual continuity through discontinuity.

It will be clear that 'conceptual continuity through discontinuity' played a part in the controversies which were described in Chapters 2-6, and two examples may serve to clarify this. In the research on tobacco mosaic virus, when Stanley and Bawden \& Pirie disagreed about the nature of this virus, the controversy could arise because these opponents agreed that they were both studying tobacco mosaic disease. A second example concerns the controversy on the nature of bacteriophage between d'Hérelle

65. R. Falk, "What is a gene?", Studies in history and philosophy of science, xvii (1986), 133-73, esp. p. 153 and p. 169, respectively. Cf. Ph. Kitcher, "Genes", British journal for the philosophy of science, xxxiii (1982), 337-59 and Chapter 2 of the present study.

66. Recently, Evelyn Fox Keller has argued that multiple meanings can also be recognized in biological research on the concepts of 'directed mutation' and 'spontanous mutation': 'Typically, these multiple meanings are not separable in the discourses in which they occur, but coexistent and endemically oscillatory; in this way, they constitute effective reservoirs of meaning on which the overall arguments tacitly depend." See E. F. Keller, "Between language and science: the question of directed mutation in molecular genetics", Perspectives in biology and medicine, xxxv (1992), 292306. esp. p. 295. 
and Bordet. Again, this was a controversy over the nature of the agent (regarded as a bacterial virus or an endogenous product of the bacterium, respectively) but also over the experimental systems which each party claimed had to be used to obtain valid results. In spite of this, d'Hérelle and Bordet agreed that they were both studying the bacteriophage phenomenon, a consensus which was based upon agreement at the macroscopic level, i.e., a transmissible lysis of bacteria.

Starting from the idea of 'conceptual continuity through discontinuity' as a process by which incommensurability between different research styles can be overcome, it would seem useful to analyse the development of cancer research in the 20th century. In the development of this research domain endogenous and exogenous research styles also appear to have played a part, as is apparent from the following quotation from a book by William E. Gye and W. J. Purdy:

In the very broadest sense, theories as to the type of cause which is operative in cancer are but two in number. The one, which is inseparable from the cell theory, assumes that the cause of cancer is something which is operative only at the time when the primary cells of a cancer take on their malignant qualities, the disease afterwards progressing independently; the other assumes that cancer is due to the continuous action of some persisting cause, such for example as a living virus. It will be seen that the two theories are mutually incompatible. ${ }^{67}$

An analysis in terms of controversies, research styles and the formation of consensus by an oscillatory process of levels of explanation, seems to be an attractive approach in the study of reductionistic and holistic explanations in the history of cancer research. This field of research has yet to be subjected to historical and sociological analysis. 68

67. W. E. Gye and W. J. Purdy, The cause of cancer (London, 1931), p. 501. A useful summary of theories in the history of cancer research is presented in M. B. Shimkin, Contrary 10 nature; being an illustrated commentary on some persons and events of historical importance in the development of knowledge concerming ... cancer (Washington, D.C., 1977).

68. Lily Kay stated that the "story of the rise of cancer research - intellectual trends and institutional imperatives - awaits writing ...". See L. E. Kay. Molecules, cells, and life: an annotated bibliography of manuscript sources on physiology, biochemistry, and biophysics. 1900 1960, in the library of the American Philosophical Society (Philadelphia, 1989), pp. 30-1. 
' 


\section{Onderzoekstijlen in de Studie van Virussen in de Twintigste Eeuw: Controversen en de Vorming van Consensus}

\section{SAMENVATTING}

In de jaren 1950 raakte de virologie geinstitutionaliseerd als een onafhankelijke wetenschappelijke discipline. Eén van de fundamenten van dit proces was de nieuwe definitie van virussen als infectieuze agentia bestaande uit één soort nucleïnezuur (DNA óf RNA) dat door eiwit wordt omgeven. Naast zijn structuur maakt ook de wijze waarop een virus zich reproduceert deel uit van het 'moderne virusconcept'. Tijdens zijn vermenigvuldiging gaat een virus door een eclips: het 'verdwijnt' als een infectieuze entiteit en wordt gereproduceerd in de vorm van zijn genetisch materiaal. Daarvoor is het virus afhankelijk van het metabolisme van de gastheercel die het infecteert. De eclips van een virus tijdens zijn vermenigvuldiging vormt een kenmerkend onderscheid met de wijze van vermenigvuldiging van een bacterie welke tijdens dit proces eerst in omvang toeneemt waarna insnoering plaatsvindt en er twee dochtercellen ontstaan. Een bacterie vermenigvuldigt zich via binaire deling. Het 'moderne virusconcept' vormde een rationale om agentia in één categorie onder te brengen ongeacht of ze voor hun vermenigvuldiging afhankelijk waren van een dierlijke cel, een plantecel, dan wel een bacterie.

Het 'moderne virusconcept' verving een definitie van virussen die op de drempel van de 19 e naar de 20 e eeuw was geformuleerd. Toen werd een virus gedefinieerd als een infectieus agens dat filtreerbaar is door een filter van aardewerk waarvan men aannam dat deze voor bacteriën ondoorlaatbaar was. Bovendien konden de meeste bacteriën met een lichtmicroscoop worden waargenomen hetgeen met de filtreerbare virussen niet het geval was: deze waren onzichtbaar. Met betrekking tot de afhankelijkheid van een filtreerbaar virus van een levende gastheercel heerste er onder de wetenschappers verdeeldheid. Sommigen zagen deze afhankelijkheid als een fundamenteel kenmerk terwijl anderen van mening waren dat wanneer men meer wist over de voedingseisen van de filtreerbare virussen het mogelijk zou moeten zijn om ze op een kunstmatige voedingsbodem zonder cellen (in vitro) te kweken.

De aanleiding voor mijn studie was de constatering dat er zich in de eerste helft van de $20 \mathrm{e}$ eeuw tal van heftige en langdurige controversen hebben afgespeeld over de aard van de (filtreerbare) virussen. Aangezien in de jaren 1980 het zogeheten weten- 
schapsonderzoek met name was geïnteresseerd in de wijze waarop 'wetenschappelijke feiten' tot stand komen was een analyse van controversen in het virusonderzoek en de vorming van consensus in de jaren 1950 bijzonder relevant. Daartoe werd een analyse gemaakt van de ontwikkeling van het onderzoek naar het agens dat bij de tabaksplant mozaijekziekte veroorzaakt, naar het etiologische agens van influenza bij de mens en naar het verschijnsel bacteriofagie (een 'in serie overdraagbaar' verschijnsel waarbij een bacteriekweek door een filtreerbaar agens wordt gelyseerd).

Mijn studie is ingegeven door de vraag waardoor in de eerste helft van de $20 \mathrm{e}$ eeuw de controversen in het virusonderzoek ontstonden en waarom zij zo lang voortduurden. De these die in deze studie wordt verdedigd is dat dit een gevolg was van het feit dat de verschillende onderzoekers in een controverse hun onderzoek uitvoerden binnen een onderzoekstijl welke voor hun benadering kenmerkend was. Mijn studie toont aan dat de positie die een onderzoeker innam in sterke mate werd geïnspireerd door de disciplinaire achtergrond van waaruit hij te werk ging. Met het begrip onderzoekstijl wordt niet een methodologische werkwijze bedoeld maar het geheel van doelstellingen, relevant geachte analogieën, modellen, experimentele methoden en technieken, alsmede een 'commitment' aan wat als een valide resultaat geldt. De lange duur van sommige controversen tot aan enkele tientallen jaren toe kan dan verklaard worden vanuit het holistische karakter van de desbetreffende onderzoekstijlen waarbinnen de onderzoekers werkten. Aangezien de door mij geidentificeerde onderzoekstijlen in belangrijke mate vanuit een disciplinaire achtergrond geïnspireerd blijken vertoont een onderzoekstijl dan ook een sterke gelijkenis met Thomas Kuhns definitie van een disciplinaire matrix.

Deze studie is een historische beschrijving en analyse van de componenten waaruit de onderzoekstijlen in het virusonderzoek uit de 20e eeuw zijn opgebouwd. Het veelvuldig aanwezig zijn van controversen dwong de betrokken wetenschappers om de eigen positie en die van hun opponent expliciet te formuleren. Dit maakt deze onderzoekstijlen gemakkelijk toegankelijk voor analyse. Doordat meerdere controversen zijn onderzocht (zowel over een virus dat de mens als gastheer heeft als over een plantevirus en een bacterievirus) kwam naar voren dat in het virusonderzoek in de 20 e eeuw de tegenstelling exogeen versus endogeen vaak een thema was waartegen de discussie over de aard van virussen zich afspeelde. Een resultaat van mijn studie is dan ook de these dat de geschiedenis van het virusonderzoek wordt gekenmerkt door een tegenstelling tussen een exogene interpretatie en een endogene interpretatie van virussen. Hierbij moet echter steeds in gedachten gehouden worden dat de theoretische 
interpretaties niet los gezien kunnen worden van de experimentele methoden en technieken alsmede van de bestudeerde objecten. Het is daarom meer correct om te spreken van een tegenstelling tussen exogene en endogene onderzoekstijlen in het virusonderzoek in de $20 \mathrm{e}$ eeuw.

In Hoofdstuk 2 wordt het onderzoek beschreven naar het agens dat in tabaksplanten mozaìekziekte veroorzaakt. Het was het eerste infectieuze agens waarvan, aan het eind van de $19 \mathrm{e}$ eeuw, de filtreerbaarheid werd geconstateerd. In de eerste decennia van de 20 e eeuw werd tabaksmozaïekvirus (TMV) binnen een bacteriologische dan wel binnen een chemische context geplaatst. In het eerste geval werd TMV beschouwd als een levende ultramicrobe (een heel kleine bacterie) terwijl in het tweede geval werd verondersteld dat het chemisch was en dus levenloos van aard. Bij de chemische interpretatie werd 'groei' van het virus tijdens het infectieproces verklaard middels een analogie met autokatalyse.

In 1935 verscheen er een artikel van Wendell M. Stanley waarin hij stelde TMV gekristalliseerd te hebben en waarbij hij het identificeerde als een globuline (proteine), De zuivering van TMV door F. C. Bawden en N. W. Pirie als een parakristallijn produkt en de identificatie als een nucleoproteine (nucleïnezuur + eiwit) zouden aanleiding geven tot een controverse tussen beide partijen waarbij een prioriteitstrijd een zekere rol speelde. Mijn studie toont dat de controverse over welk object als tabaksmozaïekvirus gedefinieerd diende te worden echter zeker zo belangrijk was. Gedurende meer dan twee decennia zou de fysisch-chemische benadering van Stanley en zijn medewerkers botsen met de fysiologische (biochemische) benadering van het probleem van virusziekten bij planten volgens welke Bawden en Pirie werkten.

Binnen de fysisch-chemische onderzoekstijl werd tabaksmozaiekvirus beschouwd als een exogeen en autonoom macromolekuul. Daarbij werd virusvermenigvuldiging verklaard aan de hand van analogieën uit de domeinen van de chemie en de fysische chemie zoals kristalgroei en autokatalyse. Binnen de biochemische benadering werd TMV gezien als het resultaat van een ontsporing van de eiwitproduktie, anders gezegd, als een produkt van de gastheercel. Later werd dit geherformuleerd in termen van de produktie van nucleoproteinen.

Het 'moderne virusconcept' omvat zowel elementen uit de fysisch-chemische onderzoekstijl als uit de biochemische benadering. Het genetisch materiaal van TMV (RNA) kan als een macromolekuul worden opgevat terwijl het nucleïnezuur en eiwit van het virusnageslacht door het metabole apparaat van de gastheercel wordt geleverd. Bovendien werd in de jaren 1960 en 1970 aangevoerd dat het proces van virusinfectie gecompliceerder is dan de vermenigvuldiging van een autonoom macromolekuul: de 
aan- of afwezigheid van zogeheten 'defective interfering particles' (DI-deeltjes) bleek sterk van invloed op het verloop van de virusinfectie. Het complexe karakter van een virusinfectie was steeds één van de belangrijkste stellingen van de biochemische benadering van Bawden en Pirie geweest.

In Hoofdstuk 3 wordt het onderzoek beschreven naar het etiologische agens van griep bij de mens (influenza). In deze gevalstudie wordt geconcludeerd dat het onderzoek naar dit agens in sterke mate werd beïnvloed door de analogie die werd verondersteld met bacteriën (virus als ultramicrobe). Het lijkt waarschijnlijk dat een dergelijk bacteriologisch paradigma van grote invloed is geweest op de studie van vele soorten filtreerbare virussen die mens of dier als gastheer hebben.

Het bacteriologische paradigma deed op verschillende niveaus zijn invloed op het influenza-onderzoek gelden. In de eerste plaats met betrekking tot het opsporen en isoleren van een etiologisch agens van de ziekte. Daarbij maakten onderzoekers gebruik van de 'Postulaten van Koch' die zo succesvol waren geweest bij het duiden van een bacterie als oorzaak van een bepaalde infectieziekte bij mens of dier. Resumerend stellen de 'Postulaten van Koch': (a) wanneer een bepaalde infectieziekte wordt gediagnostiseerd dan moet het infectieuze agens aangetroffen worden; (b) het agens moet geisoleerd kunnen worden en in vitro gekweekt; (c) uit een dier dat met dit isolaat geïnfecteerd wordt moet op zijn beurt het agens weer geïsoleerd kunnen worden. Aan de hand van deze principes werd in 1892 door Richard Pfeiffer gesteld dat hij de bacteriële oorzaak van influenza bij de mens had geïsoleerd. Maar tijdens de pandemie van 1918 werd geconcludeerd dat deze bacterie, Haemophilus influenzae, niet de oorzaak van influenza kon zijn.

Mijn these is dat, toen in 1933 een filtreerbaar agens als verwekker van influenza bij de mens werd aangeduid, men binnen het bacteriologische paradigma bleef werken. De kenmerken van dit paradigma waren: (i) het aanhangen van de kiemtheorie: er is een causale relatie tussen infectieus agens en infectieziekte; (ii) men hanteerde een epidemiologisch model voor de verspreiding van influenzavirus; (iii) het opsporen van een etiologisch agens volgens de 'Postulaten van Koch'; (iv) de identificatie van influenzavirus op het effect-niveau van het virus; (v) evolutionair gezien beschouwde men virussen als gedegenereerde bacteriën waaruit de consequentie werd getrokken dat ze zich volgens het schema van binaire deling vermenigvuldigden.

Pas aan het eind van de jaren 1940 werd voor influenzavirus afstand genomen van het bacteriologische paradigma. Daarbij speelden twee ontwikkelingen een cruciale rol. Ten eerste werd uit vaccinatie-studies geconcludeerd dat influenzavirus immuno- 
logisch erg variabel is en dus instabiel. Ten tweede, in 1948 concludeerde Leslie Hoyle dat influenzavirus in twee vormen vóórkomt: buiten de cel als infectieus virus maar intracellulair (tijdens virusreproductie) als niet-infectieus. Hiermee was het concept geformuleerd van een eclips tijdens virusvermenigvuldiging en in de eerste helft van de jaren 1950 zou dit mechanisme geaccepteerd raken. Daarmee was voor virussen die een mens of een dier infecteren definitief afstand genomen van het bacteriologische paradigma van waaruit het virusonderzoek was ontstaan.

De drie volgende hoofdstukken betreffen onderzoek naar de aard van het bacteriofaag-fenomeen (bacteriofagie). Dit is het lyseren (oplossen) van bacteriën onder invloed van een filtreerbaar agens dat hierbij in kwantiteit toeneemt: het verschijnsel is dus, van bacteriekweek naar bacteriekweek, in serie overdraagbaar. Degene die dit principe in 1917 de naam bacteriofaag gaf, Félix d'Hérelle, verdedigde dat het hierbij om een virus van de bacterie zou gaan waarmee hij een exogeen, autonoom en levend agens bedoelde. Daartegenover kwam de opvatting te staan dat het principe als een product van de bacterie opgevat diende te worden: een endogene interpretatie. Uit een drietal gevalstudies die zich elk tijdens een andere periode afspeelden wordt geconcludeerd dat de tegenstelling exogeen versus endogeen gedurende meer dan drie decennia een belangrijke rol speelde in het bacteriofaag-onderzoek. In deze controversen stond het verschijnsel lysogenie centraal. Lysogenie is het verschijnsel dat uit een zogeheten lysogene bacterie de bacteriofaag 'spontaan' kan ontstaan. De interpretatie van dit fenomeen vormde één van de kernpunten in de controversen over de aard van de bacteriofaag. In de jaren 1950 zou de consensus ontstaan dat een lysogene bacterie de bacteriofaag (faag) in de vorm van een Anlage (de 'probacteriofaag' of 'profaag') draagt, welke eigenschap op de dochtercellen van de bacterie wordt overgedragen.

Er zijn een drietal redenen om de geschiedenis van het bacteriofaag-onderzoek zo uitgebreid te bespreken: (i) het bacteriofaag-onderzoek heeft het virusconcept in sterke mate beïnvloed: was er eerst nagenoeg overeenstemming over dat filtreerbare virussen konden worden opgevat als ultramicroben, na de ontdekking van de bacteriofaag nam het aantal onderzoekers dat veronderstelde dat een virus als een produkt van de gastheercel beschouwd moest worden sterk toe; (ii) er heersten veelvuldige en langdurige controversen in het bacteriofaag-onderzoek waardoor de onderzoekstijlen gedetailleerd beschreven en geanalyseerd kunnen worden; (iii) het 'moderne virusconcept' zoals dat in de jaren 1950 werd geformuleerd was in belangrijke mate gebaseerd op de resultaten van het bacteriofaag-onderzoek.

In Hoofdstuk 4 wordt de controverse beschreven tussen Félix d'Hérelle en Jules 
Bordet over het bacteriofaag-fenomeen die zich in de jaren 1920 en de vroege jaren 1930 heeft afgespeeld. Uit de analyse blijkt dat het werk van d'Hérelle geduid kan worden als een bacteriologische onderzoekstijl. Kenmerkende elementen uit deze onderzoekstijl zijn: - bacteriofagie is een infectieziekte van de bacterie; - de bacteriofaag is een levend en autonoom agens; - er is speciale aandacht voor kwalitatieve aspecten van bacteriofaag en bacterie; - lysogenie is een artefact: een lysogene bacterie moest opgevat worden als een mengsel van bacteriofaag en bacterie in de bacteriologische zin van het woord. Voor d'Hérelle was het werk van Louis Pasteur aan infectieziekten een belangrijke inspiratiebron.

Het werk van Jules Bordet is te kenmerken als een fysiologische onderzoekstijl waarin elementen zijn te herkennen van Bordets eerdere werk binnen de immunologie en serologie. De kenmerken van diens onderzoekstijl zijn: - de bacteriofaag is niet autonoom maar ontstaat endogeen; - de bacteriofaag is niet complex maar eenvoudig; - het bacteriofaag-fenomeen is afhankelijk van de eigenschappen van de bacterie; bacteriofagie is gerelateerd aan andere lytische fenomenen welke uit de bacteriologie bekend zijn; - lysogenie is een valide fenomeen. Tussen d'Hérelle en Bordet is over bacteriofagie nimmer consensus ontstaan.

In Hoofdstuk 5 wordt de controverse geanalyseerd over de aard van het bacteriofaag-fenomeen tussen John H. Northrop en diens medewerker Albert P. Krueger aan de ene kant en Max Delbrück en Salvador E. Luria aan de andere. De controverse die zich in de jaren 1940 afspeelde ging met name over de vraag hoe de bacteriofaag zich vermenigvuldigt (groeit) waarbij de rol van het oplossen (lyseren) van de bacterie centraal stond. Northrop en Krueger formuleerden het probleem van de vorming van de bacteriofaag als de algemene vraagstelling hoe eiwit gesynthetiseerd wordt. Voor Delbrück was de inzet van de discussie de rol van lysis van de bacterie bij de produktie van bacteriofaag. In dit hoofdstuk wordt beschreven uit welke elementen de respectievelijke onderzoekstijlen van de opponenten waren opgebouwd. Er wordt beargumenteerd dat de controverse in stand werd gehouden doordat elke partij vasthield aan eigen specifieke analogieën, methoden \& technieken en experimentele systemen. Met betrekking tot de discussie omtrent lysogenie is dit bijzonder duidelijk zichtbaar: Delbrück twijfelde ten zeerste aan de validiteit van dit fenomeen terwijl de produktie van bactericfaag door lysogene bacteriën de kern van Northrops argumentatie vormde. Geconcludeerd wordt dat in de controverse tussen Delbrück en Northrop een bacteriologisch/genetische onderzoekstijl tegenover een fysiologische onderzoekstijl stond. 
Uit de hoofdstukken 4 en 5 wordt de conlusie getrokken dat er in het bacteriofaagonderzoek gedurende lange tijd een tegenstelling heeft bestaan tussen exogene en endogene onderzoekstijlen. De disciplinaire achtergrond van de betrokken onderzoeker speelde een belangrijke rol in de wijze waarop het probleem van de aard van de bacteriofaag werd geformuleerd. Belangrijk is vast te stellen dat deze disciplinaire achtergrond of context echter niet alleen van invloed was op de interpretatie van de experimenten maar ook op de wijze waarop het onderzoeksprobleem werd aangepakt, op de definitie van het object van studie, op de gehanteerde experimentele methoden alsmede de 'commitments' met betrekking tot de vraag wat als een relevant resultaat geldt.

In Hoofdstuk 6 wordt onderzoek naar het bacteriofaag-fenomeen beschreven van onderzoekers die probeerden om de tegenstelling exogeen versus endogeen te overbruggen. Macfarlane Burnet hanteerde een dualistische interpretatie van de bacteriofaag: enerzijds als een functie van de bacterie terwijl hij anderzijds de faag beschouwde als een autonome entiteit. Daarbij baseerde hij zich voornamelijk op evolutionaire en ecologische overwegingen waarbij begrippen zoals parasitisme en symbiose een centrale rol speelden. Het werk van Eugène en Elisabeth Wollman aan lysogene bacteriën is een tweede voorbeeld waarin werd geprobeerd om een exogene opvatting over de bacteriofaag (als een complexe entiteit) te verbinden met een endogene opvatting. De Wollmans stelden dat dit mogelijk was wanneer de bacteriofaag werd opgevat als een erfelijke factor (facteur héréditaire).

Het zou tenslotte André Lwoff zijn die met zijn experimenten met geïsoleerde lysogene bacteriën (micromanipulatie) de wetenschappelijke gemeenschap wist te overtuigen dat lysogenie een valide fenomeen vormde. Bij zijn definitie van lysogenie maakte Lwoff een onderscheid tussen een exogeen bacteriofaag-deeltje, de zich vermenigvuldigende (vegetatieve) bacteriofaag en de profaag of probacteriofaag (voor een karakterisering van deze drie vormen in termen van structuur en functie zie tabel 6.1, p. 168). Met de formulering van het 'moderne faagconcept' werd een onderscheid aangebracht tussen bacterie of cel, bacteriofaag (bacterievirus) en gen. In de vorm van de profaag is de bacteriofaag een endogene functie van de bacterie. Dit model voor de profaag werd de analogie voor het concept van een 'latent virus' dat van groot belang zou zijn bij de acceptatie van een virale etiologie van kanker. Hiermee kon het 'verdwijnen' van een oncogeen virus bij celtransformatie verklaard worden.

Ondanks dat de profaag werd gedefinieerd als een endogene functie van de bacterie werd nog steeds verondersteld dat de bacteriofaag autonoom was. Deze opvatting moest worden losgelaten nadat werd geconcludeerd dat sommige erfelijke eigen- 
schappen van de bacterie permanent een wijziging ondergingen wanneer deze in het bezit van een probacteriofaag was (lysogene bacterie). Er werd geconcludeerd dat er klaarblijkelijk een interactie plaatsvindt tussen de genetische informatie van de probacteriofaag en het genetisch materiaal van de bacterie. Daarmee was de tegenstelling exogeen versus endogeen opgeheven.

De dynamiek die de definitie van een virus in de jaren 1950 en 1960 onderging is te illustreren aan de hand van de virusdefinities die door Salvador E. Luria werden geformuleerd. In 1950 definieerde Luria een virusinfectie als het resultaat van de vermenigvuldiging van een autonome (exogene), submicroscopische eenheid die alleen in een gastheercel in staat is om zich te vermenigvuldigen. In 1959 definieerde Luria een virusinfectie als genetisch parasitisme van de gastheercel door het virus terwijl drie jaar later een virus door hem werd omschreven als infectieuze erfelijkheid.

De positieve heuristiek van het 'moderne virusconcept' betreft een omschrijving van de chemische opbouw (structuur) van virussen en de wijze van hun vermenigvuldiging. Een negatieve heuristiek betrof het verwijderen uit de categorie virussen van intracellulair vermenigvuldigende agentia zoals Rickettsiae, Chlamydiae en PPLOorganismen die zich volgens een proces van binaire deling vermenigvuldigen.

In Hoofdstuk 7 worden de elementen van de onderzoekstijlen van de verschillende gevalstudies bij elkaar gebracht. De geïdentificeerde onderzoekstijlen zijn niet slechts theoretische interpretaties maar hangen nauw samen met welke experimenten worden uitgevoerd en welke methoden \& technieken gehanteerd worden. Tevens zijn ze afhankelijk van welke analogieën en metaforen relevant worden geacht (zie bijv. tabel 7.1, p. 181).

In het onderzoek naar tabaksmozaïekziekte en bacteriofagie kunnen exogene en endogene onderzoekstijlen geidentificeerd worden. Daarentegen zijn in het onderzoek naar influenza bij de mens alleen exogene onderzoekstijlen aangetroffen. De exogene onderzoekstijlen vallen onder te verdelen in een bacteriologische, een fysischchemische, een genetische en een ecologisch/evolutionaire benadering (zie tabel 7.2, p. 182). Uit deze opsomming blijkt het belang van de disciplinaire achtergrond van de betrokken onderzoeker van waaruit deze het onderzoek verrichtte. De belangrijkste elementen uit de exogene en endogene onderzoekstijlen in het virusonderzoek in de 20 eeuw zijn in tabel 7.4 (p. 192) samengebracht.

Wanneer deze opsplitsing van het virusonderzoek in exogene en endogene onderzoekstijlen wordt aanvaard heeft dit belangrijke consequenties voor de geschiedenis van het virusconcept. Volgens de standaard-historiografie van de virologie heeft er een geleidelijke en continue overgang plaatsgevonden van het 
concept van het 'filtreerbaar virus' naar het 'moderne virusconcept'. De geschiedenis van de virologie is omschreven als 'the story of the progressive unveiling of the nature of the virus particle'. Wanneer echter de conclusie van mijn studie dat elke onderzoekstijl zijn eigen object van studie definieert — niet noodzakelijkerwijs overeenkomend met het object van een andere onderzoekstij] - wordt geaccepteerd dan dient de genoemde vorm van continuiteit ter discussie gesteld te worden.

In Hoofdstuk 7 wordt een eerste aanzet gegeven voor een antwoord op de vraag hoe dit probleem van conceptuele continuiteit in de definitie van virussen verklaard zou kunnen worden. Ofschoon in de eerste decennia van de $20 \mathrm{e}$ eeuw filtreerbare virussen op basis van filtreerbaarheid en onzichtbaarheid werden gedefinieerd bleef dit niet het enige criterium. Naast de afhankelijkheid van een virus van een gastheercel voor zijn vermenigvuldiging (niet-kweekbaarheid op een inerte voedingsbodem) speelden ook andere eigenschappen van virussen een rol bij de definitie van de categorie 'virussen'. Niet alleen de grootte van een virus vormde een criterium maar ook het virus-effect, dat wil zeggen de virusziekte. Zo werd de relevantie van de categorie 'virussen' ook bediscussieerd in termen van het pathologisch effect van een virus zoals zichtbaar in zijn epidemiologische en ecologische eigenschappen. Ook het fenomeen van virale interferentie (de gelijktijdige infectie van een gastheer of gastheercel door twee typen virussen) was een manier om de relatie tussen bacterievirussen, plantevirussen en virussen die dieren infecteren te evalueren.

De conceptuele continuiteit tussen het concept van het 'filtreerbaar virus' en de virusdefinitie volgens het 'moderne virusconcept' is dus niet uitsluitend gelegen in de virusdeeltjes (virions) zelf. Continuitteit werd ook gecreëerd door te zoeken naar overeenkomsten en verschillen op het effect-niveau van de 'onzichtbare' agentia. Een dergelijk proces waarbij conceptuele continuiteit werd verkregen door te switchen van microscopisch niveau (filtreerbaarheid, onzichtbaarheid) naar macroscopisch niveau (effect-niveau) vertoont sterke gelijkenis met de dynamiek van het genconcept. Ook het afwisselen van holistische en reductionistische verklaringen binnen de theorieën over de 'cel' zou hiertoe kunnen behoren. Dit zijn aanwijzingen voor een centraal mechanisme waarmee in de $19 \mathrm{e}$ en $20 \mathrm{e}$ eeuw in de biomedische wetenschappen conceptuele continuïteit werd gecreëerd. 



\section{Curriculum Vitae}

Ton van Helvoort was born on 10 August 1954 in Eindhoven, The Netherlands

1966 - 1971 Secondary education: 'Hogereburgerschool-B' (HBS-B), Eindhoven

1971 - 1975 B. Sc.: Chemistry with biology, Catholic University, Nijmegen

1975 - 1979 M. Sc.: Biochemistry with inorganic chemistry, Catholic University, Nijmegen

1982 - 1983 Scientific assistant on the project 'History of molecular biology', working party on History of Chemistry, Catholic University, Nijmegen

1984 - 1985 Part-time assistant (0.6) on the project 'Science shop and environmental issues', Catholic University, Nijmegen

1986 - 1990 Part-time scientific researcher (0.5) on the project 'History of virus studies in the 20th century', part of the research project Science studies of health sciences and health technology, University of Limburg, Maastricht

1986 Free-lance scientific writer for pharmaceutical and chemical - present industries. 
